\title{
ECONOMIC METRICS FOR THE PRIORITIZATION OF \\ CRITICAL FREIGHT INFRASTRUCTURE NEEDS
}

\author{
A Dissertation \\ Presented to \\ the faculty of the School of Engineering and Applied Science \\ University of Virginia
}

\author{
in Partial Fulfillment \\ of the requirements for the degree \\ Doctor of Philosophy, Civil Engineering
}

by

Jeremy L. Schroeder

May 2013 


\author{
APPROVAL SHEET \\ The dissertation \\ is submitted in partial fulfillment of the requirements \\ for the degree of \\ Doctor of Philosophy, Civil Engineering \\ Jeremy L. Schroeder, Author
}

This dissertation has been read and approved by the examining committee:

Dr. Michael J. Demetsky, Advisor

Civil and Environmental Engineering

Dr. Brian L. Smith, Committee Chairperson

Civil and Environmental Engineering

Dr. Steven B. Chase, Committee Member

Civil and Environmental Engineering

Dr. John S. Miller, Committee Member

Virginia Center for Transportation

Innovation and Research

Dr. James H. Lambert, Committee Member

Systems and Information Engineering

Accepted for the School of Engineering and Applied Science:

Dr. James H. Aylor, Dean

School of Engineering and Applied Science

May 2013 


\section{ACKNOWLEDGEMENTS}

I would like to thank my advisor Michael J. Demetsky and committee members John Miller, Brian Smith, Steven Chase, and James Lambert for all of their helpful guidance, feedback, and input to this research. I would also like to thank all of my family and friends who have supported me by providing encouragement and believing in me. 


\section{TABLE OF CONTENTS}

\section{ACKNOWLEDGEMENTS ........................................................................................}

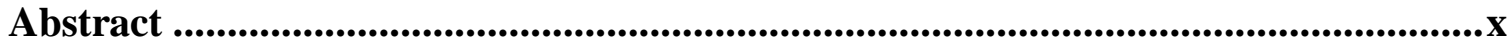

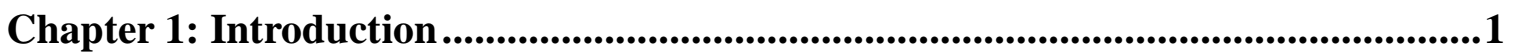

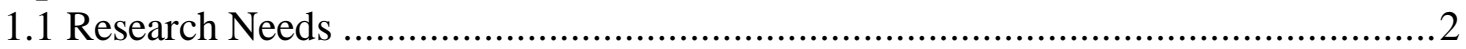

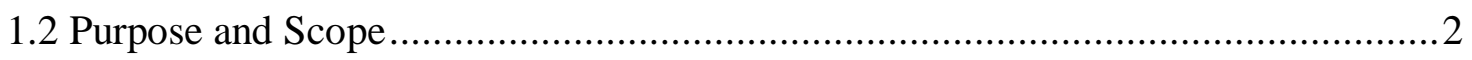

Chapter 2: Research Plan ...................................................................................................4

Chapter 3: Task 1 - Literature Review ........................................................................8

3.1 Infrastructure Improvement Prioritization State of Practice …….......................... 8

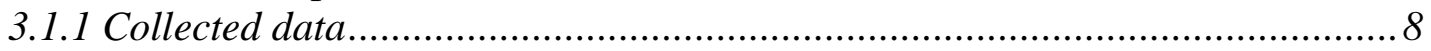

3.1.2 Existing Prioritization Frameworks ……………................................... 10

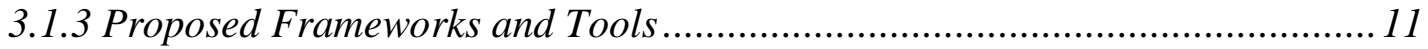

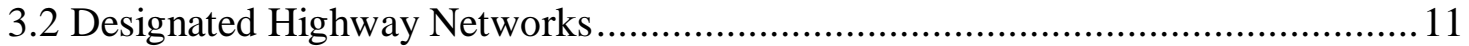

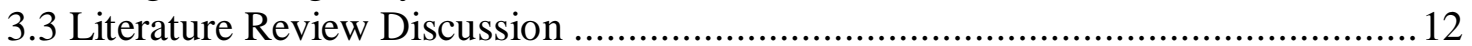

Chapter 4: Task 2 - Investigate Performance Measures .............................................13

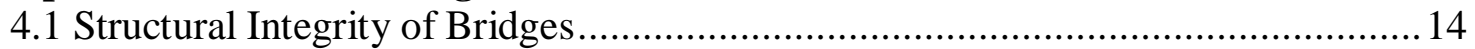

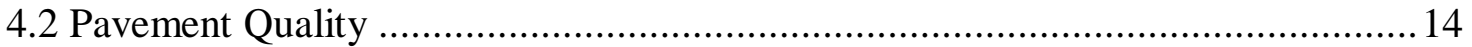

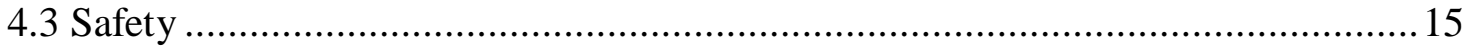

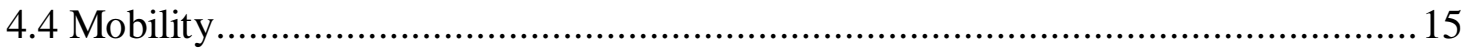

Chapter 5: Task 3 - Measuring Highway Economic Importance ................................17

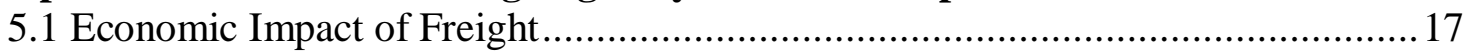

5.2 Performance Measures of Economic Impacts of Transportation ........................... 18

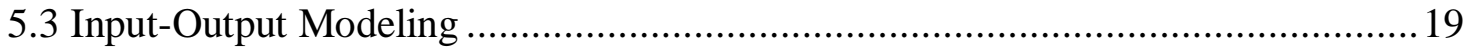

5.4 Measuring Highway Economic Importance Discussion.....................................20

Chapter 6: Task 4 - Link Economic Importance and Freight Highway

Infrastructure Needs ...............................................................................................23

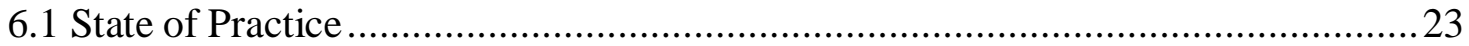

6.2 Developing a Decision Model to Prioritize Freight Highway Infrastructure Needs

Chapter 7: Task 5 - Conduct concept demonstrations............................................26

7.1 Developing the Inoperability Input-Output Model...........................................26

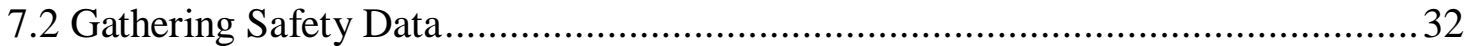

7.3 Concept Demonstration \#1: U.S. 460 Expressway - Hampton Roads to Petersburg,

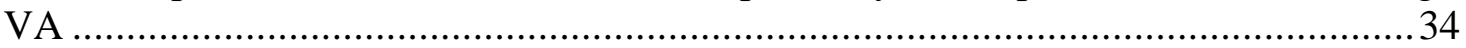

7.3.1 Calculating U.S. 460 Economic Importance .................................................36

7.3.2 Calculating U.S. 460 Excess Trucking Costs ................................................... 39

7.3.3 Calculating U.S. 460 Economic Hindrance ……..........................................4. 42

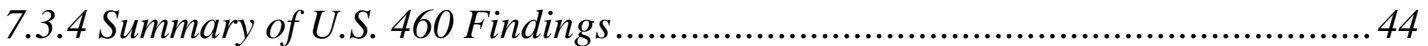

7.4 Concept Demonstration \#2: U.S. 29 Bypass - Charlottesville / Albemarle County,

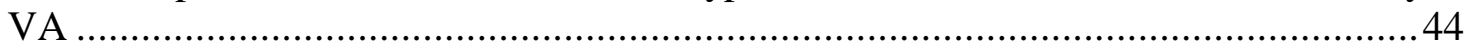

7.4.1 Calculating U.S. 29 Economic Importance …………..................................4 46

7.4.2 Calculating U.S. 29 Excess Trucking Costs ..................................................4 
7.4.3 Calculating U.S. 29 Economic Hindrance ............................................... 51

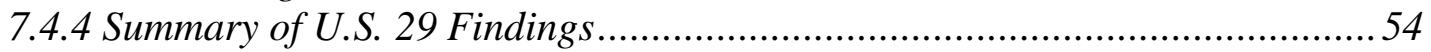

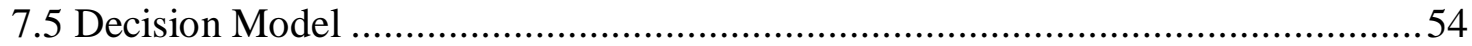

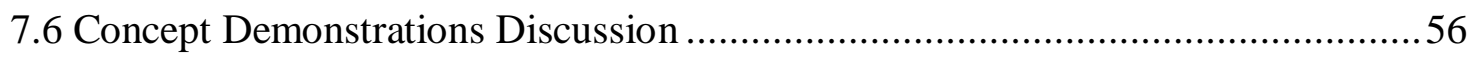

Chapter 8: Task 6 - Implementation, Disscussion, Conclusions, and

Recommendations ..........................................................................................57

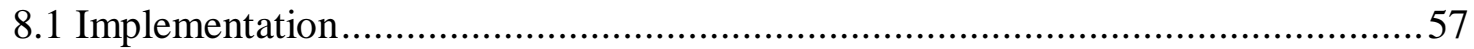

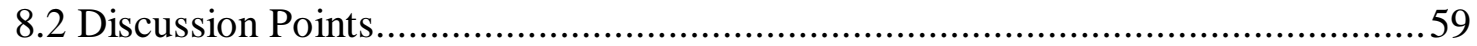

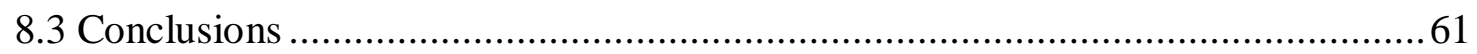

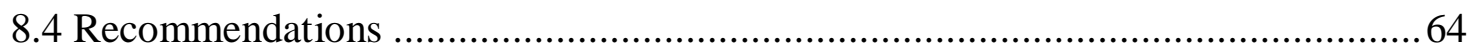

References...........................................................................................................65

Appendix A - Intra-statewide Sample Demonstration of Proposed Economic Metric

Development Methodology Using 12 Commodities in Virginia..................A-1

Appendix B - Input-Output Data Tables Used in Concept Demonstrations.........B-1

Appendix C - Crash Data Used in Concept Demonstrations......................... 


\section{LIST OF FIGURES}

Figure 1. Flow of Inputs and Outputs of Proposed Methodology ………….....................5

Figure 2. Proposed setup for Freight Infrastructure Prioritization Methodology ...............6

Figure 3. Example of integrating new metrics into an existing asset management system

Figure 4. Steps for development of inoperability input-output model and calculation of impacts of an industry disruption (e.g., trucking) to other industrial sectors

Figure 5. Map of eastern Virginia showing U.S. 460 (existing and proposed "new" in red) and other major routes in the region

Figure 6. Freight Analysis Framework region groupings for origin-destination route assignment designation to/from the Hampton Roads area given available, selected routes

Figure 7. Map of U.S. 29 corridor with proposed bypass and other major alternate routes

Figure 8. Freight Analysis Framework region groupings for origin-destination route assignment designation through central Virginia .

Figure A-1. Example vectors and Leontif coefficient matrix of the I-O model..........A-2

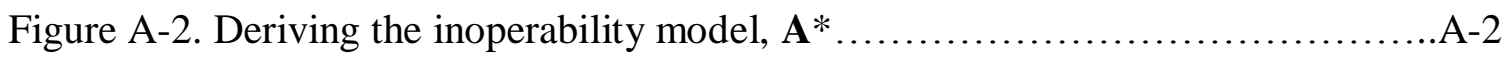

Figure A-3. Demonstrating interdependence of sectors..........................A-2

Figure A-4. Freight Analysis Framework - Virginia regions, network and example nodes

Figure A-5. Relative Economic Importance of Virginia Freight Highways.............A-8

Figure A-6. Estimate of Excess Trucking Costs per day based on AADTT, Detour

Length \& Relative Capacity of Detour. 


\section{LIST OF TABLES}

Table 1. Traditional Performance Measures recommended for Prioritizing Infrastructure

Improvement for Freight Transportation Needs

Table 2. Demonstration of freight module with sample values of expected improvement

Table 3. National Impact to BEA industries with a 100\% disruption to the trucking sector

Table 4. Virginia's Top Critical Commodities Handled by Truck .30

Table 5. Selected Freight Analysis Framework Commodities and BEA Industries for the Concept Demonstrations, and relative economic impact values from the inoperability input-output model

Table 6. Example products of Freight Analysis Framework Commodities

Table 7. Daily Truck Vehicle-Miles Traveled by Federal Vehicle Class on Virginia

Primary and Interstate Roadways

Table 8. 2005-2007 Truck Crashes on Virginia Primary and Interstate Roadways ..........34

Table 9. 2005-2007 Truck Crash Rates on Virginia Primary and Interstate Roadways ..34

Table 10. Kilotons of Commodities by grouped Freight Analysis Framework region ....38

Table 11. Route assignment estimations by grouped Freight Analysis Framework region

Table 12. Total Commodity Tonnage by Route for U.S. 460 Concept Demonstration ...39

Table 13. 2005-2010 Truck Crashes by Crash Type on U.S. 460 Study Corridor ….......40

Table 14. Measures required for Safety Calculations for U.S. 460 Study Corridor ….....40

Table 15. 2005-2010 Truck Crash Rates by Crash Type on U.S. 460 Study Corridor ....41

Table 16. Comparison of Average Crash Rates for U.S. 460 Study Corridor to All Virginia Primary and Interstate Roadways .........................................................42

Table 17. Economic hindrance by industry based on calculated excess trucking costs to

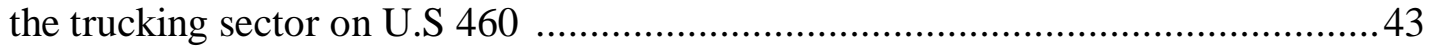

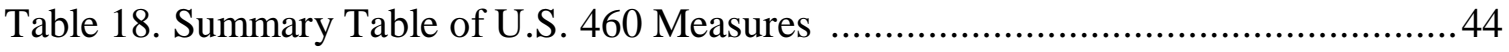

Table 19. Total Commodity Tonnage by Route for U.S. 29 Concept Demonstration .....48 
Table 20. 2005-2010 Truck Crashes by Crash Type on U.S. 29 Study Corridor .49

Table 21. Measures used for Safety Calculations for U.S. 29 Study Corridor .................50

Table 22. 2005-2010 Truck Crash Rates by Crash Type on U.S. 29 Study Corridor ......50

Table 23. Comparison of Average Crash Rates for U.S. 29 Study Corridor to All Virginia Primary and Interstate Roadways .51

Table 24. Economic hindrance by industry based on calculated mobility-based excess trucking costs to the trucking sector on U.S. 29 .53

Table 25. Summary Table of U.S. 29 Measures .54

Table 26. Comparison of Key Metrics for U.S. 460 and U.S. 29 Study Corridors ...........55

Table 27. Three decision model approaches to prioritize improvements ........................55

Table 28. Existing truck-based road user fee deployments and characteristics ...............58

Table A-1. Example Leontif (A) coefficient matrix, $\hat{\mathbf{c}}$ vector, and calculated

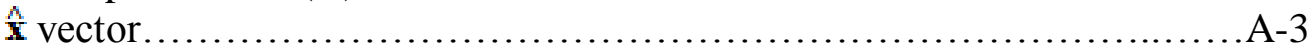

Table A-2. Normal and Reduced Industrial Output by a $20 \%$ reduction to the $6^{\text {th }}$ industrial sector using Inoperability Input-Output Model..................A-3

Table A-3. Matched sectors and economic rank given by inoperability Input-Output Model Example....................................................

Table A-4. Freight truck flows in kilotons for industrial sectors 1-5, 7-12 ........... A-6

Table A-5. Aggregated FAF O-D Table after scaling...............................6

Table A-6. Disaggregated O-D Table by Selected Nodes............................ A-7

Table A-7. Economic Value of Links between Selected Nodes......................A-7

Table A-8. Example of Link for Route Assignment................................A-7

Table B-1. BEA Make Table: The Make of Commodities by Industries, Annual InputOutput Accounts, 2007 ...........................................

Table B-2. BEA Use Table: The Use of Commodities by Industries, Annual Input-Output

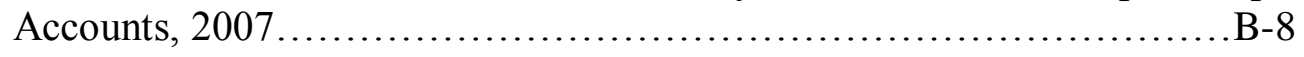

Table B-3. Normalized Make Table.............................................

Table B-4. Normalized Use Table............................................. 14

Table B-5. Input-Output Model: Leontif industry-by-industry technical coefficient

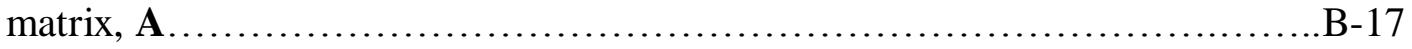


Table B-6. Input-Output Model vectors Ax, $\mathbf{x}$, and c........................... 20

Table B-7. Inoperability Input-Output Model A* matrix.......................

Table B-8. Inoperability Input-Output Model Results: Perturbation Vector, c*; Percent Disruption Vector, $\mathbf{q}$; and associated costs associated with the given disruption,

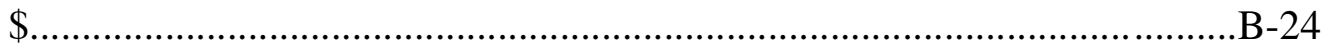

Table B-9. Standard Classification of Transported Goods (SCTG) Commodities matched to Bureau of Economic Analysis (BEA) Industries.....................

Table B-10. Economic Hindrance by BEA Industry due to Calculated Mobility-based Excess User Costs to the Trucking Sector............................ 27 


\section{LIST OF ABBREVIATIONS}

$\begin{array}{ll}\text { AADT } & \text { Average annual daily traffic } \\ \text { AADTT } & \text { Average annual daily truck traffic } \\ \text { ADMS } & \text { Archived Data Management System } \\ \text { ANPR } & \text { Automatic number plate recognition } \\ \text { BEA } & \text { Bureau of Economic Analysis } \\ \text { CD } & \text { Compact Disc } \\ \text { DSRC } & \text { Dedicated short-range communications } \\ \text { DOT } & \text { Department of Transportation } \\ \text { FAF } & \text { Freight Analysis Framework } \\ \text { FARS } & \text { Fatality Analysis Reporting System } \\ \text { FHWA } & \text { Federal Highway Administration } \\ \text { GNSS } & \text { Global Navigation Satellite System } \\ \text { GPS } & \text { Global positioning systems } \\ \text { GSM } & \text { Global System for Mobile Communications } \\ \text { GHG } & \text { Greenhouse gases } \\ \text { GDP } & \text { Gross domestic product } \\ \text { HGV } & \text { Heavy goods vehicles } \\ \text { HDM-4 } & \text { Highway Development and Management Tool } \\ \text { HERS } & \text { Highway Economic Requirements System } \\ \text { HERS-ST } & \text { Highway Economic Requirements System for States } \\ \text { HPMS } & \text { Highway Performance Monitoring System } \\ \text { HSIP } & \text { Highway Safety Improvement Plans } \\ \text { HSIS } & \text { Highway Safety Information System } \\ \text { IRI } & \text { International Roughness Index } \\ \text { IHS } & \text { Interstate Highway System } \\ \text { MPO } & \text { Metropolitan planning organization } \\ \text { NBI } & \text { National Bridge Inventory () } \\ \text { NBIAS } & \text { National Bridge Investment Analysis System } \\ \text { NCHRP } & \text { National Cooperative Highway Research Program } \\ \text { NCFRP } & \text { National Cooperative Freight Research Program } \\ \text { NHS } & \text { National Highway System } \\ \text { PSR } & \text { Present serviceability rating } \\ \text { PPP } & \text { Public-private partnership } \\ \text { RIMS-II } & \text { Regional Input-Output Modeling System } \\ \text { RSA } & \text { Road safety assessments or road safety audits } \\ \text { SHRP 2 } & \text { Second Strategic Highway Research Program } \\ \text { TIFA } & \text { Trucks Involved in Fatal Accidents } \\ \text { VMT } & \text { Vehicle-miles traveled } \\ \text { VDOT } & \text { Virginia Department of Transportation } \\ \text { V/C } & \text { Volume to capacity ratio } \\ & \end{array}$




\begin{abstract}
Fully operational highways are necessary for efficient freight movements by the trucking industry. Yet, the combination of limited funding and aging infrastructure creates a grim scenario for states, which are dependent upon the economic benefits of goods movements. This research develops a comprehensive, freight-based prioritization framework to identify freight infrastructure needs critical to maintaining economic vitality by incorporating economic metrics associated with infrastructure performance and level of service. Framework outputs are a prioritized list of infrastructure needs to sustain economically critical highway infrastructure with consideration to regional economic impacts and safety and mobility improvements. In summary, the framework first evaluates infrastructure needs on a specified highway network, then prioritizes those needs using a decision model to balance developed economic metrics that estimate regional corridor-wide benefits of the local improvement with severity of needs as quantified with conditional performance measures. The developed metrics and prioritization methods are consistently applicable to any region within the United States, and two concept demonstrations examine data from the Virginia highway system to demonstrate the methodology.

A review of literature documents existing and proposed highway improvement prioritization frameworks to incorporate best practices into the methodology developed for this research. While the literature discounts use of economic development performance measures and the economic importance of a corridor is typically taken for granted, this research adds the dimension of economic significance of a corridor into the prioritization process for infrastructure improvements to generate motivation for private sector investment. An input-output model is used to identify the most transportation dependent industrial sectors, which are then linked with commodity flows using the Federal Highway Administration's Freight Analysis Framework. A set of readily available conditional performance measures are selected to identify critical locations meriting improvements. The prioritization methodology is demonstrated by applying the three developed economic metrics to two concept demonstrations in Virginia: the U.S. 460 expressway between Petersburg and Hampton Roads and the U.S. 29 bypass in Charlottesville.
\end{abstract}




\section{CHAPTER 1: INTRODUCTION}

Highways are essential for efficient freight movements and economic activity. In 2007, trucks hauled $40 \%$ of freight ton-miles in the United States, while their market share continued to grow (BTS, 2011). Further, freight ton-miles carried on highways increased $31 \%$ between 1997 and 2007, bolstering the reliance of commerce on and necessity for efficient, uncongested highways (BTS, 2011). Yet, the state of transportation infrastructure in the United States has reached a critical point such that closures and congestion cause an immeasurable adverse effect on already suffering regional and national economies.

Bridge and pavement degradation occurs even faster than expected since freight tonnage on the highways has become much higher than was originally planned and continues to increase (ASCE, 2009). When the interstate system was constructed, beginning in the late 1950s, bridges were typically designed for a fifty-year lifespan; today, the average age of a bridge is 43 years old (AASHTO, 2008). According to the American Society of Civil Engineers (2009), 26\% of bridges in the United States are classified as either structurally deficient or functionally obsolete. With so many bridges in need of replacement, the cost of a new bridge so high, and inherent limitations with bridge inspections, unexpected closures or bridge failures are inevitable, such as that on I-35W in Minneapolis in 2007.

Such a road closure would be more economically detrimental to certain highways, depending on variables such as the number of trucks impacted, the commodities transported on that highway, additional delays, and adverse effects on alternate routes. While research has been conducted on infrastructure asset management (Cambridge Systematics et al., 2009; Dicdican et al., 2004; Shufon et al., 2003), often an inherent importance of a highway is assumed by its classification, e.g., interstate, national highway, etc., with minimal guidance to identify the most significant corridors. Although, there are no universal metrics to accurately describe the economic significance of a corridor or the magnitude and range of economic impacts by transportation investments (Peters et al., 2008; Meyer, 2001), performance-based planning should include wider measures than just operations, such as economic metrics (Meyer, 2001).

Moreover, despite the dominance of trucking in commerce and the economy, planning for freight is still an emerging area, even though truck-related issues represent a major part of what transportation planning attempts to address (Rodrigue et al., 2009; Chase et al., 2013). In general, the Second Strategic Highway Research Program (SHRP 2) notes the lack of tools for regional and local freight planning and the need for these tools to incorporate economic trends and freight activity, emphasizing that decisions related to freight can carry major implications for economic costs and regional competitive advantages (more so than those related to passenger transportation) (Chase, et al., 2013). Some tools and guidelines are available to assist freight analysis, including the Freight Analysis Framework (FHWA, 2010-a) to estimate and project freight flows between states and regions. Further, several state departments of transportation (DOTs) have performed studies on freight and infrastructure including the Virginia DOT's (VDOT) "Virginia Statewide Multimodal Freight Study" (Cambridge Systematics, 2009b; Cambridge Systematics, 2010) and Ohio DOT's, "Freight Impacts on Ohio's Roadway System" (2002). However, the minority of states that actually utilize freight performance 
measures use only a handful of disparate metrics, most of which are not even used to calibrate performance of specific state programs (Gordon Proctor \& Associates, 2011). Further, SHRP 2 underscores the need for methods that go beyond traditional financial measures to include other direct and indirect impacts, benefits, and costs (Chase et al., 2013).

Simply having a freight-based infrastructure prioritization framework in place may help DOTs secure funding for projects from public and private sectors. It has been shown that having an asset management plan in place can help secure funds from legislatures (Cambridge Systematics \& Meyer, 2007).

In spite of the current trend for tolling roadways to make up for funding shortfalls from the fuel tax, the trucking industry has indicated a passionate opposition to toll roads, with over half of truckers surveyed in one study citing a willingness to travel far distances out of the way to avoid tolls (Wood, 2011). However, this study also indicated trucking sector acceptance of tolling for new capacity, and a large need for better communicating the benefits of a facility for increased acceptance (Wood, 2011). With a freight-based infrastructure prioritization methodology in place to guide DOT investments to needs critical to goods movements, the trucking industry also may be more inclined to contribute funds through innovative payment strategies.

\subsection{Research Needs}

The combination of limited funding and aging infrastructure creates a grim scenario for states, which are even more dependent upon the economic benefits of freight movements in the current suffering economy. Economic metrics of highway infrastructure needs are required for a comprehensive, freight-based prioritization methodology to ultimately be integrated into strategic statewide and metropolitan planning organization (MPO) planning to identify and guide funds to infrastructure and operations improvements on critical corridors with regard to regional economic impacts, and structural, safety and mobility improvements. Freight needs merit consideration due to the significant role trucking plays in the economy. Prioritizing freight needs in this way may generate financial support from the private sector to promote their interests, while at the same time focused funds to specific freight corridors may draw truck traffic, easing truck-induced degradation on parallel highways.

\subsection{Purpose and Scope}

The purpose of this research is to develop economic metrics to assist with prioritization of infrastructure needs on critical freight corridors to maintain economic vitality. This research can inform a variety of stakeholders and decision-makers to make sustainable, informed decisions to support freight and economic activity, and is intended to be used as a tool to help leverage funding from the private sector based on derived benefits for projects not yet able to be subsidized by the public sector. This research builds on existing asset management strategies, identifying and prioritizing specific infrastructure needs on highways based on freight-based factors, such as the structural rating, economic 
importance, safety, and mobility. Developed economic metrics identify corridors critical to freight transport, quantifying potential corridor-wide benefits to be gained by investing in specific infrastructure needs. The developed metrics and prioritization methods are consistently applicable to any region within the United States, and concept demonstrations examine data from the Virginia freight network to demonstrate the developed methods. 


\section{CHAPTER 2: RESEARCH PLAN}

The following tasks fulfill the study objectives:

1. Conduct review of literature. Literature is examined on infrastructure needs identification and prioritization techniques and guidelines. A review of literature found numerous studies for asset management, but less work that helps to quantify the economic importance, based on freight movements, of aging bridges and pavements to the freight network for repair or replacement prioritization. The state of practice for prioritizing infrastructure needs in the United States and internationally is documented. Sources for the literature review include, but are not limited to the Virginia Center for Transportation Innovation and Research Library, Transport Research International Documentation, Worldcat, TLcat, and University of Virginia Engineering Library databases.

2. Investigate freight-specific performance measures to identify infrastructure needs. Based on the literature review and current DOT state of practice, a set of performance measures reflecting freight-based needs such as the structural soundness of bridges and pavements are identified, as well as measures to consider truck safety and mobility. Typical measures considered include truck speed, bridge load rating and deficiency rating, international roughness index (IRI) and present serviceability rating (PSR) pavement scores, and truck crashes.

3. Investigate strategies to measure economic importance. Economic importance of the freight network is established using Bureau of Economic Analysis (BEA) inputoutput multipliers that identify industrial sectors that are most dependent upon the transportation network. The flows of these sectors are linked to commodities in the Federal Highway Administration's (FHWA) Freight Analysis Framework, providing tonnage of these flows between and within selected regions. An origin-destination model is incorporated to disaggregate these interregional flows to the existing network, given by the Freight Analysis Framework. This prioritizes infrastructure needs by weighting the importance of corridors, specifically identifying those most critical to freight movements based on the commodities hauled on those corridors. Other economic metrics, specifically excess trucking costs derived from mobility and safety data are developed. Given the industries impacted based on the commodities on specific links, another economic metric is generated by inputting these excess trucking costs to the input-output model. These metrics are designed for private sector interests, quantifying potential benefits resulting from specific infrastructure investments.

4. Link economic importance and freight infrastructure needs. The use of VDOT's Asset Management System and Statewide Planning System are investigated to assist with infrastructure needs identification based on freight-based structural soundness, safety, and mobility performance measures selected in step 2 . Economic metrics developed in step 3 can be applied to prioritize the needs. A decision model is developed to balance economic priorities with the relative severity of safety, mobility, 
and structural needs, which can be translated into excess trucking costs. The output is a list of infrastructure needs for a specified highway network listing current excess trucking costs, projected regional economic benefits, and the prioritized ranking. The relationship between the required inputs and generated outputs of data to execute the prioritization methodology model are illustrated in Figure 1. Individual steps necessary to run the proposed prioritization methodology model are illustrated in Figure 2, where ovular substeps represent the need for data collection.

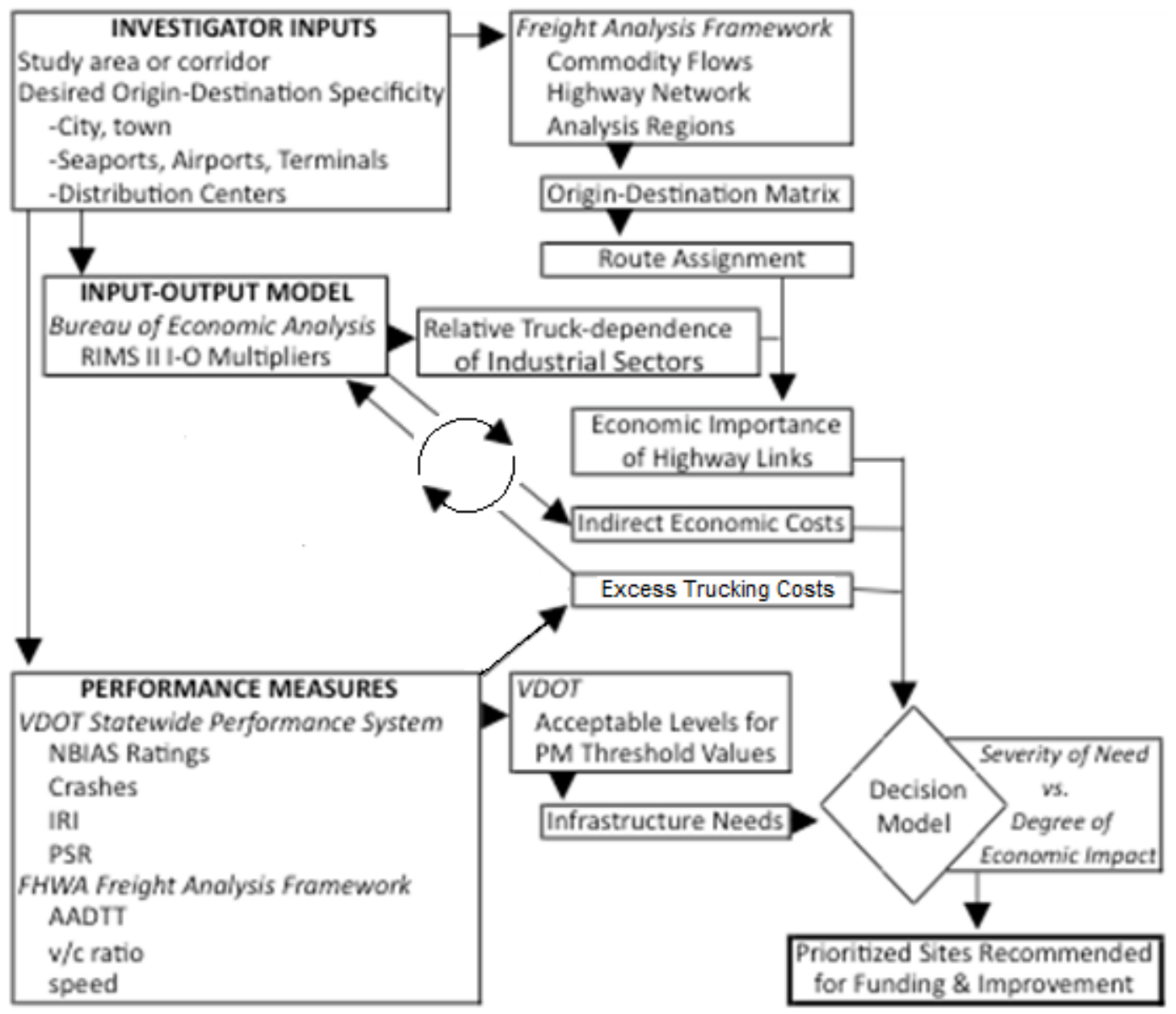

Figure 1. Flow of Inputs and Outputs of Proposed Methodology 


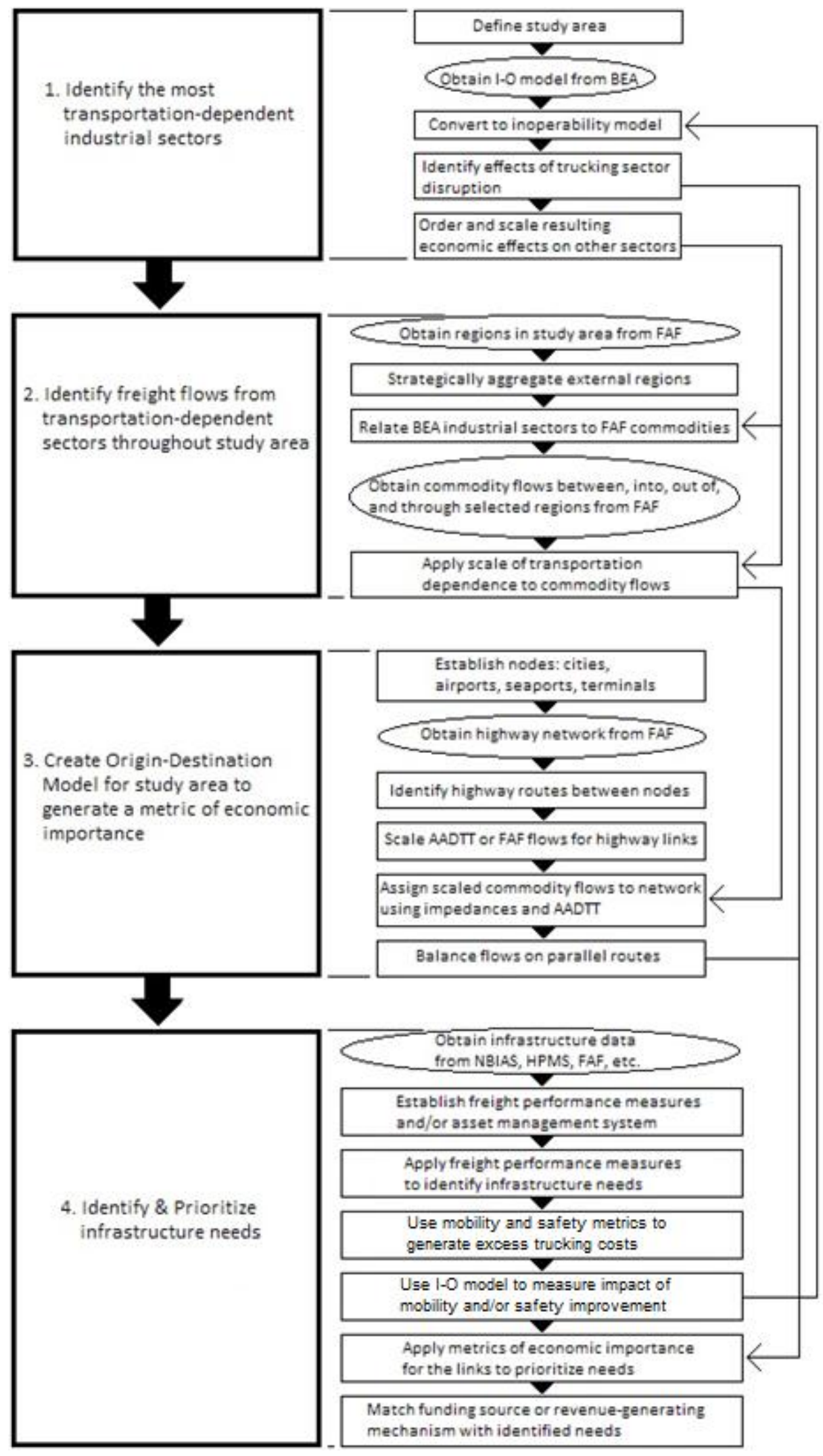

Figure 2. Proposed setup for Freight Infrastructure Prioritization Methodology 
5. Conduct concept demonstrations. To demonstrate the model developed in step 4, data from the Virginia freight network is used, although measured economic benefits extend to out-of-state freight stakeholders as well. Prioritization of infrastructure needs for selected corridors is made, that include economic costs associated with safety and mobility issues. Selected corridors will be U.S. 460 and U.S. 29 for which corridor studies have been conducted that can be used in this research for validation purposes. Specifically, proposed projects on these corridors: a limited-access highway for U.S. 460 and a Charlottesville bypass for U.S. 29 north, are evaluated for their economic benefits along the corridors. Both of these projects provide benefits to other routes from which traffic may be diverted by creating a cost savings for trucks, providing indirect economic benefits locally. Further, this research examines whether the proposed projects on these corridors have the potential to enhance economic development opportunities along the corridors due to improved access to markets; the corridor study areas extend beyond immediate the local improvement areas to include benefits to out-of-state markets.

6. Draw conclusions and recommendations. Based on concept demonstration results and analysis, conclusions and recommendations are provided for successful implementation of this research.

7. Prepare final report. This final report attempts to clearly outline the developed prioritization methodology and document the findings of the study. This document can assist stakeholders to make sustainable, informed decisions to support freight and economic activity, and help leverage funding from the private sector based on derived benefits for projects not yet able to be subsidized by the public sector. This tool is intended to help with difficult decisions during times of shrinking budgets and increasing costs to insure the preservation of infrastructure vital to freight flows and economic prosperity. 


\section{CHAPTER 3: TASK 1 - LITERATURE REVIEW}

\subsection{Infrastructure Improvement Prioritization State of Practice}

Asset management has become a major component of transportation agencies in recent years as increasing need for improvements is met with budget limitations (FHWA, 2008a). The FHWA (2008-a) defines asset management as: "a business process and a decision-making framework that covers an extended time horizon, draws from economics as well as engineering, and considers a broad range of assets [...that...] incorporates the economic assessment of trade-offs among alternative investment options and uses this information to help make cost-effective investment decisions."

Consequently, numerous studies have been performed to guide agencies and document best practices; the FHWA Asset Management website (FHWA, 2008-a) and the American Association of State Highway and Transportation Officials (AASHTO) Transportation Asset Management Today knowledge site (AASHTO, 2010) both serve as forums for contemporary asset management guidance, state of practice, and research, while Varma (2008) lists a comprehensive list of data sources for freight performance measures. Subsequent sections investigate data that is collected annually and available for input to existing and proposed infrastructure improvement frameworks.

\subsubsection{Collected data}

National databases currently contain information from every state on the condition of bridges and highways. The National Bridge Inventory (NBI) is federally mandated to monitor sub-structure, super-structure, deck, channel and channel protection, and culvert conditions for every structure over 20 feet (Cambridge Systematics et al., 2009; FHWA, 1995). For highway conditions, the Highway Performance Monitoring System (HPMS) includes data on highway condition, performance, use, and operating characteristics (FHWA, 2009-b). While certain information is maintained for all public roads, more data is collected for higher functional class roadways (FHWA, 2009-b). Additionally, over 40 states use the Pontis Bridge Management System, which includes NBI plus more detailed data (FHWA, 2008-a).

Other relevant databases exist but do not contain uniformly collected records for the entire country. Pavement management systems, for example, vary by state as there is no standard format (Cambridge Systematics et al., 2009).

Regarding safety data, a number of systems report a variety of information in ways that usually vary by state. There are no standards or consistency between states for reporting data on safety features like lighting, pavement markings or signage (Markow, 2007). One exception is the Fatality Analysis Reporting System (FARS), which documents all fatal crashes nationally, including truck-related crashes (NHTSA, 2010). The University of Michigan Transportation Research Institute (2010) maintains the Trucks Involved in Fatal Accidents (TIFA) database with extensive records dating to 1980 on fatal truck-related crashes nationally. State crash data systems, however, vary by state and are based on police accident reports. The National Accident Sampling System or General Estimates System contains an annual sample of crashes from these State Crash Data Systems, and extrapolates from this sample to estimate total crashes and their severity (Cambridge Systematics et al., 2009). The Highway Safety Information System 
(HSIS) is used by nine states and has crash records, roadway inventory, and traffic volume data (FHWA, 2010-c). It is used to study current safety issues, direct research efforts and evaluate the effectiveness of countermeasures (Cambridge Systematics et al., 2009). Finally, State Highway Safety Improvement Plans (HSIP) are reported annually to the federal government for the funding of safety-related enforcement and public awareness programs (Cambridge Systematics et al., 2009). These documents assist in identifying trends and safety improvement needs.

Mobility data can be obtained from several sources. The FHWA Freight Analysis Framework includes average annual daily traffic (AADT) and average annual daily truck traffic (AADTT), estimated capacity, volume-capacity ratio, speed, and delay information for a large freight highway network for 2007 and 2040 projections (FHWA, 2010-a). In addition, HPMS, Highway Economic Requirements System for States (HERS-ST), American Transportation Research Institute's FPMweb, and DOTs collect mobility measures (Cambridge Systematics et al., 2009; American Transportation Research Institute, 2010).

Environmental concern is a newer area of focus for state DOTs, thus little data is consistently collected and available for monitoring performance (Cambridge Systematics et al., 2009). The level of greenhouse gas (GHG) emissions can be estimated based on average fuel economies from vehicles at given speeds from available data. Additionally, since energy usage is a function of congestion, eliminating bottlenecks would improve mobility, while also reducing fuel consumption and emissions.

Detailed economic data from the private sector is difficult to gather, as it is not readily shared. However, some data sources, such as the United States Census Bureau and Bureau of Commerce have quality economic data on employment and businesses, as well as freight statistics like operation costs, revenue and employment (Cambridge Systematics et al., 2007). The Freight Analysis Framework estimates trucking commodity movements and the volume of long-distance trucks for specific highways (2010-a). Also, the Virginia Freight Study highlights "freight-intensive" industry reliance on transportation services and employment in those sectors (Cambridge Systematics, 2009-b).

A variety of freight data can be obtained for the aforementioned categories in general databases including HPMS, Freight Analysis Framework and FARS, including truck crash data, truck volumes, and truck fuel economy. The Freight Analysis Framework also contains commodity flow information by tonnage and value between 131 traffic analysis zones nationwide (FHWA, 2010-a). Numerous freight studies contribute additional information, also. The estimated costs of freight delays and bottlenecks caused by freeway or signalized intersections or steep grades are presented in a FHWA study (2008-b) and the TTI Urban Mobility Report (Schrank et al., 2010), while a study by ATRI (2010) identified the 100 most congested freight bottlenecks. A study by Hajek and Billing (2002) tracks trends in freight volume, size, weight and truck technology that affect pavement design; generally, policy \& law changes have allowed increasing weights and sizes over time, as truck volumes increase. Finally, stateconducted studies, such as the "Virginia Statewide Multimodal Freight Study" (Cambridge Systematics, Inc., 2009-b), document additional information like locations of distribution centers and their square footage, state bottlenecks, key intermodal connectors, truck parking availability at rest areas, truck accident numbers and locations, 
and current and projected level of service on the highway network. In general, freight data from the private sector are available, but difficult to compile due to costs and confidentially issues arising from the numerous disparate sources that collect and maintain the information (Varma, 2008).

\subsubsection{Existing Prioritization Frameworks}

The FHWA utilizes the National Bridge Investment Analysis System (NBIAS) to prioritize bridge investments. The NBIAS views all input bridges as equally important, and uses only NBI data to model maintenance, repair, rehabilitation, and functional improvement investment needs, with a modeling approach derived from the Pontis Bridge Management System (Cambridge Systematics et al., 2005; Robert \& Gurenich, 2008); specific rules may be applied to measures to set minimum acceptable conditions that would trigger the system to recommend replacement of the bridge (Robert \& Gurenich, 2008). The NBIAS then simulates a budget allocation for bridge projects over time to maximize user benefits while minimizing agency costs (Robert \& Gurenich, 2008).

The FHWA's Highway Economic Requirements System (HERS) optimizes highway investments based on HPMS travel forecasts, vehicle speeds, crashes, improvement costs, and predicted pavement and capacity deficiencies (Cambridge Systematics et al., 2005; FHWA, 2008-a; USGAO, 2001); a state version of this tool, HERS-ST is also available. Alternate improvements to highway segments are economically compared with a benefit-cost analysis for potential benefits derived from travel time reductions, crash reductions, vehicle operating costs, and agency maintenance, while costs include capital expenditures necessary to construct the improvement (Cambridge Systematics et al., 2005; FHWA, 2008-a; USGAO, 2001). In analysis, candidate projects are identified to correct pavement, width, and/or alignment deficiencies of a highway segment; performance criteria and/or specified funding constraints prioritize the selected candidate projects (Cambridge Systematics et al., 2005).

Further, many state DOTs use their own prioritization frameworks for infrastructure investments. Many of these have been documented through various studies to highlight innovative or best practices (Cambridge Systematics \& Meyer, 2007; Guerre et al., 2005; Li et al., 2005; Lownes \& Zofka, 2008; Pagano et al., 2005; Richardson et al., 2009; Shufon \& Adams, 2003; Stephanos et al., 2002).

Research has documented ways to streamline prioritization for diverse assets. A strategy used by Maryland for pavement project selection first groups similar projects by traffic volume, road type and class, condition, etc. before optimizing to select projects (Stephanos et al., 2002). Conversely, Ontario has found more consistency by combining numerous regional asset management outputs for bridges and pavements, scaling the cost-benefit outputs, and generating various what-if scenarios for an array of funding thresholds (Guerre et al., 2005). The New York State DOT uses trade-off analysis for pavements, bridges, safety, and mobility, based on project benefits versus excess user costs, which include costs of delaying travelers and freight, accident costs, and vehicleoperating costs (Shufon \& Adams, 2003).

Internationally, the Highway Development and Management Tool (HDM-4) has been successfully used in more than 100 countries to prioritize highway pavement 
investments (Cambridge Systematics et al., 2005). Requiring extensive calibration, it has seen limited application in the United States (Cambridge Systematics et al., 2005); HDM-4 was successfully calibrated for Washington State DOT use, however, to supplement the existing Washington State Pavement Management System for long-term pavement performance and investment needs (Li et al., 2005).

\subsubsection{Proposed Frameworks and Tools}

In addition to a wide array of frameworks that currently serve the purposes of many DOTs, other approaches and general guidelines for handling agency assets have also been proposed.

Fundamentally, the International Infrastructure Management Manual (2006) provides guidance for developing a general asset management framework. It utilizes an optimized decision making algorithm for individual projects, and includes benefit-cost analysis and multi-criteria analysis.

Recognizing the need for better asset management guidance, NCHRP Report 545 (Cambridge Systematics et al., 2005) developed analytical tools for decision-making. The tools are designed to show short-term consequences of implementing various projects within one to three years, and 10-20 year simulations resulting from various magnitudes of investments into each of the asset management classes.

The National Cooperative Highway Research Program (NCHRP) Report 632 recognizes the importance of the Interstate Highway System (IHS) specifically, as vital to the competitiveness of the United States economy (Cambridge Systematics et al., 2009). The report develops a framework for managing interstate assets, including those other than pavements and bridges. Further, performance measures are provided, alongside details on collecting, managing and using data, as well as tools to support the program and risk management guidelines. Guidance to successfully implement the framework is also detailed.

\subsection{Designated Highway Networks}

The framework developed in this research could be applied over a wide range of highway systems, incorporating local and state roadways to capture the ends of freight trips, or only the major highways that are included in the Interstate and National Highway System.

The IHS includes 46,726 miles of limited access highways nationally as of 2002 (FHWA, 2009-a), and carries the highest freight volumes per mile.

The National Highway System (NHS) incorporates a 160,000-mile network of roadways, including the IHS, that are important to the nation's economy, defense and mobility (FHWA, 2010-b). The NHS contains only $4 \%$ of the nation's roads, but carries approximately $75 \%$ of heavy truck traffic (Slater, 1996). Further, it complements other freight transportation modes by offering efficient intermodal connections to 198 ports, 207 airports, 190 rail/truck terminals, and 58 pipeline terminals (Slater, 1996).

Additionally, the National Network is a companion to the NHS, a distinct 200,000-mile network of freight highways that include all of the IHS and 65,000 miles not on the NHS, while the NHS includes 50,000 miles not in the National Network 
(FHWA, 2010-a). The National Network supports interstate commerce through regulation on the size of trucks (FHWA, 2010-a).

To focus investment efforts for freight infrastructure, both the American Road and Transportation Builders Association (ARTBA, 2010) and AASHTO (2007) are lobbying for the establishment of Critical Commerce Corridors. These corridors would likely include most or all of the IHS, portions of the NHS, new multimodal trade corridors and new designated truck-only lanes (ARTBA, 2010).

The Freight Analysis Framework includes a network of over 447,400 miles of highways including rural arterials, urban principal arterials, all of the IHS, NHS, and National Network, and intermodal connectors (FHWA, 2010-a).

\subsection{Literature Review Discussion}

Existing asset management tools used by state DOTs, i.e., VDOT, are recommended for use in the framework model, which will ease analysis and barriers to future implementation. If access to these resources is restricted, the asset management recommendations put forth in NCHRP Report 632 are recommended as an alternative.

Numerous sources for data collected nationally have been identified, including the NBIAS, FARS, HPMS, and Freight Analysis Framework. Incorporating nationally collected data to the framework model will facilitate use across multiple agencies.

Because the Freight Analysis Framework provides reliable freight data and forecasts for the most important freight highways, this network is recommended for use of the framework model in broader applications. If necessary, additional links to commercial hubs of freight activity including major distribution centers could also be included. 


\section{CHAPTER 4: TASK 2 - INVESTIGATE PERFORMANCE MEASURES}

The FHWA (2010-a) defines performance measures as: "evidence to determine progress toward specific defined organizational objectives. This includes both quantitative evidence (such as the measurement of customer travel times) and qualitative evidence (such as the measurement of customer satisfaction and customer perceptions)." A multitude of performance measures are used or proposed domestically and internationally by DOTs and private firms to monitor a variety of assets and activities from truck fleet operations, costs and efficiency to infrastructure integrity and pavement quality, detailed in the following subsections (AASHTO, 2007-a; Cambridge Systematics, 2000, 2009-a; Cambridge Systematics et al., 2005, 2006-b, 2009; Czerniak et al., 1996; Forkenbrock \& Weisbrod, 2001; FHWA, 2004; Hagler Bailly Services, Inc., 2000; Harrison et al., 2006; Hedlund, 2008; Li \& Sinha, 2004; Lownes \& Zofka, 2008; Miller et al., 2002; Neumann, 1997; Poister, 1997; Reed et al., 1993; Shaw \& PBS\&J, 2003; Shufon \& Adams, 2003; TransTech Management, Inc., 2003; Varma, 2008).

The National Cooperative Freight Research Program (NCFRP) Report 3 aims to establish a "comprehensive, objective, and consistent set of measures of performance of the U.S. freight transportation system" (Proctor, 2010). That research found private freight sector and state DOTs to measure highly variable sets of performance measures, due in part to differing priorities in costs and network performance, respectively (Proctor, 2010).

Many state DOTs already record performance measures on their highways that include or affect freight transportation movements, such as pavement, structural, mobility, and safety measures. However, the minority of states that actually utilize freight performance measures use only a handful of disparate metrics, most of which are not even used to calibrate performance of specific state programs (Gordon Proctor \& Associates, 2011).

A Minnesota study highlighted a number of freight performance measures, most of which required further development for use, including travel times for intercity routes, to intermodal terminals and to global markets, shipping rate competitiveness, crash rates by mode, and bottleneck information (Larson \& Berndt, 1999); data was more readily available for measures of mobility, transportation investment, and economic cost-benefits for most freight projects. A report prepared for FHWA (Hagler Bailly Services, Inc., 2000) reviews potential performance measures and recommends seven indicators for measuring freight performance. However, not all of these indicators, such as customer satisfaction, can be readily accessed from available data sources.

A report by Shufon and Adams (2003) demonstrated a method prototyped by New York State DOT in which performance across all categories is converted to excess user costs; for example, pavement degradation leads to increased user costs from tire and parts consumption, while accidents, detours, and congestion create added user costs from wasted time and fuel.

A number of traditional performance measures are already widely collected and used in many existing asset management systems, which directly apply to the infrastructure needs of freight transportation. These performance measures quantify the structural integrity of bridges, pavement quality, safety, and mobility, and are described in the sections below and presented in Table 1. 
Table 1. Traditional Performance Measures recommended for Prioritizing Infrastructure Improvement for Freight Transportation Needs

\begin{tabular}{|l|l|l|}
\hline Focus & Performance Measure & Unit/Rating \\
\hline \multirow{2}{*}{ Structural } & Structural Evaluation & $0-9$ \\
Integrity of & Deck Geometry & $0-9$ \\
Bridges & Underclearances, Vertical \& Horizontal & $0-9$ \\
& Bridge Load Limits Posting & $0-5$ \\
\hline Pavement & International Roughness Index & inches/mile \\
Quality & Present Serviceability Rating & $0-5$ \\
\hline \multirow{3}{*}{ Safety } & Truck Crash Rate & truck crashes/mil-VMT \\
& Truck Fatality Crash Rate & truck crash fatalities/mil-VMT \\
\hline \multirow{3}{*}{ Mobility } & Adverse Safety Geometric Deficiencies & $0-9$ \\
& Volume/Capacity Ratio & unitless \\
\cline { 2 - 3 } & Truck VMT & mil-VMT \\
\cline { 2 - 3 } & Average Travel Speed & miles/hour \\
\hline
\end{tabular}

\subsection{Structural Integrity of Bridges}

A variety of measures are collected to assess the performance of bridges; many of these measures are maintained as part of the NBI. Geometric characteristics such as bridge deck width, vertical and horizontal clearances, and lane and shoulder widths are recorded and can indicate restrictions imposed upon freight traffic. Some agencies monitor network performance by tracking the average health index of bridges, the percentage of bridges with a sufficiency rating less than 50 or the percentage of bridges with deck, superstructure, or substructure NBI rating of four or less. Load ratings are also measured and are critical to freight transport. Finally, excess user costs for each bridge can be measured based on the probability of incidents and closures due to traffic volumes and lane geometry, the resulting detour length and added costs of fuel and time delay.

Recommended traditional performance measures for a freight prioritization framework are based on the NBIAS outputs, which use NBI data. Specific rules might be applied to NBIAS analysis to specify more stringent NBI Appraisal Ratings, Items 67-70, which measure the adequacy of the structure by the type of highway it is serving by structural evaluation based on loads and traffic volumes, deck geometry, vertical and horizontal clearances, and bridge restrictions (FHWA, 1995). These measures directly apply to freight flows based on limitations they may impose, or soon impose, on trucks.

\subsection{Pavement Quality}

Many measures are collected nationwide for the HPMS. The IRI is a standard measure of ride quality, while PSR attempts to assess the structural integrity of the pavement. Using IRI, excess user costs can be calculated based upon tire wear and parts consumption given rougher surfaces. Pavement geometrics of lane and shoulder width are also documented, as well as skid resistance and structural adequacy. A number of indices exist that utilize IRI and pavement distress data such as the Pavement Quality Index, 
Rideability Index, Distress Index, and a vehicle-miles traveled (VMT) weighted

pavement condition. States also monitor network performance using a number of metrics such as the percentage of miles in good, fair or poor condition, the percentage of miles below a threshold acceptable condition level, the average condition, percentage of miles with weight restrictions due to structural limitations, and the percentage of truck VMT or tonnage affected by weight restrictions.

For the purposes of a freight prioritization framework, traditional performance measures recommended to incorporate the structural adequacy of pavement should be the IRI and PSR. Selection of these measures is based on their nationwide availability and general acceptance for measuring pavement quality and structural integrity, particularly due to the importance to freight transportation.

\subsection{Safety}

Typical performance measures for highway safety are based on the crash rate or fatality rate. Data on vehicles involved in an incident are recorded such that the truck crash rate and truck fatality rate are also available, as well as causes attributable to construction zone, speed, and/or traffic violation crashes. Many factors can have negative safety affects, including geometrics like grade, alignment, horizontal and vertical clearances and shoulder, lane, and bridge deck widths, skid resistance, travel speed, railroad crossing adequacy, luminance, and sight distance. Safety performance can also be measured in terms of the costs associated with crashes, injuries and fatalities, or delay, and the costs to implement safety countermeasures. Further, network performance can be measured by the percentages of reduction in motor carrier crash rates, traffic exceeding the speed limit, VMT in various ranges of volume/capacity, commercial vehicles weighed, overweight commercial vehicles, commercial vehicles undergoing safety inspections, and commercial vehicles passing those safety inspections. Seat belt usage by drivers and passengers is also relevant, measured either by the number of law enforcement citations, unrestrained driver and passenger fatalities, or surveys. Finally, the Hazard Index, measured by crash/VMT by severity, and Accident Risk Index, or Safety Index also serve as metrics to a highway segment's relative safety.

For a freight-based framework, the most relevant safety performance metrics are truck crash rate, truck fatality crash rate, and geometric deficiencies that contribute to crashes.

\subsection{Mobility}

Mobility is often measured by travel time, delay, and speed. Related measures include standard deviation of travel time, volume/capacity ratio or level of service, density, customer ratings of trip time, reliability, congestion severity and travel cost, relative delay rate versus other routes, excess user costs due to person or freight shipment delay, intersection delay, detour length, delay due to incidents and/or congestion, percentage of highways or lane-miles congested during peak period, travel rate in minutes per mile, and variation in average speed. VMT is another common measure of mobility, including the 
amount or percent VMT in congestion, VMT/lane-mile per capita, and truck VMT by light duty, heavy duty, and through trips. Indices of mobility include the congestion severity index (hours of delay/million VMT), roadway congestion index (cars/road space), buffer time index (percentage of extra time needed to be on-time $95 \%$ of the time), mobility index (ton-miles * average speed), speed reduction index (ratio of speed declines across facilities), travel rate index (ratio of peak travel-time to off-peak travel time, the additional time to congestion), and misery index (a measure of the severity of congestion on the worst $20 \%$ of trips). Additional freight-related measures of mobility include the percentage of on-time shipments, the shipper's ability to reliably reach desired suppliers or markets within specified service parameters like time, cost, etc., average circuity for truck trips between selected origins and destinations, ton-miles travelled by congestion level, line-haul speed, capacity restrictions, and miles of freight routes with adequate capacity.

For the purposes of a freight highway infrastructure needs prioritization, recommended traditional freight-relevant mobility measures include: volume/capacity ratio and truck VMT, again because of the potential for more widespread collection and use of these measures, as presented in Table 1. 


\section{CHAPTER 5: TASK 3 - MEASURING HIGHWAY ECONOMIC IMPORTANCE}

\subsection{Economic Impact of Freight}

According to the United States DOT Bureau of Transportation Statistics, transportation services provide more than $5 \%$ to the production of the United States gross domestic product (GDP), with more than half of that attributable to for-hire or in-house trucking (FHWA, 2010-a). The Freight Analysis Framework estimates for 2002 indicate that trucks carried almost $60 \%$ of freight tonnage, of a total 53 million tons daily, and over two-thirds of the value of goods that totaled $\$ 36$ billion per day (FHWA, 2010-a).

There are several types of economic benefits that stem from highway infrastructure projects as described by the FHWA (1996). First, industry productivity can increase as a result of cost savings caused by infrastructure improvements, which in turn may stimulate the economy (FHWA, 1996; Nadiri and Mamuneas, 1996). Highway construction projects provide employment to workers, and thus benefit the local economy. Finally, by improving mobility and safety, direct benefits are provided to drivers.

Determining the comprehensive dollar value of economic benefits is difficult. Potts (2008) notes how little information exists regarding the dependence of each state's economic prosperity on transportation services provided by highways in other states. Thus, it is complicated to estimate the economic value of individual transportation projects given the established corridor's value, as a whole.

The United States Census Bureau's Commodity Flow Survey (2007), used in the Freight Analysis Framework, maintains information on the tonnage, ton-miles, and dollar value of goods shipped within and between states and metropolitan areas by truck. Studies by Nadiri and Mamuneas (1996, 1998) and NCHRP Project 20-24(23) (2007) have quantified the macroscopic influence between major industries, transportation, and national productivity growth.

It has been argued that most transportation investments have no significant impact on economic activity (Meyer, 2001; VTPI, 2009). Indeed, while transportation investment can increase accessibility or mobility in an area, taxes, labor laws, social amenities, or other regional conditions also affect economic growth (ECMT, 2002; Peters et al., 2008; Rodrigue et al., 2009). Yet, having an efficient and modern transportation network will favor many economic changes that are, for the most part, positive (Rodrigue et al., 2009). Even so, with an already weak causal link between transportation investment and economic growth, that link is inclined to level off after reaching a certain investment threshold, e.g., the mature United States highway systems (ECMT, 2002).

However, failure to maintain investment in transportation can cause a decline in private investment in an area, resulting in declining economic conditions (Eno Transportation Foundation, 1996; Peters et al., 2008; Rodrigue et al., 2009). But in general, transportation investments have the potential to provide broad benefits to regional economies over time if made at the right time for the right locations to nurture future growth, though no guarantee of economic development can ever be predicted (ECMT, 2002; Eno Transportation Foundation, 1996; Rodrigue et al., 2009).

Calculating the economic impact of an infrastructure investment is full of uncertainty and while numerous models have been developed for this purpose, all have 
faults, e.g., problems with double counting benefits (ECMT, 2002). Therefore, a transportation project must be merited on the basis of transportation benefits and not just economic projections, lest inferior transportation projects be built (ECMT, 2002). Besides, even primary transportation benefits like increased safety, emissions reductions and reduced travel time can promote economic growth (ECMT, 2002).

Measuring the precise indirect economic impacts of a project may be difficult, but even a qualified one-to-five ranking can be useful, since some projects are more inclined to promote economic development than others, as demonstrated by the Oregon DOT (McMullen, 2010).

A study by Rico, Mendoza, and Mayoral (1996) recognizes the merit of identifying the economic importance of highway and rail corridors due to their contribution to national prosperity. Data was gathered at weigh stations and through the use of surveys, and then extrapolated. Four differing categories of prioritization were generated for a corridor based on truck volume, tonnage, cargo value, and a benefit-cost ratio; emphasis is placed on the notion that highways carrying a higher economic value of freight are more important than others transporting higher tonnages of low-value freight.

Another strategy examines individually the freight flows of a region's most significant commodities, then layers them together to identify the most important corridors allowing for a less data-intensive, better understood model (Souleyrette et al., 1998). Corridor importance is noted as those carrying the most tonnage of the selected commodities, however the methodology for commodity selection is not detailed.

It is important to note that fuel prices, a major component of trucking costs, are linked to the costs of almost all consumer goods (Emerson, 2012). Businesses that operate on a small profit margin, such as groceries, are impacted by anything that affects costs, including shipping costs; businesses may absorb excess shipping costs to a certain point, but pass them along to consumers if costs rise significantly (Emerson, 2012).

\subsection{Performance Measures of Economic Impacts of Transportation}

Studies have shown that transportation investments impact economic activity directly and indirectly, but measuring that impact can be hard to assess due to the many factors that can influence the economy (Meyer, 2001; Peters et al., 2008). A review of performance measures for the impact of transportation investment on local and regional economies found a variety of measures developed to measure economic impact, but little consistency between agencies (AASHTO, 2007-a; Cambridge Systematics, 2000; Cambridge Systematics et al., 2005, 2006-b; Miller et al., 2002; Neumann, 1997; Peters et al., 2008; VTPI, 2009). These measures include freight mobility, relative unemployment, direct or indirect number of jobs created by transportation projects, job retention, whether a transportation project supports of in-state jobs, number of jobs, high-paying jobs, or licensed businesses within ' $x$ ' minutes of ' $y$,' economic indicators of goods movements, percent of manufactures or shippers who relocated for transportation purposes, regional truck VMT per unit of regional economic activity, shipping costs, value of goods shipped on a route, and tonnage originating or terminating in a region. Further, economic models include the use of GIS to list and classify businesses and a REMI model to show changes in business output, personal income, employment, and population as the result of 
infrastructure investments. Despite this diverse array of measures, there are no universally accepted metrics to accurately describe the magnitude and range of economic impacts of transportation investments (Meyer, 2001; Peters et al., 2008). Further, economic performance measures face substantial challenges in application due to the time lag associated with assessing the measure and the complexities involved with confirming the cause-effect relationship with transportation investment (Meyer, 2001).

While mobility and accessibility measures are a common indicator of economic impacts, it has been found that the reduction of delays, vehicle operating costs, and accident costs have a positive impact only in areas that are already economically strong (Meyer, 2001). Regarding mobility, maximum economic benefits are derived from increased system efficiency (VTPI, 2009)

Further, job creation is often measured as an economic impact of transportation investment. This is a contentious measure, however; job creation in one area has been suggested to come at the expense of jobs or job growth elsewhere in the region (Meyer, 2001), but others argue that economic benefits are not so balanced (Eno Transportation Foundation, 1999). Moreover, direct jobs are likely to be generated as the result of any infrastructure investment, while many factors influence unemployment figures besides transportation investments (Peters et al., 2008).

Shipping costs are included as a performance measure based on analysis revealing that projects that reduce industrial transportation costs, e.g., shipping costs, will also increase productivity (VTPI, 2009). At the same time, it is argued that highway investments are not the most fruitful way to increase productivity (VTPI, 2009).

Despite all these potential performance measures, however, the Second Strategic Highway Research Program (SHRP 2) underscores the need for methods that go beyond traditional financial measures to include other direct and indirect impacts, benefits, and costs (Chase et al., 2013).

\subsection{Input-Output Modeling}

Input-output data is another readily available source of economic data. The Bureau of Economic Analysis (BEA) maintains regional input-output multipliers called the Regional Input-Output Modeling System (RIMS II) for areas encompassing at least one county (BEA, 2010). Multiregional input-output models have been used for transportation and freight issues (Cascetta, 2001; Hoel et al., 1967; Mahady and Lahr, 2008; Voigtlaender, 2002).

The input-output model was developed by Leontief in the middle of the 20th century (Hoel et al., 1967). In its basic form, economic data from various industries within a region are displayed in a table to show the relationships between those industries (Hoel et al., 1967; Isard, 1960). Industrial sectors are listed both in row and column headings; the production and distribution characteristics of these sectors are presented with the input to a sector from other industries displayed along a column, while that sector's output to other industries is recorded along the row (Hoel et al., 1967; Isard, 1960). Total inputs will balance total outputs when households and capital losses or profits are also included into the table (Hoel et al., 1967; Isard, 1960). The table can be expanded to include other regions and show interregional as well as intraregional 
economic flows (Hoel et al., 1967; Isard, 1960).

Multipliers are created by calculating percentages of the totals for the column/row; these multipliers can then be used to create projections based on speculative inputs for select industries using an iterative process where row sums are used as inputs to unknown columns, then balanced again until inputs equal outputs.

The inoperability input-output model is derived from the Leontif input-output model and shows the economic interdependencies of different industrial sectors. Thus, it can show the economic impact to all sectors due to a disruption to one or more sectors. The inoperability input-output model was first presented by Haimes and Jiang (2001) and further refined and related to highway applications (Crowther, et al., 2004; Haggerty, et al. 2008; Haimes et al., 2005-a; Haimes et al., 2005-b).

Haimes and Jiang (2001) develop an application of the inoperability input-output model to infrastructure instead of commodities, for instance between power plants, the transportation sector, and hospitals. However, the methodology might be able to show, for example, the dependence of "Bridge A" upon "Bridge B" in the network. The authors emphasize, however, extensive data collection and data mining would be necessary to assemble the Leontif matrix, showing the relations and reliance between various pieces of infrastructure. While this application focuses on the interdependence of the infrastructure, it is my opinion that it would not adequately demonstrate the dependence of industrial sectors on the trucking sector, and thus highway infrastructure.

In the context of terrorism, the inoperability input-output model has been applied to Hampton Roads tunnels in Virginia (Haimes et al., 2004). This study examined the impact of a closure or reduced capacity in the tunnel. Although the inoperability inputoutput model is a demand-based model, it can be applied in this case because a reduction in supply necessitates reduced demand; in other words, consumption will adjust from "normal" levels in the event that supply is reduced (Haimes et al., 2004).

In a 2004 study, Crowther et al. directly link infrastructure performance to specific economic sectors from the inoperability input-output model. Specifically, the trucking sector is linked to highway infrastructure performance (i.e., roads and bridges).

In conjunction with the link between trucking costs, e.g., fuel costs, and costs of goods, Mahady and Lahr (2008) note in their use of the input-output model that transportation cost reductions are likely going to lower producer costs, however these benefits can also be interpreted as production increases. Thus, in their study they justify the conversion of travel time reductions to cost savings. This cost savings reduces industries' input to the trucking sector and translates to increased productivity in other sectors of the economy.

\subsection{Measuring Highway Economic Importance Discussion}

Perhaps because of the difficulty in determining the comprehensive dollar value of economic benefits, no universal metrics accurately describe the economic significance of a corridor or the magnitude and range of economic impacts by transportation investments. This research seeks to develop freight-highway economic performance measures to address this need. 
For this study, input-output multipliers are obtained from the BEA. An inoperability input-output model is developed to identify those industrial sectors most dependent upon the trucking sector, specifically highway infrastructure. Then using national commodity flow information available from the FAF regions, specific route assignments can be made to the selected freight highway network. Links used to transport more commodities of the more truck transportation-dependent industrial sectors are designated a higher rank of economic importance.

Excess trucking costs can be calculated for a highway link based on a number of factors. This study will utilize AADTT from FAF to estimate excess trucking costs for mobility based on potential travel time saving, and for safety based on a potential reduction in truck crashes. Additional measures of excess trucking costs might be derived using AADTT and detour length, and estimated congestion based on capacity of alternate route given a closure due to infrastructure (structural) failure.

Finally, the economic hindrance from inefficiency of excess trucking costs estimates a value of increased economic productivity that is otherwise spent on transportation costs, and can be calculated separately for each highway link. Based on the commodities on each highway link, the trucking sector input can be recalibrated in the input-output model based on the sectors that use the link to determine the economic impacts to other sectors given excess trucking costs for each highway link in the network for a given period (Mahady and Lahr, 2008).

The development of these three economic metrics is detailed in a demonstration methodology in Appendix A. In short, these three economic metrics are:

1. Relative economic importance of highway links based on sectors most dependent upon the trucking sector, according to a disruption to the trucking sector using the inoperability input-output model, and an origin-destination model with route assignments for specific commodities of those truck-dependent sectors.

2. Excess trucking costs of highway links based on the given AADTT and A) estimated reduction in delay based on potential travel time improvements (mobility) and B) potential reduction in truck crashes given an infrastructure improvement. Additional measures that might be considered include excess trucking costs based on the degree of congestion and delays expected from a closure due to infrastructure (structural) failure given AADTT and detour length of an alternate route. Trucking costs for mobility purposes are based on TTI's Urban Mobility Report value of commercial vehicle time at $\$ 105.67 /$ hour (Schrank et al., 2010).

3. Economic hindrance from inefficiency of excess trucking costs estimates a value of increased economic productivity that is otherwise spent on transportation costs, and can be calculated separately for each highway link. As an example, changes in fuel prices are linked with changes in the costs of goods (Emerson, 2012). Other excess trucking costs likewise require industries to pay costs on shipping that might otherwise be invested elsewhere and spurn economic development, such as expanding business, increasing employment, etc. Based on the commodities on the highway links (from metric 1), the trucking sector input can 
be recalibrated in the input-output model based on the sectors that use the link to determine the economic impacts to other sectors given excess trucking costs (from metric 2) for each highway link in the network for a given period (Mahady and Lahr, 2008).

One concern with the use of multiple economic metrics is that some of the benefits or costs that are measured with one metric might already be included in the benefit or cost of a separate metric; this would constitute double counting and should be avoided. For the economic metrics proposed here, double counting among these metrics could occur if all are considered simultaneously, particularly metrics 1 and 3. Thus, it is recommended these two measures be applied separately. 


\section{CHAPTER 6: TASK 4 - LINK ECONOMIC IMPORTANCE AND FREIGHT HIGHWAY INFRASTRUCTURE NEEDS}

Following the development of the economic performance measures in the previous section, the next step is to incorporate these measures into an asset management system. This will provide a method to prioritize freight highway infrastructure needs for selected corridors.

\subsection{State of Practice}

States already use asset management tools to prioritize infrastructure needs as identified in Section 3. However, these tools are primarily based on passenger movements (Chase, et al., 2013). In general, the Second Strategic Highway Research Program (SHRP 2) notes the lack of tools for regional and local freight planning and the need for these tools to incorporate economic trends and freight activity, emphasizing that decisions related to freight can carry major implications for economic costs and regional competitive advantages (more so than those related to passenger transportation) (Chase, et al., 2013).

Thus, this research builds upon existing tools for smoother integration with current practice, rather than building an entirely new comprehensive asset management tool. The decision model for this research is detailed below as a module within an existing state DOT asset management tool.

Currently, VDOT uses the Asset Management System to identify infrastructure needs for existing pavement and bridge assets. For safety needs, the Virginia Highway Safety Program, a part of the federal HSIP conducts road safety assessments (RSA, also known as road safety audits) and uses crash rates to prioritize locations with safety needs. Many freight relevant performance measures are already captured by these systems, including those related to structural soundness, pavement quality, and mobility, which are housed in the VDOT Archived Data Management System (ADMS).

Additional freight measures identified in Sections 4 and 5 might be integrated as a separate freight module. The distinction of truck-related crashes and fatalities from total crashes and fatalities, for instance, may lead to the identification of hotspots in need of specialized safety treatments for trucks. Alternatively, these freight metrics might be incorporated into the decision-making process for specific functional classifications in the network, such as interstates and principal arterials. The resulting output will be a list of infrastructure needs for specified freight corridors listing current excess trucking costs, projected regional economic benefits, and the prioritized ranking. A proposed schematic for incorporating additional freight-relevant measures from the Freight Analysis Framework, as well as those proposed in this research, are shown below in Figure 3, where dashed lines represent proposed links for inclusion of freight considerations to the existing asset management system. 


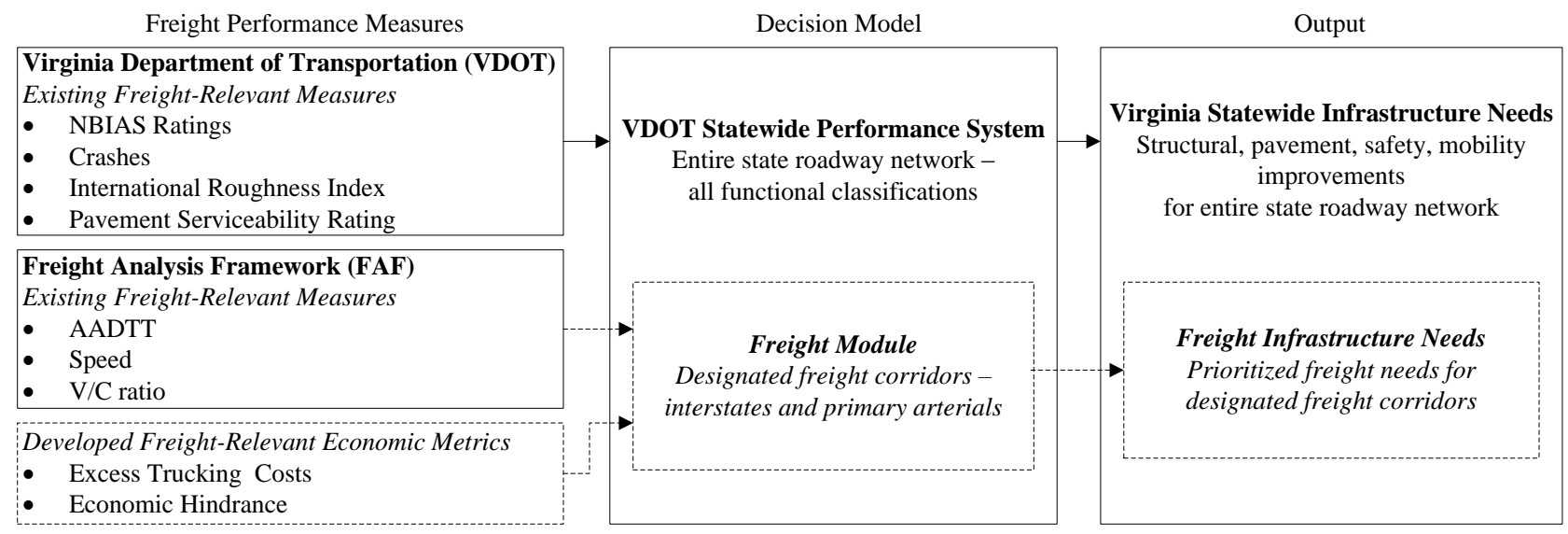

Figure 3. Example of integrating new metrics into an existing asset management system

\subsection{Developing a Decision Model to Prioritize Freight Highway Infrastructure Needs}

As mentioned for the Virginia Statewide Planning System, it is likely that a given asset management tool will already incorporate some freight-relevant performance measures. To avoid duplication, the inclusion of these performance measures in the freight highway infrastructure decision model is discouraged. Instead, the focus should be placed upon freight-relevant performance measures that are readily available for relevant freight corridors, such as those detailed in Section 4.

It cannot be expected that all freight-relevant performance measures will be consistently available for all regions, or even for specific corridors or areas within a region. Thus, where data is unavailable for all corridors or areas to be evaluated in the decision model, either default or qualified values may be employed as a placeholder or best guess for comparison.

The Virginia Statewide Planning System, as depicted in Figure 3 already collects a number of freight-relevant performance measures. These measures include NBIAS ratings for structures, IRI and PSR for pavement quality, and crashes for safety, among others.

For the purposes of this research, the freight module that will be developed and demonstrated includes additional freight measures gathered from the Freight Analysis Framework, VDOT crash database, and freight-relevant economic metrics developed herein. Measures to be recommended from the Freight Analysis Framework include volume to capacity (V/C) ratio, speed, and AADTT. As mentioned in Section 5.4 above, to eliminate double counting only select measures developed in this research, namely excess user costs for trucks and economic hindrance are recommended to be used.

Necessarily, the output from the freight module of the decision model will be a prioritized list of freight highway infrastructure needs. This research will examine several possibilities for the decision model, including an equal weighting approach, where prioritization will be determined based on the sum of equally scaled performance measures for each identified need, and weighted approach for both mobility and safety measures, in which more emphasis is placed on a specific goal, e.g., improving mobility. This approach is detailed further in Sinha and Labi (2007). For example, given a list of 
freight infrastructure needs, for each performance measure, the "best" measured value would be assigned a value of 1 , and the "worst" measured value would be assigned the value of 5 , and each measure in between would be scaled accordingly.

For instances where not all identified needs contained values for all performance measures, a value might be estimated using professional judgment. Less preferably, a default neutral value of 3 for a scale of 1 to 5 might be assigned for missing values.

Note that when an agency wishes to emphasize certain values more than others, to accomplish specified mobility or safety-related objectives, for example, the scale of those values might be adjusted accordingly by multiplying by a constant or using a larger scale.

A sample of how the freight module could function is given in Table 2, and will be demonstrated further in the concept demonstrations in Section 7. This table gives an example where five performance measures (i.e., PM 1, PM 2, PM 3, PM 4, PM 5) are given for three identified needs (i.e., Route 1, Route 2, and Route 3). The performance measures are rated accordingly on a scale of 1 to 5 with the "best" measures receiving a 1.0 rating, and the "worst" measures receiving a 5.0 rating, unknown measures would be assigned a 3.0, and remaining measures being interpolated.

Table 2. Demonstration of freight module with sample values of expected improvement

\begin{tabular}{|c|c|c|c|c|}
\hline \multicolumn{2}{|c|}{ Corridor with Identified Need for Improvement: } & Route 1 & Route 2 & Route 3 \\
\hline \multirow{5}{*}{ 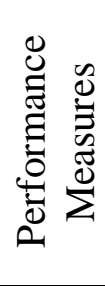 } & PM 1: Structural Integrity & 0.6 & 0.9 & 1.4 \\
\hline & PM 2: Pavement Quality & 190 & 103 & 84 \\
\hline & PM 3: Annual Truck Crashes & 5 & 3 & 4 \\
\hline & PM 4: Daily Excess Truck Costs & 1800 & 2500 & 2400 \\
\hline & PM 5: Daily Economic Inefficiencies & 2000 & 2600 & 2700 \\
\hline \multirow{5}{*}{ 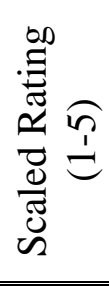 } & PM 1: Structural Integrity & 1.0 & 2.5 & 5.0 \\
\hline & PM 2: Pavement Quality & 5.0 & 1.7 & 1.0 \\
\hline & PM 3: Annual Truck Crashes & 5.0 & 1.0 & 3.0 \\
\hline & PM 4: Daily Excess Truck Costs & 1.0 & 5.0 & 4.4 \\
\hline & PM 5: Daily Economic Inefficiencies & 1.0 & 4.4 & 5.0 \\
\hline \multicolumn{2}{|r|}{ Sum } & 13.0 & 14.6 & 18.4 \\
\hline \multicolumn{2}{|r|}{ Rank } & 3 & 2 & 1 \\
\hline
\end{tabular}




\section{CHAPTER 7: TASK 5 - CONDUCT CONCEPT DEMONSTRATIONS}

In this section, the methodology, as described in previous sections, shown in Figure 1 and Figure 2 above and detailed in Appendix A, is demonstrated for two case study corridors in Virginia: U.S. 460 and U.S. 29. Both concept demonstrations weigh the prospects of building new highway infrastructure and capacity against conditions on the existing roadways. The example contained in Appendix A utilizes a much smaller (and sample) dataset to allow for more step-by-step explanations and visualization of the data tables that is not possible here, given the size of the dataset used for the two concept demonstrations presented below.

Specifically, the first concept demonstration investigates the potential economic impact of a new tolled expressway roughly paralleling U.S. 460 from Suffolk to Petersburg in eastern Virginia. The second concept demonstration examines the economic impact to areas within the U.S. 29 corridor of a new bypass around a heavily developed area on the north side of Charlottesville.

\subsection{Developing the Inoperability Input-Output Model}

The steps described in this section are based on the methodology presented in Figure 4 below, and more specifically described in Appendix A. "Make" and "use" tables (which respectively show monetary values of column commodities produced by various row industries, and monetary values of row commodities consumed by various column industries) were obtained from the BEA. These tables, as well as all the calculated tables described below derived, are shown in Appendix B. 


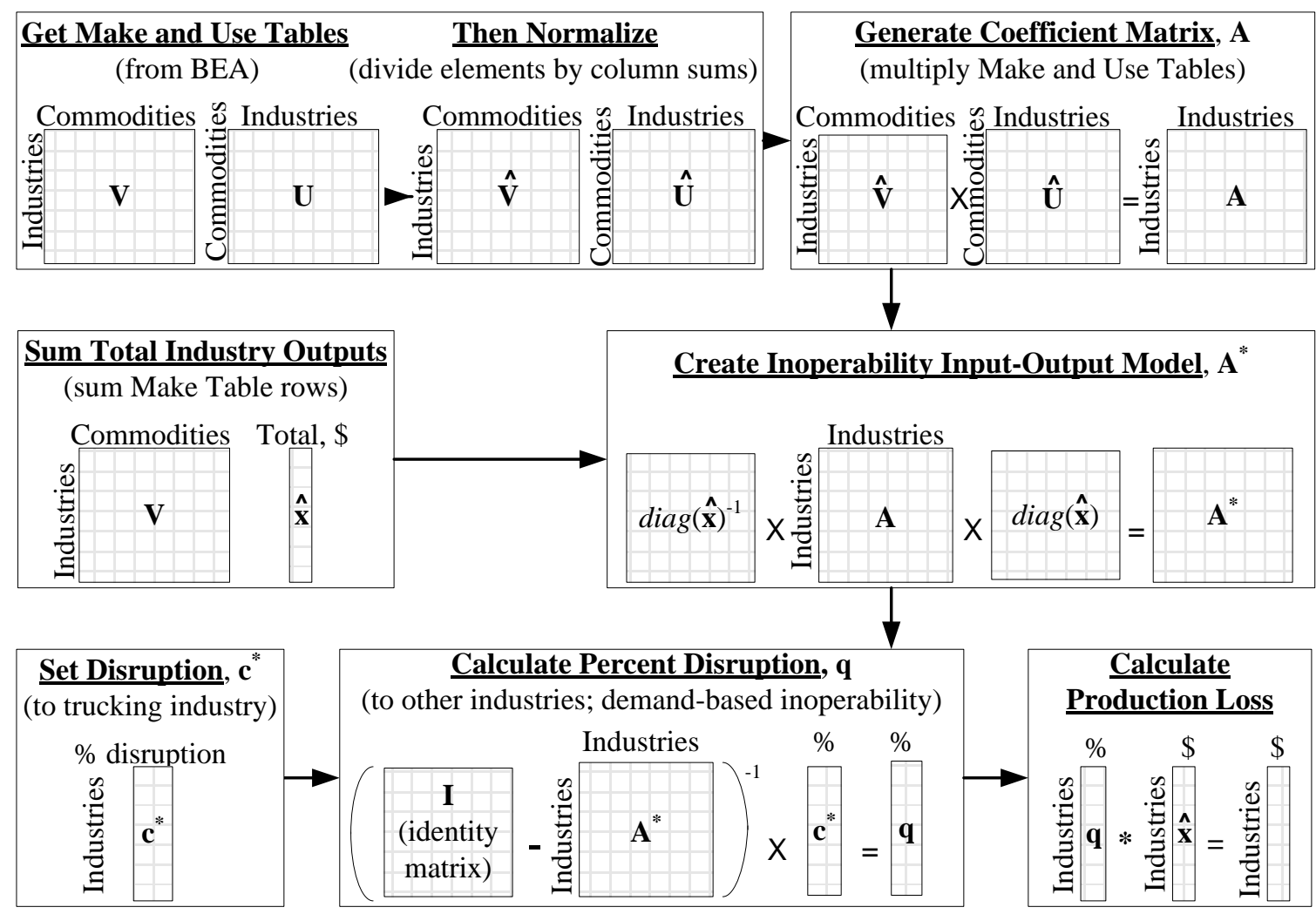

Figure 4. Steps for development of inoperability input-output model and calculation of impacts of an industry disruption (e.g., trucking) to other industrial sectors

Following the procedure more specifically described in Appendix A, the "make" and "use" tables were normalized and multiplied to create an industry-by-industry technical coefficient matrix, $\mathbf{A}$, which gives the proportion of industry $i$ inputs to $j$ relative to the total production output of industry $j$.

Next, the total industry outputs, that is, the "normal" total production vector $\hat{\mathbf{x}}$ were calculated by multiplying the "make" table with a unity vector (whose elements are all ones and is also known as a summation vector).

Using these input-output tables, a demand-based model, the inoperability inputoutput model, was derived. A complete disruption to the trucking sector $\left(\mathbf{c}^{*}=-1\right.$, i.e., $100 \%$ for the trucking sector) reveals the assumptions made by the inoperability inputoutput model in regards to the reliance of each industry on the trucking sector, specifically as it relates to infrastructure performance, i.e., highway infrastructure that includes roads and bridges. This follows the work of Crowther et al. (2004) where trucking sector disruptions in the inoperability input-output model were directly linked to highway infrastructure performance in the context of terrorism.

Table 3 shows the percent disruption of each industry due to the complete disruption of the trucking sector, as well as the dollar loss (in millions of dollars) that each industry would incur. Further reflection on various industry relationships with a trucking sector disruption will be discussed further in Section 8.2 Conclusions. 
Table 3. National Impact to BEA industries with a $100 \%$ disruption to the trucking sector

\begin{tabular}{|c|c|c|c|}
\hline Industry & c* & $\begin{array}{l}\% \text { Industry } \\
\text { Disruption }\end{array}$ & $\begin{array}{l}\text { Dollar Loss } \\
(\text { million } \$)\end{array}$ \\
\hline Farms & 0 & 0.15 & 471 \\
\hline Forestry, fishing, and related activities & 0 & 0.12 & 72 \\
\hline Oil and gas extraction & 0 & 9.52 & 26,000 \\
\hline Mining, except oil and gas & 0 & 0.25 & 193 \\
\hline Support activities for mining & 0 & 0.26 & 327 \\
\hline Utilities & 0 & 0.99 & 4606 \\
\hline Construction & 0 & 0.50 & 6508 \\
\hline Food and beverage and tobacco products & 0 & 0.23 & 1650 \\
\hline Textile mills and textile product mills & 0 & 0.15 & 98 \\
\hline Apparel and leather and allied products & 0 & 0.05 & 15 \\
\hline Wood products & 0 & 0.21 & 211 \\
\hline Paper products & 0 & 0.63 & 1047 \\
\hline Printing and related support activities & 0 & 0.40 & 409 \\
\hline Petroleum and coal products & 0 & 11.51 & 67,706 \\
\hline Chemical products & 0 & 2.33 & 15,115 \\
\hline Plastics and rubber products & 0 & 1.72 & 3555 \\
\hline Nonmetallic mineral products & 0 & 0.28 & 327 \\
\hline Primary metals & 0 & 1.55 & 3648 \\
\hline Fabricated metal products & 0 & 1.84 & 5897 \\
\hline Machinery & 0 & 0.70 & 2244 \\
\hline Computer and electronic products & 0 & 0.66 & 2578 \\
\hline Electrical equipment, appliances, and components & 0 & 0.65 & 798 \\
\hline Motor vehicles, bodies and trailers, and parts & 0 & 3.60 & 17,373 \\
\hline Other transportation equipment & 0 & 0.11 & 247 \\
\hline Furniture and related products & 0 & 0.05 & 39 \\
\hline Miscellaneous manufacturing & 0 & 0.16 & 244 \\
\hline Wholesale trade & 0 & 6.30 & 80,226 \\
\hline Retail trade & 0 & 1.67 & 24,272 \\
\hline Air transportation & 0 & 0.60 & 898 \\
\hline Rail transportation & 0 & 1.01 & 700 \\
\hline Water transportation & 0 & 0.10 & 37 \\
\hline Truck transportation & -1 & 114.28 & 313,551 \\
\hline Transit and ground passenger transportation & 0 & 0.05 & 16 \\
\hline Pipeline transportation & 0 & 0.26 & 88 \\
\hline Other transportation and support activities & 0 & 5.10 & 6790 \\
\hline Warehousing and storage & 0 & 2.43 & 1217 \\
\hline Publishing industries (includes software) & 0 & 0.55 & 1665 \\
\hline Motion picture and sound recording industries & 0 & 0.18 & 174 \\
\hline Broadcasting and telecommunications & 0 & 3.66 & 30,050 \\
\hline Information and data processing services & 0 & 0.89 & 1645 \\
\hline
\end{tabular}




\begin{tabular}{|l|r|r|r|}
\hline Industry & & $\begin{array}{l}\text { \% Industry } \\
\mathbf{c}^{*}\end{array}$ & $\begin{array}{l}\text { Dollar Loss } \\
\text { Disruption }\end{array}$ \\
\hline Federal Reserve banks, credit intermediation, \& related activities & 0 & 2.65 & 20,722 \\
\hline Securities, commodity contracts, and investments & 0 & 0.98 & 4648 \\
\hline Insurance carriers and related activities & 0 & 2.08 & 14,147 \\
\hline Funds, trusts, and other financial vehicles & 0 & 0.04 & 49 \\
\hline Real estate & 0 & 3.08 & 75,452 \\
\hline Rental and leasing services and lessors of intangible assets & 0 & 2.54 & 7282 \\
\hline Legal services & 0 & 0.91 & 2534 \\
\hline Miscellaneous professional, scientific \& technical services & 0 & 4.93 & 56,514 \\
\hline Computer systems design and related services & 0 & 0.90 & 1941 \\
\hline Management of companies and enterprises & 0 & 3.35 & 15,141 \\
\hline Administrative and support services & 0 & 2.23 & 13,813 \\
\hline Waste management and remediation services & 0 & 0.58 & 434 \\
\hline Educational services & 0 & 0.12 & 251 \\
\hline Ambulatory health care services & 0 & 0.07 & 511 \\
\hline Hospitals and nursing and residential care facilities & 0 & 0.01 & 98 \\
\hline Social assistance & 0 & 0.00 & 4 \\
\hline Performing arts, spectator sports, museums, \& related activities & 0 & 0.20 & 198 \\
\hline Amusements, gambling, and recreation industries & 0 & 0.04 & 42 \\
\hline Accommodation & 0 & 0.23 & 463 \\
\hline Food services and drinking places & 0 & 0.36 & 1872 \\
\hline Other services, except government & 0 & 2.24 & 13,679 \\
\hline Federal government enterprises & 0 & 0.31 & 313 \\
\hline Federal general government & 0 & 0.04 & 357 \\
\hline State and local government enterprises & 0 & 0.68 & 1582 \\
\hline State and local general government & 0 & 0.29 & 5235 \\
\hline
\end{tabular}

To facilitate analysis here, a unit value of $\$ 1$ to the trucking sector is used in the inoperability input-output model to represent changes in truck user costs caused by a disruption (or an improvement). The inoperability input-output model then shows sector disruptions that are proportional to the value of the original disruption, which is possible since the input-output model is linear; thus, the relative economic impact to a sector is based on an impact to the trucking sector (for example, a $\$ 1$ disruption to the trucking sector will disrupt $\$ .05$ of sector $\mathrm{A}, \$ .25$ of sector $\mathrm{B}$, etc.). Note that the unit disruption is not intended to represent any specific incident or congestion for any specific point; instead, it is used to show the various industrial sectors' dependence on the trucking sector for the study area. Thus, for any given incidents or congestion on specific highways in Virginia, it can be known what sectors will be most impacted by a disruption. Also, since the input-output model is linear, these relative values can be multiplied by a specific value representing a trucking disruption event to show indirect impacts for an event.

For these concept demonstrations, ten Freight Analysis Framework commodities were selected for analysis, based on their top rankings as Virginia critical commodities handled by truck in the state according to the Virginia Statewide Multimodal Freight 
Study, as shown in Table 4 (Cambridge Systematics, 2010).

Table 4. Virginia's Top Critical Commodities Handled by Truck

\begin{tabular}{|l|r|r|c|}
\hline $\begin{array}{l}\text { Leading Virginia Truck Tonnage } \\
\text { Commodities (2004) }\end{array}$ & $\begin{array}{c}\text { Truck- } \\
\text { hauled } \\
\text { Tonnage }\end{array}$ & $\begin{array}{c}\text { Truck } \\
\text { Mode } \\
\text { Share, \% } \\
\text { Tonnage }\end{array}$ & $\begin{array}{c}\text { Concept } \\
\text { Demonstration } \\
\text { Inclusion }\end{array}$ \\
\hline Nonmetallic Minerals & $99,947,446$ & $89 \%$ & $\checkmark$ \\
\hline Secondary Traffic (warehouse dist.) & $62,524,254$ & $100 \%$ & \\
\hline Clay, Concrete, Glass, or Stone & $36,171,451$ & $92 \%$ & $\checkmark$ \\
\hline Lumber or Wood Products & $32,867,249$ & $95 \%$ & $\checkmark$ \\
\hline Food or Kindred Products & $31,112,374$ & $93 \%$ & $\checkmark$ \\
\hline Petroleum or Coal Products & $27,883,789$ & $80 \%$ & \\
\hline Chemicals or Allied Products & $24,248,272$ & $86 \%$ & \\
\hline Pulp, Paper, or Allied Products & $9,957,320$ & $80 \%$ & \\
\hline Transportation Equipment & $9,922,172$ & $87 \%$ & \\
\hline Farm Products & $9,728,832$ & $81 \%$ & \\
\hline Sarc: Virgnia Stawide Mutimo & & & \\
\hline
\end{tabular}

Source: Virginia Statewide Multimodal Freight Study (Cambridge Systematics, 2010)

These selected commodities are represented by disparate Freight Analysis Framework commodities and BEA industries used in the input-output model, as shown in Table 5. Examples of products that are classified as these commodities are listed in Table 6. Also shown are values from the inoperability input-output model relating to the percent disruption and relative dollar loss for a unit disruption to the trucking sector for BEA industries, and the relative dollar loss values for Freight Analysis Framework commodities used in the concept demonstrations. The connections shown in Table 5 between BEA industries and Freight Analysis Framework commodities are based on the relations used for the development of the Freight Analysis Framework model (Southworth, et al., 2011).

Because it is representative of the entire state of Virginia, this developed inoperability input-output model is applicable for both concept demonstrations examples presented below. 
Table 5. Selected Freight Analysis Framework Commodities and BEA Industries for the Concept Demonstrations, and relative economic impact values from the inoperability input-output model

\begin{tabular}{|c|c|c|c|c|}
\hline $\begin{array}{c}\text { Freight } \\
\text { Analysis } \\
\text { Framework } \\
\text { Commodity } \\
\end{array}$ & $\begin{array}{c}\text { BEA Industry } \\
\text { (inoper. input-output model) }\end{array}$ & $\begin{array}{l}\text { Percent } \\
\text { disruption } \\
(\mathrm{q})\end{array}$ & $\begin{array}{l}\$ \text { loss, } \\
\text { ratio }\end{array}$ & $\begin{array}{c}\text { Derived } \\
\text { Commodity } \\
\$ \text { loss ratio }\end{array}$ \\
\hline \multirow{2}{*}{ Cereal grains } & Farms & $7.77 \mathrm{E}-11$ & 0.00153 & \multirow{2}{*}{0.00193} \\
\hline & Food and beverage and tobacco products & $1.15 \mathrm{E}-10$ & 0.00233 & \\
\hline \multirow{2}{*}{ Meat/seafood } & Farms & 7.77E-11 & 0.00153 & \multirow{2}{*}{0.00193} \\
\hline & Food and beverage and tobacco products & $1.15 \mathrm{E}-10$ & 0.00233 & \\
\hline \multirow{2}{*}{$\begin{array}{l}\text { Milled grain } \\
\text { prods. }\end{array}$} & Farms & $7.77 \mathrm{E}-11$ & 0.00153 & \multirow{2}{*}{0.00193} \\
\hline & Food and beverage and tobacco products & $1.15 \mathrm{E}-10$ & 0.00233 & \\
\hline \multirow{2}{*}{$\begin{array}{l}\text { Other } \\
\text { foodstuffs }\end{array}$} & Farms & $7.77 \mathrm{E}-11$ & 0.00153 & \multirow{2}{*}{0.00193} \\
\hline & Food and beverage and tobacco products & $1.15 \mathrm{E}-10$ & 0.00233 & \\
\hline \multirow{2}{*}{$\begin{array}{l}\text { Building } \\
\text { stone }\end{array}$} & Mining, except oil and gas & $1.25 \mathrm{E}-10$ & 0.00245 & \multirow{2}{*}{0.00250} \\
\hline & Support activities for mining & $1.31 \mathrm{E}-10$ & 0.00257 & \\
\hline \multirow{2}{*}{$\begin{array}{l}\text { Natural } \\
\text { sands }\end{array}$} & Mining, except oil and gas & $1.25 \mathrm{E}-10$ & 0.00245 & \multirow{2}{*}{0.00250} \\
\hline & Support activities for mining & $1.31 \mathrm{E}-10$ & 0.00257 & \\
\hline \multirow{2}{*}{ Gravel } & Mining, except oil and gas & $1.25 \mathrm{E}-10$ & 0.00245 & \multirow{2}{*}{0.00250} \\
\hline & Support activities for mining & $1.31 \mathrm{E}-10$ & 0.00257 & \\
\hline \multirow{2}{*}{$\begin{array}{l}\text { Nonmetallic } \\
\text { minerals }\end{array}$} & Mining, except oil and gas & $1.25 \mathrm{E}-10$ & 0.00245 & \multirow{2}{*}{0.00250} \\
\hline & Support activities for mining & $1.31 \mathrm{E}-10$ & 0.00257 & \\
\hline \multirow{2}{*}{ Logs } & Forestry, fishing, and related activities & $6.06 \mathrm{E}-11$ & 0.00118 & \multirow{2}{*}{0.00165} \\
\hline & Wood products & $1.09 \mathrm{E}-10$ & 0.00213 & \\
\hline \multirow{2}{*}{$\begin{array}{l}\text { Wood } \\
\text { products }\end{array}$} & Furniture and related products & $2.49 \mathrm{E}-11$ & 0.00049 & \multirow{2}{*}{0.00130} \\
\hline & Wood products & $1.09 \mathrm{E}-10$ & 0.00213 & \\
\hline
\end{tabular}


Table 6. Example products of Freight Analysis Framework Commodities

\begin{tabular}{|c|c|}
\hline Freight Analysis Framework Commodity & Examples of Products \\
\hline Cereal grains & $\begin{array}{l}\text { Wheat, Corn (except sweet corn), Rye, } \\
\text { Barley, Oats }\end{array}$ \\
\hline Meat/seafood & $\begin{array}{l}\text { Fresh or chilled poultry, beef, pork fish, } \\
\text { and aquatic invertebrates }\end{array}$ \\
\hline Milled grain prods. & $\begin{array}{l}\text { Wheat flour, milled rice, corn flour, pasta, } \\
\text { baked snack foods, baked products - } \\
\text { frozen, perishable, or dry, }\end{array}$ \\
\hline Other foodstuffs & $\begin{array}{l}\text { Dairy products - milk and cream, cheese } \\
\text { and curds, and ice cream; coffee, tea, and } \\
\text { spices; processed or prepared vegetables, } \\
\text { fruit, or nuts - potato chips, jams and } \\
\text { jellies, frozen fruit and vegetable juices; } \\
\text { sugars; and carbonated soft drinks }\end{array}$ \\
\hline Building stone & Monumental or building stone \\
\hline Natural sands & Silica sands and quartz \\
\hline Gravel & $\begin{array}{l}\text { Limestone flux, agricultural limestone, and } \\
\text { other gravel and crushed stone }\end{array}$ \\
\hline Nonmetallic minerals & $\begin{array}{l}\text { Table salt, sulfur, dolomite, natural calcium } \\
\text { phosphates, clays, and asbestos }\end{array}$ \\
\hline Logs & Logs for pulping, lumber, and fuel \\
\hline Wood products & $\begin{array}{l}\text { Wood chips or particles, treated and } \\
\text { untreated lumber, shingles or shakes, } \\
\text { plywood, and fiberboard }\end{array}$ \\
\hline
\end{tabular}

Source: BTS and U.S. Census Bureau, 2011.

\subsection{Gathering Safety Data}

Baseline safety data was gathered to use for both concept demonstrations examples. All of this data is publically available through VDOT (2012-a). Both concept demonstrations examples are included in the Virginia Primary Roadway system and so this statewide data was used for a baseline for current conditions. Interstate highway crash data was selected to assist with estimating crashes on the proposed improved roadways in the concept demonstrations, since each of these are to be limited access facilities built to similar standards. Because crash data includes several years of latency, the latest available data is only through 2007.

In order to normalize crash data, 2005-2007 daily VMT data was gathered for each Federal vehicle class, as shown in Table 7 for both primary and interstate roadways. Daily VMT was summed for vehicle classes 5-14, which represent daily truck VMT (ODOT, 2012), as shown below, to discern the total daily truck VMT for each year. This value was multiplied by 365 to have a value of total annual truck VMT per year for both primary and interstate roadways. 
Table 7. Daily Truck Vehicle-Miles Traveled by Federal Vehicle Class on Virginia Primary and Interstate Roadways

\begin{tabular}{|c|c|c|c|c|c|c|c|}
\hline \multirow{2}{*}{$\begin{array}{c}\text { Federal } \\
\text { Vehicle } \\
\text { Class }\end{array}$} & \multirow{2}{*}{$\begin{array}{l}\text { Federal Vehicle } \\
\text { Class Description }\end{array}$} & \multicolumn{3}{|c|}{ Primary Roadways } & \multicolumn{3}{|c|}{ Interstate System } \\
\hline & & 2005 & 2006 & 2007 & 2005 & 2006 & 2007 \\
\hline 5 & $\begin{array}{l}\text { 2-axle, 6-tire, } \\
\text { single unit trucks }\end{array}$ & 819005 & 817560 & 840478 & 514412 & 465642 & 444266 \\
\hline 6 & $\begin{array}{l}\text { 3-axle, single-unit } \\
\text { trucks }\end{array}$ & 620369 & 625110 & 625405 & 394680 & 355206 & 347305 \\
\hline 7 & $\begin{array}{l}4 \text { or more axle, } \\
\text { single-unit trucks }\end{array}$ & 157314 & 162354 & 161749 & 71596 & 69916 & 74096 \\
\hline 8 & $\begin{array}{l}4 \text { or fewer axle, } \\
\text { single-trailer trucks }\end{array}$ & 352059 & 341296 & 316065 & 295770 & 364727 & 429139 \\
\hline 9 & $\begin{array}{l}\text { 5-axle, single- } \\
\text { trailer trucks }\end{array}$ & || 2467536 & 2655747 & 2605762 & 6748732 & 6850638 & 6932382 \\
\hline 10 & $\begin{array}{l}6 \text { or more axle, } \\
\text { single trailer trucks }\end{array}$ & 68557 & 83784 & 85092 & 83064 & 80175 & 84523 \\
\hline 11 & $\begin{array}{l}5 \text { or fewer axle, } \\
\text { multi-trailer trucks }\end{array}$ & 66048 & 71646 & 72254 & 293672 & 299597 & 302182 \\
\hline 12 & $\begin{array}{l}\text { 6-axle, multi-trailer } \\
\text { trucks }\end{array}$ & 14890 & 15620 & 14280 & 106773 & 104581 & 98867 \\
\hline 13 & $\begin{array}{l}7 \text { or more axle } \\
\text { multi-trailer trucks }\end{array}$ & 574 & 201 & 167 & 591 & 525 & 616 \\
\hline \multicolumn{2}{|c|}{ Total Daily Truck VMT } & 4566352 & 4773318 & 4721252 & || 8509290 & 8591007 & 8713376 \\
\hline \multicolumn{2}{|c|}{$\begin{array}{r}\text { Total Annual Truck VMT } \\
\text { (x100 million) }\end{array}$} & 16.7 & 17.4 & 17.2 & 31.1 & 31.4 & 31.8 \\
\hline
\end{tabular}

Source: VDOT, 2012-b.

Next, truck crash statistics for 2005-2007 were gathered for both primary and interstate roadways for the entire state of Virginia, and are organized by crash type in Table 8. In order to more easily compare the number of crashes across multiple years while still accounting for severity, a method from Garber and Hoel (2009) was applied that weights fatal, injury, and property damage crashes on a scale of 12:3:1. These values are shown in the bottom row of Table 8 . All values in this table are then averaged across 2005-2007 separately for primary and interstate roadways. 
Table 8. 2005-2007 Truck Crashes on Virginia Primary and Interstate Roadways

\begin{tabular}{|l|c|c|c|c||c|c|c|c|}
\hline \multirow{3}{*}{$\begin{array}{c}\text { Truck Crash } \\
\text { Type }\end{array}$} & \multicolumn{4}{c||}{$\begin{array}{c}\text { All Truck Crashes on } \\
\text { Virginia Primary Roadways }\end{array}$} & \multicolumn{3}{c|}{$\begin{array}{c}\text { All Truck Crashes on the } \\
\text { Interstate System in Virginia }\end{array}$} \\
\cline { 2 - 10 } & 2005 & 2006 & 2007 & $\begin{array}{c}2005-2007 \\
\text { Average }\end{array}$ & 2005 & 2006 & 2007 & $\begin{array}{c}2005-2007 \\
\text { Average }\end{array}$ \\
\hline Fatal Crash & 55 & 48 & 48 & 52 & 28 & 32 & 31 & 30 \\
\hline Persons Killed & 64 & 51 & 57 & 58 & 29 & 38 & 36 & 34 \\
\hline Injury Crash & 1001 & 848 & 795 & 925 & 952 & 919 & 779 & 936 \\
\hline Persons Injured & 1448 & 1220 & 1122 & 1334 & 1446 & 1325 & 1141 & 1386 \\
\hline PDO Crash & 1757 & 1577 & 1412 & 1667 & 1973 & 1790 & 1685 & 1882 \\
\hline Total Crash & 2813 & 2473 & 2255 & 2643 & 2953 & 2741 & 2495 & 2847 \\
\hline $\begin{array}{l}\text { Crash Severity } \\
\text { Number (12:3:1) }\end{array}$ & 5420 & 4697 & 4373 & 5059 & 5165 & 4931 & 4394 & 5048 \\
\hline
\end{tabular}

Source: VDOT, 2012-a.

Truck crash values shown in Table 8 were normalized using the total annual truck VMT values for each year from Table 7. The resultant truck crash rates were divided by 100 million in order to give Truck crash rates per 100 million truck VMT, as depicted in Table 9.

Table 9. 2005-2007 Truck Crash Rates on Virginia Primary and Interstate Roadways

\begin{tabular}{|l|c|c|c|c||c|c|c|c|}
\hline \multirow{2}{*}{$\begin{array}{c}\text { Truck Crash rates } \\
\text { per 100 million } \\
\text { Truck VMT }\end{array}$} & \multicolumn{4}{|c|}{$\begin{array}{c}\text { Truck Crash Rates on Virginia } \\
\text { Primary Roadways }\end{array}$} & \multicolumn{3}{c|}{$\begin{array}{c}\text { Truck Crash Rates on the } \\
\text { Interstate System in Virginia }\end{array}$} \\
\cline { 2 - 10 } & 2005 & 2006 & 2007 & $\begin{array}{c}2005-2007 \\
\text { Average }\end{array}$ & 2005 & 2006 & 2007 & $\begin{array}{c}2005-2007 \\
\text { Average }\end{array}$ \\
\hline Fatal Crash Rate & 3.3 & 2.8 & 2.8 & 2.9 & 0.9 & 1.0 & 1.0 & 1.0 \\
\hline Persons Killed Rate & 3.8 & 2.9 & 3.3 & 3.4 & 0.9 & 1.2 & 1.1 & 1.1 \\
\hline Injury Crash Rate & 60.1 & 48.7 & 46.1 & 51.6 & 30.7 & 29.3 & 24.5 & 30.0 \\
\hline Persons Injured Rate & 86.9 & 70.0 & 65.1 & 74.0 & 46.6 & 42.3 & 35.9 & 44.4 \\
\hline PDO Crash Rate & 105.4 & 90.5 & 81.9 & 92.6 & 63.5 & 57.1 & 53.0 & 60.3 \\
\hline Total Crash Rate & 168.8 & 141.9 & 130.9 & 147.2 & 95.1 & 87.4 & 78.4 & 91.2 \\
\hline $\begin{array}{l}\text { Crash Severity Rate } \\
(12: 3: 1)\end{array}$ & 253.8 & 269.6 & 325.2 & 261.7 & 166.3 & 157.3 & 138.2 & 161.8 \\
\hline
\end{tabular}

\subsection{Concept Demonstration \#1: U.S. 460 Expressway - Hampton Roads to Petersburg, VA}

The U.S. 460 corridor stretches west from Hampton Roads as a four-lane non-divided highway with numerous ground-level crossings, including 12 signalized intersections before connecting with Interstates 295, 95, and 85 in Petersburg, then continuing west into central and western Virginia as a two-lane roadway. The seaports in Hampton Roads generate significant volumes of truck traffic into and out of that area via the primary 
interregional highways of the region, which include Interstate 64, U.S. 13, U.S. 17, U.S. 58, and U.S. 460. Each of the Hampton Roads Bridge-Tunnels, i.e., Interstate 64 and Interstate 664, are severe bottlenecks in the region for north-south traffic in the area. As depicted in Figure 5, while Interstate 64 enters the Hampton Roads area from the northwest as the only limited-access highway for the region, U.S. 460 enters from the west on the south side of Hampton Roads, serving as a bypass to the bridge-tunnels for traffic to destinations on the southern side of the harbor.

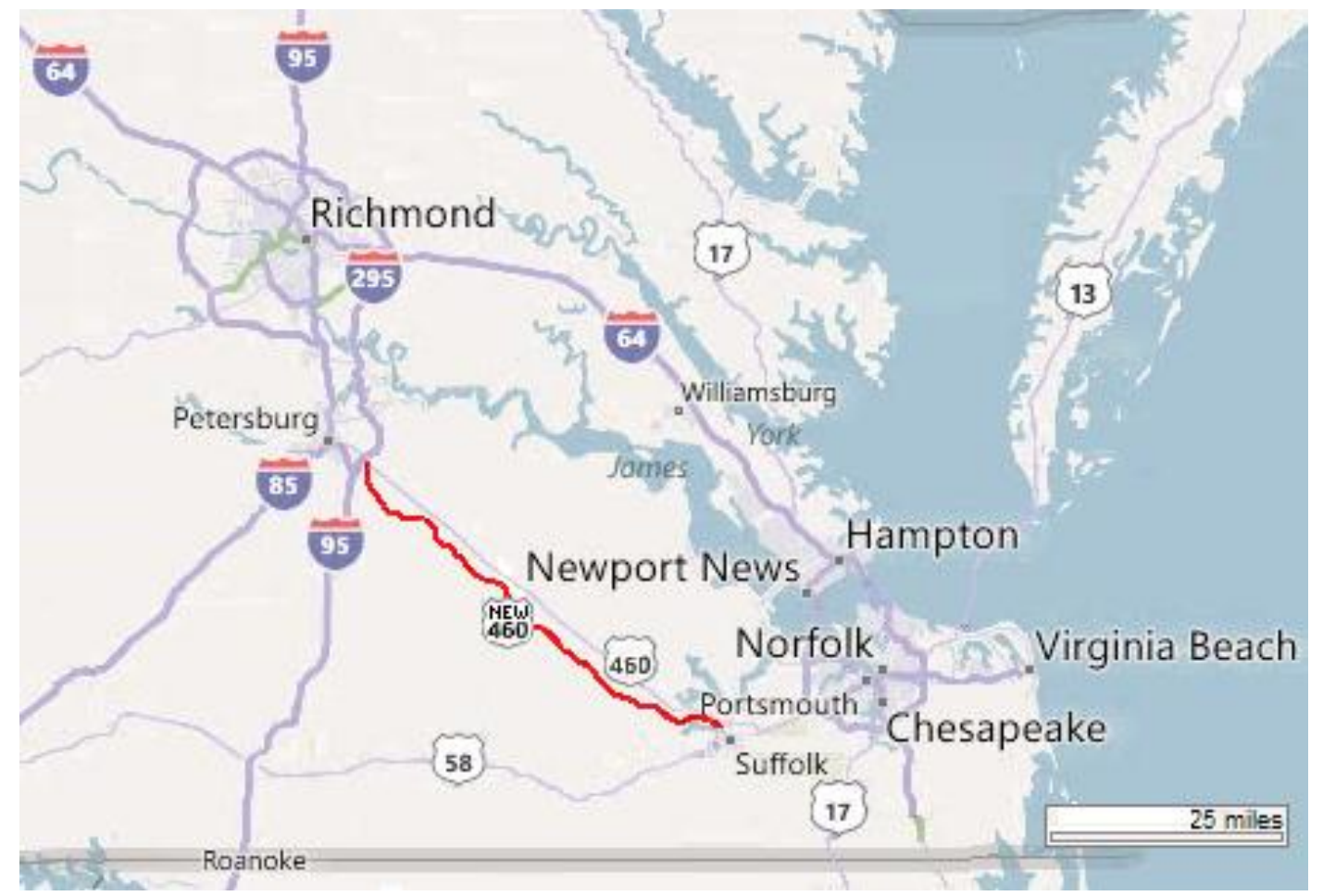

Figure 5. Map of eastern Virginia showing U.S. 460 (existing and proposed "new" in red) and other major routes in the region

As of 2012, the Virginia Department of Transportation (VDOT) continues to explore an agreement to develop a four-lane divided, limited-access tolled expressway that would parallel the existing four-lane U.S. 460 between Suffolk in the east near Hampton Roads to the junction with Interstate 295 in the west near Petersburg. This project is intended to address increased freight volumes and support local economic development plans, as well as address general corridor deficiencies, improve safety, reduce travel delay, and improve hurricane evacuation capabilities (VDOT, 2012-c; FHWA \& VDOT, 2005).

Specifically, travel demand forecasts show increased demand for an improved expressway versus the existing highway in 2026 forecasts, ranging from 160\% to $425 \%$ over existing demand for various segments (FHWA \& VDOT, 2005). While the travel time on the existing highway was 73 minutes in 2003, it is forecast to be 81 minutes and 60 minutes on the existing and proposed highways, respectively, in 2026; in other words, the proposed expressway is projected to have a 21 minute or $26 \%$ travel time savings in 2026 for the length of the route (FHWA \& VDOT, 2005). Truck percentage is also 
expected to increase from $23 \%-30 \%$ in 2003 to $30 \%-36 \%$ in 2026 on the existing highway, or 28\%-38\% on an improved highway in 2026 (FHWA \& VDOT, 2005).

Additionally, the proposed expressway would be a safer facility type than the existing roadway, which has historically had a disproportionately high crash rate for its facility type (FHWA \& VDOT, 2005).

While this 55-mile toll road would provide a better connection to the region, the proposed truck toll is $\$ .21$ per mile ( $\$ 11.72$ for a complete one-way trip), with a 3.5\% annual toll escalation (VDOT, 2012-c).

\subsubsection{Calculating U.S. 460 Economic Importance}

Due to the geographic position of Hampton Roads on the east coast, this study assumed that through traffic on the east-west U.S. 460 would have its origin or destination in the Hampton Roads Freight Analysis Framework region. Freight tonnage origin-destination data retrieved from the FHWA Freight Analysis Framework was organized and sorted into three major geographic groups for route assignment purposes; two individual Freight Analysis Framework regions, Richmond and Remainder of Virginia, were retained as separate groups as shown in Figure 6, due to close proximity to the Hampton Roads Freight Analysis Framework region, for a total of five geographic groups. The three major groupings, shown in Figure 6 alongside the two individual Virginia regions, are likely to have differing route splits between the choices offered by Interstate 64 and U.S. 13, U.S. 17, U.S. 58, and U.S. 460.

Route assignment for the five regions was estimated based on travel time estimations from Google Maps, and empirical knowledge of the quality of the route, i.e., two-lane vs. four-lane vs. four-lane limited access between the Freight Analysis Framework commodity origin-destination pairs. This was validated and further refined by summing kilotons of selected commodities for each route (see Table 10), then comparing the proportional Freight Analysis Framework AADTT, i.e., truck volume, estimations given for those routes, as shown in Table 11. 


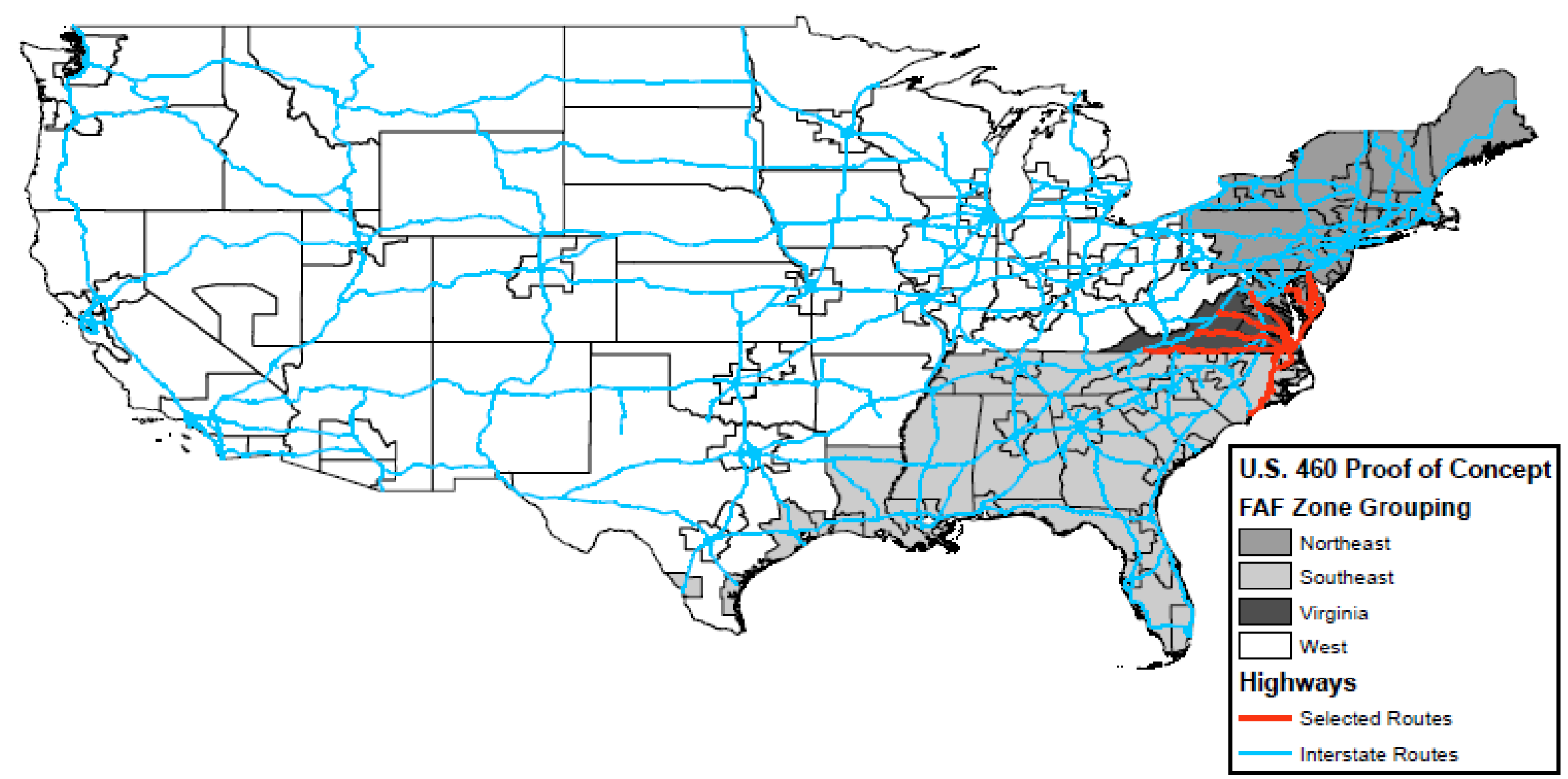

Figure 6. Freight Analysis Framework region groupings for origin-destination route assignment designation to/from the Hampton Roads area given available, selected routes 
Table 10. Kilotons of Commodities by grouped Freight Analysis Framework region

\begin{tabular}{|l|r|r|r|r|r|}
\hline Commodity & North & South & West & Richmond & $\begin{array}{c}\text { Remainder } \\
\text { of Virginia }\end{array}$ \\
\hline Building stone & 44.7 & 24.0 & 19.7 & 15.7 & 2.1 \\
\hline Cereal grains & 127.0 & 216.0 & 213.8 & 354.2 & 147.9 \\
\hline Gravel & 291.7 & 14.2 & 0.2 & 441.9 & 113.2 \\
\hline Logs & 52.6 & 13.1 & 6.6 & 56.1 & 93.9 \\
\hline Meat/seafood & 224.5 & 404.3 & 137.5 & 31.0 & 65.7 \\
\hline Milled Grain Products & 57.8 & 77.9 & 37.2 & 9.9 & 0.5 \\
\hline Natural Sands & 2.3 & 658.1 & 26.2 & 8.3 & 4.5 \\
\hline Nonmetallic minerals & 281.6 & 599.0 & 25.7 & 74.2 & 10.3 \\
\hline Other foodstuffs & 771.1 & 330.2 & 279.8 & 260.8 & 254.5 \\
\hline Wood Products & 367.0 & 703.3 & 234.4 & 200.0 & 446.1 \\
\hline \hline Total for Region & 2220.4 & 3040.2 & 981.2 & 1452.0 & 1138.7 \\
\hline
\end{tabular}

Table 11. Route assignment estimations by grouped Freight Analysis Framework region

\begin{tabular}{|c|c|c|c|c|c|c|c|c|}
\hline \multirow[b]{2}{*}{ Route } & \multicolumn{2}{|c|}{ AADTT 2007} & \multicolumn{6}{|c|}{$\begin{array}{l}\text { Grouped region origin-destination direction from } \\
\text { Hampton Roads ( } \% \text { of total KiloTons) }\end{array}$} \\
\hline & Volume & $\begin{array}{l}\% \text { of } \\
\text { total }\end{array}$ & North & West & South & Richmond & $\begin{array}{c}\text { Virginia } \\
\text { remainder }\end{array}$ & $\begin{array}{l}\text { Route } \\
\text { Total }\end{array}$ \\
\hline Interstate 64 & 3870 & 34.9 & 12.2 & 6.4 & 1.0 & 10.9 & 4.1 & 34.6 \\
\hline U.S. 13 (north) & 743 & 6.7 & 5.6 & 0 & 0 & 0 & 1.1 & 6.7 \\
\hline U.S. 13 (south) & 262 & 2.4 & 0 & 0 & 2.4 & 0 & 0 & 2.4 \\
\hline U.S. 17 (north) & 172 & 1.5 & 0.9 & 0.4 & 0 & 0 & 0.2 & 1.5 \\
\hline U.S. 17 (south) & 1224 & 11.0 & 0 & 0 & 11.0 & 0 & 0 & 11.0 \\
\hline U.S. 58 & 2562 & 23.1 & 0 & 1.1 & 17.6 & 0 & 4.1 & 22.8 \\
\hline U.S. 460 & 2271 & 20.5 & 6.1 & 3.2 & 2.1 & 5.4 & 4.1 & 20.9 \\
\hline Total & 11,104 & 100 & 24.9 & 11.0 & 34.1 & 16.3 & 13.7 & 100 \\
\hline
\end{tabular}

It might be expected that a new, improved expressway paralleling U.S. 460 would serve not only the truck traffic on the existing route, but also attract truck traffic from other, more congested neighboring routes I-64 and U.S. 58, particularly trucks that might have to cross one of the Hampton Roads Bridge-Tunnels to reach their origin or destination. However, for the purposes of this study, despite the potential benefit that existing truck traffic on I-64 and U.S. 58 might derive from the new expressway, only existing truck volumes are analyzed. For instance, in uncongested conditions, I-64 will still provide a faster travel time than the proposed U.S. 460 expressway to northern region destinations; however, given congestion at the Hampton Roads Bridge-Tunnels, the U.S. 460 expressway may offer a shorter travel time. Accurately determining the specific volume or proportionate of truck traffic that not only might experience faster travel times on U.S. 460 given congestion levels at the bridge-tunnels, but also would make that choice as a result of traveler information would be difficult and was not estimated for the purposes of this demonstration. The percentages in Table 11 above 
were applied to the commodity tonnage values in Table 10 to give the commodity tonnage values for this concept demonstration in Table 12. The values generated from the inoperability input-output model are applied to this commodity tonnage to provide values of economic importance, which are shown in Table 12; as highlighted in bold text, the value of economic importance for U.S. 460 is 3.560 .

Table 12. Total Commodity Tonnage by Route for U.S. 460 Concept Demonstration

\begin{tabular}{|l|c|c|c|c|c|c|}
\hline \multirow{2}{*}{ Commodity } & \multicolumn{4}{|c|}{ Kilotons by route } & \multicolumn{3}{c|}{$\begin{array}{c}\text { Input-Output Economic } \\
\text { Importance by route }\end{array}$} \\
\cline { 2 - 7 } Building stone & I-64 & U.S. 460 & U.S. 58 & I-64 & U.S. 460 & U.S. 58 \\
\hline Cereal grains & 45.2 & 24.0 & 14.9 & 0.113 & 0.060 & 0.037 \\
\hline Gravel & 473.4 & 268.9 & 176.8 & 0.914 & 0.519 & 0.341 \\
\hline Logs & 472.7 & 254.1 & 41.5 & 1.186 & 0.637 & 0.104 \\
\hline Meat/seafood & 95.9 & 62.7 & 35.7 & 0.159 & 0.104 & 0.059 \\
\hline Milled Grain Products & 242.6 & 149.7 & 241.9 & 0.469 & 0.289 & 0.467 \\
\hline Natural Sands & 43.1 & 33.1 & 43.9 & 0.114 & 0.064 & 0.085 \\
\hline Nonmetallic minerals & 224.1 & 140.9 & 315.0 & 0.562 & 0.353 & 0.790 \\
\hline Other foodstuffs & 801.6 & 454.2 & 274.3 & 1.548 & 0.877 & 0.530 \\
\hline Wood Products & 605.2 & 401.9 & 520.4 & 0.790 & 0.525 & 0.680 \\
\hline \hline Total for Region & 3062.9 & 1841.7 & 2008.3 & 5.963 & $\mathbf{3 . 5 6 0}$ & 3.956 \\
\hline \hline $\begin{array}{l}\text { Ratio with I-64 } \\
\text { Regional Total }\end{array}$ & 1 & 0.6013 & 0.656 & 1.000 & 0.597 & 0.663 \\
\hline
\end{tabular}

\subsubsection{Calculating U.S. 460 Excess Trucking Costs}

Excess trucking costs for mobility and safety are calculated for this concept demonstration based on travel time savings and potential truck crash reduction for a scenario comparing the existing U.S. 460 with the projected benefits of a completed U.S. 460 expressway.

A conservative estimate of total excess trucking costs due to travel time savings can be derived using 2007 AADTT values from the Freight Analysis Framework and the U.S. 460 Environmental Impact Statement estimates of travel times. An hourly value of commercial vehicle time to calculate excess costs is $\$ 105.67$ as reported in TTI's Urban Mobility Report (Schrank et al., 2010). Assume that with existing conditions, the new expressway would have a travel time of 60 minutes versus 73 minutes for the existing route, as reported in the U.S. 460 Environmental Impact Statement. Thus, trucks incur costs due to an additional 13 minutes of travel, resulting in an excess trucking cost of almost \$23 per truck, or using the 2007 AADTT of 2271 trucks, a total excess trucking cost of nearly $\$ 52,000$ per day, totaling over $\$ 19$ million annually for only travel time savings on the new expressway alone.

Excess trucking costs can similarly be calculated from other measures, such as projected safety benefits. Crash data on a compact disc (CD) for the entire state of Virginia for 2005-2010 were obtained directly from the VDOT Central Office, by request. Crash data on this $\mathrm{CD}$ were organized in a series of tables. In order to glean 
relevant truck crash data specifically for the U.S. 460 study corridor, two tables (i.e., "crash document" and "crash vehicle") from this CD had to be joined by the crash document number. Several filters were applied to this data. Data were limited to crashes that:

- Include vehicle classes that identify trucks;

- Occurred on U.S. 460; and

- Occurred between Latitude/Longitude points of either end of the study area (37.188083,-77.323837 and 36.767225,-76.603681), or

- Occurred between state designated mileposts of the study area (324.09 to 373.89). Note that both latitude/longitude coordinates and mileposts were used to locate relevant crash data since neither of these fields was consistently completed for all crash data for all years. This raw crash data for the U.S. 460 study corridor is presented in Table C-1 of Appendix C. The filtered crash data relevant to the U.S. 460 study corridor for years 2005-2010 is presented in Table 13.

Table 13. 2005-2010 Truck Crashes by Crash Type on U.S. 460 Study Corridor

\begin{tabular}{|l|c|c|c|c|c|c|c|}
\hline \multirow{2}{*}{$\begin{array}{c}\text { Truck Crash } \\
\text { Type }\end{array}$} & \multicolumn{6}{|c|}{ Truck Crashes on U.S. 460 Study Corridor } \\
\cline { 2 - 9 } & 2005 & 2006 & 2007 & 2008 & 2009 & 2010 & $\begin{array}{c}\text { 2005-2010 } \\
\text { Average }\end{array}$ \\
\hline Fatal Crash & 1 & 4 & 4 & 4 & 0 & 3 & 2.7 \\
\hline Persons Killed & 3 & 4 & 4 & 4 & 0 & 3 & 3.0 \\
\hline Injury Crash & 13 & 15 & 12 & 10 & 13 & 6 & 11.5 \\
\hline Persons Injured & 16 & 22 & 20 & 11 & 15 & 8 & 15.3 \\
\hline PDO Crash & 19 & 33 & 22 & 10 & 32 & 11 & 21.2 \\
\hline Total Crash & 33 & 52 & 38 & 24 & 45 & 20 & 35.3 \\
\hline $\begin{array}{l}\text { Crash Severity } \\
\text { Number (12:3:1) }\end{array}$ & 70 & 126 & 106 & 88 & 71 & 65 & 87.7 \\
\hline
\end{tabular}

To normalize the data, the distance of the existing segment to be replaced was determined to be 50 miles based on the farthest endpoints of crash data. The 2007 AADTT of the existing segment was gathered for each segment within the study corridor from the Freight Analysis Framework and, using the mileage of each segment, converted to a daily truck VMT of 119,020 for the total length of the study corridor (this raw data is shown in Table C-3 of Appendix C). This value was multiplied by 365 to get annual truck VMT. These values are presented in Table 14.

Table 14. Measures required for Safety Calculations for U.S. 460 Study Corridor

\begin{tabular}{|l|l|}
\hline \multicolumn{1}{|c|}{ Measures } & U.S. 460 Study Corridor \\
\hline Distance & 50 miles \\
\hline Freight Analysis Framework AADTT 2007 & 2377 (weighted average) \\
\hline Daily Truck VMT & 119020 \\
\hline Total Annual Truck VMT (x100 million) & 0.434423 \\
\hline
\end{tabular}


Truck crash rates for the U.S. 460 corridor were derived simply by dividing values presented in Table 13 by the value for total annual truck VMT presented in Table 14. The calculated truck crash rates for the years 2005-2010 by crash type for the U.S. 460 study corridor are presented in Table 15.

Table 15. 2005-2010 Truck Crash Rates by Crash Type on U.S. 460 Study Corridor

\begin{tabular}{|l|c|c|c|c|c|c|c|}
\hline $\begin{array}{c}\text { Truck Crash Rate } \\
\text { per 100 million } \\
\text { Truck VMT }\end{array}$ & \multicolumn{6}{|c|}{ Truck Crash Rates on U.S. 460 Study Corridor } \\
\cline { 2 - 9 } & 2005 & 2006 & 2007 & 2008 & 2009 & 2010 & $\begin{array}{c}2005-2010 \\
\text { Average }\end{array}$ \\
\hline Fatal Crash Rate & 2.3 & 9.2 & 9.2 & 9.2 & 0.0 & 6.9 & 6.1 \\
\hline Persons Killed Rate & 6.9 & 9.2 & 9.2 & 9.2 & 0.0 & 6.9 & 6.9 \\
\hline Injury Crash Rate & 29.9 & 34.5 & 27.6 & 23.0 & 29.9 & 13.8 & 26.5 \\
\hline Persons Injured Rate & 36.8 & 50.6 & 46.0 & 25.3 & 34.5 & 18.4 & 35.3 \\
\hline PDO Crash Rate & 43.7 & 76.0 & 50.6 & 23.0 & 73.7 & 25.3 & 48.7 \\
\hline Total Crash Rate & 76.0 & 119.7 & 87.5 & 55.2 & 103.6 & 46.0 & 81.3 \\
\hline $\begin{array}{l}\text { Crash Severity Rate } \\
\text { (12:3:1) }\end{array}$ & 161.1 & 290.0 & 244.0 & 202.6 & 163.4 & 149.6 & 201.8 \\
\hline
\end{tabular}

Compared with truck crash rates on other Virginia Primary Roadways that were presented in Table 9, only the average truck fatality crash and persons killed rates are higher on the U.S. 460 study corridor at a ratio of 6.1 to 2.9 and 6.9 to 3.4, respectively. Similarly, when compared with crash rates on the Virginia interstate highways in Table 9, which have similar characteristics as the proposed U.S. 460 expressway, only average truck fatality crash and person killed rates on the existing roadways are higher. These comparisons are presented in Table 16 below.

The difference between the current and interstate-grade proposed expressway are presented for fatality crash and persons killed rates, alongside the potential annual reduction in the number of fatal crashes and persons killed, given the existing truck VMT in the study corridor. Using a value of \$7.2 million given by the Federal Motor Carrier Safety Administration (FMCSA, 2008) as the cost of each medium/heavy vehicle fatality crash, it can be estimated by multiplying with the potential 2.2 crashes reduced that $\$ 15.8$ million in annual excess trucking costs (or $\$ 43,400$ per day) can be potentially eliminated with the construction of the proposed U.S. 460 expressway. 
Table 16. Comparison of Average Crash Rates for U.S. 460 Study Corridor to All Virginia Primary and Interstate Roadways

\begin{tabular}{|l|c|c|c||c||c|}
\hline Average Annual Virginia Truck Crash Rates per 100 million Truck VMT & \\
\hline $\begin{array}{l}\text { Truck Crash Rate } \\
\text { Type }\end{array}$ & $\begin{array}{c}\text { U.S. 460 } \\
\text { Study } \\
\text { Corridor } \\
2005-2010\end{array}$ & $\begin{array}{c}\text { Interstate } \\
\text { System } \\
2005-2007\end{array}$ & $\begin{array}{c}\text { Primary } \\
\text { Roadways } \\
2005-2007\end{array}$ & $\begin{array}{c}\text { U.S. 460 to } \\
\text { Interstate } \\
\text { System } \\
\text { Difference }\end{array}$ & $\begin{array}{c}\text { Potential } \\
\text { Annual } \\
\text { Crash } \\
\text { Reduction }\end{array}$ \\
\hline Fatal Crash Rate & 6.1 & 1.0 & 2.9 & 5.2 & 2.2 \\
\hline Persons Killed Rate & 6.9 & 1.1 & 3.4 & 5.8 & 2.5 \\
\hline Injury Crash Rate & 26.5 & 30.0 & 51.6 & - & - \\
\hline Persons Injured Rate & 35.3 & 44.4 & 74.0 & - & - \\
\hline PDO Crash Rate & 48.7 & 60.3 & 92.6 & - & - \\
\hline Total Crash Rate & 81.3 & 91.2 & 147.2 & - & - \\
\hline $\begin{array}{l}\text { Crash Severity Rate } \\
\text { (12:3:1) }\end{array}$ & 201.8 & 161.8 & 261.7 & 40.0 & n/a \\
\hline
\end{tabular}

Several notes must be made regarding the presented crash rates. First, many confounding factors influence crash rates and simply improving or upgrading a roadway is no guarantee that potential crash reduction numbers will be realized. Higher truck volumes, or even higher volumes of other vehicles, on the new roadway could reduce the projected safety benefits, for example. Additionally, because the proposed U.S. 460 expressway would include a new interchange at either end, it is worth noting that interchanges often include higher incident rates due to factors like merges, curves, and slowing traffic; thus, while the roadway itself may see reduced crash numbers, the new interchanges may experience a higher number of crashes than before. Finally, a major assumption has been made regarding truck volumes in that trucks in particular would shift from the old highway onto the new tolled expressway, thus transferring truck crashes to the new expressway from the existing alignment.

\subsubsection{Calculating U.S. 460 Economic Hindrance}

The calculated values of excess trucking costs can now be used in the derived inoperability input-output model to determine a value of economic hindrance caused to other industries due to excess trucking costs incurred by the trucking sector. Note that this value clearly should not be used in conjunction with the first economic metric calculated, as it would be double counting.

The calculated consequences of the economic hindrance incurred by an excess trucking cost based on travel time savings of $\$ 52,000$ per day and truck fatality crash savings of $\$ 43,400$ per day to the trucking sector are shown in Table 17 below. This value is calculated by simply multiplying the individual excess trucking costs calculated above with the BEA dollar loss ratio calculated previously in the inoperability inputoutput model and presented again in Table 17. Note that for the trucking sector, the model shows a loss of $114 \%$, however in order to not double count, only a value of $14 \%$ is shown, because the remaining $100 \%$ is already tabulated as the excess trucking cost above. 
Table 17. Economic hindrance by industry based on calculated excess trucking costs to the trucking sector on U.S 460

\begin{tabular}{|c|c|c|c|}
\hline \multirow[b]{2}{*}{ BEA Industry Labels (Input-Output Model) } & \multirow[b]{2}{*}{$\begin{array}{c}\text { BEA } \$ \\
\text { loss, } \\
\text { ratio }\end{array}$} & \multicolumn{2}{|c|}{$\begin{array}{c}\text { Daily Economic } \\
\text { Hindrance, } \$\end{array}$} \\
\hline & & $\begin{array}{c}\text { Mobility } \\
\text { (travel time) }\end{array}$ & $\begin{array}{c}\text { Safety } \\
\text { (truck } \\
\text { crashes) }\end{array}$ \\
\hline Truck transportation & 1.1428 & 7423 & 6195 \\
\hline Petroleum and coal products & 0.1169 & 6080 & 5075 \\
\hline Oil and gas extraction & 0.0952 & 4951 & 4132 \\
\hline Wholesale trade & 0.0661 & 3436 & 2867 \\
\hline Motor vehicles, bodies and trailers, and parts & 0.0364 & 1892 & 1579 \\
\hline Warehousing and storage & 0.0240 & 1249 & 1042 \\
\hline Chemical products & 0.0237 & 1232 & 1029 \\
\hline Fabricated metal products & 0.0184 & 959 & 800 \\
\hline Retail trade & 0.0177 & 919 & 767 \\
\hline Plastics and rubber products & 0.0172 & 892 & 745 \\
\hline Primary metals & 0.0154 & 802 & 670 \\
\hline Utilities & 0.0100 & 520 & 434 \\
\hline Computer systems design and related services & 0.0090 & 466 & 389 \\
\hline Information and data processing services & 0.0089 & 462 & 385 \\
\hline Machinery & 0.0070 & 364 & 303 \\
\hline Computer and electronic products & 0.0066 & 346 & 288 \\
\hline Electrical equipment, appliances, and components & 0.0064 & 335 & 280 \\
\hline Paper products & 0.0063 & 328 & 274 \\
\hline Waste management and remediation services & 0.0058 & 300 & 251 \\
\hline Publishing industries (includes software) & 0.0055 & 286 & 238 \\
\hline Construction & 0.0052 & 272 & 227 \\
\hline Printing and related support activities & 0.0040 & 208 & 174 \\
\hline Food services and drinking places & 0.0036 & 189 & 158 \\
\hline Nonmetallic mineral products & 0.0028 & 144 & 120 \\
\hline Support activities for mining & 0.0026 & 133 & 111 \\
\hline Mining, except oil and gas & 0.0025 & 127 & 106 \\
\hline Food and beverage and tobacco products & 0.0023 & 121 & 101 \\
\hline Wood products & 0.0021 & 111 & 92 \\
\hline Miscellaneous manufacturing & 0.0016 & 82 & 68 \\
\hline Farms & 0.0015 & 80 & 67 \\
\hline Textile mills and textile product mills & 0.0015 & 78 & 65 \\
\hline Forestry, fishing, and related activities & 0.0012 & 61 & 51 \\
\hline Other transportation equipment & 0.0011 & 59 & 49 \\
\hline Furniture and related products & 0.0005 & 25 & 21 \\
\hline Apparel and leather and allied products & 0.0005 & 24 & 20 \\
\hline Other (services, government, etc.) & varies & 20,168 & 16,831 \\
\hline \multicolumn{2}{|c|}{ Daily Total } & 55,125 & 46,005 \\
\hline \multicolumn{2}{|c|}{ Daily Total per Mile } & 1103 & 920 \\
\hline \multicolumn{2}{|c|}{ Annual Total } & $20,120,618$ & $16,791,749$ \\
\hline
\end{tabular}


Thus, it is shown that current mobility constraints on U.S. 460 cause additional economic hindrances of approximately $\$ 55,000$ per day, totaling over $\$ 20$ million annually to industry, which has the potential to be reduced or eliminated with the construction of the U.S. 460 expressway, depending on the amount of the toll that is charged. Additionally, about $\$ 46,000$ per day, or $\$ 16.8$ million per year, in excess trucking costs due to truck fatality crashes in the U.S. 460 study corridor might be reduced if the interstate-grade U.S. 460 expressway were constructed.

\subsubsection{Summary of U.S. 460 Findings}

A summary of the values for U.S. 460 expressway concept demonstration presented in the tables above is given below in Table 18, many of which are presented later in the 7.5 Decision Model section.

Table 18. Summary Table of U.S. 460 Measures

\begin{tabular}{|c|c|c|c|}
\hline \multirow{2}{*}{$\begin{array}{l}\text { Corridor } \\
\text { Metrics }\end{array}$} & \multicolumn{2}{|c|}{ Length of Corridor } & 50 miles \\
\hline & \multicolumn{2}{|l|}{ AADTT } & 2377 daily trucks \\
\hline \multirow{4}{*}{$\begin{array}{l}\text { Travel Time } \\
\text { Savings }\end{array}$} & \multicolumn{2}{|c|}{ Entire Corridor Length per Truck } & 13 minutes per truck \\
\hline & \multicolumn{2}{|c|}{ Rate Per Truck } & 0.26 minutes per truck per mile \\
\hline & \multicolumn{2}{|c|}{ Annual Savings, Entire Corridor } & 30,900 minutes \\
\hline & \multicolumn{2}{|c|}{ Annual Savings, Rate Per Mile } & 618 minutes per mile \\
\hline \multirow{3}{*}{$\begin{array}{l}\text { Truck Crash } \\
\text { Severity } \\
2005-2010 \\
\text { (Fatal:Injury: } \\
\text { Property } \\
\text { Damage Only } \\
\text { ratio of 12:3:1) }\end{array}$} & \multicolumn{2}{|c|}{ Rate per 100 million VMT } & $\begin{array}{c}201.8 \text { crashes per } 100 \text { million } \\
\text { VMT }\end{array}$ \\
\hline & \multicolumn{2}{|c|}{ Rate Difference with Improvement } & $\begin{array}{c}40 \text { less crashes per } 100 \text { million } \\
\text { VMT }\end{array}$ \\
\hline & \multicolumn{2}{|c|}{$\begin{array}{l}\text { Annual Reduction per Mile } \\
\text { (Rate*VMT / 50) }\end{array}$} & 0.35 less crashes per mile \\
\hline \multirow{7}{*}{$\begin{array}{l}\text { Proposed } \\
\text { Economic } \\
\text { Metrics }\end{array}$} & \multicolumn{2}{|c|}{ Economic Importance } & 3.56 \\
\hline & \multirow{4}{*}{$\begin{array}{l}\text { Excess } \\
\text { Trucking } \\
\text { Cost, } \$\end{array}$} & Mobility - daily & $\$ 52,000$ per day \\
\hline & & Mobility - daily per mile & $\$ 1040$ per day per mile \\
\hline & & Safety - daily & $\$ 43,400$ per day \\
\hline & & Safety - daily per mile & $\$ 868$ per day per mile \\
\hline & \multirow{2}{*}{\begin{tabular}{|l} 
Economic \\
Hindrance, \$
\end{tabular}} & Mobility - daily per mile & $\$ 1103$ per day per mile \\
\hline & & Safety - daily per mile & $\$ 920$ per day per mile \\
\hline
\end{tabular}

\subsection{Concept Demonstration \#2: U.S. 29 Bypass - Charlottesville / Albemarle County, VA}

The U.S. 29 corridor serves central Virginia and north-central North Carolina from the Washington, DC metropolitan area south to Greensboro, North Carolina via Gainesville, Warrenton, Culpeper, Charlottesville, Lynchburg, and Danville, Virginia. Between I-66 in Northern Virginia and Greensboro, North Carolina, the U.S. 29 corridor is, at a minimum, a four-lane divided highway with numerous at-grade crossings, many of which are signalized. For longer distance trips, truckers might conceivably select roughly parallel Interstate 81 and U.S. 220 or Interstate 85 and Interstate 95 for a higher level of 
service route, as depicted in Figure 7. However, approximately $67 \%$ of tonnage on the U.S. 29 corridor in Virginia is pass-through freight (Cambridge Systematics, 2010).

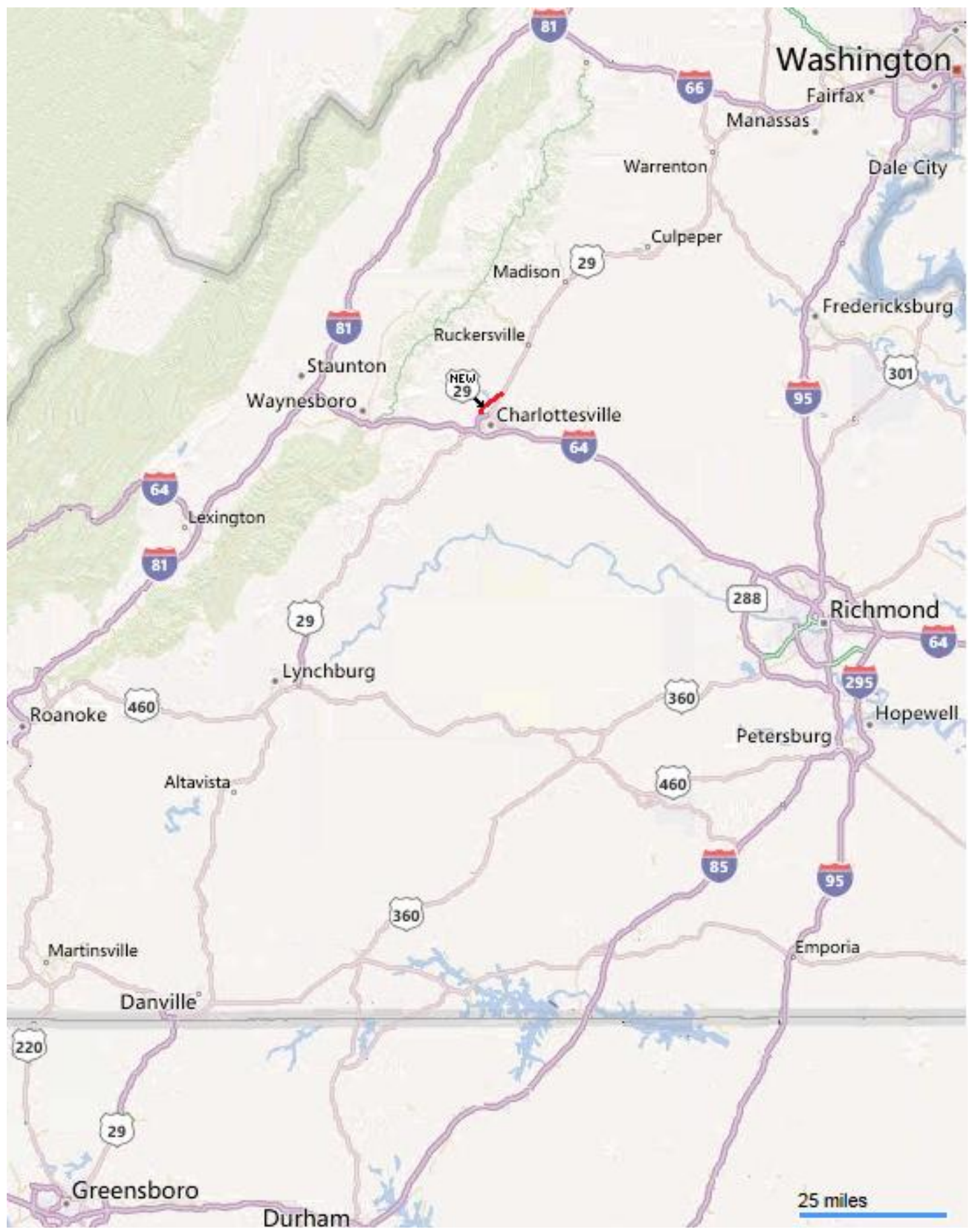

Figure 7. Map of U.S. 29 corridor with proposed bypass and other major alternate routes

Regionally, in central Virginia, there is much debate on whether stoplights on the U.S. 29 corridor, specifically a segment with a reduced speed of 45 mile per hour and a sequence of 13 traffic lights just north of Charlottesville impede mobility such that they serve as a bottleneck to reduce economic activity in Lynchburg and Danville with the 
Northeast Corridor, i.e., Washington, DC; New York City; etc., and thus hinder economic growth in that area of southern Virginia. As a result, a 6.2-mile bypass is proposed for construction north of Charlottesville in Albemarle County as an alternate route to avoid this heavily commercially developed area (VDOT, 2012-d).

\subsubsection{Calculating U.S. 29 Economic Importance}

Estimates of freight tonnage carried on the U.S. 29 corridor was performed slightly differently than for the U.S. 460 corridor, in part to demonstrate alternate methods, but also because of the difference in alignment of the corridors. First, as above, Freight Analysis Framework region groupings were developed, given the directionality of U.S. 29 and natural flow for traffic from northeast to the south and west, as well as the positioning of other parallel routes. Unlike the U.S. 460 concept demonstration in which routes are less parallel and branch out in different directions, the U.S. 29 corridor has a number of parallel corridors that serve similar Freight Analysis Framework region origins and destinations (e.g., I-81, I-95, and connecting routes such as U.S. 220 and I-85, respectively), as shown in Figure 7 . Thus, route assignment based on origin-destination regions, even those that are the size of the Freight Analysis Framework regions, are much more difficult for this corridor.

Commodity flows through the region were determined using Freight Analysis Framework data. Origins and destinations of commodity flows were sorted into several main groups: the Northeast, where traffic travels through or around DC for points to or from the south and west; Virginia, which includes the Remainder of Virginia Freight Analysis Framework region around Charlottesville; a South region; and a West region that is conceivably connected to the U.S. 29 corridor via I-64 at Charlottesville. A final group, the Northwest region, was discarded from analysis, since the U.S. 29 corridor seems to be an unlikely route given its directionality. These groupings are shown in Figure 8 with the Interstate Highway System to show connections from the U.S. 29 corridor to these regions.

Using a screenline across central Virginia, 2007 AADTT volumes were taken from the Freight Analysis Framework for I-81, the U.S. 29 bypass segment, and I-95. These AADTT volumes were used to assign tonnage values for each corridor.

Specifically, approximately 1744 trucks per day travel on the U.S. 29 corridor segment of the proposed bypass, while AADTT for I-95 and I-81 are 15,000 and 12,000 trucks, respectively, as shown in Table 19 . Thus, approximately $6 \%$ of the total tonnage of selected commodities was assigned to the U.S. 29 corridor. The values generated from the inoperability input-output model are applied to this commodity tonnage to provide a value of economic importance, which is also shown in Table 19, in bold text; the value of economic importance for the U.S. 29 corridor is 16.43. In this concept demonstration, because the regional origin-destination groups are the same for all three corridors, the value of economic importance will be exactly proportional to the AADTT volumes for the three corridors. 


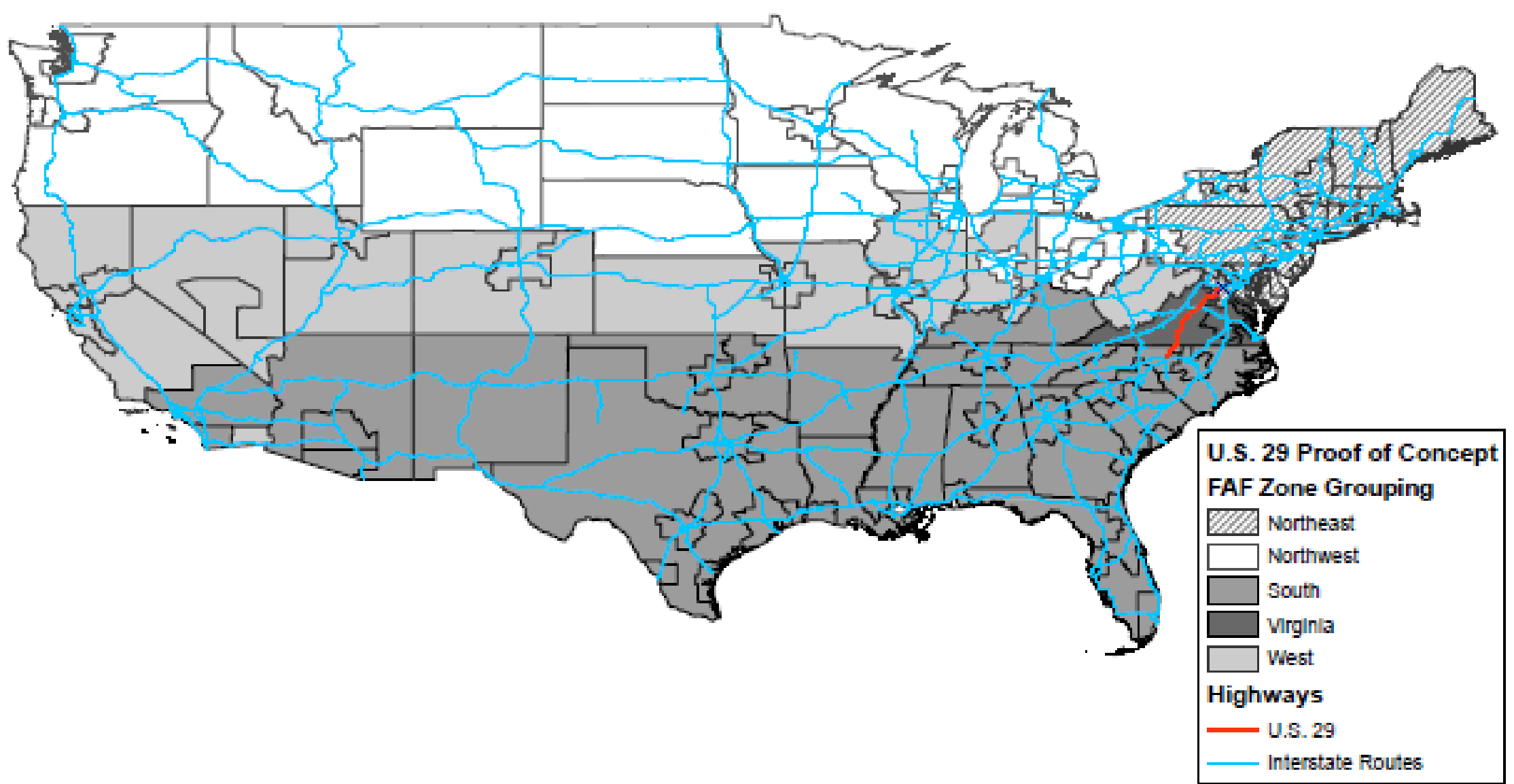

Figure 8. Freight Analysis Framework region groupings for origin-destination route assignment designation through central Virginia 
Table 19. Total Commodity Tonnage by Route for U.S. 29 Concept Demonstration

\begin{tabular}{|c|c|c|c|c|c|c|c|}
\hline \multirow[b]{2}{*}{ Commodity } & \multicolumn{4}{|c|}{$\begin{array}{c}\text { Kilotons by route for Concept } \\
\text { Demonstration }\end{array}$} & \multicolumn{3}{|c|}{$\begin{array}{l}\text { Input-Output Economic } \\
\text { Importance by route for } \\
\text { Concept Demonstration }\end{array}$} \\
\hline & Total & US 29 & $\mathrm{I}-95$ & $\mathrm{I}-81$ & US 29 & I-95 & $\mathrm{I}-81$ \\
\hline Cereal Grains & 18334 & 1112 & 9567 & 7654 & 2.15 & 18.48 & 14.78 \\
\hline Meat/Seafood & 7947 & 482 & 4147 & 3318 & 0.93 & 8.01 & 6.41 \\
\hline Milled grain prods. & 5421 & 329 & 2829 & 2263 & 0.64 & 5.46 & 4.37 \\
\hline Other foodstuffs & 25754 & 1563 & 13440 & 10752 & 3.02 & 25.96 & 20.76 \\
\hline Building Stone & 714 & 43 & 373 & 298 & 0.11 & 0.94 & 0.75 \\
\hline Gravel & 30442 & 1847 & 15886 & 12709 & 4.63 & 39.85 & 31.88 \\
\hline Natural sands & 1937 & 118 & 1011 & 809 & 0.29 & 2.54 & 2.03 \\
\hline Nonmetallic minerals & 10524 & 639 & 5492 & 4394 & 1.60 & 13.78 & 11.02 \\
\hline Logs & 14873 & 902 & 7761 & 6209 & 1.49 & 12.84 & 10.27 \\
\hline Wood Prods. & 19758 & 1199 & 10311 & 8248 & 1.57 & 13.46 & 10.77 \\
\hline Total & 135703 & 8234 & 70817 & 56653 & 16.43 & 141.30 & 113.04 \\
\hline AADTT & 28744 & 1744 & 15000 & 12000 & & & \\
\hline Percentage of total & 100 & 6 & 52 & 42 & & & \\
\hline
\end{tabular}

It is possible that a new, improved U.S. 29 bypass will alleviate a bottleneck in the regions such that it would not only serve existing U.S. 29 truck traffic on the existing route, but also attract truck traffic from other, more congested neighboring routes like I81, for example (NCHRP 365 presents a traffic shift methodology for corridors that might be used to estimate the amount of diversion [Martin and McGuckin, 1998]).

Additionally, the cities of Lynchburg and Danville could benefit from new industry with this improved connection to markets in the north. All of these possibilities would increase truck volumes on U.S. 29, and thus potentially provide added significance to the corridor and benefit to the trucking industry as a whole. However, for the purposes of this concept demonstration, only existing truck volumes were analyzed.

\subsubsection{Calculating U.S. 29 Excess Trucking Costs}

Excess trucking costs calculated for mobility and safety are calculated for this concept demonstration based on travel time savings and potential truck crash reduction for a scenario comparing the existing U.S. 29 with the projected benefits of a completed U.S. 29 bypass.

A conservative estimate of total excess trucking costs can be derived using 2007 AADTT and truck speed values from the Freight Analysis Framework. The hourly value of commercial vehicle time used to calculate excess costs is $\$ 105.67$ as reported in TTI's Urban Mobility Report (Schrank et al., 2010). Given 2007 truck speeds on the existing U.S. 29 corridor is 47.3 miles per hour, and will be compared to an estimated truck speed for the new bypass of 55 miles per hour, the expected posted speed limit. It should be noted that the former value is likely high considering the speed limit of the existing U.S. 29 is only 45 miles per hour, and there is great likelihood of truck traffic being further 
hindered by traffic lights; however, this value, as given by the Freight Analysis Framework is used for consistency, and provides a conservative estimate. The difference in current and new truck speeds result in a travel time savings of 0.7 minutes per truck. With a 2007 AADTT of 1744 trucks per day, this results in 20 hours of delay and excess trucking costs per day of $\$ 2150$, or $\$ 785,000$ per year.

Excess trucking costs can similarly be calculated from other measures, such as projected safety benefits. Crash data on a CD for the entire state of Virginia for 20052010 were obtained directly from the VDOT Central Office, by request. Crash data on this $\mathrm{CD}$ were organized in a series of tables. In order to glean relevant truck crash data specifically for the U.S. 29 study corridor, two tables (i.e., "crash document" and "crash vehicle") had to be joined by the crash document number. Several filters were applied to this data. Data were limited to crashes that:

- Include vehicle classes that identify trucks;

- Occurred on U.S. 29; and

- Occurred between Latitude/Longitude points of either end of the U.S. 29 study area $(38.057148,-78.495598$ and 38.112477,-78.453026), or

- Occurred between state designated U.S. 29 mileposts of the study area (139.404 to 143.417).

Note that both latitude/longitude coordinates and mileposts were used to locate relevant crash data since neither of these fields was consistently completed for all crash data for all years. This raw crash data for the U.S. 29 study corridor is presented in Table C-2 of Appendix C. The filtered crash data relevant to the U.S. 29 study corridor for years 2005-2010 is presented in Table 20.

Table 20. 2005-2010 Truck Crashes by Crash Type on U.S. 29 Study Corridor

\begin{tabular}{|l|c|c|c|c|c|c|c|}
\hline & \multicolumn{6}{|c|}{ Truck Crashes on U.S. 29 Study Corridor } \\
\cline { 2 - 9 } \multicolumn{1}{c}{ Crash Type } & 2005 & 2006 & 2007 & 2008 & 2009 & 2010 & $\begin{array}{c}\text { 2005-2010 } \\
\text { Average }\end{array}$ \\
\hline Fatal Crash & 0 & 0 & 0 & 0 & 0 & 0 & 0.0 \\
\hline Persons Killed & 0 & 0 & 0 & 0 & 0 & 0 & 0.0 \\
\hline Injury Crash & 8 & 5 & 1 & 3 & 3 & 3 & 3.8 \\
\hline Persons Injured & 14 & 5 & 2 & 4 & 5 & 5 & 5.8 \\
\hline PDO Crash & 11 & 9 & 11 & 16 & 12 & 22 & 13.5 \\
\hline Total Crash & 19 & 14 & 12 & 19 & 15 & 25 & 17.3 \\
\hline $\begin{array}{l}\text { Crash Severity } \\
\text { Number (12:3:1) }\end{array}$ & 35 & 24 & 14 & 25 & 21 & 31 & 25.0 \\
\hline
\end{tabular}

To normalize the data, the distance of the existing segment to be replaced was determined to be 4 miles based on the farthest endpoints of crash data. The 2007 AADTT of the existing segment was gathered for the study corridor segment from the Freight Analysis Framework and converted to a daily truck VMT of 6976 for the total length of the study corridor. This value was multiplied by 365 to get annual truck VMT. These values are presented in Table 21. 
Table 21. Measures used for Safety Calculations for U.S. 29 Study Corridor

\begin{tabular}{|l|r|}
\hline \multicolumn{1}{|c|}{ Measures } & U.S. 29 Study Corridor \\
\hline Distance & 4 miles \\
\hline Freight Analysis Framework AADTT 2007 & 1744 vehicles \\
\hline Daily Truck VMT & 6976 \\
\hline Total Annual Truck VMT (x100 million) & 0.025462 \\
\hline
\end{tabular}

Truck crash rates for the U.S. 29 corridor were derived simply by dividing values presented in Table 20 by the value for total annual truck VMT presented in Table 21. The calculated truck crash rates for the years 2005-2010 by crash type for the U.S. 460 study corridor are presented in Table 22.

Table 22. 2005-2010 Truck Crash Rates by Crash Type on U.S. 29 Study Corridor

\begin{tabular}{|l|c|c|c|c|c|c|c|}
\hline \multirow{2}{*}{$\begin{array}{l}\text { Crash rates per 100 } \\
\text { million Truck VMT }\end{array}$} & \multicolumn{6}{|c|}{ Truck Crash Rates on U.S. 29 Study Corridor } \\
\cline { 2 - 9 } & 2005 & 2006 & 2007 & 2008 & 2009 & 2010 & $\begin{array}{c}2005-2010 \\
\text { Average }\end{array}$ \\
\hline Fatal Crash Rate & 0 & 0 & 0 & 0 & 0 & 0 & 0 \\
\hline Persons Killed Rate & 0 & 0 & 0 & 0 & 0 & 0 & 0 \\
\hline Injury Crash Rate & 314.2 & 196.4 & 39.3 & 117.8 & 117.8 & 117.8 & 150.5 \\
\hline Persons Injured Rate & 549.8 & 196.4 & 78.5 & 157.1 & 196.4 & 196.4 & 229.1 \\
\hline PDO Crash Rate & 432.0 & 353.5 & 432.0 & 628.4 & 471.3 & 864.0 & 530.2 \\
\hline Total Crash Rate & 746.2 & 549.8 & 471.3 & 746.2 & 589.1 & 981.8 & 680.7 \\
\hline $\begin{array}{l}\text { Crash Severity Rate } \\
(12: 3: 1)\end{array}$ & 1374.6 & 942.6 & 549.8 & 981.8 & 824.7 & 1217.5 & 981.8 \\
\hline
\end{tabular}

Compared with truck crash rates on other Virginia Primary Roadways that were presented in Table 9, only the average truck fatality crash and persons killed rates are lower on the U.S. 29 study corridor, with zero fatal crashes recorded for the six years presented. Similarly, when compared with crash rates on the Virginia interstate highways in Table 9, which have similar characteristics as the proposed U.S. 29 bypass, only average truck fatality crash and person killed rates on the existing roadway is lower. In fact, perhaps due to the more urban nature of the U.S. 29 corridor with slower speeds and frequent traffic signals, the truck crash rate is notably higher than the state average for other primary roadways. These comparisons are presented in Table 23 below. 
Table 23. Comparison of Average Crash Rates for U.S. 29 Study Corridor to All Virginia Primary and Interstate Roadways

\begin{tabular}{|l|c|c|c||c||c|}
\hline \multicolumn{1}{|c|}{ Average Annual Virginia Truck Crash Rates per 100 million Truck VMT } & \\
\hline $\begin{array}{c}\text { Truck Crash Rate } \\
\text { Type }\end{array}$ & $\begin{array}{c}\text { U.S. 29 } \\
\text { Study } \\
\text { Corridor } \\
2005-2010\end{array}$ & $\begin{array}{c}\text { Interstate } \\
\text { System } \\
2005-2007\end{array}$ & $\begin{array}{c}\text { Primary } \\
\text { Roadways } \\
2005-2007\end{array}$ & $\begin{array}{c}\text { Interstate } \\
\text { System } \\
\text { Difference }\end{array}$ & $\begin{array}{c}\text { Potential } \\
\text { Annual } \\
\text { Crash } \\
\text { Reduction }\end{array}$ \\
\hline Fatal Crash Rate & 0.0 & 1.0 & 2.9 & - & - \\
\hline Persons Killed Rate & 0.0 & 1.1 & 3.4 & - & - \\
\hline Injury Crash Rate & 150.5 & 30.0 & 51.6 & 120.6 & 3.1 \\
\hline $\begin{array}{l}\text { Persons Injured } \\
\text { Rate }\end{array}$ & 229.1 & 44.4 & 74.0 & 184.7 & 4.7 \\
\hline PDO Crash Rate & 530.2 & 60.3 & 92.6 & 469.9 & 12.0 \\
\hline Total Crash Rate & 680.7 & 91.2 & 147.2 & 589.5 & 15.0 \\
\hline $\begin{array}{l}\text { Crash Severity Rate } \\
(12: 3: 1)\end{array}$ & 981.8 & 161.8 & 261.7 & 820.1 & n/a \\
\hline
\end{tabular}

The difference between the current and interstate-grade proposed expressway are presented for injury, PDO, and total crash rates and persons injured, alongside the potential annual reduction in the number of these crashes and persons injured, given the existing truck VMT in the study corridor. Using a value of $\$ 331,108$ given by the Federal Motor Carrier Safety Administration (FMCSA, 2008) as the average cost of each injury crash involving a medium/heavy vehicle, it can be estimated by multiplying with the potential 3.1 crashes reduced that over $\$ 1$ million in annual excess trucking costs (or $\$ 2800$ per day) can be potentially eliminated with the construction of the proposed U.S. 29 bypass. Likewise, FMCSA (2008) gives a value of $\$ 148,279$ as the average cost for a truck-involved crash for all medium/heavy vehicles. From this, it can be estimated by multiplying with the potential 12 crashes reduced that about $\$ 1.8$ million in annual excess trucking costs (or $\$ 4900$ per day) can be potentially eliminated with the construction of the proposed U.S. 29 bypass.

\subsubsection{Calculating U.S. 29 Economic Hindrance}

The calculated values of excess trucking costs can be used in the derived inoperability input-output model to determine a value of economic hindrance caused to other industries due to excess trucking costs incurred by the trucking sector. Note, this value clearly should not be used in conjunction with the first value calculated, as it would be double counting.

The calculated consequences of the economic hindrance incurred by an excess trucking cost based on travel time savings of $\$ 2150$ per day and truck fatality crash savings of $\$ 7700$ per day to the trucking sector are shown in Table 24 below. This value is calculated by simply multiplying the individual excess trucking costs calculated above with the BEA dollar loss ratio calculated previously and presented again in Table 24. Note that for the trucking sector, the model shows a loss of $114 \%$, however in order to 
not double count, only a value of $14 \%$ is shown, since the remaining $100 \%$ is already tabulated above as a part of the excess trucking cost.

Thus, it is shown that current mobility constraints on U.S. 29 cause additional economic hindrances of nearly $\$ 2300$ per day, totaling over $\$ 830,000$ annually to industry, which has the potential to be reduced or eliminated with the construction of the U.S. 29 bypass. Additionally, over $\$ 8100$ per day, or almost $\$ 3$ million per year, in excess trucking costs due to truck crashes in the U.S. 29 study corridor might be reduced if the interstate-grade U.S. 29 bypass were constructed.

Several notes must be made regarding the presented crash rates. First, many factors influence crash rates and simply improving or upgrading a roadway is no guarantee that potential crash reduction numbers will be realized. Higher truck volumes, or even higher volumes of other vehicles, on the new roadway could reduce the projected safety benefits, for example. Additionally, because the proposed U.S. 29 bypass would include a new interchange at either end, including one involving a stop light with a left turn for through traffic, it is worth noting that interchanges often include higher incident rates due factors like merges, curves, and slowing traffic; thus, while the roadway itself may see reduced crash numbers, the new interchanges may experience a higher number of crashes than the old alignment. At the same time, other programmed projects, such as that which involves adding a second lane to the southbound U.S. 29 on-ramp at the junction with U.S. 250, could potentially achieve similar safety benefits, which would necessarily be included in the final decision model for comprehensive comparison of potential derived benefits. Finally, because the existing U.S. 29 corridor has numerous businesses, many trucks will likely still travel on the existing roadway, thus reducing the full projected benefits for potential reduction of truck crashes of the proposed U.S. 29 bypass. 
Table 24. Economic hindrance by industry based on calculated mobility-based excess trucking costs to the trucking sector on U.S. 29

\begin{tabular}{|c|c|c|c|}
\hline \multirow[b]{2}{*}{ BEA Industry Labels (Input-Output Model) } & \multirow[b]{2}{*}{$\begin{array}{c}\text { BEA } \$ \\
\text { loss, } \\
\text { ratio }\end{array}$} & \multicolumn{2}{|c|}{$\begin{array}{c}\text { Daily Economic } \\
\text { Hindrance, } \$\end{array}$} \\
\hline & & $\begin{array}{c}\text { Mobility } \\
\text { (travel time) }\end{array}$ & $\begin{array}{c}\text { Safety } \\
\text { (truck } \\
\text { crashes) }\end{array}$ \\
\hline Truck transportation & 1.1428 & 307 & 1097 \\
\hline Petroleum and coal products & 0.1169 & 251 & 899 \\
\hline Oil and gas extraction & 0.0952 & 205 & 732 \\
\hline Wholesale trade & 0.0661 & 142 & 508 \\
\hline Motor vehicles, bodies and trailers, and parts & 0.0364 & 78 & 280 \\
\hline Warehousing and storage & 0.0240 & 52 & 185 \\
\hline Chemical products & 0.0237 & 51 & 182 \\
\hline Fabricated metal products & 0.0184 & 40 & 142 \\
\hline Retail trade & 0.0177 & 38 & 136 \\
\hline Plastics and rubber products & 0.0172 & 37 & 132 \\
\hline Primary metals & 0.0154 & 33 & 119 \\
\hline Utilities & 0.0100 & 21 & 77 \\
\hline Computer systems design and related services & 0.0090 & 19 & 69 \\
\hline Information and data processing services & 0.0089 & 19 & 68 \\
\hline Machinery & 0.0070 & 15 & 54 \\
\hline Computer and electronic products & 0.0066 & 14 & 51 \\
\hline Electrical equipment, appliances, and components & 0.0064 & 14 & 50 \\
\hline Paper products & 0.0063 & 14 & 49 \\
\hline Waste management and remediation services & 0.0058 & 12 & 44 \\
\hline Publishing industries (includes software) & 0.0055 & 12 & 42 \\
\hline Construction & 0.0052 & 11 & 40 \\
\hline Printing and related support activities & 0.0040 & 9 & 31 \\
\hline Food services and drinking places & 0.0036 & 8 & 28 \\
\hline Nonmetallic mineral products & 0.0028 & 6 & 21 \\
\hline Support activities for mining & 0.0026 & 6 & 20 \\
\hline Mining, except oil and gas & 0.0025 & 5 & 19 \\
\hline Food and beverage and tobacco products & 0.0023 & 5 & 18 \\
\hline Wood products & 0.0021 & 5 & 16 \\
\hline Miscellaneous manufacturing & 0.0016 & 3 & 12 \\
\hline Farms & 0.0015 & 3 & 12 \\
\hline Textile mills and textile product mills & 0.0015 & 3 & 12 \\
\hline Forestry, fishing, and related activities & 0.0012 & 3 & 9 \\
\hline Other transportation equipment & 0.0011 & 2 & 9 \\
\hline Furniture and related products & 0.0005 & 1 & 4 \\
\hline Apparel and leather and allied products & 0.0005 & 1 & 4 \\
\hline Other (services, government, etc.) & varies & 834 & 2981 \\
\hline \multicolumn{2}{|c|}{ Daily Total } & 2279 & 8149 \\
\hline \multicolumn{2}{|c|}{ Daily Total per Mile } & 570 & 2037 \\
\hline \multicolumn{2}{|c|}{ Annual Total } & 831,958 & $2,974,252$ \\
\hline
\end{tabular}




\subsubsection{Summary of U.S. 29 Findings}

A summary of the values for the U.S. 29 bypass concept demonstration presented in the tables above is given below in Table 25, many of which are also used in the 7.5 Decision Model section.

Table 25. Summary Table of U.S. 29 Measures

\begin{tabular}{|c|c|c|c|}
\hline \multirow{2}{*}{$\begin{array}{l}\text { Corridor } \\
\text { Metrics }\end{array}$} & \multicolumn{2}{|c|}{ Length of Corridor } & 4 miles \\
\hline & \multicolumn{2}{|l|}{ AADTT } & 1744 daily trucks \\
\hline \multirow{4}{*}{$\begin{array}{l}\text { Travel Time } \\
\text { Savings }\end{array}$} & \multicolumn{2}{|c|}{ Entire Corridor Length Per Truck } & 0.71 minutes per truck \\
\hline & \multicolumn{2}{|c|}{ Rate Per Truck } & 0.18 minutes per truck per mile \\
\hline & \multicolumn{2}{|c|}{ Annual Savings, Entire Corridor } & 1238 minutes \\
\hline & \multicolumn{2}{|c|}{ Annual Savings Rate Per Mile } & $310 \mathrm{minu}$ \\
\hline \multirow{3}{*}{$\begin{array}{l}\text { Truck Crash } \\
\text { Severity } \\
\text { 2005-2010 } \\
\text { (Fatal:Injury: } \\
\text { Property } \\
\text { Damage Only } \\
\text { ratio of 12:3:1) } \\
\end{array}$} & \multicolumn{2}{|c|}{ Rate per 100 million VMT } & $\begin{array}{c}981.8 \text { crashes per } 100 \text { million } \\
\text { VMT }\end{array}$ \\
\hline & \multicolumn{2}{|c|}{ Rate Difference with Improvement } & $\begin{array}{c}820 \text { less crashes per } 100 \\
\text { million VMT }\end{array}$ \\
\hline & \multicolumn{2}{|c|}{$\begin{array}{l}\text { Annual Reduction per Mile } \\
\text { (Rate*Truck VMT/4) }\end{array}$} & 5.23 crashes reduced per mile \\
\hline \multirow{7}{*}{$\begin{array}{l}\text { Proposed } \\
\text { Economic } \\
\text { Metrics }\end{array}$} & \multicolumn{2}{|c|}{ Economic Importance } & 16. \\
\hline & \multirow{4}{*}{$\begin{array}{l}\text { Excess } \\
\text { Trucking } \\
\text { Cost, } \$\end{array}$} & Mobility - & $\$ 2150$ per day \\
\hline & & Mobility - daily per 1 & $\$ 538$ per day per mile \\
\hline & & Safety - & $\$ 7700$ per day \\
\hline & & Safety-daily per mile & $\$ 1925$ per day per mile \\
\hline & \multirow{2}{*}{\begin{tabular}{|l|} 
Economic \\
Hindrance, $\$$
\end{tabular}} & Mobility - daily per mile & $\$ 570$ per day per mile \\
\hline & & Safety - daily per mile & $\$ 2037$ per day per mile \\
\hline
\end{tabular}

\subsection{Decision Model}

A summary of the key metrics calculated and derived for both the U.S. 460 expressway and U.S. 29 bypass concept demonstrations above are presented in Table 26. Despite having only two corridors to compare, several simple decision models could be employed to rank the corridors for their relative benefits and thus prioritize the improvements. These decision models could also be used to compare a larger number of corridors, if scores were proportionately given to each metric between a range of zero to five, for example.

For this comparison, the first decision model uses equal weightings for all metrics, the second emphasizes safety metrics at a scale of 2:1, and the final emphasizes mobility measures also using a scale of 2:1. The outcome of these decision models are presented in Table 27 below. To avoid double counting, the economic importance metric is not used in any of the decision models. 
Table 26. Comparison of Key Metrics for U.S. 460 and U.S. 29 Study Corridors

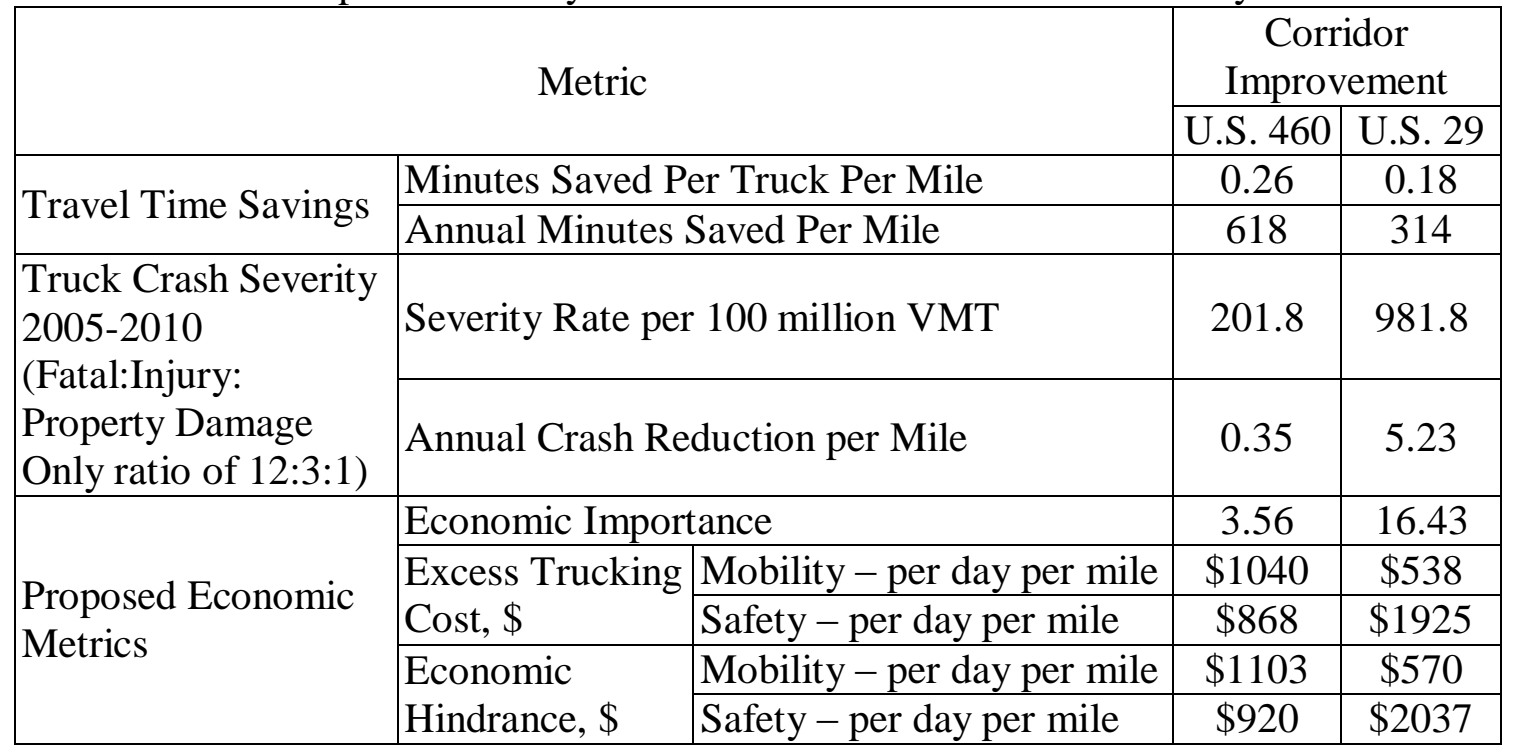

Table 27. Three decision model approaches to prioritize improvements

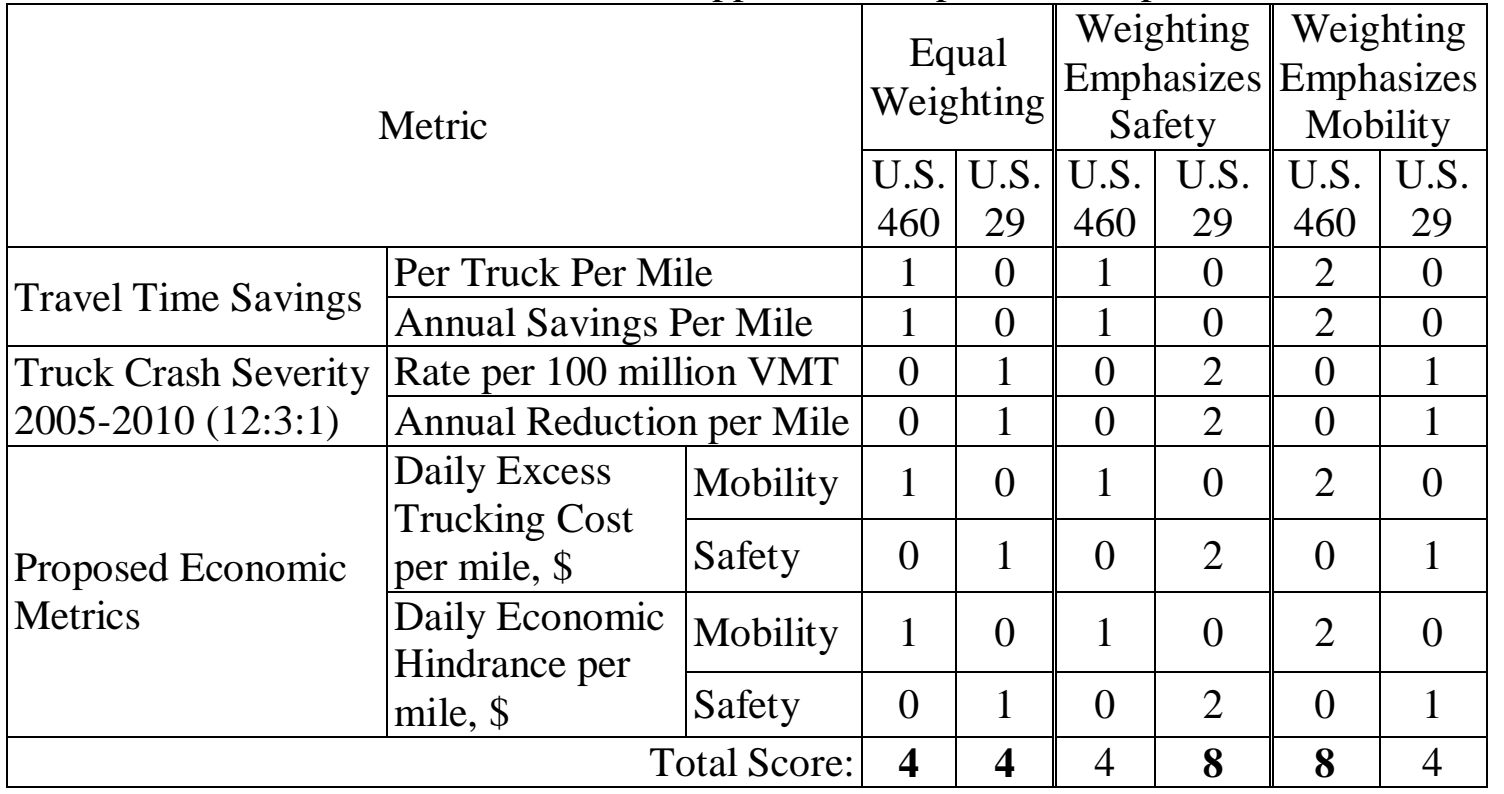

As Table 27 shows, of the two corridors being compared, the U.S. 460 corridor improvement provides greater mobility benefits while the U.S. 29 corridor improvement provides greater safety benefits. When all metrics employed here are taken equally, the two corridors have a tied score. However, this outcome is less likely given more corridor improvements to score proportionately for each metric on a scale of zero to five, for example, and an increased number of measures that would come from the Virginia Statewide Performance System to round out the freight module.

Alternatively, instead of presenting the proposed economic metrics as a ranking, because the units are normalized per mile and have a dollar value, the actual dollar value 
from these metrics could be summed and used for prioritizing the proposed improvements: the daily mobility and safety excess trucking costs per mile and economic hindrance per mile. This value could be used for a multitude of reasons, including in the event of a tie between several alternatives, as was the case with an equal weighting. In this case, the daily economic benefit derived per mile from improving the U.S. 460 and U.S. 29 corridors totals $\$ 3931$ and $\$ 5070$, respectively.

\subsection{Concept Demonstrations Discussion}

The results from these two concept demonstrations show the ability of the developed framework to take publicly available national data as well as other generally accessible state data to prioritize highway infrastructure improvements for freight. Using nationally available freight and economic data in conjunction with state mobility and safety data, a number of freight economic performance measures were developed to assess benefits associated with proposed improvements to the U.S. 460 and U.S. 29 corridors. Once these metrics have been developed, a number of methods are available to compare proposed improvements with one another, particularly if a focus on mobility or safety enhancement is preferred, for example.

The two concept demonstrations presented here illustrate the proposed prioritization framework using a robust, yet restricted dataset. Agencies would have the ability to incorporate additional or fewer commodities for economic analysis, as deemed appropriate given available resources to compile, process, and analyze data. Likewise, while truck travel time and truck crash severity data were incorporated for the concept demonstrations' analyses, depending upon the availability of this data from the state, or the desire to incorporate additional measures, e.g., environmental metrics, additional freight economic measures could be developed for comparative analysis in the framework.

Each of the concept demonstrations are presented in direct comparison to a donothing scenario. This assumes that this improvement has already been evaluated at the project level and selected as the preferred alternative. This would not have to be the case for application of the framework, which could also be applied on a project level. For broader applications, e.g., statewide prioritization, this assumption will reduce the complexity of analysis.

Finally, it should be noted that other private economic analysis tools are available that require purchased software or data. While this methodology is developed as an alternative, in order to remove a cost barrier to agencies wishing to consider freight impacts, purchased software or data could confirm the accuracy of this analysis by validating the results. Although not available for this study, further comparison of this proposed framework with other economic analysis tools available for purchase is recommended for future research. 


\section{CHAPTER 8: TASK 6 - IMPLEMENTATION, DISCUSSION, CONCLUSIONS, AND RECOMMENDATIONS}

The results from this research have demonstrated how the framework can prioritize freight highway improvements. This chapter will present a vision for how this framework could be implemented in practice and identify potential funding sources to support the freight highway improvements recommended by the implemented framework. Overarching conclusions and recommendations based on this research and analysis are also presented.

\subsection{Implementation}

The implementation of a dedicated freight highway asset management system could lead to increased trucking industry support for providing funding for infrastructure projects. Currently, the use of freight performance measures in asset management is relatively rare. The revenue generated from truck-related taxes and fees generally is assigned to general infrastructure improvements. As such, generated highway revenue is combined from all user classes, funding is assigned to various projects without any specific regard for the freight sector that is not only a major user of infrastructure, but also the national economy.

This freight-focused asset management system would enable the public sector to view the highway system from the freight perspective. With the ability to highlight projects that would address freight highway needs, the public sector could reach out to the trucking industry. By showing the benefits and savings the trucking industry could derive from the prioritized infrastructure improvements, there might be increased support for public-private partnerships. Alternatively, a variety of policy or road user fee strategies focused on freight could be justified with this freight module in place to apply funds to prioritized projects that would address freight highway needs.

Under existing revenue generation mechanisms, this freight module could be applied to prioritize freight highway needs within existing funding streams, e.g., funds for safety improvements might be prioritized for select safety improvements that are particularly beneficial to the trucking sector. Alternatively, given the importance of the trucking sector to the national economy, this freight module for asset management could justify a percentage of funding from general highway funds be allocated specifically for freight highway improvements, alongside funds dedicated to transit and safety, for example.

However, given the current state of highway infrastructure, in general, and the continued decline of transportation funds generated from fuel taxes, it may not be desirable to restrict funding within an already strained existing revenue system. An exception to this might be if matching funds could be obtained through public-private partnerships, for example. A better approach might be to implement a new revenue generation mechanism to supplement existing funding sources. This supplemental revenue from the trucking industry could be allocated specifically for freight highway improvements. 
Numerous supplemental revenue generating mechanisms might be implemented for trucks, including additional annual trucks fees or taxes or a variety of truck vehiclemiles travelled fee approaches. A number of vehicle-miles travelled road user fee systems have been deployed or tested for a variety of objectives, including replacement of the fuel tax, congestion-based and demand management, environmental, facility-based revenue generation, and supplemental revenue generation. In particular, as shown in Table 28, several Central European countries and New Zealand impose tolls on heavy goods vehicles (HGV), i.e., trucks, in an effort to collect sufficient fees to be proportional with the costs that trucks impose on the highway infrastructure. In these existing systems, the proportional costs for highway wear and tear are measured by the number of axles or maximum laden weight. The motivation behind the implementation of most of these systems relates to increases in truck traffic in conjunction with funding shortfalls compared to the backlog of highway infrastructure needs.

These systems utilize a variety of technologies to serve data collection, communications and enforcement needs. Typically, the deployment requires on-board units and roadside gantries, then uses some combination of global positioning systems (GPS) technology, dedicated short-range communications (DSRC), automatic number plate recognition (ANPR), and/or cellular communications like Global System for Mobile (GSM) Communications.

Table 28. Existing truck-based road user fee deployments and characteristics

\begin{tabular}{|c|c|c|c|c|c|c|c|}
\hline \multirow[b]{2}{*}{$\begin{array}{l}\text { Country and Truck-based } \\
\text { Road User Fee System }\end{array}$} & \multicolumn{2}{|c|}{$\begin{array}{c}\text { Tolled } \\
\text { Roadways }\end{array}$} & \multicolumn{5}{|c|}{ Per-mile Fee Basis } \\
\hline & 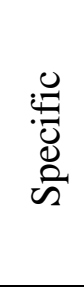 & $\bar{Z}$ & 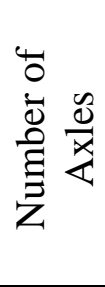 & 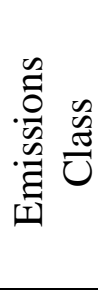 & 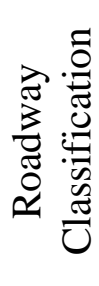 & 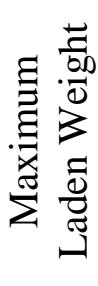 & .0 \\
\hline Germany, HGV Tolling & $\mathrm{X}$ & & $\mathrm{X}$ & $\mathrm{X}$ & & & \\
\hline Austria, GO-Maut (HGV Tolling) & $\mathrm{X}$ & & $\mathrm{X}$ & & & & \\
\hline Czech Republic, Truck Tolling & $X$ & & $\mathrm{X}$ & $\mathrm{X}$ & & & \\
\hline Slovak Republic, Truck Tolling & $\mathrm{X}$ & & $\mathrm{X}$ & $\mathrm{X}$ & $\mathrm{X}$ & & \\
\hline Switzerland, Heavy Vehicle Fee & & $\mathrm{X}$ & & $\mathrm{X}$ & & $\mathrm{X}$ & \\
\hline New Zealand, EROAD & & $\mathrm{X}$ & & & & $\mathrm{X}$ & $\mathrm{X}$ \\
\hline
\end{tabular}

Notes of interest for each of the various systems include:

- Germany: tolls range from $€ 0.09$ to $€ 0.14$ per kilometer (US $\$ 0.23$ to US $\$ 0.35$ per mile) and fund transportation problems; gross revenue in 2009 was about $€ 3.9$ billion (US $\$ 5$ billion).

- Austria: revenues from the system are earmarked for use on the charged roadway network, which does not receive funding from general revenues. 
- Czech Republic: a primary objective of the system is to capture revenues from foreign vehicles that were not viewed as fully contributing to the funding system; the system generated about US \$340 million in 2008.

- Slovak Republic: a relatively newer system than those in neighboring countries, this system started in 2010, and generated an estimated \$11.6 million in the first month of operation.

- Switzerland: with a foundation of freight pricing going back to 1983, the current program was implemented in 2001.

- New Zealand: this high technology deployment is touted as the "world's first network-wide autonomous Global Navigation Satellite System (GNSS) and cellular tolling system for heavy goods vehicles" (Bradley, 2011).

All of these systems serve as a model for a truck-based road user fee deployment in the United States that could assess and collect supplemental revenue for the purposes of funding prioritized freight highway infrastructure needs. Certainly, other mechanisms could also be employed to generate funding for freight-specific infrastructure needs. Examples of other mechanisms include the dedicated use of fuel taxes or licensing and registration fees that are assessed on trucks. Public private partnerships with the trucking industry might also be a possibility for generating freight-specific funds, although due to the vast number of stakeholders and independent operators, it would likely be overly difficult to be fair and reach consensus.

In conclusion, following the implementation of an asset management system that prioritizes freight highway infrastructure needs, dedicated revenue to fund these needs is required. Supplemental revenue assessed on trucks as a flat fee or based on vehicle-miles traveled are two approaches to accomplish this objective.

\subsection{Discussion Points}

A number of questions may remain about the proposed framework and how it may be adapted or implemented. A number of these questions will be addressed in this section.

Why are this framework and the proposed performance measures a good approach?

Numerous avenues were explored for developing economic measures to prioritize freight infrastructure needs. Ultimately, however, the Bureau of Economic Analysis' Regional Input-Output Modeling System and Federal Highway Administration's Freight Analysis Framework both contain a rich and robust data set that is publically available and can be used to examine any part of the country. The input-output model also has the benefit of being scalable to a national, state, or county-level (or any grouping of states or counties).

Another benefit of the input-output model is the ability of the user to manipulate the data in such a way as to forecast future impacts. The input-output model presents a snapshot in time. However, given the way industrial sectors are presented in the inputoutput model make and use tables, one could project impacts that could occur due to changing markets, such as a larger hydrogen market given the proliferation of hydrogenpowered vehicles and the need to transport hydrogen to fueling stations, for example. 
Overall, the proposed framework gives a valuable approach due to its flexibility for the user to manipulate the framework to meet various agency goals and generate a list of prioritized infrastructure needs. Because many agencies have constrained budgets and resources, the framework is developed around publically available data. Further, it is designed to allow the user to add or remove performance measures in the proposed freight module, as well as measures of excess trucking costs based on available data, and to place emphasis on certain priorities, e.g., safety or mobility, as desired. These features of the developed framework allow it to be user friendly, minimize costs, and more easily interface with existing asset management systems. Because the construction of freight-only highway facilities is relatively rare, the ability to integrate with existing asset management systems is important so that the freight impacts can be included into the highway infrastructure prioritization process.

\section{How does the proposed framework differ from available software?}

Other economic analysis tools available to practitioners tend to require purchased software or data. This cost might be a barrier to agencies wanting to begin a new initiative to consider freight impacts. The methodology developed here offers an alternative to a complex software analysis by using existing, easily obtained data sources for the development of the framework, understanding the already limited resources of transportation agencies. While some of the available software programs do use inputoutput modeling techniques, their proprietary nature does not allow for a side-by-side comparison of how their approach differs from the proposed framework in this research.

Why was the first proposed economic measure not recommended for use?

The metric of economic importance of commodities showed little proportional difference to the basic sum of kilotons carried on the routes or AADTT, as shown in Table 12 above. In other words, despite a potentially laborious process to develop route assignments for commodities to and from given regions, the results are not different from data already given by AADTT in the Freight Analysis Framework. This suggests that the commodities that will most impact the framework will be those that have a particularly high economic importance to the region or are of otherwise distinct regional significance.

This metric attempted to show the relative economic importance of highway links based on sectors most dependent upon the trucking sector. Instead of simply showing the value of the commodities being transported on the route, this measure tried to capture the importance of a route based on the quantity of commodities associated with truckdependent sectors. Using a disruption to the trucking sector in the inoperability inputoutput model, and an origin-destination model with route assignments for specific commodities of those truck-dependent sectors, a route on which more commodities of truck-dependent sectors were transported would have a higher value of economic importance.

What measures might be considered for excess trucking costs?

Only truck travel time savings and truck crash severity data were used to calculate excess trucking costs in the concept demonstration of the proposed framework.

However, depending upon the availability of this data from the state, or the desire to incorporate additional measures, many additional freight economic measures could, and 
should, be developed for comparative analysis in the framework. Examples of these measures might include environmental measures such as the excess cost of carbon emissions or excess trucking costs due to added wear and tear due to poor pavement quality.

Caution should be taken when developing and applying these measures in the proposed framework, however. Some excess costs, such as those of carbon emissions or even truck crashes, as calculated in the concept demonstration, will not directly apply to the measure of economic hindrance unless that cost is being borne by the trucking sector. For example, some of the excess trucking costs due to truck crashes are either societal costs, due to the lost productivity of the deceased individual, or borne by the insurance industry. Likewise, excess costs due to carbon emissions are currently borne by society and would only merit input to the third measure for economic hindrance if the trucking sector were being charged a carbon tax to account for those carbon emissions.

Based on the concept demonstrations, can this framework only be used for the prioritization of new construction programs?

This framework is applicable to asset management programs, as well as new construction programs. Although the concept demonstrations focused on two new construction projects, the framework could be applied to existing roadways also. As an example, an existing roadway with rough pavement might be proposed for resurfacing, which would reduce truck wear and tear, and thus reduce excess trucking costs.

Alternatively, this framework does not have to be applied solely for comparison of an existing and an improved state. Instead, it could be applied to measure the impacts of a do-nothing option by comparing an existing and a degraded state. With tightening budgets, transportation agencies may not have the funding to maintain all roadways to current standards; the proposed framework could be applied to show the excess trucking costs incurred by the degraded infrastructure, or in the event of infrastructure failure, the higher excess trucking costs due to increased travel times and distances of a longer alternate route around the infrastructure failure.

Are there other measures or methods that might be incorporated in the framework?

Many other performance measures exist that might be incorporated in the proposed framework. Further, as seen in the two concept demonstrations, there are also multiple ways to execute the proposed framework. As with many aspects of transportation planning and asset management, numerous approaches exist to solve the same problem. As an example, another way to compare values of excess trucking costs and the economic hindrance would not just be as a rate per mile, but as a rate per truck.

\subsection{Conclusions}

The freight sector plays an important role in the economy and depends on a reliable highway network, yet the needs of the freight sector are often overlooked by asset management programs that allocate funding for infrastructure maintenance and improvements. As such, this research presents an approach to address the inclusion of 
economic metrics to prioritize freight highway infrastructure. A summary of contributions of this research are that it:

1. Expands upon work by Crowther et al. (2004) and Haimes et al. (2001, 2004, 2005-a, 2005-b) on the inoperability input-output model by applying concepts from that research to transportation asset management, specifically freight highway infrastructure;

2. Develops new freight-based economic metrics to support the prioritization of highway infrastructure in light of the lack of any universally accepted or comprehensive set of performance measures that currently exist; and

3. Presents an approach that uses publically available data sources and can be integrated with existing asset management systems to minimize burdens to agency stakeholders.

This research offers other contributions that are also important to the fields of freight and transportation asset management by:

1. Advocating for the inclusion of freight considerations to existing highway asset management programs and planning processes due to the critical role trucking has in the economy and to highway systems;

2. Adapting the use of common, general performance measures of mobility and safety (e.g., travel times and crashes, which are also quantified as costs) to focus their application specifically on trucking by using a measure of excess trucking costs as both a direct and indirect economic measure for affecting shipping and industry costs;

3. Presenting freight performance measures that should be considered for inclusion to highway asset management programs to incorporate freight needs; and

4. Advocating for a dedicated funding mechanism to be linked with a freight highway asset management system.

The developed freight highway infrastructure framework, with further refinement, can be used as guidance for planners at state DOTs, MPOs, and even FHWA to consider economic importance of freight corridors and needs of the trucking industry to maintain a strong economy and smooth flow of goods. This tool may be used alongside existing prioritization frameworks and selectively implemented, if preferred. This freight infrastructure prioritization framework could be used fill gaps that currently exist in most asset management strategies by focusing on freight performance and economic importance of selected corridors. Doing so may demonstrate an incremental economic benefit to justify project selection for funding. This incremental benefit to the trucking sector is a real and important part of highway improvements that typically goes 
unmeasured currently. The demonstrated framework is one way to give practitioners this additional information to consider for project prioritization.

The concept demonstrations developed here illustrate how the framework can be applied to specific scenarios. In practice, all commodities from the input-output model and Freight Analysis Framework would be applied, but for sake of space and time, a limited number of commodities were selected for demonstration here. Although not used in this research, purchased data is available that could enhance the accuracy of the analysis.

As Table 12 showed above, the metric of economic importance of commodities showed little proportional difference to the basic sum of kilotons carried on the routes or AADTT. In other words, despite a potentially laborious process to develop route assignments for commodities to and from given regions, the results may not differ that much from data already given by AADTT in the Freight Analysis Framework. This suggests that the commodities that will most impact the framework will be those that have a particularly high economic importance to the region or are of otherwise distinct regional significance.

This said, it is believed that using the second and third proposed metrics (excess trucking cost and economic hindrance) together instead of the first metric (economic importance) may be a fuller depiction of the economic situation. In this way, a more common metric, excess trucking costs, which is relatively easy to develop for a variety of issues related to mobility, pavement condition, safety, etc., can be further extrapolated to present a fuller economic impact of the highway's deficiencies.

This is not to say that these metrics are ready for full implementation. A major assumption of this approach is that the metrics selected as economic metrics for the trucking sector can indeed be linked with infrastructure performance. Crowther et al. (2004) validates this assumption by using trucking sector disruptions in the inoperability input-output model as a direct link to highway infrastructure performance in the context of terrorism. Still, the values presented in Table 3 showing the percent disruption and dollar loss for each industry associated with a $100 \%$ disruption to the trucking sector reveal some potential concerns. Some of the industrial sectors most impacted by this disruption such as wholesale trade, and warehousing and storage seem to support this assumption that highway infrastructure can be directly linked with the trucking sector. However, the cause of high impacts to other industries like broadcasting and telecommunications, and management of companies and enterprises are less clear. Further, some of the sectors with the greatest disruptions are the motor vehicles, bodies and trailers; petroleum and coal products; and oil and gas extraction industrial sectors, which likely signify the loss of sales of vehicles and fuel to the trucking sector less than it reflects any impact due to infrastructure performance itself. Before widespread implementation of this framework, and specifically the economic metrics presented herein, further examination of this assumption will be necessary.

A second major assumption is made in the development of the third economic metric about economic hindrances due to inefficiencies of excess trucking costs. This metric assumes that all savings incurred by the trucking sector are passed back to other industries. By noting that small fluctuations in shipping costs may be absorbed by industries while larger cost increases are passed onto consumers in the form of higher prices, Emerson (2012) highlights a greater complexity than this assumption allows. In 
practice, it is more likely that the greater efficiencies incurred from reduced trucking costs will not be so exclusively direct to industries, but may also be passed along from those industries to consumers in order to maintain competitiveness. In other words, savings due to reduced excess trucking costs are likely to be divided amongst the trucking sector, industries, and consumers.

The metrics developed in this research are based on a complex methodology that still requires further refinement and validation. Due to inherent difficulties with predicting economic outcomes from a single highway improvement due to numerous exogenous factors associated with such diverse and widespread industries, no single validation approach can comprehensively evaluate the economic metrics developed herein without numerous additional assumptions in comparing the findings. Wherever possible, assumptions have been stated to present potential drawbacks of the developed economic metrics. Likewise, logic has been similarly applied and explained to present the potential value in using these economic metrics.

\subsection{Recommendations}

Numerous recommendations can be drawn from this research. The first and foremost recommendation, as well as a motivation for this research, is an appeal to highway agencies to include freight metrics in asset management programs. Freight plays a significant role in the national, state, and local economies and is highly dependent on the provision of a reliable highway network for success. This research highlights and has developed numerous freight-based performance measures that might be included into asset management programs with further refinement, and develops a framework for including additional economic-based performance measures that can be done using publically available datasets that are robust and applicable nationwide.

As to the methodology and developed economic metrics presented herein, there is a recommendation for future research. In order to verify, validate, and establish any new performance measures, specifically the freight economic metrics developed here, additional case studies need to be developed to demonstrate this framework, which is based on a complex methodology, numerous exogenous factors associated with the economy and trucking sector, and several major assumptions. Further calibration and sensitivity analyses need to be conducted as well. Validating outputs of economic-based measures of expected savings due to an infrastructure improvement, such as those developed here is particularly difficult, given the difficulty in obtaining quality data from all of the stakeholders impacted, but would also be of value. Finally, any well-tested metric will need to be linked with existing state asset management systems, which may require further testing, calibration, and demonstration. 


\section{REFERENCES}

1. Adams, T., Bittner, J., and Cook, S. "Develop an Asset Management Tool for Collecting and Tracking Commitments on Selected Environmental Mitigation Features." University of Wisconsin - Madison, 2009.

2. American Association of State Highway Transportation Officials (AASHTO). "Bridging the Gap: Restoring and Rebuilding the Nation's Bridges." 2008. 9 Nov 2009 〈http://www.transportation1.org/BridgeReport>.

3. American Association of State Highway Transportation Officials (AASHTO). "State DOT Performance Management Programs: Select Examples." 2007-a. 23 Aug 2010 <http://www.transportation1.org/tif6sreport/TIF\%206s.pdf>.

4. American Association of State Highway Transportation Officials (AASHTO). "Transportation Asset Management Today." 2010. 20 Aug 2010 $\langle$ http://assetmanagement.transportation.org/tam.aashto.nsf $>$.

5. American Association of State Highway Transportation Officials (AASHTO). "Transportation Invest in Our Future - A Vision for the $21^{\text {st }}$ Century." 2007-b. 10 Aug $2010<$ http://www.transportation1.org/tif5report>.

6. American Road \& Transportation Builders Association (ARTBA). "SAFETEA-LU and Critical Commerce Corridors." 2010. 10 Aug 2010 $<$ http://www.artba.org/advocacy/government-affairs/safetea-lu-and-criticalcommerce-corridors $>$.

7. American Society of Civil Engineers (ASCE). "Report Card for America's Infrastructure." 2009. 9 Nov $2009<$ http://www.infrastructurereportcard.org/index $>$.

8. American Transportation Research Institute (ATRI). FPMweb. 2010. 17 Aug 2010 <https://www.freightperformance.org/fpmweb>.

9. American Transportation Research Institute (ATRI). "Freight Performance Measures 2009 Bottleneck Analysis." Arlington, VA, 2009. 17 Aug $2010<$ http://www.atrinputoutputnline.org/index.php?option=com_content \&view=article\&id=248\&Itemid=75> .

10. Beagan, D. and Grenzeback, L. "Freight Impacts on Ohio's Roadway System." Cambridge Systematics, Inc. and Federal Highway Administration. 2002.

11. Bernardin, Jr., A. L. and Durango-Cohen, P. "Transportation Asset Management for Local Government Agencies." Midwest Regional University Transportation Center University of Wisconsin-Madison. Madison, WI, 2006.

12. Bradley, Nick. Life of Brian. Tolltrans, Traffic Technology International: 38-41. 2011. 
13. Burbank, C. J. "Strategies for Reducing the Impacts of Surface Transportation on Global Climate Change: A Synthesis of Policy Research and State and Local Mitigation Strategies." Parsons Brinckerhoff and American Association of State Highway and Transportation Officials (AASHTO). 2009. 17 Aug 2010 <http://www.climatestrategies.us/ewebeditpro/items/O25F22351.pdf>.

14. Bureau of Economic Analysis (BEA). "Regional Input-Output Modeling System (RIMS II)." 2010. 2 Feb 2011 <http://www.bea.gov/regional/rims >.

15. Bureau of Transportation Statistics (BTS). "National Transportation Statistics." Research and Innovative Technology Administration. Washington, D.C., 2011. 17 July $2012<$ http://www.bts.gov/publications/national_transportation_statistics>.

16. Bureau of Transportation Statistics (BTS) and U.S. Census Bureau. "2012 Commodity Flow Survey Standard Classification of Transported Goods (SCTG), SCTG Commodity Codes.” Washington, D.C., 2011.

17. Cafiso, S., Graziano, A. D., Kerali, H. R., and Odoki, J. B. "Multicriteria Analysis Method for Pavement Maintenance Management." Transportation Research Record: Journal of the Transportation Research Board, No. 1816. Transportation Research Board of the National Academies, Washington, D.C., 2002, pp. 73-84.

18. Cambridge Systematics, Inc. "NCHRP Report 446: A Guidebook for PerformanceBased Transportation Planning." Transportation Research Board - National Research Council. Washington, D.C., 2000.

19. Cambridge Systematics, Inc. "SHRP 2 Report: Performance Measurement Framework for Highway Capacity Decision Making." Transportation Research Board of the National Academies. Washington, D.C., 2009-a.

20. Cambridge Systematics, Inc. "Virginia Statewide Multimodal Freight Study" Virginia Department of Transportation, Office of Intermodal Planning and Investment. Phase 1, 2009-b. Phase 2, 2010.

21. Cambridge Systematics, Inc., Applied Research Associates, Inc., Arora and Associates, KLS Engineering, PB Consult, Inc., and Lambert, L. "NCHRP Report 632: An Asset Management Framework for the Interstate Highway System." Transportation Research Board of the National Academies. Washington, D.C., 2009.

22. Cambridge Systematics, Inc., Global Insight (formerly Reebie Associates), Cohen, H., Horowitz, A., and Pendyala, R. "NCHRP Report 606: Forecasting Statewide Freight Toolkit." Transportation Research Board of the National Academies. Washington, D.C., 2008. 
23. Cambridge Systematics, Inc. and Meyer, M. D. "U. S. Domestic Scan Program: Best Practices in Transportation Asset Management." NCHRP Project 20-68. Transportation Research Board of the National Academies. Washington, D.C., 2007.

24. Cambridge Systematics, Inc., Parsons Brinckerhoff, and Venner Consulting, Inc. "NCHRP Web-Only Document 103: Final Report for NCHRP Research Results Digest 317: Prototype Software for an Environmental Information Management and Decision Support System." Transportation Research Board of the National Academies. Washington, D.C., 2006-a. 18 Aug 2010 <http://onlinepubs.trb.org/onlinepubs/nchrp/nchrp_w103.pdf $>$.

25. Cambridge Systematics, Inc., PB Consult, and System Metrics Group. "NCHRP Report 545: Analytical Tools for Asset Management." Transportation Research Board of the National Academies. Washington, D.C., 2005.

26. Cambridge Systematics, Inc., PB Consult, Inc., and Texas Transportation Institute. "NCHRP Report 551: Performance Measures and Targets for Transportation Asset Management." Transportation Research Board of the National Academies. Washington, D.C., 2006-b.

27. Cambridge Systematics, Inc., TransManagement, Inc., TransTech Management, Inc., and Heanue, K. "NCHRP Report 570: Guidebook for Freight Policy, Planning, and Programming in Small- and Medium-Sized Metropolitan Areas." Transportation Research Board of the National Academies, Washington, D.C., 2007.

28. Carroll, D. A., Cheng, R., Eger III, R. J., Grusczynski, L., Marlowe, J., and Titi, H. H. "Implementing Highway Preventative Maintenance: Comparing Challenges, Processes, and Solutions in Three States." Transportation Research Record: Journal of the Transportation Research Board, No. 1877. Transportation Research Board of the National Academies, Washington, D.C., 2004, pp. 10-16.

29. Cascetta, E. "Transportation Systems Engineering: Theory and Methods." Kluwer Academic Publishers, The Netherlands, 2001.

30. Chase, K. M., Anater, P., and Phelan, T. "The Second Strategic Highway Research Program (SHRP 2) Freight Demand Modeling and Data Improvement." Transportation Research Board, Washington, D.C., 2013.

31. Chowdhury, M. A., Tan, P., and William, S. L. "An Interactive Multiobjective Decision Support Framework for Transportation Investment.” Midwest Regional University Transportation Center, University of Wisconsin - Madison, 2002.

32. Commonwealth of Virginia, Office of Intermodal Planning and Investment (VTrans). "Freight Impacts on the Environment and Energy Usage." 2008. 17 Aug 2010 <http://www.vtrans.org/resources/Freight_Impacts_on_the_Environment.pdf>. 
33. Crowther, K. G., Dicdican, R. Y., Leung, M. F., Lian, C., Williams, G. M., Haimes, Y. Y., Lambert, J. H., Horowitz, B. M., and Santos, J. R. "Assessing and Managing Risk of Terrorism to Virginia's Interdependent Transportation Systems." Virginia Transportation Research Council, Charlottesville, Virginia. 2004.

34. Czerniak, R., Gaiser S., and Gerard, D. "The Use of Intermodal Performance Measures by State Departments of Transportation." Federal Highway Administration, Office of Environment and Planning. Washington, D.C., 1996.

35. Dicdican, R. Y., Haimes, Y. Y., and Lambert, J. H. "Risk-based Asset Management Methodology for Highway Infrastructure Systems." Virginia Transportation Research Council, Virginia Department of Transportation. Charlottesville, Virginia. 2004.

36. Emerson, L. "Higher gas prices affect prices of other consumer goods." The Augusta Chronicle. Augusta, Georgia, 2012.

37. Eno Transportation Foundation, Inc. "Economic Returns from Transportation Investment." Landsdowne, VA, 1996. 17 July 2012 <https://www.fhwa.dot.gov/policy/otps/060320a/060320a.pdf>.

38. Eno Transportation Foundation, Inc. "Transportation Investment: New Insights from Economic Analysis.” Washington, D.C., 1999. 17 July 2012 <https://www.fhwa.dot.gov/policy/otps/060320e/060320e.pdf $>$.

39. European Conference of Ministers of Transport (ECMT). "Transport and Economic Development," Report of the $119^{\text {th }}$ Round Table on Transport Economics, Paris. 2002.

40. European Environment Agency (EEA). "Success stories within the road transport sector on reducing greenhouse gas emission and producing ancillary benefits." Copenhagen, 2008. 17 Aug 2010 <http://www.eea.europa.eu/publications/technical_report_2008_2>.

41. Falcocchio, J. C. "Performance Measures for Evaluating Transportation Systems: Stakeholder Perspective." Transportation Research Record: Journal of the Transportation Research Board, No. 1895. Transportation Research Board of the National Academies, Washington, D.C., 2004, pp. 220-227.

42. Falls, L. C., Haas, R., and Tighe, S. "Asset Service Index as Integration Mechanism for Civil Infrastructure." Transportation Research Record: Journal of the Transportation Research Board, No. 1957. Transportation Research Board of the National Academies, Washington, D.C., 2006, pp. 1-7. 
43. Federal Highway Administration (FHWA). "2006 Status of the Nation's Highways, Bridges and Transit: Conditions and Performance." Appendix B: Bridge Inventory Analysis Methodology. Washington, D.C., 2007. 19 Nov 2009 <http://www.fhwa.dot.gov/policy/2006cpr/appb.htm>.

44. Federal Highway Administration (FHWA). Asset Management. "HERS-ST Highway Economic Requirements System - State Version," "Bridge Management," "Economic Analysis Primer," and "Asset Management Overview." Washington, D.C., 2008-a. 20 Aug 2010 <http://www.fhwa.dot.gov/infrastructure/asstmgmt $>$.

45. Federal Highway Administration (FHWA), Design. "Interstate System - Design." Washington, D.C., 2009-a. 10 Aug 2010 <http://www.fhwa.dot.gov/programadmin/interstate.cfm $>$.

46. Federal Highway Administration (FHWA). Freight Management and Operations. "Freight Analysis Framework," "Freight Story 2008," "Freight Transportation: Improvements and the Economy," and "Performance Measurement." Washington, D.C., 2010-a. 17 July 2012 <http://ops.fhwa.dot.gov/freight>.

47. Federal Highway Administration (FHWA). Freight Management and Operations. "Freight Facts and Figures 2011." Washington, D.C., 2012. 13 Nov 2012 <http://ops.fhwa.dot.gov/freight/resources/current_news/news.cfm?ID=565> .

48. Federal Highway Administration (FHWA), Office of Engineering, Bridge Division. "Recording and Coding Guide for the Structure Inventory and Appraisal of the Nation's Bridges.” Washington, D.C., 1995. 17 Aug 2010 <http://www.fhwa.dot.gov/bridge/mtguide.pdf $>$.

49. Federal Highway Administration (FHWA). Office of Policy, Office of International Programs. "Transportation Performance Measures in Australia, Canada, Japan, and New Zealand.” Washington, D.C., 2004. 11 Aug 2010 <http://international.fhwa.dot.gov/performance/04transperfmeasure.pdf $>$.

50. Federal Highway Administration (FHWA). Office of Transportation Policy Studies. "Estimated Cost of Freight Involved in Highway Bottlenecks." Washington, D.C., 2008-b. 17 Aug 2010. 〈http://www.fhwa.dot.gov/policy/otps/freight.cfm>.

51. Federal Highway Administration (FHWA). Office of Transportation Policy Studies. "Productivity and the Highway Network: A Look at the Economic Benefits to Industry from Investment in the Highway Network." Washington, D.C., 1996. 17 July 2012 <http://www.fhwa.dot.gov/policy/otps/060320b/060320b.pdf >.

52. Federal Highway Administration (FHWA). Office of Transportation Policy Studies. "Truck Size and Weight Study." Washington, D.C., 2006. 19 Nov 2009 <http://www.fhwa.dot.gov/policy/otps/truck/index.htm >. 
53. Federal Highway Administration (FHWA), Planning, Environment and Realty. "National Highway System." Washington, D.C., 2010-b. 10 Aug 2010 <http://www.fhwa.dot.gov/planning/nhs $>$.

54. Federal Highway Administration (FHWA), Policy Information. "Highway Performance Monitoring System.” Washington, D.C., 2009-b. 12 Aug 2010 <http://www.fhwa.dot.gov/policy/ohpi/hpms $>$.

55. Federal Highway Administration (FHWA), Turner-Fairbank Highway Research Center. "Highway Safety Information System." Washington, D.C., 2010-c. 16 Aug $2010<$ http://www.hsisinfo.org>.

56. Federal Highway Administration (FHWA) and Virginia Department of Transportation (VDOT) "Route 460 Location Study, Draft Environmental Impact Statement." 2005.

57. Federal Motor Carrier Safety Administration (FMCSA). "Current FMCSA Crash Cost Figures." 2008. 25 Nov 2012

<http://mcsac.fmcsa.dot.gov/documents/Dec09/FMCSACrashCostCalculationsDec08 .pdf $>$.

58. Forkenbrock, D. J. and Weisbrod, G. E. "NCHRP Report 456: Guidebook for Assessing the Social and Economic Effects of Transportation Projects." Transportation Research Board - National Research Council. Washington, D.C., 2001.

59. Garber, N. J. and Hoel, L. A. "Traffic \& Highway Engineering," 4 th ed. Cengage Learning. 2009.

60. Guerre, J. A., Robert, W. E., Bradbury, A., and Goodale, M. "The Executive Support System of Ontario Canada: Integrating Pavement and Bridge Management Systems." Transportation Research Record: Journal of the Transportation Research Board, No. 1933. Transportation Research Board of the National Academies, Washington, D.C., 2005, pp. 27-34.

61. Haggerty, M. S., Santos, J. R., and Haimes, Y. Y. “Transportation-Based Framework for Deriving Perturbations to the Inoperability Input-Output Model.” Journal of Infrastructure Systems. Vol. 14, No. 4. 2008.

62. Hagler Bailly Services, Inc. "Measuring Improvements in the Movement of Highway and Intermodal Freight.” Federal Highway Administration, Washington, D.C., 2000. 
63. Haimes, Y. Y., Ferguson, W. S., and Mondul, S. M. "Risk Assessment and Management of Critical Highway Infrastructure." Virginia Transportation Research Council, Virginia Department of Transportation. Charlottesville, Virginia. 2004.

64. Haimes, Y. Y., Horowitz, B. M., Lambert, J. H., Santos, J. R., Lian, C., and Crowther, K. G. "Inoperability Input-Output Model for Interdependent Infrastructure Sectors. I: Theory and Methodology." Journal of Infrastructure Systems. Vol. 11, No. 2. 2005-a.

65. Haimes, Y. Y., Horowitz, B. M., Lambert, J. H., Santos, J., Crowther, K., and Lian, C. "Inoperability Input-Output Model for Interdependent Infrastructure Sectors. II: Case Studies." Journal of Infrastructure Systems. Vol. 11, No. 2. 2005-b.

66. Haimes, Y. Y. and Jiang, P. "Leontif-Based Model of Risk in Complex Interconnected Infrastructures.” Journal of Infrastructure Systems. Vol. 7, No. 1. 2001.

67. Haimes, Y. Y., Lambert, J. H., Frohwein, H. I., Schiff, L. A., and Hashemi, P. K. “A Tool to Aid the Comparison of Improvement Projects for the Virginia Department of Transportation." Virginia Transportation Research Council, Virginia Department of Transportation. Charlottesville, Virginia. 1998.

68. Haimes, Y. Y., Lambert, J. H., Kaplan, S., Pikus, I., Leung, F., and Ferguson, W. S. "A Risk Assessment Methodology for Critical Transportation Infrastructure." Virginia Transportation Research Council, Virginia Department of Transportation. Charlottesville, Virginia. 2002.

69. Hajek, J. J. and Billing, J. R. "Trucking Trends and Changes that Affect Pavements." Transportation Research Record: Journal of the Transportation Research Board, No. 1816. Transportation Research Board of the National Academies, Washington, D.C., 2002, pp. 96-103.

70. Harrison, R., Schofield, M., Loftus-Otway, L., Middleton, D., and West, J. "Developing Freight Highway Corridor Performance Measure Strategies in Texas." Center for Transportation Research, The University of Texas at Austin. Austin, TX, 2006.

71. Heaslip, K., Louisell, W., and Collura, J. "A Methodology to Evaluate Transportation Resiliency for Regional Networks." Transportation Research Board $88^{\text {th }}$ Annual Meeting. CD-ROM. Washington, D.C., 2009.

72. Hedlund, J. "Traffic Safety Performance Measures for States and Federal Agencies." National Highway Traffic Safety Administration (NHTSA). Washington, D.C., 2008. 23 Aug 2010 
<http://www.nhtsa.gov/DOT/NHTSA/Traffic\%20Injury\%20Control/Articles/Associa ted\%20Files/811025.pdf $>$.

73. Hoel, L. A., Drake, J. S., Coyle, J. J., Davinroy, T. B., DiCesare, F., Enns, M. K., Herendeen, J. H., Pashek, R. D., Sauerlender, O. H., Sridharan, R., Womer, N. K. "Methodological Framework for Comprehensive Transportation Planning." Transportation Research Institute, Carnegie-Mellon University and Pennsylvania Transportation and Traffic Safety Center, Pennsylvania State University. 1967.

74. Intelligent Transportation Society of America (ITSA). "National Intelligent Transportation Systems Program Plan: A Ten-Year Vision.” 2002. 17 Aug 2010 $<$ http://www.itsa.org/itsa/files/pdf/National10YearPlanITSFull.pdf>.

75. "International Infrastructure Management Manual" (IIMM), $3^{\text {rd }}$ ed. Association of Local Government Engineering N.Z., Inc. (INGENIUM) and National Asset Management Steering (NAMS) Group. New Zealand, 2006.

76. Isard, W. "Methods of Regional Analysis: An Introduction to Regional Science." Masssachusetts Institute of Technology, The M.I.T. Press. Cambridge, Massachusetts, 1960.

77. Lambert, J. H., Joshi, N. N., Peterson, K. D., Wadie, S. M. "Coordination and Diversification of Investments in Multimodal Transportation." Public Works Management \& Policy. 2007.

78. Larson, M. C. and Berndt, M. "Freight Performance Measures: A Yardstick for Minnesota's Transportation System: Recommendations of the Minnesota Freight Advisory Committee.” Minnesota Department of Transportation, Measurement and Evaluation Section and Office of Freight, Rail and Waterways. 1999.

79. Li, J., Muench, S. T., Mahoney, J. P., Sivaneswaran, N., Pierce, L. M., and White, G. C. "The Highway Development and Management System in Washington State: Calibration and Application for the Department of Transportation Road Network." Transportation Research Record: Journal of the Transportation Research Board, No. 1933. Transportation Research Board of the National Academies, Washington, D.C., 2005, pp. 53-61.

80. Li, Z. and Madanu, S. "Highway Project Level Life-Cycle Benefit/Cost Analysis Under Certainty, Risk, and Uncertainty: A Methodology with Case Study." Journal of Transportation Engineering, Vol. 135, No. 8. American Society of Civil Engineering, 2009, pp. 516-526.

81. Li, Z. and Sinha, K. C. "Methodology for Multicriteria Decision Making in Highway Asset Management." Transportation Research Record: Journal of the Transportation 
Research Board, No. 1885. Transportation Research Board of the National Academies, Washington, D.C., 2004, pp. 79-87.

82. Lownes, N. and Zofka, A. "Applying Transportation Asset Management in Connecticut." The Connecticut Academy of Science and Engineering. Hartford, CT, 2008.

83. Mahady, F. X. and Lahr, M. L. "Endogenous Regional Economic Growth Through Transportation Investment." Transportation Research Record: Journal of the Transportation Research Board, No. 2067. Transportation Research Board of the National Academies, Washington, D.C., 2008, pp. 110-119.

84. Markow, M. J. "NCHRP Synthesis 371: Managing Selected Transportation Assets: Signals, Lighting, Signs, Pavement Markings, Culverts, and Sidewalks." Transportation Research Board of the National Academies. Washington, D.C., 2007.

85. Martin, W. A. and McGuckin N. A. 'NCHRP Report 365: Travel Estimation Techniques for Urban Planning.” pp 100-103. Transportation Research Board, National Research Council. Washington, D.C., 1998.

86. McMullen, B. S. "Multimodal Freight Investment Criteria." Oregon Department of Transportation, Salem, OR, 2010. 17 July 2012 <http://www.oregon.gov/ODOT/TD/TP RES/docs/Reports/2010/Multimodal Invest ment_Criteria.pdf>.

87. Meyer, M. "Measuring That Which Cannot Be Measured-At Least According to Conventional Wisdom." Performance Measures to Improve Transportation Systems and Agency Operations: Report of a Conference. Conference Proceedings 26. Transportation Research Board of the National Academies. Washington, D.C., 2001. pp. 105-125.

88. Miller, J. S., Turochy, R. E., and Lambert, J. H. "Considerations in the Development of Procedures for Prioritizing Transportation Improvement Projects in Virginia." Virginia Transportation Research Council, Virginia Department of Transportation. Charlottesville, Virginia. 2002.

89. Nadiri, M. I. and Mamuneas, T. P. "Contribution of Highway Capital to Industry and National Productivity Growth," 1996 and "Contribution of Highway Capital to Output and Productivity Growth in the US Economy and Industries." Federal Highway Administration, Office of Policy Development, Washington, D.C. 17 July $2012<$ http://ntl.bts.gov/lib/5000/5800/5807/growth.pdf>, <https://www.fhwa.dot.gov/policy/gro98cvr.htm>. 
90. National Cooperative Highway Research Program, Project 20-24(23). Transportation Research Board of the National Academies, Washington, D.C., 2007. 17 July 2012 <http://apps.trb.org/cmsfeed/TRBNetProjectDisplay.asp?ProjectID=534>.

91. National Highway Traffic Safety Administration (NHTSA). Fatality Analysis Reporting System Encyclopedia. 16 Aug $2010<\underline{\text { http://www- }}$ fars.nhtsa.dot.gov/Main/index.aspx $>$.

92. Neumann, L. A. "NCHRP Synthesis 243: Methods for Capital Programming and Project Selection." Transportation Research Board - National Research Council. Washington, D.C., 1997.

93. Oregon Department of Transportation (ODOT). "Federal Vehicle Classes and Definitions." 2012. 22 Nov 2012 <http://www.oregon.gov/ODOT/TD/TDATA/tsm/docs/FHWA_Veh_Classes.pdf>.

94. Pagano, A. M., McNeil, S., and Ogard, E. "Linking Asset Management to Strategic Planning Processes: Best Practices from State Departments of Transportation." Transportation Research Record: Journal of the Transportation Research Board, No. 1924. Transportation Research Board of the National Academies, Washington, D.C., 2005, pp. 184-191.

95. Peters, J. R., Paaswell, R. E., and Berechman, J. "Economic Competitiveness: Performance Measures for Transportation." Region 2 - University Transportation Center, The City College of New York, New York City, New York, 2008. 17 July 2012 <http://www.utrc2.org/research/assets/139/C-06-28finalrept-Phase1.pdf>.

96. Poister, T. H. "NCHRP Sythesis 238: Performance Measurement in State Departments of Transportation." Transportation Research Board - National Research Council. Washington, D.C., 1997.

97. Potts, C. “Goods Movement on our Nation's Highways.” American Road and Transportation Builders Association (ARTBA). Testimony before U.S. Senate Committee on Environment and Public Works, 8 May 2008.

98. Proctor, G. D. TRB Joint Summer Meeting, "Planning and Performance Measurement for All Modes." Minneapolis Marriot City Center, Minneapolis, MN. 12 Jul 2010. Interim Findings from NCFRP 3 Performance Measures for Freight Transportation.

99. Reed, M. F., Luettich, R. A., and Lamm, L. P. "NCHRP Report 357: Measuring State Transportation Program Performance." Transportation Research Board - National Research Council. Washington, D.C., 1993. 
100. Reigle, J. A. and Zaniewski, J. P. "Risk-Based Life-Cycle Cost Analysis for Project-Level Pavement Management." Transportation Research Record: Journal of the Transportation Research Board, No. 1816. Transportation Research Board of the National Academies, Washington, D.C., 2002, pp. 34-42.

101. Richardson, J., Turner, D., Hale, D. P., and Sharpe, S. "Bridge Health Monitoring Metrics: Updating the Bridge Deficiency Algorithm." Aging Infrastructure Systems Center of Excellence and University Transportation Center for Alabama, The University of Alabama. 2009.

102. Rico, A., Mendoza, A., and Mayoral, E. "Applications of Economic Value of Freight Flows to Transport Planning." Transportation Research Record: Journal of the Transportation Research Board, No. 1522. Transportation Research Board of the National Academies, Washington, D.C., 1996.

103. Robert, W. E. and Gurenich, D. I. "Modeling Approach of the National Bridge Investment Analysis System.” Cambridge Systematics, Inc. International Bridge and Structure Management: Tenth International Conference on Bridge and Structure Management, 20-22 Oct 2008, Buffalo, NY. Transportation Research E-Circular. Transportation Research Board of the National Academies. 20 Aug 2010 <http://onlinepubs.trb.org/onlinepubs/circulars/ec128.pdf $>$.

104. Rodrigue, J.-P., Comtois, C., and Slack, B. "The Geography of Transport Systems," $2^{\text {nd }}$ ed. Routledge, London. 2009.

105. Santos, J. R. "Interdependency Analysis: Extensions to Demand Reduction Inoperability Input-Output Modeling and Portfolio Selection.” Ph.D. Dissertation. University of Virginia, Charlottesville, Virginia. 2003.

106. Schrank, D., Lomax, T., and Turner, S. "TTI's 2010 Urban Mobility Report Powered by INRIX Traffic Data.” Texas Transportation Institute, The Texas A\&M University System. 2010. 17 July 2012 <http://tti.tamu.edu/documents/ums/mobility_report_2010_wappx.pdf>.

107. Schultz, G. G., Braley, K. T., and Boschert, T. "Prioritizing Access Management Implementation." Transportation Research Record: Journal of the Transportation Research Board, No. 2092. Transportation Research Board of the National Academies, Washington, D.C., 2009, pp. 57-65.

108. Shaw, T. and PBS\&J. "NCHRP Synthesis 311: Performance Measures of Operational Effectiveness for Highway Segments and Systems." Transportation Research Board of the National Academies, Washington, D.C., 2003. 
109. Shepard, R. W. and Johnson, M. B. "California Bridge Health Index." Transportation Research Board - National Research Council. Washington, D.C., 1999.

110. Shufon, J. J. and Adams, L. H. "Concept Framework for Defining and Developing an Integrated Asset Management System.” Transportation Research Record: Journal of the Transportation Research Board, No. 1848. Transportation Research Board of the National Academies, Washington, D.C., 2003, pp. 37-44.

111. Sinha, K. C. and Labi, S. "Transportation Decision Making: Principles of Project Evaluation and Decision Making." John Wiley \& Sons, Inc., Hoboken, New Jersey. 2007.

112. Slater, R. E. "The National Highway System: A Commitment to America's Future." Public Roads, Vol. 59, No. 4. Federal Highway Administration, Washington, D.C., 1996. 10 Aug 2010 <http://www.fhwa.dot.gov/publications/publicroads/96spring/p96sp2.cfm>.

113. Souleyrette, R., Maze, T. H., Strauss, T., Pressig, D., and Smadi, A. G. "Freight Planning Typology." Transportation Research Record: Journal of the Transportation Research Board, No. 1613. Transportation Research Board of the National Academies, Washington, D.C., 1998.

114. Southworth, F., Peterson, B. E., Hwang, H.-L., Chin, S.-M., and Davidson, D. "The Freight Analysis Framework Version 3 (FAF3), A Description of the FAF3 Regional Database and How It Is Constructed." Federal Highway Administration, Office of Freight Management and Operations. 2011.

115. Stephanos, P., Dorsey, P., and Hedfi, A. "Maryland State Highway Administration's Project Selection Process: Integrating Network and Project-Level Analysis." Transportation Research Record: Journal of the Transportation Research Board, No. 1816. Transportation Research Board of the National Academies, Washington, D.C., 2002, pp. 16-25.

116. TransTech Management, Inc. "Strategic Performance Measures for State Departments of Transportation, A Handbook for CEOs and Executives." NCHRP Project No. 20-24(20). Transportation Research Board - National Research Council, Washington, D.C., 2003.

117. United States Census Bureau. Commodity Flow Survey, 2007. 1 Sep 2010 $<$ http://factfinder.census.gov/servlet/EconSectorServlet?caller=dataset\&sv_name $=20$

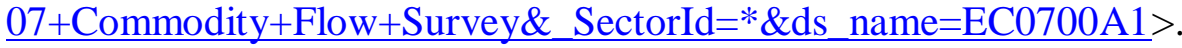

118. United States Department of Homeland Security. "Transportation Systems: Critical Infrastructure and Key Resources Sector-Specific Plan as input to the National 
Infrastructure Protection Plan.” Washington, D.C., 2007.

119. United States General Accounting Office (USGAO). "Highway Infrastructure, FHWA's Model for Estimating Highway Needs Has Been Modified for State-Level Planning." 2001. 20 Aug $2010<$ http://www.gao.gov/new.items/d01299.pdf>.

120. University of Michigan Transportation Research Institute. "Collection, Analysis and Evaluation of Commercial Motor Vehicles Safety Data (TIFA/BIFA).” 2010. 28 Nov $2010<$ http://www.umtri.umich.edu/project.php?wipID=64>.

121. Varma, Amiy. "Measurement Sources for Freight Performance Measures and Indicators." North Dakota State University, Department of Civil Engineering. Fargo, ND, 2008. 17 July 2012 <http://www.lrrb.org/pdf/200812.pdf $>$.

122. Victoria Transport Policy Institute (VTPI). "Transportation Cost and Benefit Analysis: Techniques, Estimates and Implications." $2^{\text {nd }}$ ed. Victoria, British Columbia, 2009. 17 July 2012 <http://www.vtpi.org/tca〉.

123. Virginia Department of Transportation (VDOT). "Highway Safety Improvement Program.” Crash Data Summaries, 2003-2007. 2012-a. 22 Nov 2012 <http://www.virginiadot.org/business/ted app pro.asp $>$.

124. Virginia Department of Transportation (VDOT) 2005, 2006, 2007 “Traffic Data Daily Vehicle Miles Traveled." 2012-b. 22 Nov 2012 <http://www.virginiadot.org/info/resources/VMTReport_220_2005.pdf>, $<$ http://www.virginiadot.org/info/resources/VMTReport_220_2006.pdf $>$, and $\langle$ http://www.virginiadot.org/info/resources/VMTReport_220_2007.pdf $>$.

125. Virginia Department of Transportation (VDOT). "U.S. Route 460 Corridor Improvements Project." 2012-c. 22 Feb 2012 $<$ http://www.route460ppta.org/project_objectives.asp $>$.

126. Virginia Department of Transportation (VDOT). "VDOT Projects and Studies, Route 29 Bypass.” 2012-d. 8 July 2012 <http://www.virginiadot.org/projects/culpeper/rt. 29 bypass.asp>.

127. Voigtlaender, N. "A Dynamic Input-Output Model to Project U.S. Freight Transportation Demand." Massachusetts Institute of Technology, Cambridge, Massachusetts, 2002.

128. Volpe National Transportation Systems Center. "Risk Assessment and Prioritization.” Volpe Journal. Cambridge, MA, 2003. pp. 4-13. 
129. Walls III, J. and Smith, M. R. "Life-Cycle Cost Analysis in Pavement Design Interim Technical Bulletin." Federal Highway Administration, Office of Engineering. 1998. 6 Sep 2010 〈http://isddc.dot.gov/OLPFiles/FHWA/013017.pdf〉.

130. Weed, R. M., Schmitt, R. L., Owasu-Ababio, S., and Nordheim, E. V. "Ranking Procedure Based on Statistical Hypothesis Testing." Transportation Research Record: Journal of the Transportation Research Board, No. 1991. Transportation Research Board of the National Academies, Washington, D.C., 2007, pp. 12-18.

131. Wei, C. and Tighe, S. "Development of Preventative Maintenance Decision Trees Based on Cost-Effectiveness Analysis." Transportation Research Record: Journal of the Transportation Research Board, No. 1866. Transportation Research Board of the National Academies, Washington, D.C., 2004, pp. 9-19.

132. Wood, Howard P. "NCFRP Web-Only Document 3, NCHRP Web-Only Document 185; Truck Tolling: Understanding Industry Tradeoffs When Using or Avoiding Toll Facilities." Transportation Research Board of the National Academies, Washington, D.C., 2011. 


\section{APPENDIX A - INTRA-STATEWIDE DEMONSTRATION OF PROPOSED ECONOMIC METRIC DEVELOPMENT METHODOLOGY USING 12 COMMODITIES IN VIRGINIA}

An application of the methodology depicted in Figure 2 is described here. The tables and figures below demonstrate a model example that uses a sample of data obtained from relevant literature and the FAF. Further refinements have been included in the developed model that was applied to case studies, using literature such as NCHRP Report 606 (Cambridge Systematics, et al., 2008) to improve route assignment and matches between commodity and industrial sector classifications; the following sample demonstration was assembled to provide further initial clarification by exhibiting one strategy to execute the aforementioned methodology for developing economic metrics.

1. Identify the most transportation-dependent industrial sectors. First, obtain the inputoutput (I-O) data from the Bureau of Economic Analysis (BEA) for the study area, which for this example is the entire state of Virginia. The BEA supplies this data for individual or combined county regions, states, groups of states, or the national level.

The BEA supplies "make" $(\mathbf{V})$ and "use" $(\mathbf{U})$ tables (shown in Tables B-1 and B-2, of Appendix B), which respectively show monetary values of column commodities produced by various row industries, and monetary values of row commodities consumed by various column industries. These tables can be used to generate first an input-output model, then the demand-based inoperability input-output model.

The relationships of commodity transactions between industries can be shown in a Leontif industry-by-industry technical coefficient matrix, $\mathbf{A}$. To generate $\mathbf{A}$, the BEA "make" (V) and "use" (U) tables must each be normalized by dividing every element by its column sum. The product of the normalized make $(\hat{\mathbf{V}})$ and normalized use $(\hat{\mathbf{U}})$ matrices is $\mathbf{A}$ :

$$
\mathbf{A}=\hat{\mathbf{V}} \hat{\mathbf{U}}
$$

Next, the total industry outputs, that is, the "normal" total production vector $\hat{\mathbf{x}}$ can be generated. This is calculated by multiplying the "make" table (V) and a unity vector $\Sigma$, whose elements are all ones and is also known as a summation vector. This equation is represented by:

$$
\hat{\mathbf{x}}=\mathbf{V} \Sigma
$$

The general equation for the I-O model is:

$$
\hat{\mathbf{x}}=\mathbf{A} \hat{\mathbf{x}}+\hat{\mathbf{c}}
$$

where: $\hat{\mathbf{x}}$ is the "normal" total production vector, in millions of dollars,

A is the Leontif coefficient matrix, multipliers,

$\hat{\mathbf{c}}$ is the "normal" final demand vector, in millions of dollars

Knowing $\mathbf{A}$ and $\hat{\mathbf{x}}$, as depicted below in, solve for $\hat{\mathbf{c}}$ with the general I-O equation, by subtracting the product $\mathbf{A} \hat{\mathbf{x}}$ from $\hat{\mathbf{x}}$ :

$$
\hat{\mathbf{c}}=\hat{\mathbf{x}}-\mathbf{A} \hat{\mathbf{x}}(\mathrm{A} 4)
$$




\begin{tabular}{|c|c|c|c|c|}
\hline $\mathbf{x}$ (derived) & A (deriv & & & c \\
\hline 9221 & 0.113 & 0.000 & 0.000 & 8179 \\
\hline 110434 & 0.017 & 0.062 & 0.051 & 101947 \\
\hline 29492 & 0.027 & 0.002 & 0.062 & 27243 \\
\hline
\end{tabular}

Figure A-1. Example vectors and Leontif coefficient matrix of the I-O model

A demand-based model, the inoperability I-O model, can be derived using the following transformation, which is also demonstrated below in Figure A-2:

$$
\mathbf{A}^{*}=[\operatorname{diag}(\hat{\mathbf{x}})]^{-1} \mathbf{A}[\operatorname{diag}(\hat{\mathbf{x}})]
$$

\begin{tabular}{rrr}
$\operatorname{diag}(\mathbf{x})^{-1}$ & & \\
\hline $1 \mathrm{E}-04$ & 0 & 0 \\
0 & $9 \mathrm{E}-06$ & 0 \\
0 & 0 & $3 \mathrm{E}-05$
\end{tabular}

\begin{tabular}{rrr}
$\operatorname{diag}(\mathbf{x})$ & & \\
\hline 9221 & 0 & 0 \\
0 & $1 \mathrm{E}+05$ & 0 \\
0 & 0 & 29492
\end{tabular}

\begin{tabular}{ccc}
$\mathbf{A}^{*}=\operatorname{diag}(\mathbf{x})^{-1} \mathbf{A} \operatorname{diag}(\mathbf{x})$ \\
\hline 0.113 & 0.000 & 0.000 \\
0.001 & 0.062 & 0.014 \\
0.009 & 0.006 & 0.062
\end{tabular}

Figure A-2. Deriving the inoperability model, $\mathbf{A}^{*}$

The derived inoperability I-O model in equations A6 and A7 shows the interdependence of the sectors upon each other:

or, solving equation A6 for $\mathbf{q}$ gives:

$$
\mathbf{q}=\mathbf{A}^{*} \mathbf{q}+\mathbf{c}^{*}
$$

$$
\mathbf{q}=\left(\mathbf{I}-\mathbf{A}^{*}\right)^{-1} \mathbf{c}^{*}
$$

where: $\mathbf{q}$ is a demand-based inoperability, representing $\%$ disrupted production

I is an identity matrix,

$\mathbf{A}^{*}$ is an interdependency matrix (derived from $\mathbf{A}$ above), multipliers, $\mathbf{c}^{*}$ is a perturbation vector, a percentage disruption

\begin{tabular}{|c|c|c|c|c|c|c|}
\hline$\left(\mathbf{I}-\mathbf{A}^{*}\right)$ & & & $\left(\mathbf{I}-\mathbf{A}^{*}\right)^{-1}$ & & c* (selected) & $\mathbf{q}=\left(\mathbf{I}-\mathbf{A}^{*}\right)^{-1} \mathbf{c}^{*}$ \\
\hline 0.887 & 0.000 & 0.000 & 1.127 & $\overline{0}$ & $1 / 8179=1.2 \mathrm{E}-4$ & $1.378 \mathrm{E}-04$ \\
\hline $0.001^{\prime}$ & 0.938 & 0.014 & $-0.002 \quad 1.066$ & -0.016 & 0 & $-1.878 \mathrm{E}-07$ \\
\hline 0.009 & 0.006 & 0.938 & $-0.010-0.007$ & 1.066 & 0 & $-1.257 \mathrm{E}-06$ \\
\hline
\end{tabular}

This is demonstrated below in Figure A-3 using the same example $3 \times 3$ matrix as above, as well as a sample perturbation vector, $\mathbf{c}^{*}$.

Figure A-3. Demonstrating interdependence of sectors

With this equation, knowing $\mathbf{A}^{*}$, which is derived from the given $\mathbf{A}$ matrix, a unit disruption will be inserted, specifically for the trucking sector in this study, in the $\mathbf{c}^{*}$ vector, which represents changes in truck user costs, to determine the percentage impact to the other sectors in $\mathbf{q}$. The values in $\mathbf{q}$ will be multiplied by the "normal" total production vector, $\hat{\mathbf{x}}$ to generate the value of the disrupted production. Sector disruptions will be proportional to the value of the original disruption, which is possible since the I-O model is linear; thus, the relative economic impact to a sector is based on an impact to the trucking sector (for example, a $\$ 1$ disruption to the trucking sector will disrupt $\$ .05$ of sector $\mathrm{A}, \$ .25$ of sector $\mathrm{B}$, etc.). Note, the unit disruption is not intended to represent any specific incident or congestion for any specific point; instead, it is used to show the various industrial sectors' dependence on the trucking sector for the study area. Thus, for any given incidents or congestion on specific highways in Virginia, it can be known which sectors will be most impacted by a disruption. 
However, since the I-O model is linear, these relative values can be multiplied by a specific value representing a trucking disruption event to show indirect impacts for an event.

A larger 12x12 matrix representing 12 industrial sectors is used to demonstrate this and the remaining steps of this methodology; Table A-1 shows a given Leontif coefficient $\mathbf{A}$ matrix and $\hat{\mathbf{c}}$ vector and the calculated $\hat{\mathbf{x}}$ from equation 1 . Table A-2 shows the results of transforming the A matrix, establishing a perturbation $\mathbf{c}^{*}$ vector, and running equation A6.

Table A-1. Example Leontif coefficient (A) matrix, $\hat{\mathbf{c}}$ vector, and calculated $\hat{\mathbf{x}}$ vector

\begin{tabular}{|c|c|c|c|c|c|c|c|c|c|c|c|c|c|c|}
\hline \multicolumn{13}{|c|}{$\mathbf{A}$ (multipliers) } & \multirow{2}{*}{$\begin{array}{l}\hat{\mathbf{c}} \\
(\mathrm{Mil} \$)\end{array}$} & \multirow{2}{*}{$\begin{array}{l}\hat{\mathbf{x}} \\
(\text { Mil \$) }\end{array}$} \\
\hline Sector & 1 & 2 & 3 & 4 & 5 & 6 & 7 & 8 & 9 & 10 & 11 & 12 & & \\
\hline 1 & 0.113 & 0.000 & 0.000 & 0.000 & 0.000 & 0.000 & 0.000 & 0.092 & \begin{tabular}{|l|}
0.000 \\
\end{tabular} & 0.000 & 0.000 & 0.000 & 8179 & 26900 \\
\hline 2 & 0.017 & 0.062 & 0.051 & 0.046 & 0.021 & 0.093 & 0.001 & 0.012 & 0.005 & 0.001 & 0.003 & 0.002 & 101947 & 132275 \\
\hline 3 & 0.027 & 0.002 & 0.062 & 0.002 & 0.000 & 0.001 & 0.000 & 0.026 & 0.001 & 0.000 & 0.000 & 0.001 & 27243 & 35584 \\
\hline 4 & 0.011 & 0.004 & 0.003 & 0.157 & 0.004 & 0.003 & 0.001 & 0.004 & \begin{tabular}{|l|}
0.011 \\
\end{tabular} & 0.011 & 0.010 & 0.010 & 123980 & 157097 \\
\hline 5 & 0.005 & 0.004 & 0.001 & 0.001 & 0.125 & 0.002 & 0.000 & 0.004 & 0.000 & 0.000 & 0.000 & 0.000 & 26494 & 32446 \\
\hline 6 & 0.003 & 0.000 & 0.005 & 0.004 & 0.002 & 0.061 & 0.003 & 0.002 & \begin{tabular}{|l|}
0.002 \\
\end{tabular} & 0.004 & 0.004 & 0.003 & 84463 & 94137 \\
\hline 7 & 0.001 & 0.001 & 0.001 & 0.013 & 0.001 & 0.013 & 0.124 & 0.002 & 0.021 & 0.009 & 0.007 & 0.004 & 150336 & 180285 \\
\hline 8 & 0.019 & 0.009 & 0.002 & 0.005 & 0.003 & 0.003 & 0.003 & 0.000 & 0.017 & 0.005 & 0.031 & 0.020 & 158895 & 170903 \\
\hline 9 & 0.000 & 0.000 & 0.000 & 0.000 & 0.000 & 0.000 & 0.000 & 0.000 & \begin{tabular}{|l|}
0.000 \\
\end{tabular} & 0.000 & 0.000 & 0.000 & 3606 & 3684 \\
\hline 10 & 0.007 & 0.007 & 0.021 & 0.007 & 0.015 & 0.007 & 0.009 & 0.012 & \begin{tabular}{|l|}
0.012 \\
\end{tabular} & 0.047 & 0.032 & 0.008 & 244304 & 268588 \\
\hline 11 & 0.003 & 0.001 & 0.003 & 0.004 & 0.001 & 0.003 & 0.003 & 0.002 & 0.002 & 0.003 & 0.004 & 0.003 & 48363 & 52395 \\
\hline 12 & 0.004 & 0.002 & 0.005 & 0.005 & 0.002 & 0.019 & 0.004 & 0.003 & \begin{tabular}{|l|}
0.003 \\
\end{tabular} & 0.004 & 0.006 & 0.01 & 270999 & 280740 \\
\hline
\end{tabular}

From Santos, 2003

Table A-2. Normal and Reduced Industrial Output by a unit reduction to the $6^{\text {th }}$ industrial sector using Inoperability I-O Model

\begin{tabular}{|c|c|c|c|c|}
\hline \multirow{2}{*}{$\begin{array}{l}\text { Industrial } \\
\text { Sector }\end{array}$} & $\begin{array}{c}\text { Normal } \\
\text { Output }\end{array}$ & $\begin{array}{l}\text { Perturbation } \\
\text { Vector }\end{array}$ & $\begin{array}{c}\% \\
\text { Affected } \\
\end{array}$ & $\begin{array}{c}\text { Reduced } \\
\text { Output }\end{array}$ \\
\hline & $\begin{array}{c}\hat{\hat{\mathbf{x}}} \\
\text { (Millions \$) }\end{array}$ & $\begin{array}{l}\mathbf{c}^{*} \\
(\%)\end{array}$ & $\underset{(\%)}{\mathbf{q}}$ & $\stackrel{\hat{\mathbf{x}} \mathbf{q}}{\text { (Millions \$) }}$ \\
\hline 1 & 26900 & 0 & $1.74 \mathrm{E}-06$ & 0.0005 \\
\hline 2 & 132275 & 0 & 8.02E-05 & 0.1061 \\
\hline 3 & 35584 & 0 & $2.92 \mathrm{E}-06$ & 0.0010 \\
\hline 4 & 157097 & 0 & $2.89 \mathrm{E}-06$ & 0.0045 \\
\hline 5 & 32446 & 0 & $7.70 \mathrm{E}-06$ & 0.0025 \\
\hline $6^{*}$ & 94137 & $1 / 94137$ & 1.13E-03 & 1.0657 \\
\hline 7 & 180285 & 0 & 8.87E-06 & 0.0160 \\
\hline 8 & 170903 & 0 & $2.65 \mathrm{E}-06$ & 0.0045 \\
\hline 99 & 3684 & 0 & $3.29 \mathrm{E}-06$ & 0.0001 \\
\hline 10 & 268588 & 0 & $3.21 \mathrm{E}-06$ & 0.0086 \\
\hline 11 & 52395 & 0 & $7.01 \mathrm{E}-06$ & 0.0037 \\
\hline 12 & 280740 & 0 & 7.60E-06 & 0.0213 \\
\hline
\end{tabular}

*disrupted sector (trucking sector), with unit reduction to output 
2. Identify freight flows from the transportation-dependent sectors throughout the study area. Again, the study area for this demonstration is the state of Virginia. The Freight Analysis Framework (FAF) analysis regions for this area are obtained. External regions would typically be strategically aggregated for inclusion during this step (e.g., if Virginia is the study area, all FAF regions in New England might be grouped, since their freight flows would likely be entering the study area on the same highways, in this case I-81 or I-95). For the purpose of this demonstration, however, only intrastate regional flows are considered. The FAF contains Commodity Flow Survey data, and these commodities will be matched to BEA commodities in the input-output model (see Table A-3) using resources such as NCHRP Report 606 (Cambridge Systematics, et al., 2008). Now, the sectors impacted by the transportation disruption in step 1 will be selected from the FAF by mode (truck), regions selected, and commodities selected.

Table A-3. Matched sectors and economic rank given in inoperability I-O example

\begin{tabular}{|c|c|c|c|}
\hline \begin{tabular}{c|} 
Example \\
Model \\
Sector
\end{tabular} & $\begin{array}{c}\text { Relative } \\
\text { Economic } \\
\text { Impact }\end{array}$ & $\begin{array}{c}\text { Assumed Bureau of Economic } \\
\text { Analysis Sectors }\end{array}$ & Assigned Commodity Flow Sectors \\
\hline 6 & 1.0657 & Trucking & Truck Transportation \\
\hline 2 & 0.1061 & Food Manufacturing & Milled Grains AND Other Foodstuffs \\
\hline 12 & 0.0213 & $\begin{array}{l}\text { Basic Chemical Manufacturing } \\
\text { Petroleum and Coal Products }\end{array}$ & Basic Chemicals \\
\hline 7 & 0.0160 & Manufacturing & Fuel Oils AND Gasoline \\
\hline 10 & 0.0086 & Agricultural Chemical Production & Fertilizer \\
\hline 4 & 0.0045 & $\begin{array}{l}\text { Animal Production } \\
\text { Pharmaceutical \& Medical }\end{array}$ & Meat/Seafood \\
\hline 8 & 0.0045 & Manufacturing & Pharmaceuticals \\
\hline 11 & 0.0037 & Apparel Product Manufacturing & Textiles/Leather \\
\hline 5 & 0.0025 & Forestry \& Logging & Logs \\
\hline 3 & 0.0010 & Plastics \& Rubber Manufacturing & Plastics/Rubber \\
\hline 1 & 0.0005 & Electrical Equipment Manufacturing & Electronics \\
\hline 9 & 0.0001 & Crop Production & Cereal Grains AND Other Ag. Prod. \\
\hline
\end{tabular}

3. Create an Origin-Destination Model of the study area to generate a metric of economic importance. First, nodes will be selected throughout the study area for various points such as population centers, seaports, and industrial areas (see, for example, selected nodes for the model example denoted as red points in Figure A-4). Again, by this step, external stations for origins and destinations outside of the study area would be strategically created for freight flows entering and exiting the area. The regional flows from the FAF (see Table A-4) will be scaled for their relative economic impact and summed (see Table A-5), and then disaggregated amongst the selected nodes (see Tables A-6, A-7). For assistance with this, NCHRP 606 (Cambridge Systematics, et al., 2008) provides guidance for freight productions and attractions using employment and population data for a region. The FAF highway network will be obtained, and routes connecting these nodes will be identified (see Figure A-5). The scaled commodity flows from step two will be assigned to the network using impedances, such as speed, route quality and route length (see Table 
A-8); known 2007 AADTT for the network will assist with appropriate route assignment. Summing the resulting flows for each link will give a metric of economic importance (see Figure A-5). Beyond freight tonnage or value of freight, this metric emphasizes corridors used by industrial sectors whose production is most affected by a transportation disruption and whose output is most critical to the region's economy.

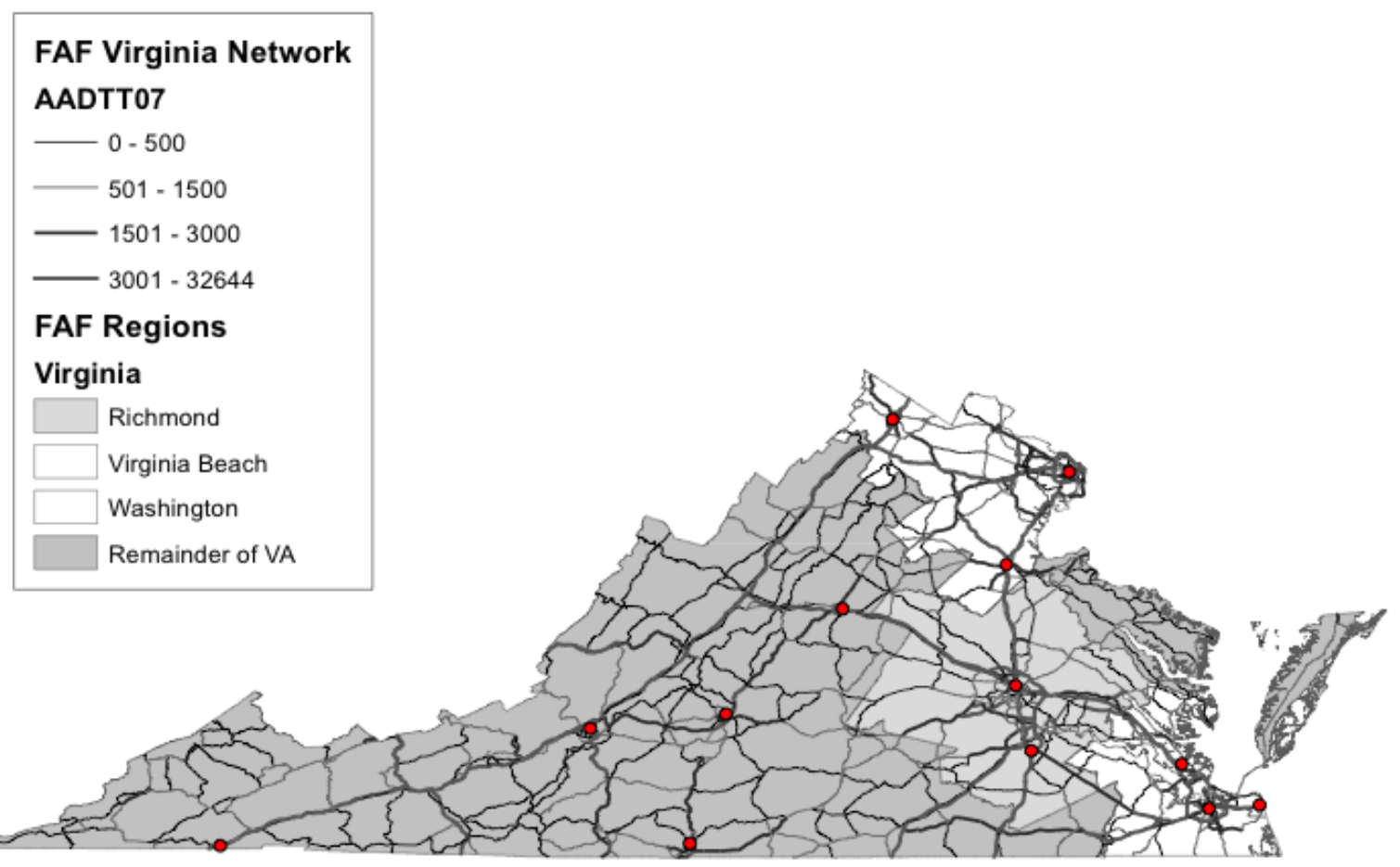

Figure A-4. Freight Analysis Framework - Virginia regions, network and sample nodes 
Table A-4. Freight truck flows in kilotons for industrial sectors 1-5, 7-12

\begin{tabular}{|c|c|c|c|c|c|c|c|c|c|c|c|c|c|}
\hline Origin & D & $\begin{array}{l}\text { Total } \\
\text { Kton }\end{array}$ & 1 & 2 & 3 & 4 & 5 & 7 & 8 & 9 & 10 & 11 & 12 \\
\hline $\begin{array}{l}\text { Norfolk VA-NC MSA } \\
\text { VA Part) }\end{array}$ & ia & 199 & 1 & 32 & 2 & 3 & 0 & 0 & 0 & 146 & 14 & 0 & 0 \\
\hline & VA MSA & 1326 & 2 & 800 & 49 & 19 & 0 & 180 & 10 & 248 & 5 & 9 & 4 \\
\hline A-NC MSA & $\begin{array}{l}\text { C-MD- } \\
\text { (VA Part) }\end{array}$ & 113 & 2 & 5 & 2 & 17 & 0 & 36 & 0 & 50 & 2 & 0 & 0 \\
\hline Rema & & 608 & 16 & 184 & 2 & 57 & 75 & 157 & 0 & 112 & 2 & 3 & 0 \\
\hline Remainder of & Richmond VA MSA & 1949 & 6 & 417 & 9 & 24 & 766 & 523 & 1 & 192 & 4 & 6 & 0 \\
\hline Reme & & 1006 & 16 & 221 & 5 & 15 & 4 & 611 & 0 & 129 & 2 & 4 & 0 \\
\hline Richmond VA MSA & -NC MSA & 648 & 4 & 267 & 21 & 2 & 55 & 124 & 1 & 111 & 29 & 4 & 30 \\
\hline Richn & Remainder of Viroinia & 577 & 5 & 104 & 26 & 13 & 200 & 30 & 2 & 111 & 61 & 3 & 23 \\
\hline Rich & $\begin{array}{l}\text { DC-MD- } \\
\text { (VA Part) }\end{array}$ & 728 & 4 & 112 & 11 & 18 & 1 & 164 & 16 & 388 & 1 & 1 & 13 \\
\hline $\begin{array}{l}\text { (D- } \\
\text { Part) }\end{array}$ & $\begin{array}{l}\text { Norfolk VA-NC MSA } \\
\text { (VA Part) }\end{array}$ & 28 & 3 & 4 & 2 & 0 & 0 & 0 & 0 & 4 & 0 & 16 & 0 \\
\hline $\begin{array}{l}\text { Washington I } \\
\text { VA-WV CS }\end{array}$ & & 134 & 3 & 64 & 19 & 1 & 0 & 10 & 0 & 29 & 3 & 2 & 3 \\
\hline Washington & & 509 & 3 & 260 & 14 & 3 & 2 & 80 & 0 & 137 & 0 & 7 & 2 \\
\hline $\begin{array}{l}\text { Norfolk VA-NC MSA } \\
\text { (VA Part) }\end{array}$ & t) & 4407 & 89 & 538 & 54 & 247 & 234 & 1978 & 10 & 881 & 300 & 66 & 11 \\
\hline Remainder of Virginia & Remainder of Virginia & 21866 & 68 & 5712 & 74 & 747 & 11817 & 1604 & 12 & 1345 & 383 & 84 & 20 \\
\hline & & 8849 & 64 & 667 & 125 & 80 & 4917 & 1792 & 13 & 609 & 217 & 79 & 284 \\
\hline $\begin{array}{l}\text { Washington DC-MD- } \\
\text { VA-WV CSA (VA Part) }\end{array}$ & \begin{tabular}{|l} 
Washington DC-MD- \\
VA-WV CSA (VA Part)
\end{tabular} & 6872 & 112 & 613 & 69 & 133 & 423 & 3520 & 18 & 1309 & 483 & 163 & 30 \\
\hline & TOTAL: & 49820 & 395 & 10000 & 483 & 1380 & 18494 & 10809 & 83 & 5800 & 1508 & 446 & 421 \\
\hline
\end{tabular}

Source: FHWA Freight Analysis Framework

Gray rows are intraregional flows, which were removed from analysis for this example

Table A-5. Aggregated FAF O-D Table after scaling

\begin{tabular}{|l|l|c|}
\hline \multicolumn{1}{|c|}{ Origin } & \multicolumn{1}{c|}{ Destination } & $\begin{array}{c}\text { Economic } \\
\text { Importance }\end{array}$ \\
\hline Norfolk VA-NC MSA (VA Part) & Remainder of Virginia & $\ldots$ \\
\hline Norfolk VA-NC MSA (VA Part) & Richmond VA MSA & $\ldots$ \\
\hline Norfolk VA-NC MSA (VA Part) & Washington DC-MD-VA-WV CSA (VA Part) & $\ldots$ \\
\hline Remainder of Virginia & Norfolk VA-NC MSA (VA Part) & $\ldots$ \\
\hline$\ldots$ & $\ldots$ & $\ldots$ \\
\hline
\end{tabular}

*Note: no intraregional flows for this example 
Table A-6. Disaggregated O-D Table by Selected Nodes

\begin{tabular}{|l|l|r|}
\hline \multicolumn{1}{|c}{ Origin } & \multicolumn{1}{c|}{ Destination } & $\begin{array}{c}\text { Economic } \\
\text { Importance }\end{array}$ \\
\hline Virginia Beach & Bristol & 0.08 \\
\cline { 2 - 3 } & Danville & 0.21 \\
\cline { 2 - 3 } & Roanoke & 0.44 \\
\cline { 2 - 3 } & Lynchburg & 0.34 \\
\cline { 2 - 3 } & Charlottesville & 0.20 \\
\cline { 2 - 3 } & Richmond & 27.16 \\
\cline { 2 - 3 } & Petersburg & 4.43 \\
\cline { 2 - 3 } & Alexandria/Arl. & 0.36 \\
\cline { 2 - 3 } & Winchester & 0.03 \\
\cline { 2 - 3 } & Fredericksburg & 0.02 \\
\hline Norfolk/Chesapeake & Bristol & 0.09 \\
\cline { 2 - 3 } & Danville & 0.22 \\
\hline \multirow{2}{*}{} & $\ldots$ & $\ldots$ \\
\hline
\end{tabular}

Table A-7. Economic Value of Links between Selected Nodes

\begin{tabular}{|c|c|c|c|c|c|c|c|c|c|c|}
\hline Link & $\begin{array}{l}\text { Virginia } \\
\text { Beach } \\
\end{array}$ & \begin{tabular}{|l|} 
Norfolk/ \\
Chesapeake
\end{tabular} & \begin{tabular}{|l|} 
Hampton/ \\
Newport News \\
\end{tabular} & Bristol & Danville & Roanoke & Lynchburg & C-ville & Richmond & Petersburg \\
\hline Bristol & 0.61 & 0.63 & 0.45 & $\mathrm{x}$ & $\mathrm{x}$ & $\mathrm{x}$ & $\mathrm{x}$ & $\mathrm{x}$ & & \\
\hline Danville & 1.55 & 1.62 & 1.16 & $\mathrm{x}$ & $\mathrm{x}$ & $\mathrm{x}$ & $\mathrm{x}$ & $\mathrm{x}$ & & \\
\hline Roanoke & 3.23 & 3.38 & 2.42 & $\mathrm{x}$ & $\mathrm{x}$ & $\mathrm{x}$ & $\mathrm{x}$ & $\mathrm{x}$ & & \\
\hline Lynchburg & 2.52 & 2.64 & 1.89 & $\mathrm{x}$ & $\mathrm{x}$ & $\mathrm{x}$ & $\mathrm{x}$ & $\mathrm{x}$ & & \\
\hline C-ville & 1.44 & 1.51 & 1.08 & $\mathrm{x}$ & $\mathrm{x}$ & $\mathrm{x}$ & $\mathrm{x}$ & $\mathrm{x}$ & & \\
\hline Richmond & 36.83 & 38.46 & 27.52 & 3.78 & 9.70 & 20.18 & 15.76 & 9.01 & $\mathrm{x}$ & $\mathrm{x}$ \\
\hline Petersburg & 6.00 & 6.27 & 4.48 & 0.62 & 1.58 & 3.29 & 2.57 & 1.47 & $\mathrm{x}$ & $\mathrm{x}$ \\
\hline Alexandria/Arl & 0.51 & 0.53 & 0.38 & 2.31 & 5.91 & 12.30 & 9.61 & 5.49 & 33.24 & 5.42 \\
\hline Winchester & 0.04 & 0.04 & 0.03 & 0.17 & 0.43 & 0.89 & 0.70 & 0.40 & 2.41 & 0.39 \\
\hline Fredericksburg & 0.03 & 0.03 & 0.02 & 0.15 & 0.38 & 0.79 & 0.62 & 0.35 & 2.14 & 0.35 \\
\hline
\end{tabular}

Table A-8. Example of Link for Route Assignment

\begin{tabular}{|c|c|c|c|c|c|c|c|}
\hline Link & Routes & Miles & Speed & AADTT & Iteration 1 & Iteration 2 & Assignment \\
\hline \multirow{2}{*}{$\begin{array}{l}\text { Bristol - } \\
\text { VA Beach }\end{array}$} & US 58 & 413 & 50 & 500 & 0.06 & 0.06 & 0.03 \\
\hline & $\mathrm{I}-81, \mathrm{US} 460$ & 411 & 55 & 1500 & 0.20 & 0.18 & 0.11 \\
\hline 0.61 & $\mathrm{I}-81, \mathrm{I}-64$ & 429 & 65 & 5500 & 0.82 & 0.76 & 0.46 \\
\hline & & & & & 1.08 & 1.00 & \\
\hline
\end{tabular}




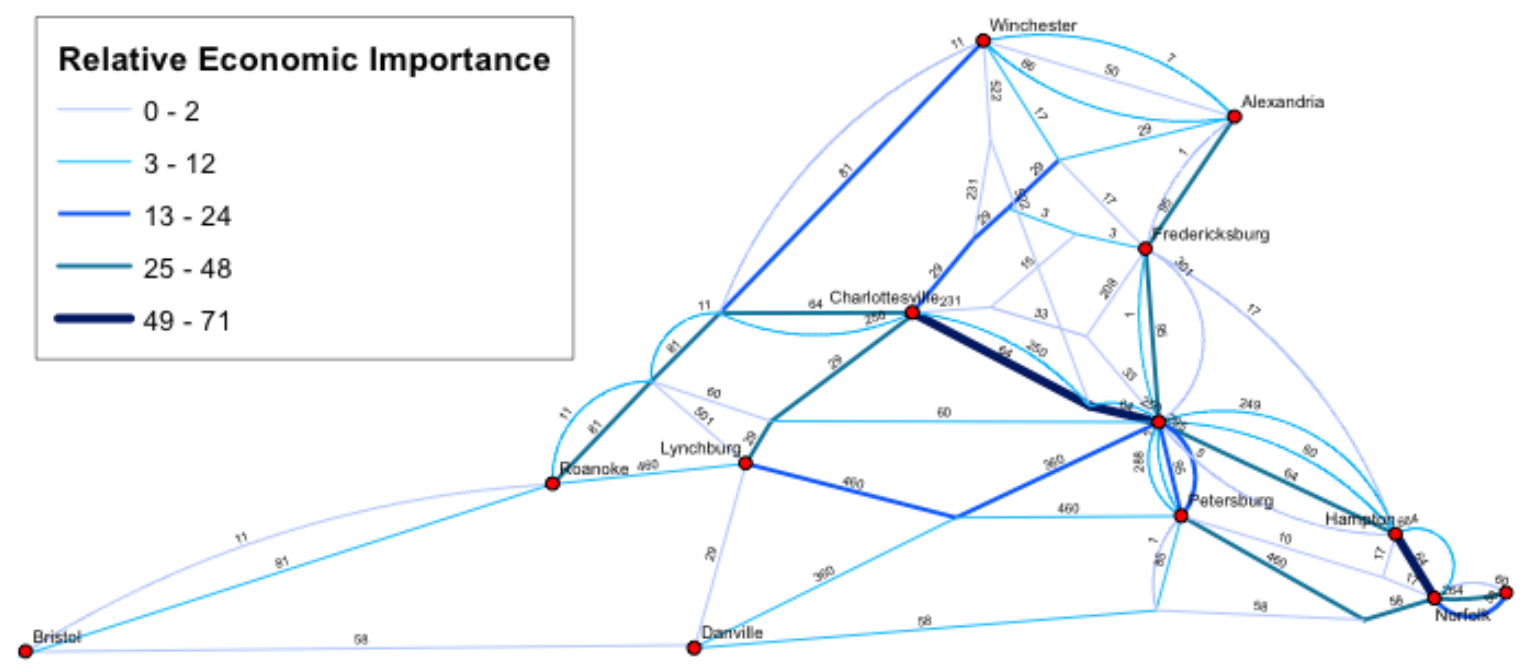

Figure A-5. Relative Economic Importance of Virginia Freight Highways

4. Identify and prioritize infrastructure needs. Select an existing asset management system. Obtain data from the National Bridge Inventory Analysis System, Highway Performance Management System, FAF, etc. and apply the performance measures from the asset management system to identify bridges and pavements, safety, and mobility needs along corridors.

a. Find the National Bridge Inventory Analysis System "detour length" value to assign to each route in the network. Calculate additional truck user costs associated with 1) detour length associated with a closure or incident on each link for a given period of time and 2) congestion for a given period of time. Texas Transportation Institute's Urban Mobility Report (Schrank et al., 2010) estimates a trucking value of $\$ 105.67$ per hour, including fuel costs. Based on AADTT for each link, the length and capacity of a detour route in the event of a closure, an estimate of excess trucking costs can be calculated for each link (see Figure A-6), which would provide a second metric of economic importance: the higher the value, the greater impact inflicted upon the trucking sector.

$b$. Another measure of economic importance will be developed using the I-O model from step 1 , commodity assignments from step 3 , and procedure developed by Mahady and Lahr (2008). In the Mahady and Lahr application, the production function of the I-O matrix (A matrix) for the trucking sector is adjusted by reducing (or increasing) the trucking sector inputs in relevant industrial sectors for a given route based on the commodity route assignment, and the matrix is renormalized. Using this modified production (A) matrix for an I-O model, given calculated excess user costs per truck by sector, a third measure of economic importance can be generated for each link showing indirect economic impacts of closures to specific route links by sector; this value translates to a measure of productivity either increased or decreased due to costs of inefficiencies (congestion or closures) in the transportation network. Use the direct and indirect economic metrics and that from step 3 to prioritize infrastructure needs that were identified earlier in this step. 


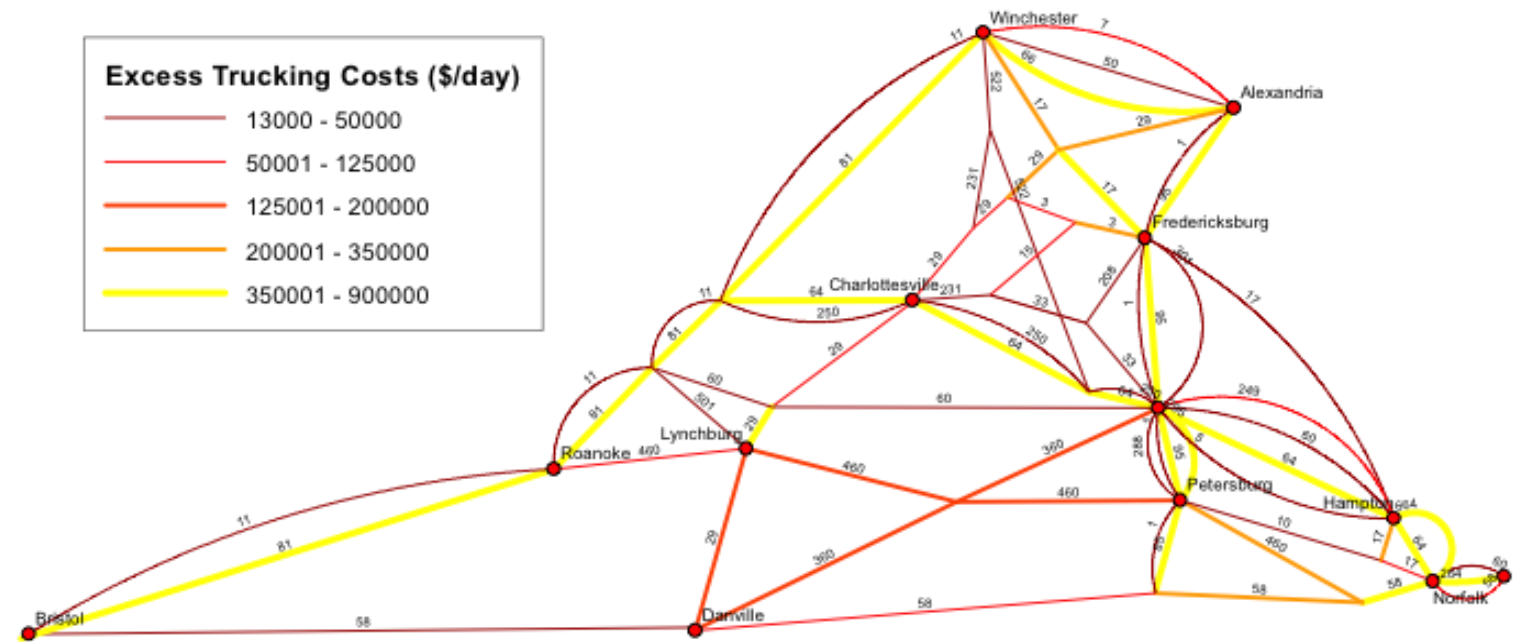

Figure A-6. Estimate of Excess Trucking Costs per day based on AADTT, Detour Length $\&$ Relative Capacity of Detour 


\section{APPENDIX B - INPUT-OUTPUT DATA TABLES USED IN CONCEPT DEMONSTRATION}

TABLE B-1. BEA MAKE TABLE: THE MAKE OF COMMODITIES BY INDUSTRIES, ANNUAL I-O ACCOUNTS, 2007

TABLE B-3. NORMALIZED MAKE TABLE

TABLE B-4. NORMALIZED USE TABLE

TABLE B-5. INPUT-OUTPUT MODEL: LEONTIF INDUSTRY-BY-INDUSTRY TECHNICAL COEFFICIENT MATRIX, A

TABLE B-6. INPUT-OUTPUT MODEL VECTORS AX, X, AND C

TABLE B-7. INOPERABILITY INPUT-OUTPUT MODEL A* MATRIX

TABLE B-8. INOPERABILITY INPUT-OUTPUT MODEL RESULTS: PERTURBATION VECTOR, $\mathbf{C}^{*}$; PERCENT DISRUPTION VECTOR, Q; AND ASSOCIATED COSTS ASSOCIATED WITH THE GIVEN DISRUPTION, \$ ECONOMIC ANALYSIS (BEA) INDUSTRIES; SCTG COMMODITIES IN BOLD ARE USED IN CONCEPT DEMONSTRATION, BEA INDUSTRIES WITH ITALICS WERE NOT MATCHED IN FAF DOCUMENTATION 
Table B-1. BEA Make Table: The Make of Commodities by Industries, Annual I-O Accounts, 2007 (page 1 of 3)

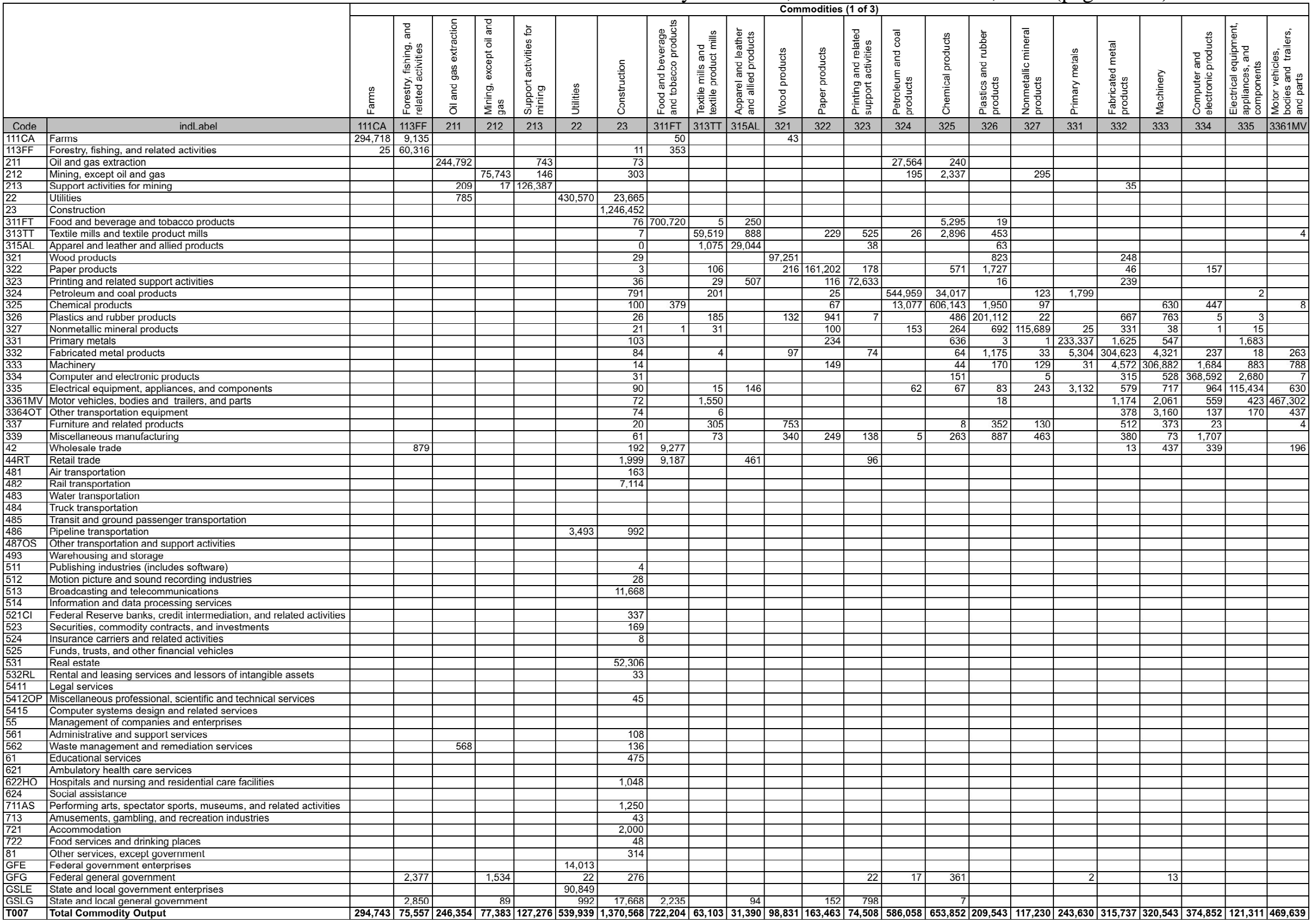


BEA Make Table: The Make of Commodities by Industries, Annual I-O Accounts, 2007 continued (page 2 of 3)

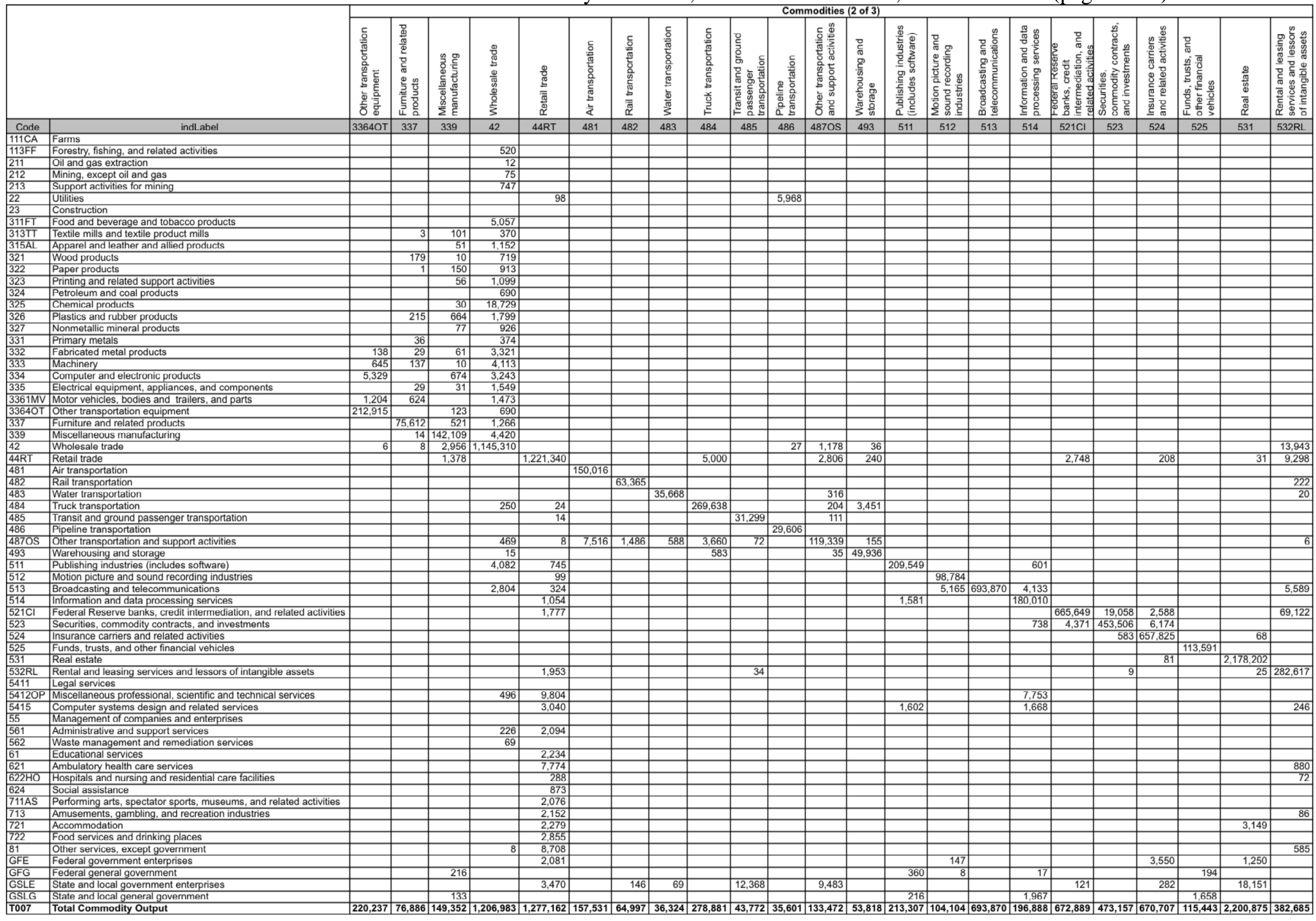


BEA Make Table: The Make of Commodities by Industries, Annual I-O Accounts, 2007 continued (page 3 of 3)

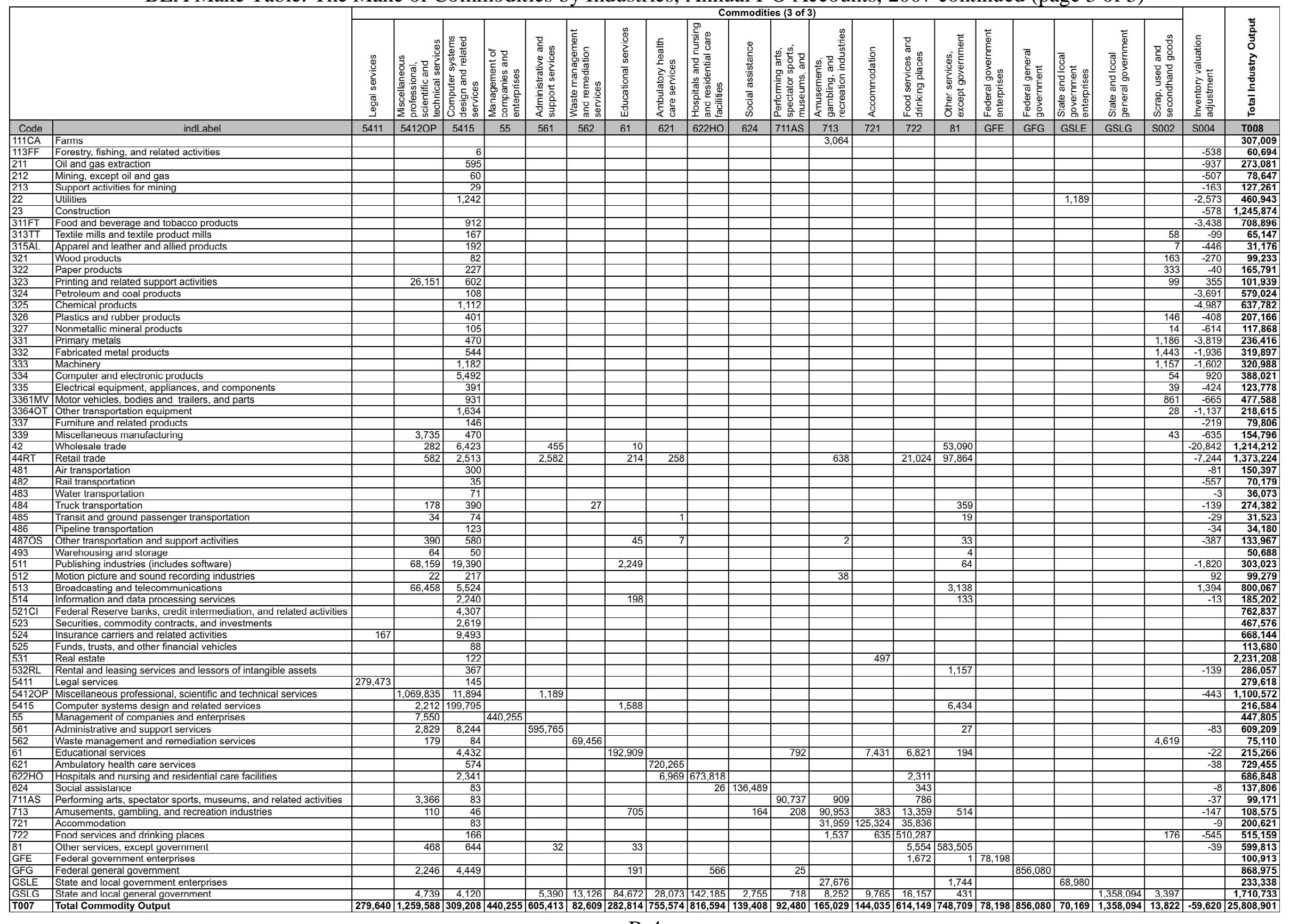


Table B-2. BEA Use Table: The Use of Commodities by Industries, Annual I-O Accounts, 2007 (page 1 of 3)

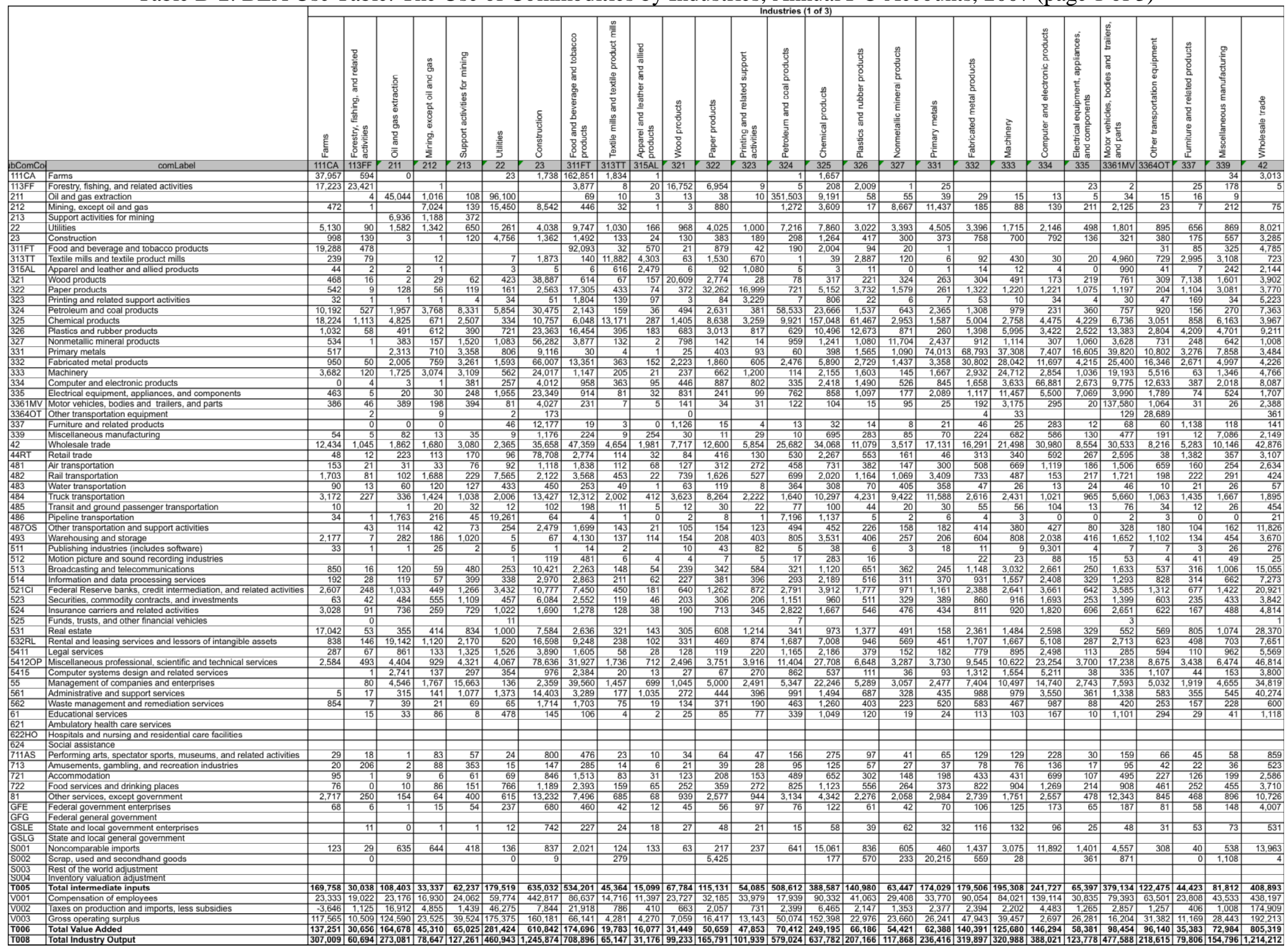


BEA Use Table: The Use of Commodities by Industries, Annual I-O Accounts, 2007 continued (page 2 of 3)

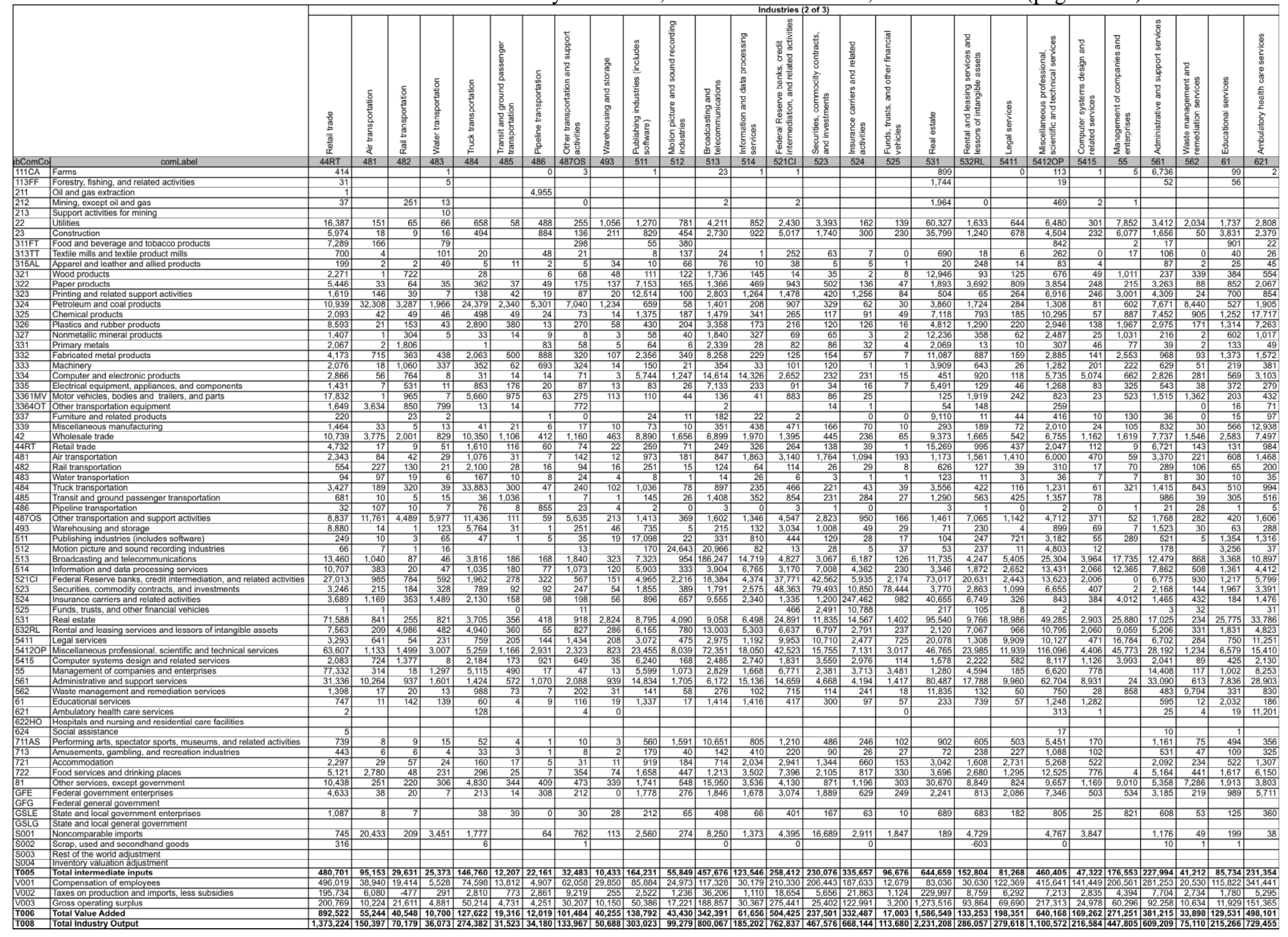


BEA Use Table: The Use of Commodities by Industries, Annual I-O Accounts, 2007 continued (page 3 of 3)

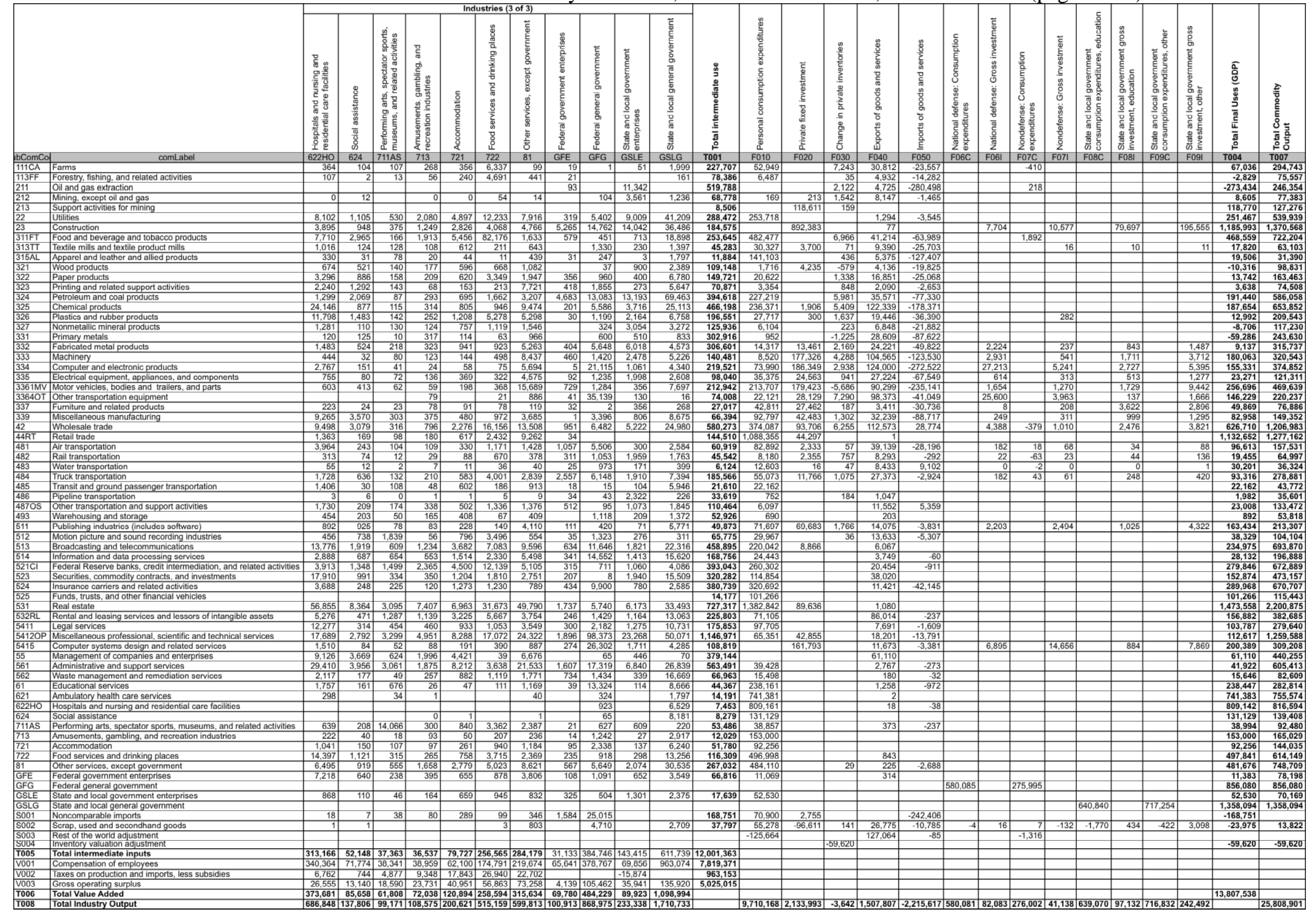


Table B-3. Normalized Make Table (page 1 of 3)

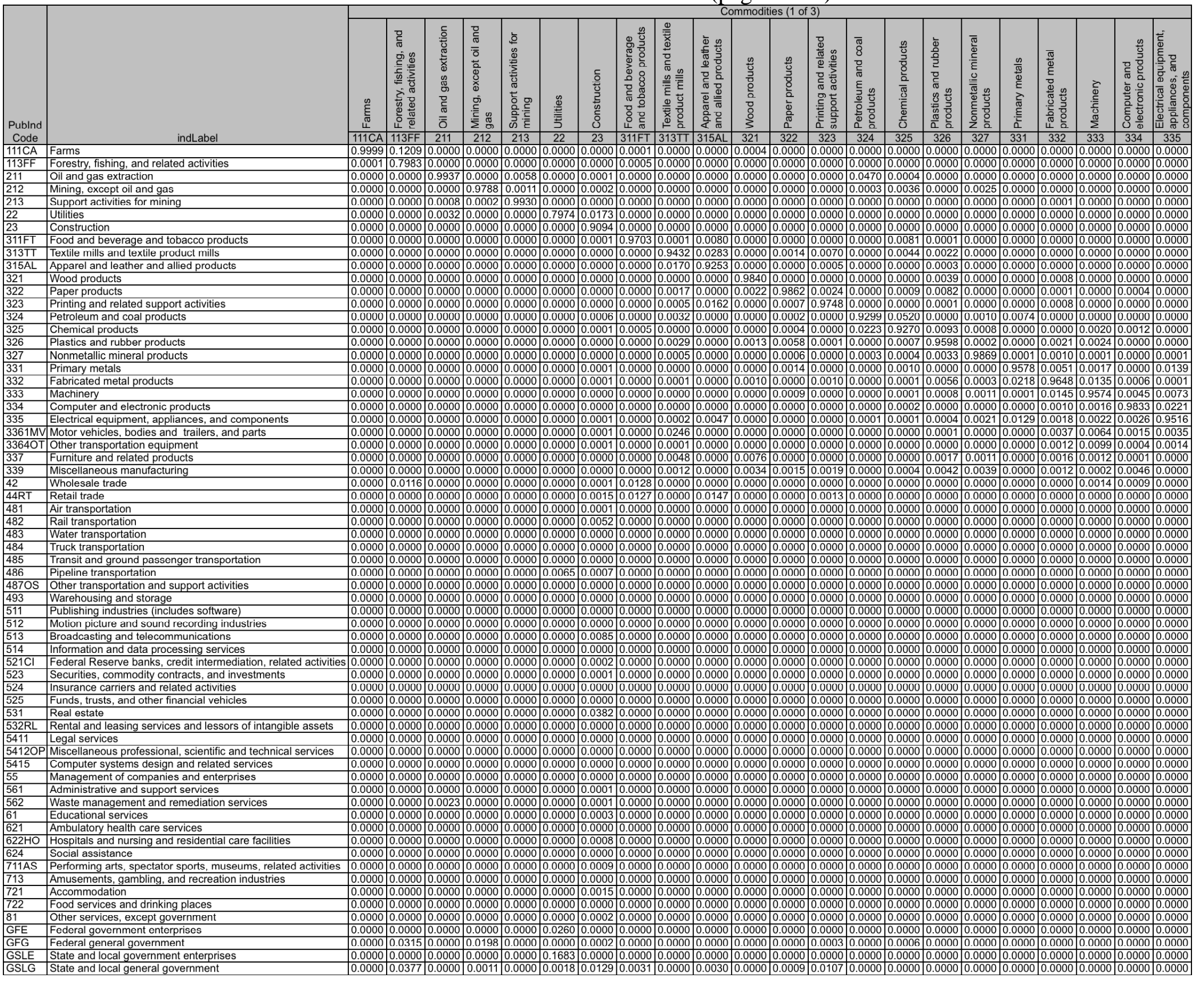


Normalized Make Table continued (page 2 of 3 )

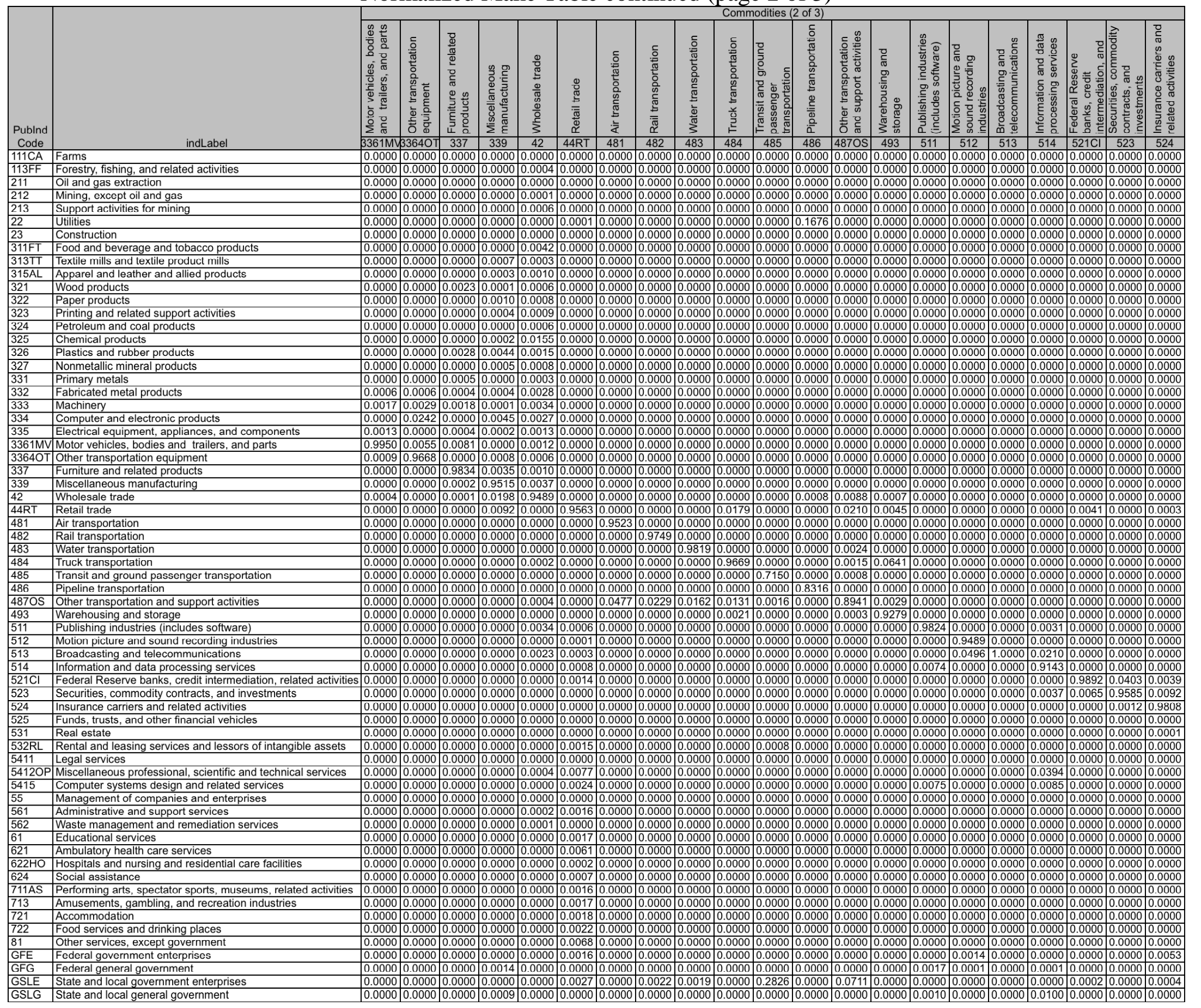

\section{B-9}


Normalized Make Table continued (page 3 of 3 )

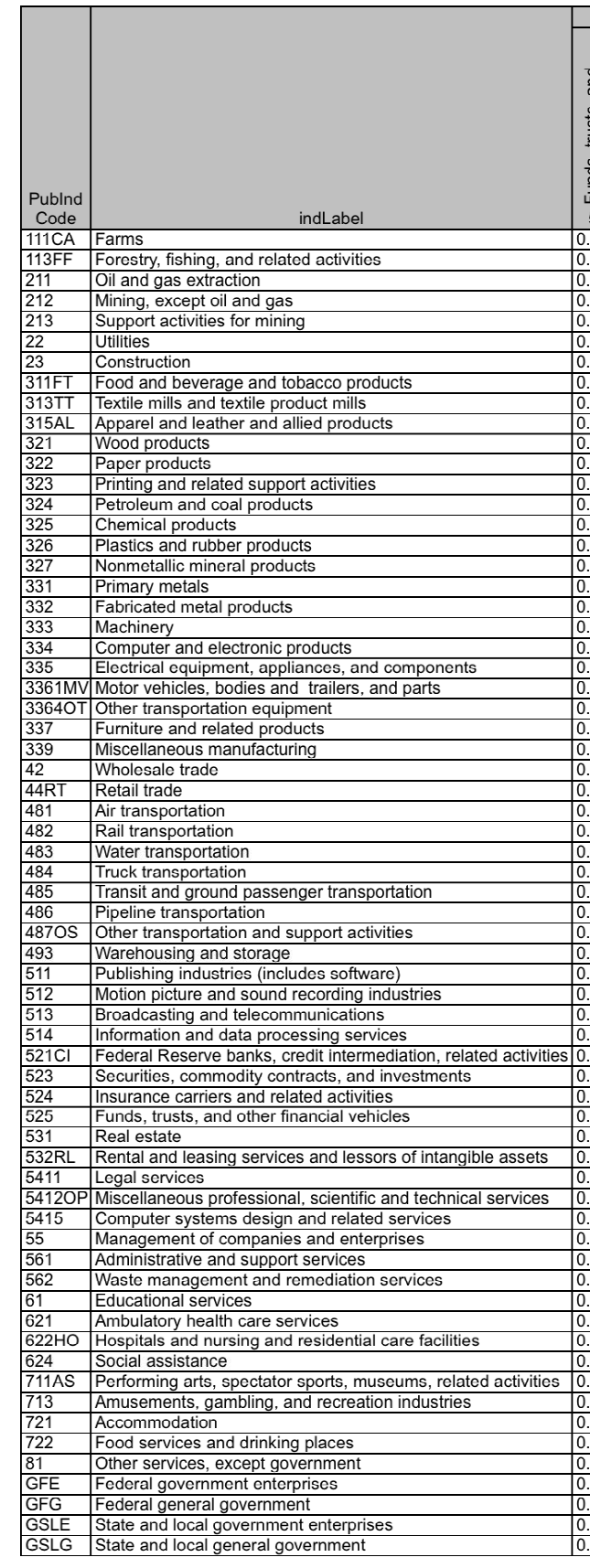

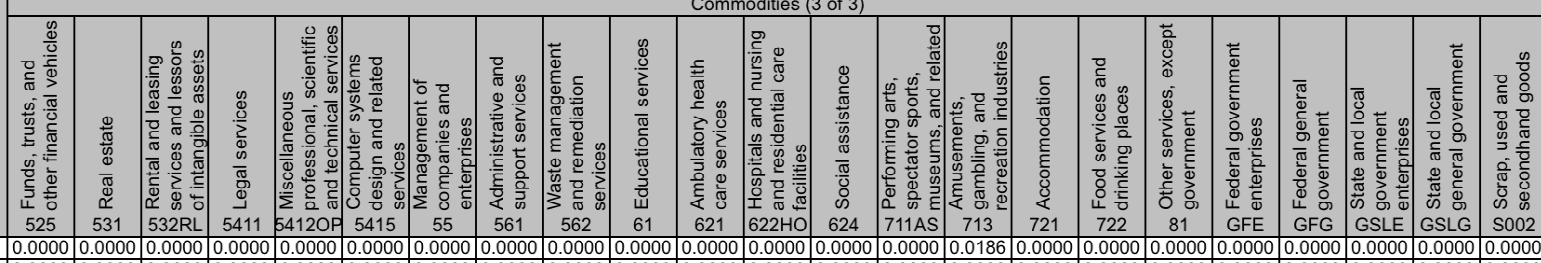

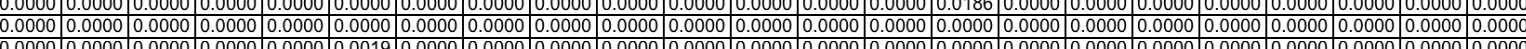

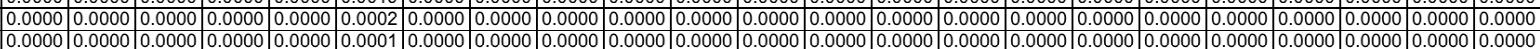

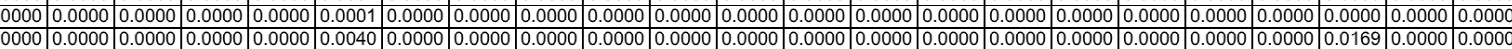

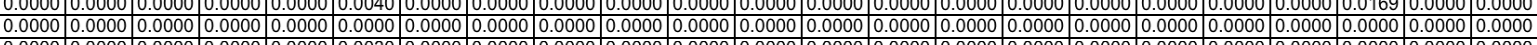

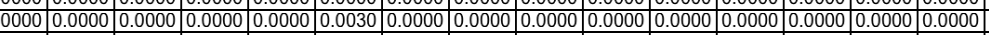

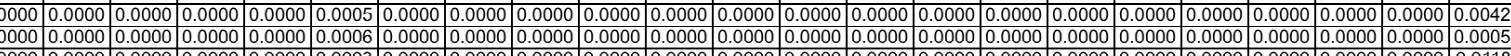

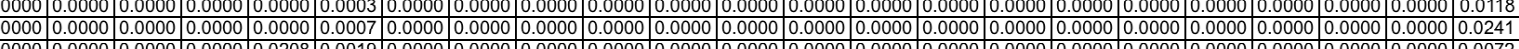

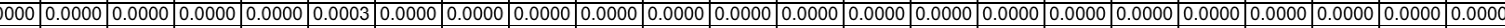

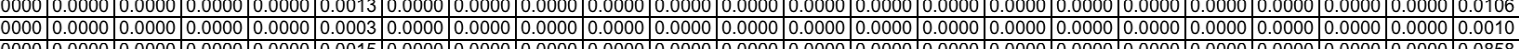

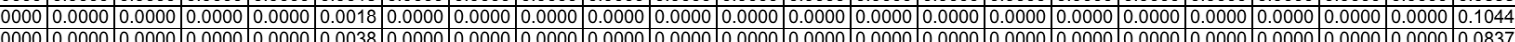

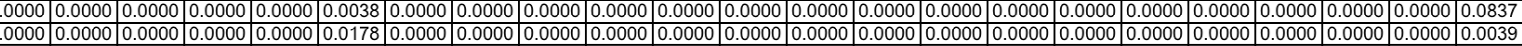

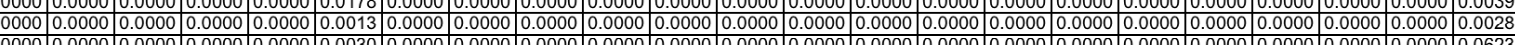

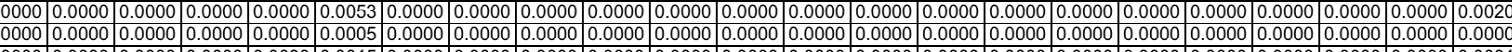

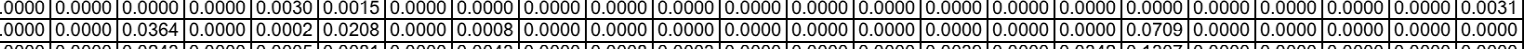

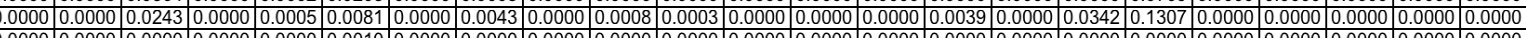

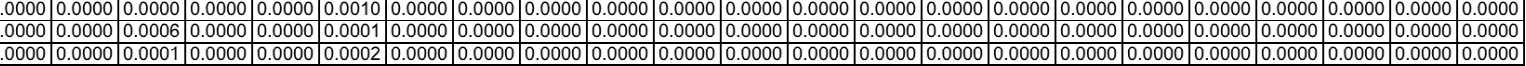

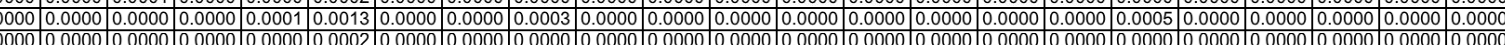

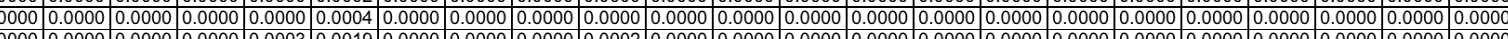

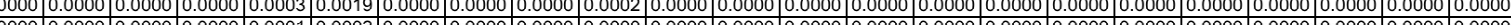

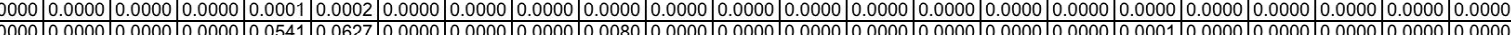

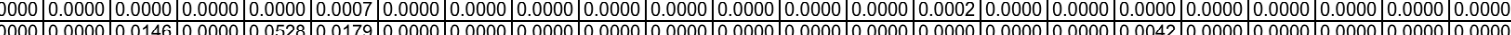

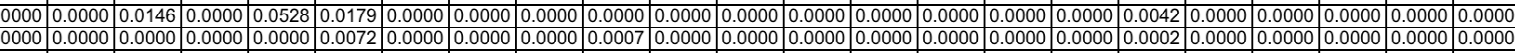

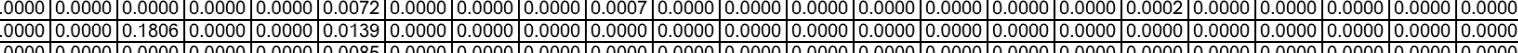

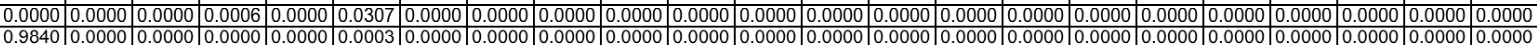

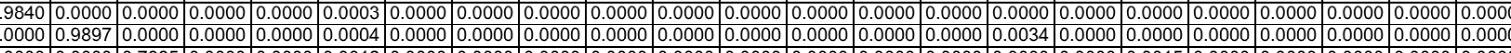

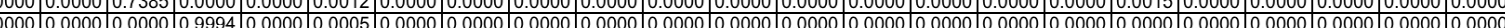

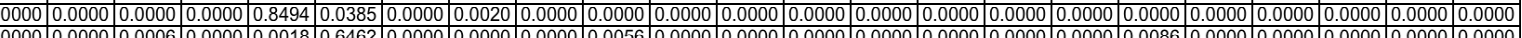

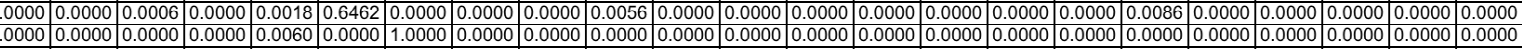

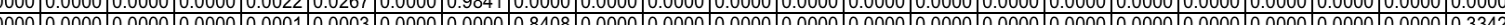

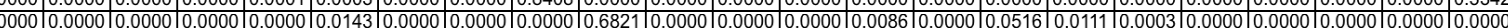

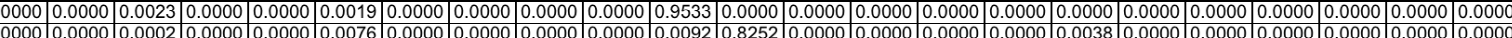

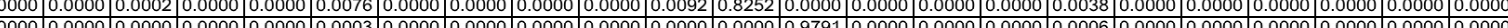

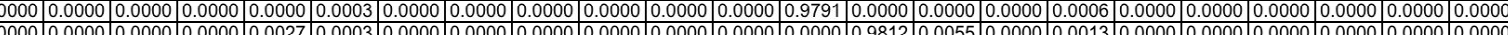

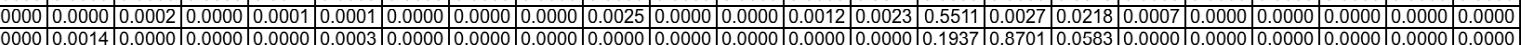

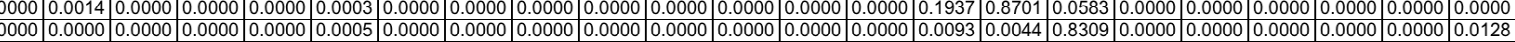

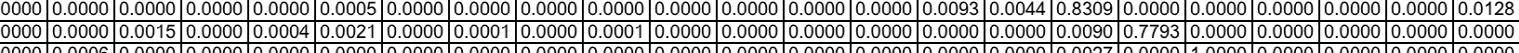

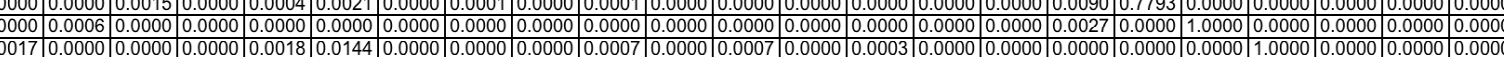

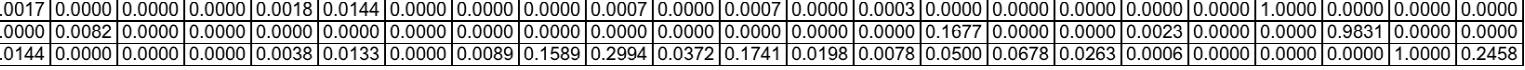


Table B-4. Normalized Use Table (page 1 of 3)

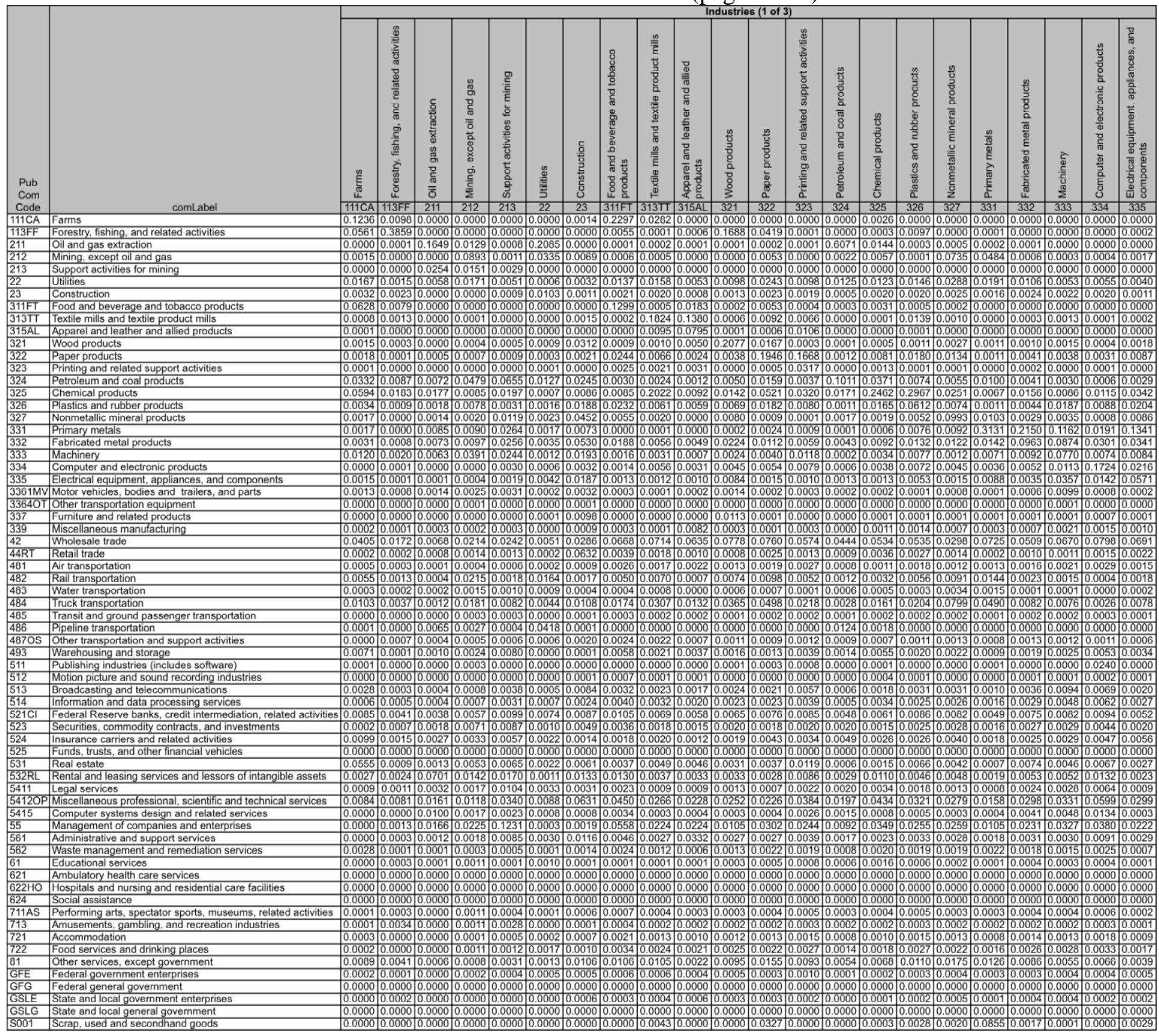


Normalized Use Table continued (page 2 of 3)

$\mathrm{Pu}$
$\mathrm{Co}$
$\mathrm{Co}$

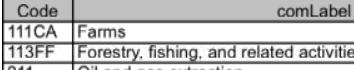

\begin{tabular}{|l|l|}
\hline 211 & Oil and gas extraction \\
\hline 212 & Mining excet \\
\hline 22 &
\end{tabular}

\begin{tabular}{|l|l|}
\hline 212 & Mining, except oil and gas \\
\hline 213 & Support activities for mining \\
\hline 22 & Utilities
\end{tabular}

\begin{tabular}{|l|l|}
\hline 23 & Construction \\
\hline 311 FT & Food and beverage and tobacco products \\
\hline $313 T$ & To
\end{tabular}

\begin{tabular}{l|l}
$313 \pi T$ & Textlie mills and textile producc mills \\
$315 \mathrm{AL}$ & ADoparel and leather and dilied products
\end{tabular}

\begin{tabular}{l|l|l}
\hline $315 A L$ & Apparel and lea \\
\hline 321 & Wood products \\
\hline
\end{tabular}

\begin{tabular}{l|l}
322 & Paper products \\
\hline 323 & Printing and related support activities
\end{tabular}

Printing and related support activ
Petroleum and coal products

Chemical products
Plastics and rubber products

\begin{tabular}{l|l}
327 & Primary metals \\
\hline 332 & Fobrictod mal
\end{tabular}

\begin{tabular}{|l|l|}
\hline 332 & Fabricated metal products \\
\hline 333 & Machinery
\end{tabular}

\begin{tabular}{l|l}
334 & Computer and electronic products \\
\hline 335 & Electrical equilpment, appliancess, and componen
\end{tabular}

$\frac{3361 \mathrm{MV} \text { Motor vel }}{33640 \mathrm{~T} \text { Other tra }}$

\begin{tabular}{|l|l|}
\hline 337 & Furnitrun and and related equipmed prodts \\
\hline 339 & Miscellaneous manufacturing \\
\hline 32
\end{tabular}

\begin{tabular}{|l|l|l}
\hline 42 & Mscclanaeous mate \\
\hline $442 T$ & Wholesale trade \\
\hline 425
\end{tabular}

44RT

\begin{tabular}{ll}
\hline 482 & Rail transportation \\
\hline 483 & W transortation \\
\hline
\end{tabular}

\begin{tabular}{|l|l}
\hline 484 & Truck transportation \\
\hline 485 & Transit and ground passenger transportation \\
\hline
\end{tabular}

$486 \quad$ Pipeline transportation

\begin{tabular}{|l|l|}
\hline 493 & Warehousing and storage \\
\hline 511 & Publishing industries (includes software)
\end{tabular}

\begin{tabular}{ll}
\hline 512 & Mubilithing industries (includes sottware) \\
\hline 512 & Miture and sound recording industries
\end{tabular}

\begin{tabular}{l|l}
514 & Information and data processing services \\
\hline $521 \mathrm{CI}$ & Federal Reserve banks, credititintermediation, related activitie \\
\hline 523 & Securtios,
\end{tabular}

\begin{tabular}{l|l}
524 & Insurance, carriers and related, activities \\
\hline 525 & Funds, trusts, and other financial vehicles
\end{tabular}

\begin{tabular}{l|l}
531 & Real estate \\
\hline $532 \mathrm{RL}$ & Rental and leasing services and lessors of intangible assets \\
\hline
\end{tabular}

5411 Legal services

\begin{tabular}{|l|l|}
\hline 541200 & Miscellaneous professional, scientific and technical services \\
\hline 5415 & Computer systems design and related services \\
\hline 55 & Management of companies and enterprises \\
\hline
\end{tabular}

\begin{tabular}{|l|l}
561 & Administrative and support services \\
\hline 562 & Waste management and remediation services
\end{tabular}

\begin{tabular}{|l|l|}
\hline 621 & Ambulatory health care services \\
\hline $622 \mathrm{HO}$ & Hospitials and nursing and residential care facilities \\
\hline
\end{tabular}

$711 \mathrm{AS}$ Performing arts, spectator sports, museums, related activities

$713 \quad$ Amusements, gambling, and recreation industries

\begin{tabular}{l|l}
\hline 722 & Accommodation \\
\hline 722 & Food services and drinking places \\
\hline
\end{tabular}

\begin{tabular}{ll}
\hline GFE & Other services, except government \\
\hline GFG & Federal govermment tenterprises \\
\hline
\end{tabular}

GSLE State and local government enterprise

\begin{tabular}{l|l}
\hline GSLG & State and local general government \\
\hline S001 & Scrap, used and secondhand goods \\
\hline
\end{tabular}

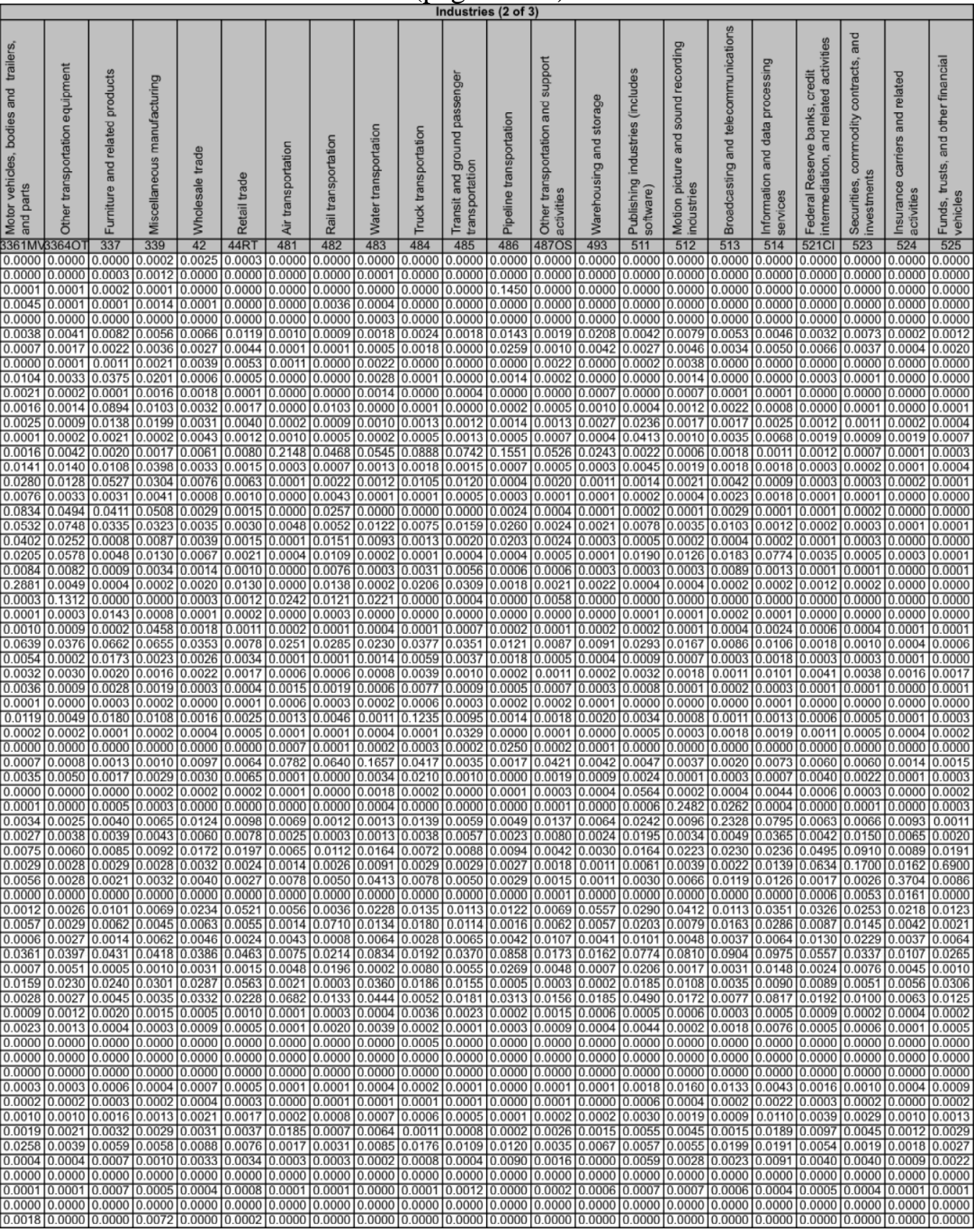

B-12 
Normalized Use Table continued (page 3 of 3)

Pub
Com
Code

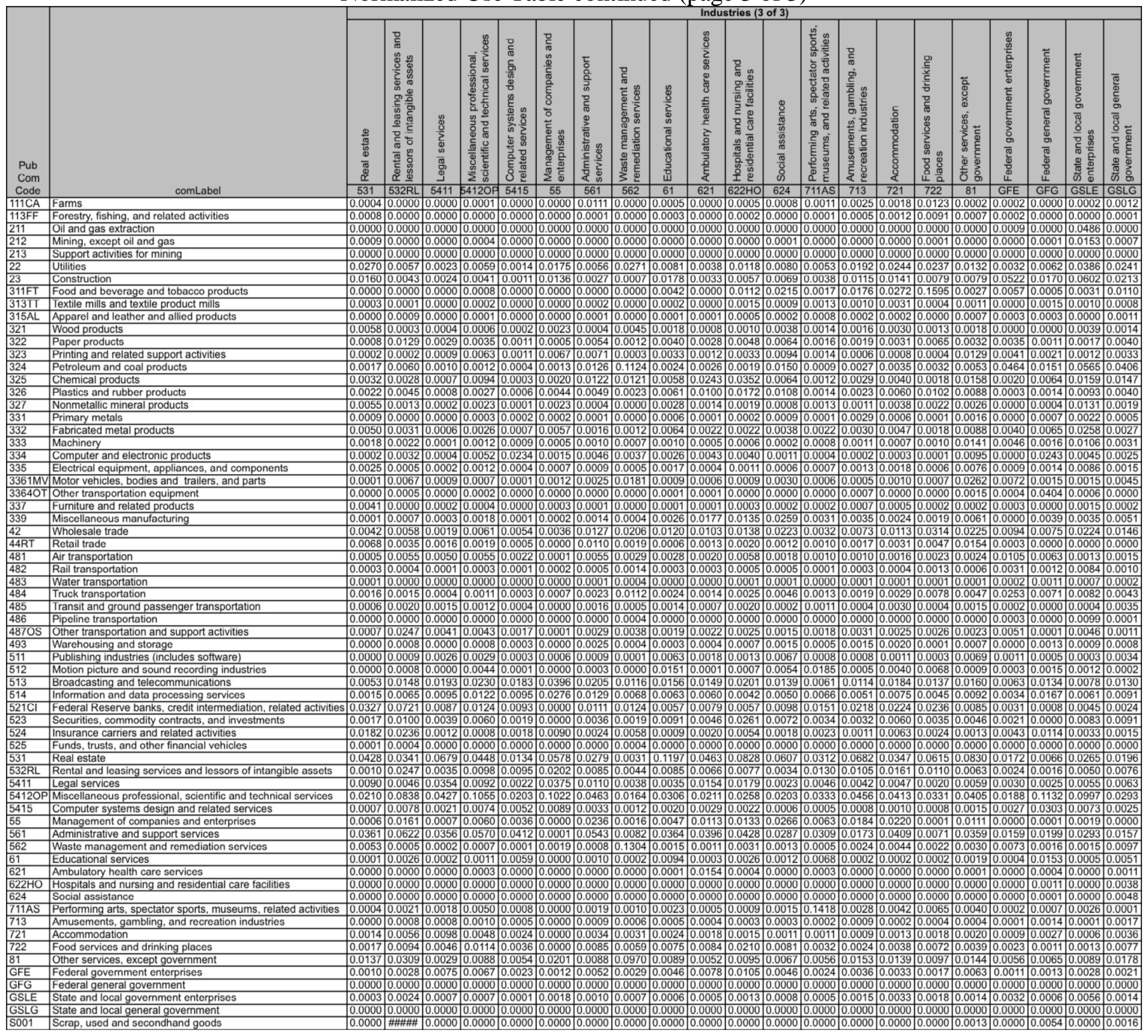

B-13 
Table B-5. Input-Output Model: Leontif industry-by-industry technical coefficient matrix, A (page 1 of 3)

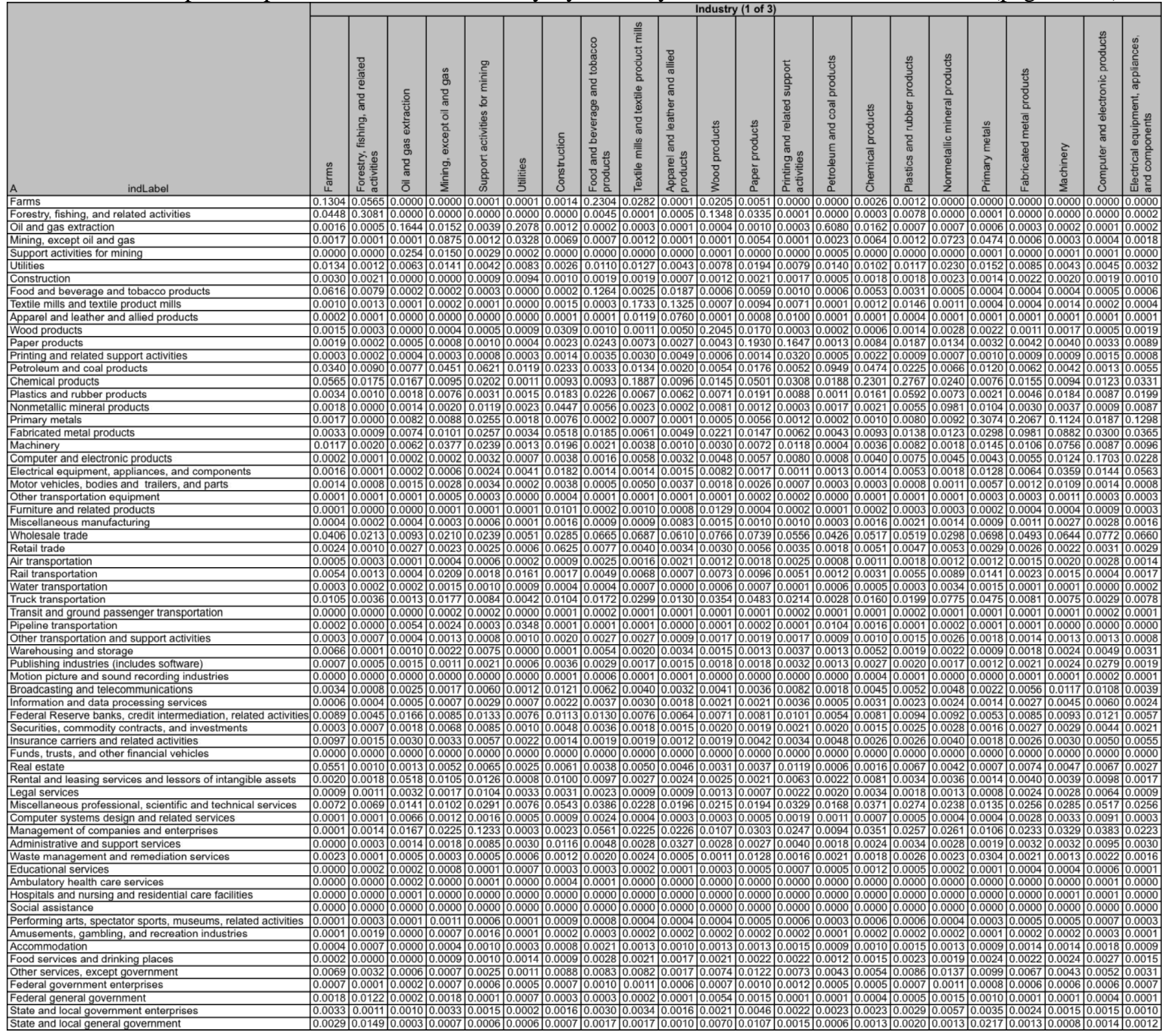


Input-Output Model: Leontif industry-by-industry technical coefficient matrix, $\mathbf{A}$ (page 2 of 3)

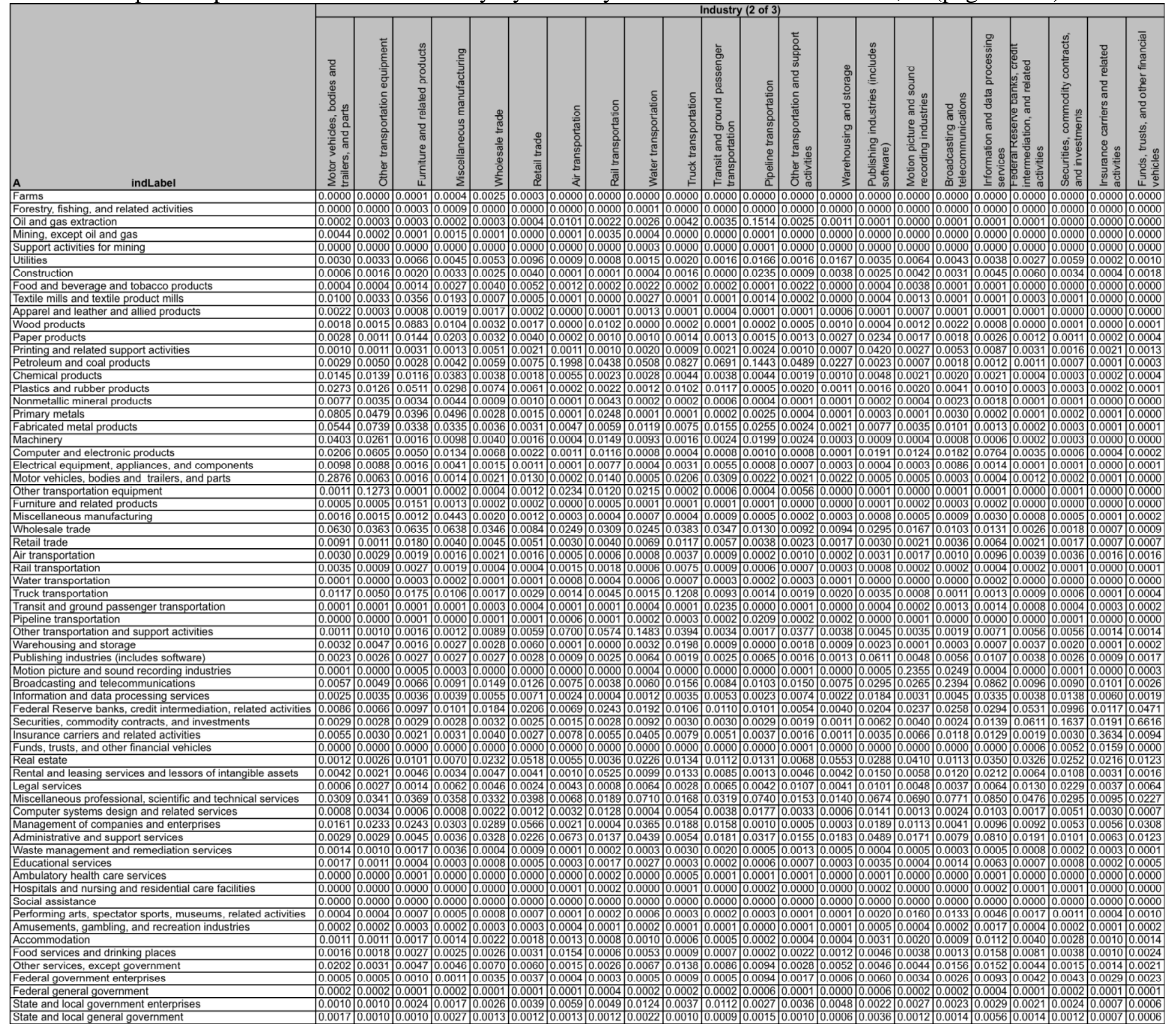

\section{B-15}


Input-Output Model: Leontif industry-by-industry technical coefficient matrix, $\mathbf{A}$ (page 3 of 3 )

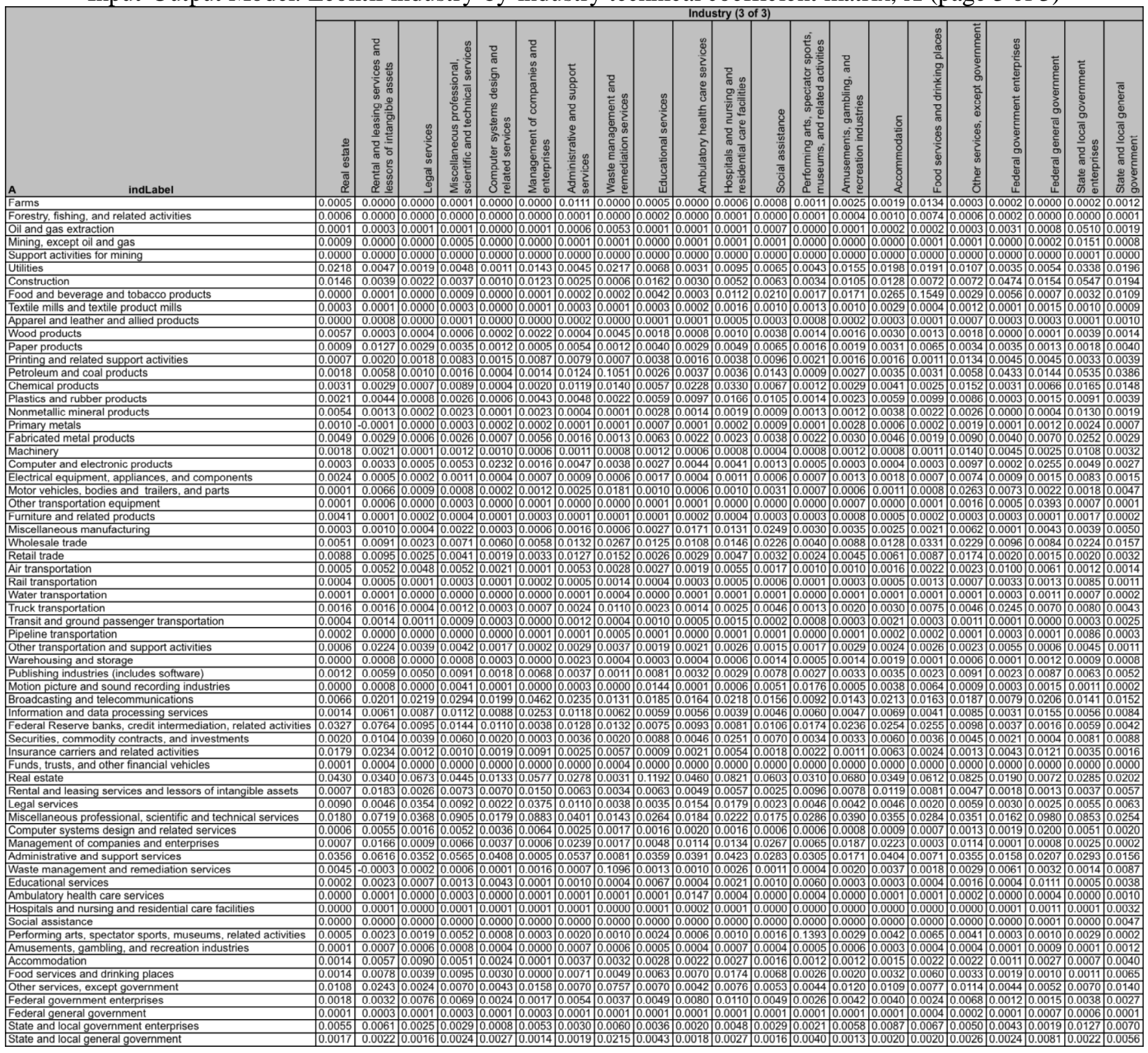

B-16 
Table B-6. Input-Output Model vectors Ax, $\mathbf{x}$, and $\mathbf{c}$

\begin{tabular}{|c|c|c|c|}
\hline indLabel & $\overline{A x}$ & $\bar{x}$ & c \\
\hline Farms & 10248825 & 19758371 & 9509546 \\
\hline Forestry, fishing, and related activities & 10710954 & 19512594 & 8801640 \\
\hline Oil and gas extraction & 25217916 & 19725380 & -5492537 \\
\hline Mining, except oil and gas & 5894184 & 19530516 & 13636332 \\
\hline Support activities for mining & 899311 & 19578786 & 18679475 \\
\hline Utilities & 10793383 & 19914878 & 9121495 \\
\hline Construction & 7178338 & 20697814 & 13519476 \\
\hline Food and beverage and tobacco products & 10441151 & 20163696 & 9722545 \\
\hline Textile mills and textile product mills & 8581864 & 19516607 & 10934744 \\
\hline Apparel and leather and allied products & 2285347 & 19482983 & 17197636 \\
\hline Wood products & 8593162 & 19550865 & 10957703 \\
\hline Paper products & 12426968 & 19617192 & 7190224 \\
\hline Printing and related support activities & 4697614 & 19552945 & 14855332 \\
\hline Petroleum and coal products & 28765143 & 20034077 & -8731066 \\
\hline Chemical products & 26945537 & 20094131 & -6851406 \\
\hline Plastics and rubber products & 10416172 & 19658935 & 9242763 \\
\hline Nonmetallic mineral products & 5831068 & 19569844 & 13738776 \\
\hline Primary metals & 22150456 & 19691597 & -2458859 \\
\hline Fabricated metal products & \begin{tabular}{|l|}
17678561 \\
\end{tabular} & 19773194 & 2094633 \\
\hline Machinery & 8946361 & 19773951 & 10827590 \\
\hline Computer and electronic products & 12381492 & 19838462 & 7456971 \\
\hline Electrical equipment, appliances, and compone & 5342792 & 19575563 & 14232771 \\
\hline Motor vehicles, bodies and trailers, and parts & \begin{tabular}{|l|l|}
10341951 \\
\end{tabular} & 19929614 & 9587663 \\
\hline Other transportation equipment & 4820621 & 19671114 & 14850493 \\
\hline Furniture and related products & 1186954 & 19531386 & 18344432 \\
\hline Miscellaneous manufacturing & 3758014 & 19606792 & 15848778 \\
\hline Whole & 36735813 & 20686416 & -16049397 \\
\hline Retail trade & 7051699 & 20831829 & 13780130 \\
\hline Air tran & 2782341 & 19601839 & 16819498 \\
\hline sportation & 3320142 & 19522097 & 16201955 \\
\hline Dortation & 433906 & 19487437 & 19053530 \\
\hline Truck transportation & 13886723 & 19725882 & 5839159 \\
\hline Transit and ground passenger transp & 970794 & 19482914 & 18512119 \\
\hline Pipeline transportation & 1797903 & 19485575 & 17687672 \\
\hline sportation and support activities & 10112529 & 19585716 & 9473186 \\
\hline and storage & 2582988 & 19502049 & 16919061 \\
\hline Iustries (includes software) & 5890591 & 19756204 & 13865614 \\
\hline and sound recording industries & 6350569 & 19550549 & 13199980 \\
\hline Broadcasting and telecommunications & 20744613 & 20250034 & -494579 \\
\hline processing services & 6916475 & 19636577 & 12720102 \\
\hline Federal Reserve banks, credit intermediati & 19874532 & 20214199 & 339667 \\
\hline Securities, commodity contracts, and inves & 22674187 & 19918938 & -2755249 \\
\hline Insurance carriers and related activities & 13735051 & 20119505 & 6384455 \\
\hline Ists, and other financial vehicles & 459475 & 19565041 & 19105566 \\
\hline Real estate & 30507410 & 21682569 & -8824841 \\
\hline Rental and leasing services and lessors of in & 9547895 & 19737557 & 10189662 \\
\hline Legal services & 7427421 & 19730980 & 12303559 \\
\hline Miscellaneous professional, scientific and technical s & 44859962 & 20552377 & -24307585 \\
\hline tems design and related services & 3894746 & 19667946 & 15773200 \\
\hline Management of companies and enterprises & 21408348 & 19899166 & -1509182 \\
\hline Administrative and support services & 24742630 & 20060653 & -4681977 \\
\hline Waste management and remediation services & 4847740 & 19526471 & 14678731 \\
\hline Educational services & 1572819 & 19666650 & 18093831 \\
\hline Ambulatory health care services & 423073 & 20180854 & 19757781 \\
\hline Hospitals and nursing and residential care facilities & 158783 & 20138209 & 19979426 \\
\hline Social assistance & 108566 & 19589175 & 19480609 \\
\hline Performing arts, spectator sports, museum & 4663349 & 19550569 & 14887220 \\
\hline Amusements, gambling, and recreation industries & 476042 & 19560084 & 19084042 \\
\hline Accommodation & 2403180 & 19651992 & 17248812 \\
\hline Food services and drinking places & 4376862 & 19967066 & 15590204 \\
\hline Other services, except government & 10405740 & 20051214 & 9645473 \\
\hline Federal government enterprises & 3302342 & 19552275 & 16249933 \\
\hline Federal general government & 744144 & 20320337 & 19576193 \\
\hline State and local government en & 4553602 & 19684700 & 15131098 \\
\hline State and local general governme & 3689097 & 21162095 & 17472998 \\
\hline
\end{tabular}


Table B-7. Inoperability Input-Output Model $\mathbf{A} *$ matrix (page 1 of 3 )

$\begin{array}{ll}A^{*} & \text { indlabel } \\ \text { Farms } & \end{array}$

Forestry, fishing, and related activities Mining, except oil and gas

\begin{tabular}{l} 
Utilities \\
\hline Construction \\
\hline Todiand
\end{tabular}

Food and beverage and tobacco product

Textile mills and textile product mills

Wood products

$\frac{}{\text { Printing and related support activities }}$

\begin{tabular}{|l|}
\hline Chemical products \\
\hline Plastics and rubber products \\
\hline
\end{tabular}

Frimaricated metals

Machinery
Computer and electronic products

Electrical equipement, appliancess, and components

Other transps,

\begin{tabular}{|l} 
Other transportation equipments \\
\hline Furniture and related products \\
\hline
\end{tabular}

Miscellaneous manufacturing

Wholesale trade

\begin{tabular}{l} 
Alir transportation \\
\hline Railtranspottition \\
\hline
\end{tabular}

\begin{tabular}{l} 
Rail transportation \\
Water transportation \\
\hline Thet thang
\end{tabular}

Transit and ground passenger transportation

\begin{tabular}{l} 
Pipeline transportation \\
\hline Other transportation and support activities
\end{tabular}

Warehousing and storage

Motion picture and sound recording industries

\begin{tabular}{l}
\hline Broadcasting and teleccommunications \\
\hline Information and data processing sorvices
\end{tabular}

Federal Reserve banks, credil intermediation, related activitie Securities, commodity contracts, and investmen

Insurance carriers and related activities

\begin{tabular}{ll}
\hline Real estate \\
\hline Rental and leasing services and lessors of intangible assets \\
\hline
\end{tabular} egal services Miscellaneous professional, scieienticic and technical services Managerement of companies and enterprises

Administrative and support services

Educational services

Hospitalts and nurrsing and residential care facilities
topila

Performing arts, spectator sports, museums, related activities Amusements, gambling, and recreation industries

\begin{tabular}{l} 
Accommodation \\
Food services and drinking places \\
\hline
\end{tabular}

\begin{tabular}{l}
\hline Other services, except government \\
\hline Federal government enterprises \\
\hline
\end{tabular}

\begin{tabular}{|l} 
Federal government enterprises \\
\hline Federal general government \\
\hline
\end{tabular}

\begin{tabular}{l} 
State and local government enterprises \\
\hline State and local general government \\
\hline
\end{tabular}

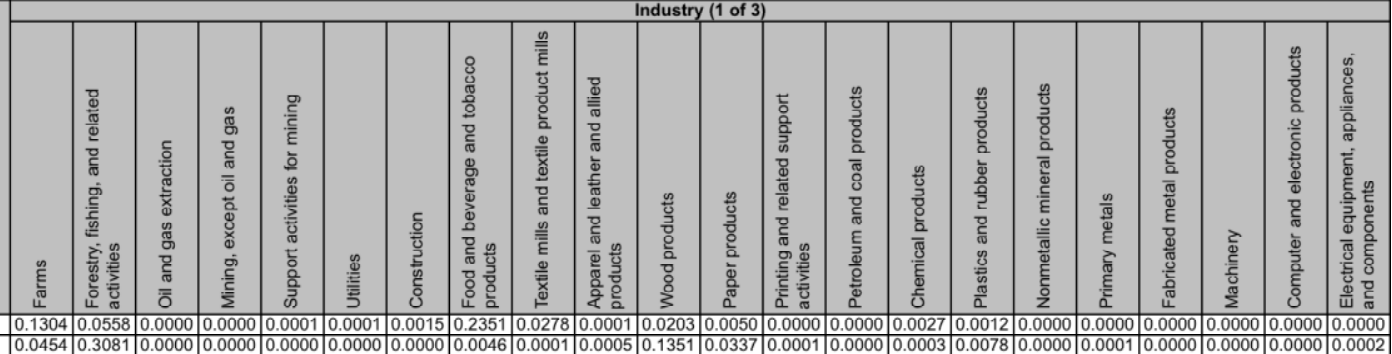

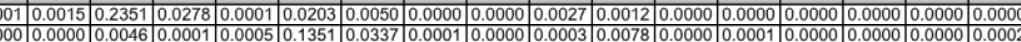

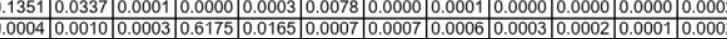

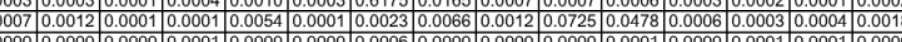

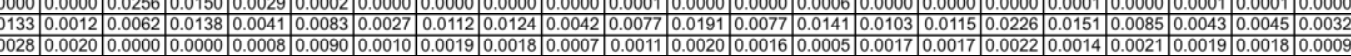

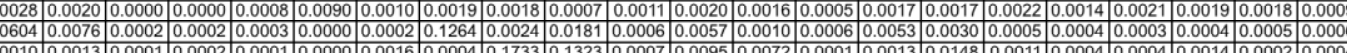

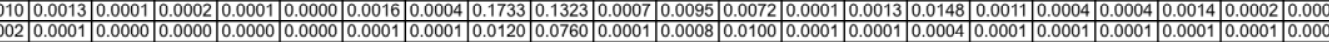

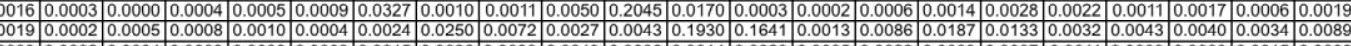

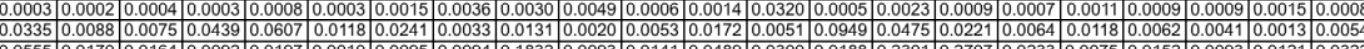

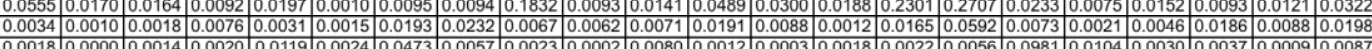

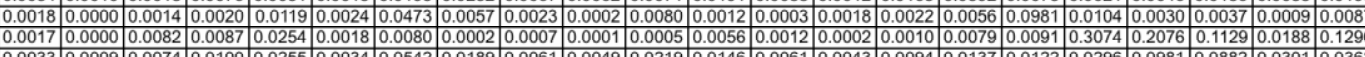

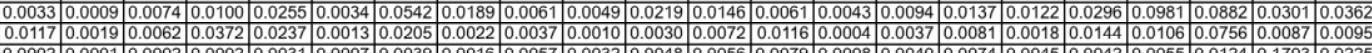

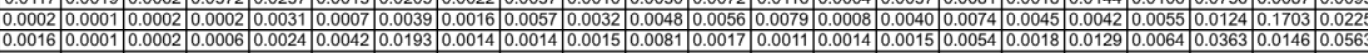

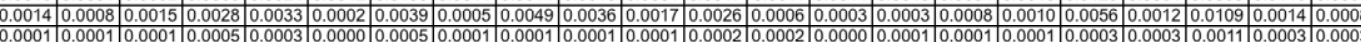

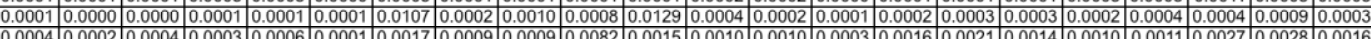

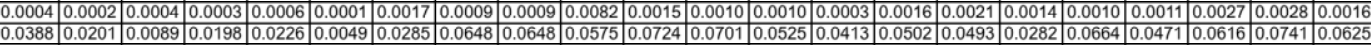

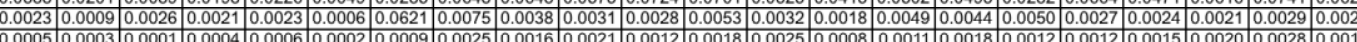

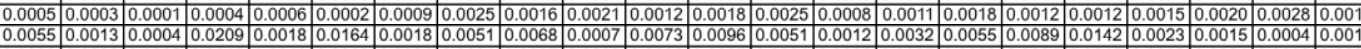

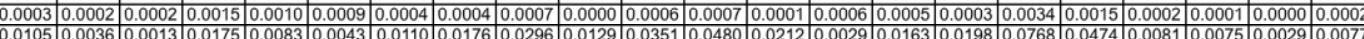

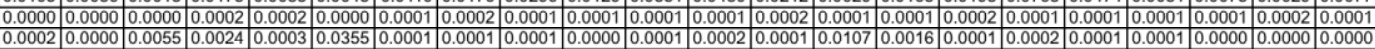

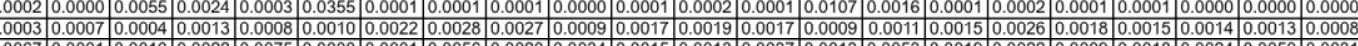

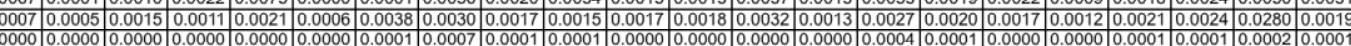

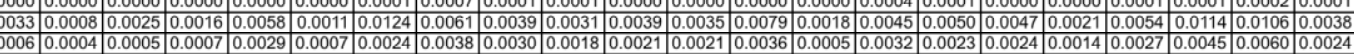

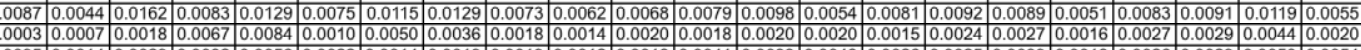

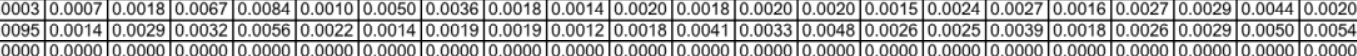

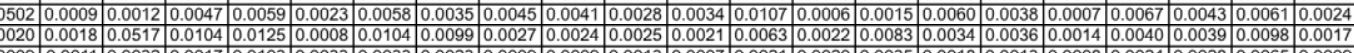

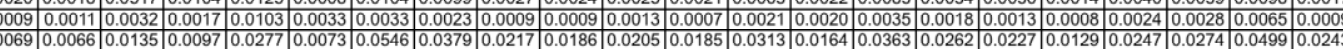

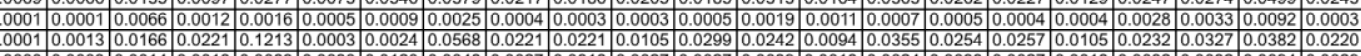

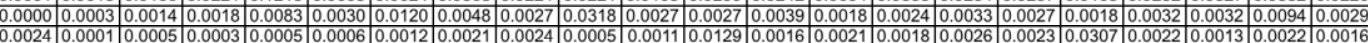

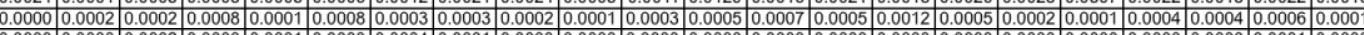

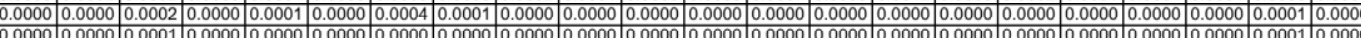

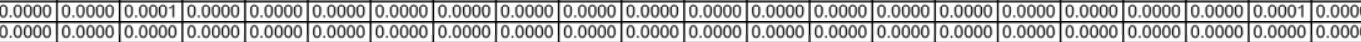

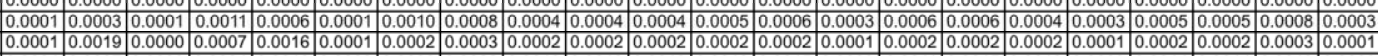

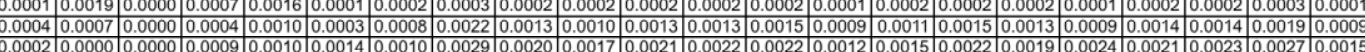

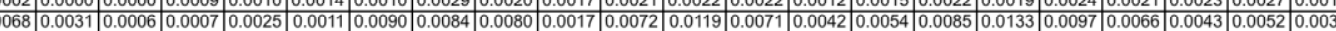

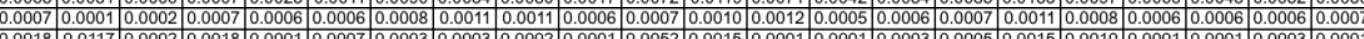

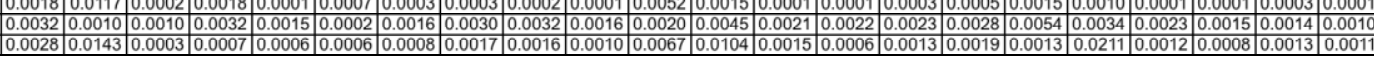


Inoperability Input-Output Model A* matrix (page 2 of 3)
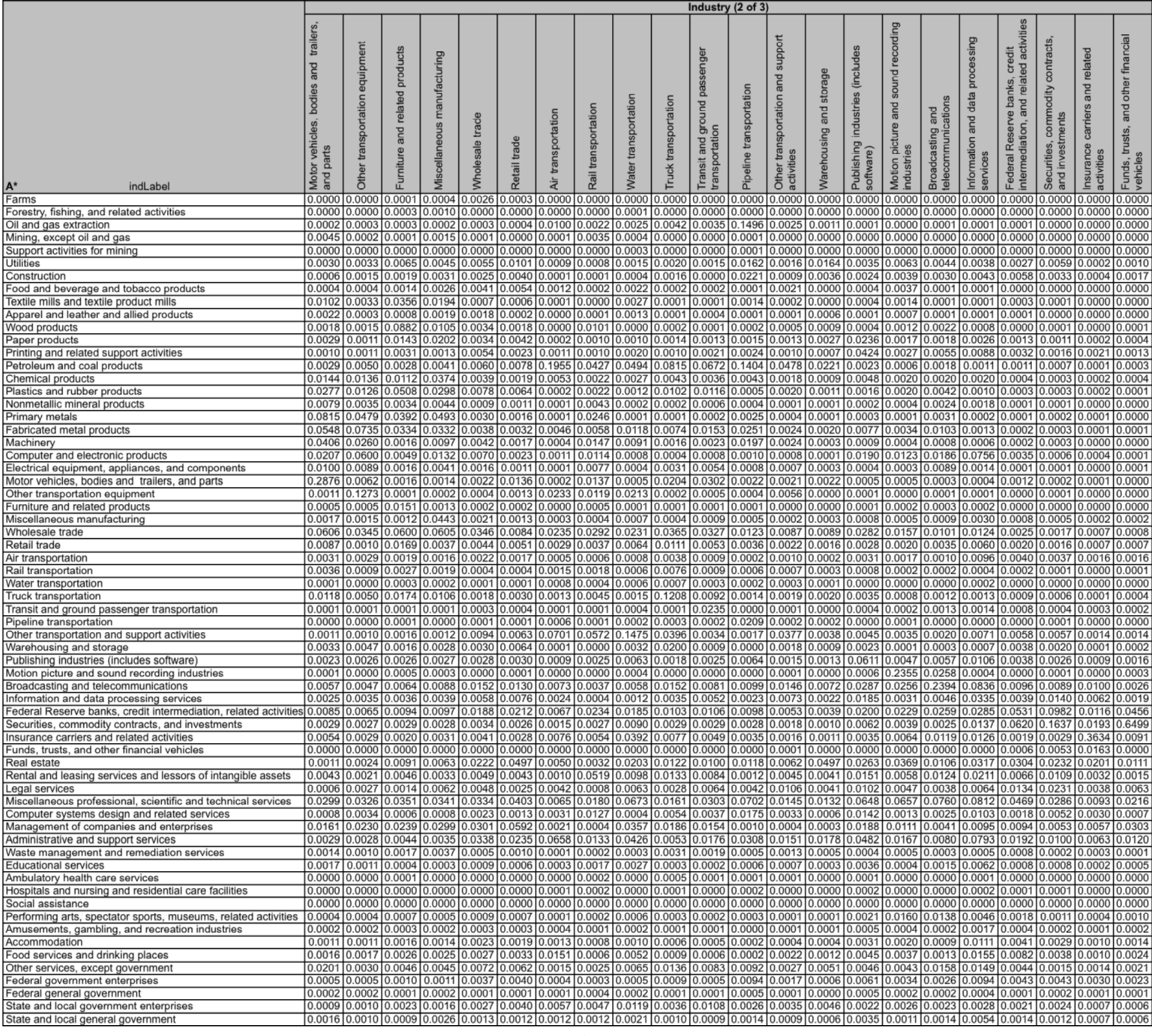

B-19 
Inoperability Input-Output Model A* matrix (page 3 of 3)

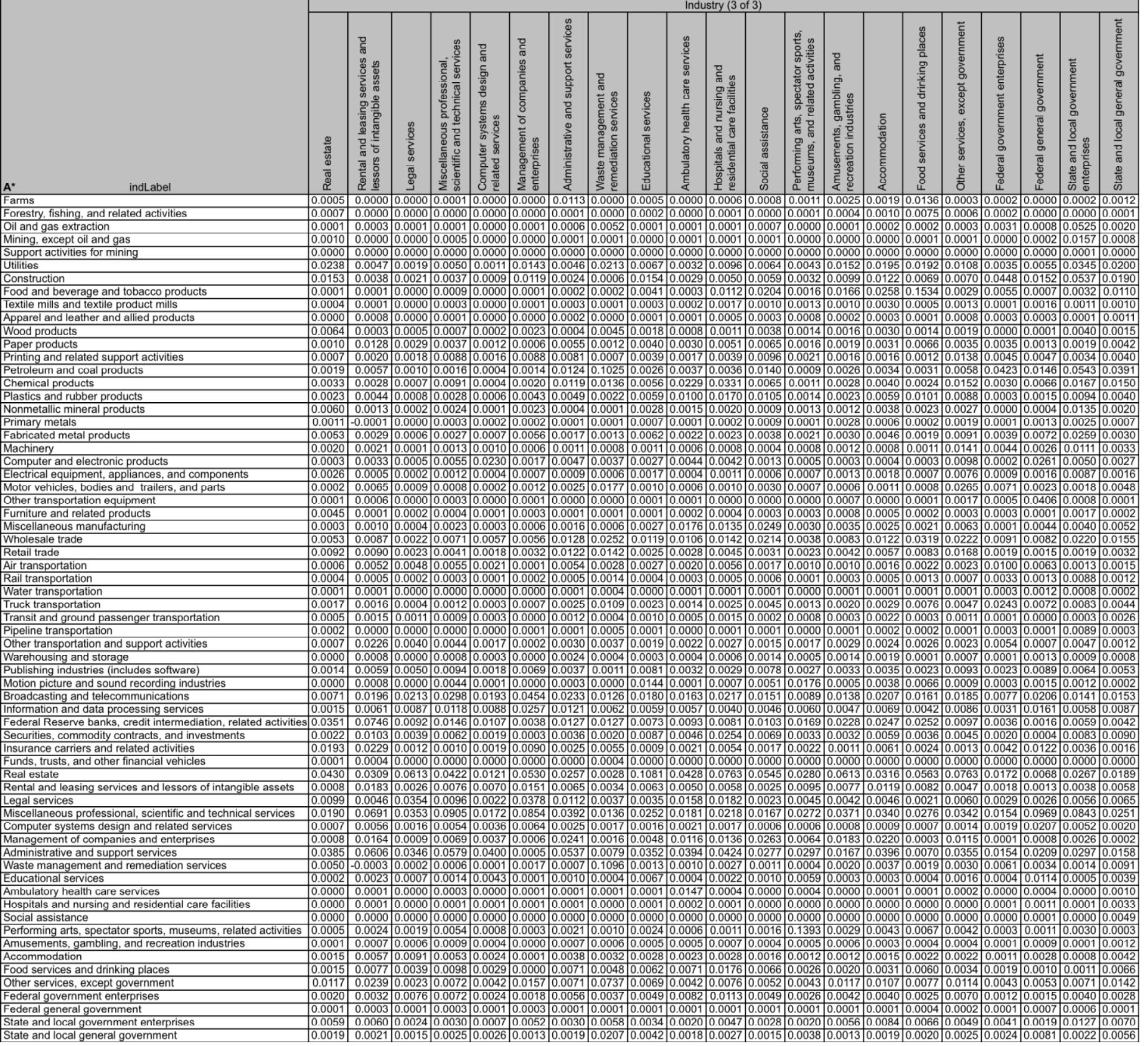


Table B-8. Inoperability Input-Output Model Results: Perturbation Vector, c*; Percent Disruption Vector, $\mathbf{q}$; and associated costs associated with the given disruption, $\$$

\begin{tabular}{|c|c|c|c|}
\hline IndLabel & $c^{*}$ & $\begin{array}{c}\mathbf{q} \text { (\% disruption, } \\
\text { ratio) }\end{array}$ & $\begin{array}{l}\$ \text { loss, } \\
\text { ratio }\end{array}$ \\
\hline Farms & 0 & $7.7676 \mathrm{E}-11$ & 0.0015 \\
\hline Forestry, fishing, and related activities & 0 & $6.0592 \mathrm{E}-11$ & 0.0012 \\
\hline Oil and gas extraction & 0 & $4.8269 \mathrm{E}-09$ & 0.0952 \\
\hline Mining, except oil and gas & 0 & 1.2547E-10 & 0.0025 \\
\hline Support activities for mining & 0 & $1.3108 \mathrm{E}-10$ & 0.0026 \\
\hline Utilities & 0 & 5.0173E-10 & 0.0100 \\
\hline Construction & 0 & $2.5237 \mathrm{E}-10$ & 0.0052 \\
\hline Food and beverage and tobacco products & 0 & $1.1544 \mathrm{E}-10$ & 0.0023 \\
\hline Textile mills and textile product mills & 0 & $7.6744 \mathrm{E}-11$ & 0.0015 \\
\hline Apparel and leather and allied products & 0 & $2.4134 \mathrm{E}-11$ & 0.0005 \\
\hline Wood products & 0 & 1.0873E-10 & 0.0021 \\
\hline Paper products & 0 & $3.2190 \mathrm{E}-10$ & 0.0063 \\
\hline Printing and related support activities & 0 & $2.0499 \mathrm{E}-10$ & 0.0040 \\
\hline Petroleum and coal products & 0 & $5.8366 \mathrm{E}-09$ & 0.1169 \\
\hline Chemical products & 0 & 1.1795E-09 & 0.0237 \\
\hline Plastics and rubber products & 0 & $8.7295 \mathrm{E}-10$ & 0.0172 \\
\hline Nonmetallic mineral products & 0 & 1.4184E-10 & 0.0028 \\
\hline Primary metals & 0 & $7.8366 \mathrm{E}-10$ & 0.0154 \\
\hline Fabricated metal products & 0 & $9.3231 \mathrm{E}-10$ & 0.0184 \\
\hline Machinery & 0 & $3.5353 \mathrm{E}-10$ & 0.0070 \\
\hline Computer and electronic products & 0 & $3.3492 \mathrm{E}-10$ & 0.0066 \\
\hline Electrical equipment, appliances, and components & 0 & $3.2915 \mathrm{E}-10$ & 0.0064 \\
\hline Motor vehicles, bodies and trailers, and parts & 0 & 1.8253E-09 & 0.0364 \\
\hline Other transportation equipment & 0 & $5.7354 \mathrm{E}-11$ & 0.0011 \\
\hline Furniture and related products & 0 & $2.4891 \mathrm{E}-11$ & 0.0005 \\
\hline Miscellaneous manufacturing & 0 & $8.0285 \mathrm{E}-11$ & 0.0016 \\
\hline Wholesale trade & 0 & $3.1940 \mathrm{E}-09$ & 0.0661 \\
\hline Retail trade & 0 & $8.4846 \mathrm{E}-10$ & 0.0177 \\
\hline Air transportation & 0 & $3.0462 \mathrm{E}-10$ & 0.0060 \\
\hline Rail transportation & 0 & $5.1107 \mathrm{E}-10$ & 0.0100 \\
\hline Water transportation & 0 & $5.3159 \mathrm{E}-11$ & 0.0010 \\
\hline Truck transportation & $-5.1 \mathrm{E}-08$ & $5.7932 \mathrm{E}-08$ & 1.1428 \\
\hline Transit and ground passenger transportation & 0 & $2.5775 \mathrm{E}-11$ & 0.0005 \\
\hline Pipeline transportation & 0 & $1.3278 \mathrm{E}-10$ & 0.0026 \\
\hline Other transportation and support activities & 0 & $2.5878 \mathrm{E}-09$ & 0.0507 \\
\hline Warehousing and storage & 0 & 1.2315E-09 & 0.0240 \\
\hline Publishing industries (includes software) & 0 & $2.7812 \mathrm{E}-10$ & 0.0055 \\
\hline Motion picture and sound recording industries & 0 & $8.9740 \mathrm{E}-11$ & 0.0018 \\
\hline Broadcasting and telecommunications & 0 & $1.8548 \mathrm{E}-09$ & 0.0376 \\
\hline Information and data processing services & 0 & $4.5234 \mathrm{E}-10$ & 0.0089 \\
\hline Federal Reserve banks, credit intermediation, and related activities & 0 & 1.3439E-09 & 0.0272 \\
\hline Securities, commodity contracts, and investments & 0 & 4.9904E-10 & 0.0099 \\
\hline Insurance carriers and related activities & 0 & 1.0524E-09 & 0.0212 \\
\hline Funds, trusts, and other financial vehicles & 0 & $2.1962 \mathrm{E}-11$ & 0.0004 \\
\hline Real estate & 0 & $1.5596 \mathrm{E}-09$ & 0.0338 \\
\hline Rental and leasing services and lessors of intangible assets & 0 & $1.2898 \mathrm{E}-09$ & 0.0255 \\
\hline Legal services & 0 & $4.5934 \mathrm{E}-10$ & 0.0091 \\
\hline Miscellaneous professional, scientific and technical services & 0 & $2.4985 \mathrm{E}-09$ & 0.0513 \\
\hline Computer systems design and related services & 0 & $4.5574 \mathrm{E}-10$ & 0.0090 \\
\hline Management of companies and enterprises & 0 & 1.6992E-09 & 0.0338 \\
\hline Administrative and support services & 0 & 1.1303E-09 & 0.0227 \\
\hline Waste management and remediation services & 0 & $2.9571 \mathrm{E}-10$ & 0.0058 \\
\hline Educational services & 0 & $5.9179 \mathrm{E}-11$ & 0.0012 \\
\hline Ambulatory health care services & 0 & $3.4692 \mathrm{E}-11$ & 0.0007 \\
\hline Hospitals and nursing and residential care facilities & 0 & 7.1117E-12 & 0.0001 \\
\hline Social assistance & 0 & $1.3836 \mathrm{E}-12$ & 0.0000 \\
\hline Performing arts, spectator sports, museums, and related acti & 0 & $1.0221 \mathrm{E}-10$ & 0.0020 \\
\hline Amusements, gambling, and recreation industries & 0 & $1.9676 \mathrm{E}-11$ & 0.0004 \\
\hline Accommodation & 0 & $1.1741 \mathrm{E}-10$ & 0.0023 \\
\hline Food services and drinking places & 0 & 1.8197E-10 & 0.0036 \\
\hline Other services, except government & 0 & $1.1374 \mathrm{E}-09$ & 0.0228 \\
\hline Federal government enterprises & 0 & $1.5874 \mathrm{E}-10$ & 0.0031 \\
\hline Federal general government & 0 & $2.0238 \mathrm{E}-11$ & 0.0004 \\
\hline State and local government enterprises & 0 & $3.4433 \mathrm{E}-10$ & 0.0068 \\
\hline State and local general government & 0 & $1.4460 \mathrm{E}-10$ & 0.0031 \\
\hline
\end{tabular}


Table B-9. Standard Classification of Transported Goods (SCTG) Commodities matched to Bureau of Economic Analysis (BEA) Industries; SCTG Commodities in bold are used in Concept Demonstration, BEA industries with italics were not matched in FAF documentation (Southworth, et al., 2011) (page 1 of 2)

\begin{tabular}{|c|c|c|c|c|}
\hline \multicolumn{2}{|c|}{ SCTG Commodity } & \multirow{2}{*}{\begin{tabular}{|l|} 
BEA Industry Labels \\
Farms
\end{tabular}} & \multirow{2}{*}{\begin{tabular}{|l|}
$\begin{array}{l}q(\% \text { distruption, } \\
\text { ratio) }\end{array}$ \\
$7.77 \mathrm{E}-11$ \\
\end{tabular}} & \multirow{2}{*}{$\begin{array}{l}\begin{array}{l}\text { \$loss, } \\
\text { ratio }\end{array} \\
0.00153\end{array}$} \\
\hline 1 & Live animals/fish & & & \\
\hline 1 & Live animals/fish & Food and beverage and tobacco products & 1.15E-10 & 0.00233 \\
\hline 1 & Live animals/fish & Forestry, fishing, and related activities & $6.06 \mathrm{E}-11$ & 0.00118 \\
\hline 2 & Cereal grains & Farms & $7.77 \mathrm{E}-11$ & 0.00153 \\
\hline 2 & Cereal grains & Food and beverage and tobacco products & 1.15E-10 & 0.00233 \\
\hline 3 & Other agricultural products & Farms & $7.77 \mathrm{E}-11$ & 0.00153 \\
\hline 3 & Other agricultural products & Food and beverage and tobacco products & $1.15 \mathrm{E}-10$ & 0.00233 \\
\hline 4 & Animal feed & Farms & $7.77 \mathrm{E}-11$ & 0.00153 \\
\hline 4 & Animal feed & Food and beverage and tobacco products & $1.15 \mathrm{E}-10$ & 0.00233 \\
\hline 5 & Meat/seafood & Farms & $7.77 \mathrm{E}-11$ & 0.00153 \\
\hline 5 & Meat/seafood & Food and beverage and tobacco products & $1.15 \mathrm{E}-10$ & 0.00233 \\
\hline 6 & Milled grain prods. & Farms & $7.77 \mathrm{E}-11$ & 0.00153 \\
\hline 6 & Milled grain prods. & Food and beverage and tobacco products & $1.15 \mathrm{E}-10$ & 0.00233 \\
\hline 7 & Other foodstuffs & Farms & $7.77 \mathrm{E}-11$ & 0.00153 \\
\hline 7 & Other foodstuffs & Food and beverage and tobacco products & $1.15 \mathrm{E}-10$ & 0.00233 \\
\hline 8 & Alcoholic beverages & Food and beverage and tobacco products & 1.15E-10 & 0.00233 \\
\hline 9 & Tobacco prods. & Food and beverage and tobacco products & $1.15 \mathrm{E}-10$ & 0.00233 \\
\hline 10 & Building stone & Mining, except oil and gas & $1.25 \mathrm{E}-10$ & 0.00245 \\
\hline 10 & Building stone & Support activities for mining & 1.31E-10 & 0.00257 \\
\hline 11 & Natural sands & Mining, except oil and gas & $1.25 \mathrm{E}-10$ & 0.00245 \\
\hline 11 & Natural sands & Support activities for mining & $1.31 \mathrm{E}-10$ & 0.00257 \\
\hline 12 & Gravel & Mining, except oil and gas & $1.25 \mathrm{E}-10$ & 0.00245 \\
\hline 12 & Gravel & Support activities for mining & $1.31 \mathrm{E}-10$ & 0.00257 \\
\hline 13 & Nonmetallic minerals & Mining, except oil and gas & $1.25 \mathrm{E}-10$ & 0.00245 \\
\hline 13 & Nonmetallic minerals & Support activities for mining & $1.31 \mathrm{E}-10$ & 0.00257 \\
\hline 14 & Metallic ores & Mining, except oil and gas & $1.25 \mathrm{E}-10$ & 0.00245 \\
\hline$\overline{14}$ & Metallic ores & Support activities for mining & $1.31 \mathrm{E}-10$ & 0.00257 \\
\hline 15 & Coal & Mining, except oil and gas & $1.25 \mathrm{E}-10$ & 0.00245 \\
\hline 15 & Coal & Petroleum and coal products & 5.84E-09 & 0.11693 \\
\hline 15 & Coal & Support activities for mining & $1.31 \mathrm{E}-10$ & 0.00257 \\
\hline 16 & Crude petroleum & Oil and gas extraction & $4.83 \mathrm{E}-09$ & 0.09521 \\
\hline 16 & Crude petroleum & Petroleum and coal products & 5.84E-09 & 0.11693 \\
\hline 17 & Gasoline & Oil and gas extraction & 4.83E-09 & 0.09521 \\
\hline 17 & Gasoline & Petroleum and coal products & $5.84 \mathrm{E}-09$ & 0.11693 \\
\hline 18 & Fuel oils & Oil and gas extraction & 4.83E-09 & 0.09521 \\
\hline 18 & Fuel oils & Petroleum and coal products & $5.84 \mathrm{E}-09$ & 0.11693 \\
\hline 19 & Coal-n.e.c. & Motor vehicles, bodies and trailers, and parts & 1.83E-09 & 0.03638 \\
\hline 19 & Coal-n.e.c. & Oil and gas extraction & $4.83 E-09$ & 0.09521 \\
\hline 19 & Coal-n.e.c. & Other transportation equipment & $5.74 \mathrm{E}-11$ & 0.00113 \\
\hline 19 & Coal-n.e.c. & Petroleum and coal products & 5.84E-09 & 0.11693 \\
\hline 20 & Basic chemicals & Chemical products & $1.18 \mathrm{E}-09$ & 0.02370 \\
\hline 21 & Pharmaceuticals & Chemical products & $1.18 \mathrm{E}-09$ & 0.02370 \\
\hline 22 & Fertilizers & Chemical products & 1.18E-09 & 0.02370 \\
\hline 23 & Chemical prods. & Chemical products & 1.18E-09 & 0.02370 \\
\hline 24 & Plastics/rubber & Chemical products & $1.18 \mathrm{E}-09$ & 0.02370 \\
\hline 24 & Plastics/rubber & Motor vehicles, bodies and trailers, and parts & $1.83 \mathrm{E}-09$ & 0.03638 \\
\hline 24 & Plastics/rubber & Other transportation equipment & 5.74E-11 & 0.00113 \\
\hline 24 & Plastics/rubber & Plastics and rubber products & $8.73 \mathrm{E}-10$ & 0.01716 \\
\hline 25 & Logs & Forestry, fishing, and related activities & $6.06 \mathrm{E}-11$ & 0.00118 \\
\hline 25 & Logs & Wood products & 1.09E-10 & 0.00213 \\
\hline 26 & Wood products & Furniture and related products & $2.49 \mathrm{E}-11$ & 0.00049 \\
\hline 26 & Wood products & Wood products & 1.09E-10 & 0.00213 \\
\hline 27 & Newsprint/paper & Paper products & $3.22 \mathrm{E}-10$ & 0.00631 \\
\hline 27 & Newsprint/paper & Publishing industries (includes software) & $2.78 \mathrm{E}-10$ & 0.00549 \\
\hline 27 & Newsprint/paper & Wood products & $1.09 \mathrm{E}-10$ & 0.00213 \\
\hline 28 & Paper articles & Paper products & $3.22 \mathrm{E}-10$ & 0.00631 \\
\hline 28 & Paper articles & Wood products & 1.09E-10 & 0.00213 \\
\hline 29 & Printed products & Printing and related support activities & $2.05 \mathrm{E}-10$ & 0.00401 \\
\hline 29 & Printed products & Publishing industries (includes software) & $2.78 \mathrm{E}-10$ & 0.00549 \\
\hline 30 & Textiles/leather & Apparel and leather and allied products & $2.41 \mathrm{E}-11$ & 0.00047 \\
\hline 30 & Textiles/leather & Furniture and related products & $2.49 \mathrm{E}-11$ & 0.00049 \\
\hline 30 & Textiles/leather & Textile mills and textile product mills & $7.67 \mathrm{E}-11$ & 0.00150 \\
\hline 31 & Nonmetal mineral products & Nonmetallic mineral products & $1.42 \mathrm{E}-10$ & 0.00278 \\
\hline
\end{tabular}


Standard Classification of Transported Goods (SCTG) Commodities matched to Bureau of Economic

Analysis (BEA) Industries; SCTG Commodities in bold are used in Concept Demonstration, BEA

industries with italics were not matched in FAF documentation (Southworth, et al., 2011) (page 2 of 2)

\begin{tabular}{|c|c|c|c|}
\hline SCTG Commodity & BEA Industry Labels & $\begin{array}{l}q(\% \text { distruption, } \\
\text { ratio) }\end{array}$ & $\begin{array}{l}\text { \$ loss, } \\
\text { ratio }\end{array}$ \\
\hline 32 Base metals & Fabricated metal products & $9.32 \mathrm{E}-10$ & 0.01843 \\
\hline 32 Base metals & Primary metals & $7.84 \mathrm{E}-10$ & 0.01543 \\
\hline 33 Articles-base metal & Fabricated metal products & $9.32 \mathrm{E}-10$ & 0.01843 \\
\hline 33 Articles-base metal & Primary metals & $7.84 \mathrm{E}-10$ & 0.01543 \\
\hline 34 Machinery & Electrical equipment, appliances, and components & $3.29 \mathrm{E}-10$ & 0.00644 \\
\hline 34 Machinery & Machinery & $3.54 \mathrm{E}-10$ & 0.00699 \\
\hline 35 Electronics & Computer and electronic products & $3.35 \mathrm{E}-10$ & 0.00664 \\
\hline 35 Electronics & Electrical equipment, appliances, and components & $3.29 \mathrm{E}-10$ & 0.00644 \\
\hline 35 Electronics & Machinery & $3.54 \mathrm{E}-10$ & 0.00699 \\
\hline 35 Electronics & Motion picture and sound recording industries & $8.97 \mathrm{E}-11$ & 0.00175 \\
\hline 35 Electronics & Motor vehicles, bodies and trailers, and parts & 1.83E-09 & 0.03638 \\
\hline 35 Electronics & Other transportation equipment & $5.74 \mathrm{E}-11$ & 0.00113 \\
\hline 35 Electronics & Publishing industries (includes software) & $2.78 \mathrm{E}-10$ & 0.00549 \\
\hline 36 Motorized vehicles & Motor vehicles, bodies and trailers, and parts & $1.83 \mathrm{E}-09$ & 0.03638 \\
\hline 36 Motorized vehicles & Other transportation equipment & 5.74E-11 & 0.00113 \\
\hline 37 Transport equipment & Motor vehicles, bodies and trailers, and parts & 1.83E-09 & 0.03638 \\
\hline 37 Transport equipment & Other transportation equipment & $5.74 \mathrm{E}-11$ & 0.00113 \\
\hline 38 Precision instruments & Computer and electronic products & $3.35 \mathrm{E}-10$ & 0.00664 \\
\hline 38 Precision instruments & Electrical equipment, appliances, and components & $3.29 \mathrm{E}-10$ & 0.00644 \\
\hline 38 Precision instruments & Fabricated metal products & $9.32 \mathrm{E}-10$ & 0.01843 \\
\hline 38 Precision instruments & Machinery & $3.54 \mathrm{E}-10$ & 0.00699 \\
\hline 39 Furniture & Furniture and related products & $2.49 \mathrm{E}-11$ & 0.00049 \\
\hline 39 Furniture & Wood products & $1.09 \mathrm{E}-10$ & 0.00213 \\
\hline 40 Misc. mfg. products. & Miscellaneous manufacturing & $8.03 \mathrm{E}-11$ & 0.00157 \\
\hline 41 Waste/scrap & Waste management and remediation services & $2.96 \mathrm{E}-10$ & 0.00577 \\
\hline (assume within county) & Construction & $2.52 \mathrm{E}-10$ & 0.00522 \\
\hline (assumed within county) & Retail trade & $8.48 \mathrm{E}-10$ & 0.01767 \\
\hline Multiple commodities & Warehousing and storage & 1.23E-09 & 0.02402 \\
\hline Multiple commodities & Wholesale trade & $3.19 \mathrm{E}-09$ & 0.06607 \\
\hline (Service Industry) & Accommodation & $1.17 \mathrm{E}-10$ & 0.00231 \\
\hline (Service Industry) & Administrative and support services & 1.13E-09 & 0.02267 \\
\hline (Service Industry) & Air transportation & $3.05 \mathrm{E}-10$ & 0.00597 \\
\hline (Service Industry) & Ambulatory health care services & $3.47 \mathrm{E}-11$ & 0.00070 \\
\hline (Service Industry) & Amusements, gambling, and recreation industries & 1.97E-11 & 0.00038 \\
\hline (Service Industry) & Broadcasting and telecommunications & 1.85E-09 & 0.03756 \\
\hline (Service Industry) & Computer systems design and related services & $4.56 \mathrm{E}-10$ & 0.00896 \\
\hline (Service Industry) & Educational services & $5.92 \mathrm{E}-11$ & 0.00116 \\
\hline (Service Industry) & Federal general government & $2.02 \mathrm{E}-11$ & 0.00041 \\
\hline (Service Industry) & Federal government enterprises & $1.59 \mathrm{E}-10$ & 0.00310 \\
\hline (Service Industry) & Federal Reserve banks, credit intermediation, and related activities & $1.34 \mathrm{E}-09$ & 0.02716 \\
\hline (Service Industry) & Food services and drinking places & $1.82 \mathrm{E}-10$ & 0.00363 \\
\hline (Service Industry) & Funds, trusts, and other financial vehicles & $2.20 \mathrm{E}-11$ & 0.00043 \\
\hline (Service Industry) & Hospitals and nursing and residential care facilities & $7.11 \mathrm{E}-12$ & 0.00014 \\
\hline (Service Industry) & Information and data processing services & $4.52 \mathrm{E}-10$ & 0.00888 \\
\hline (Service Industry) & Insurance carriers and related activities & $1.05 \mathrm{E}-09$ & 0.02117 \\
\hline (Service Industry) & Legal services & $4.59 \mathrm{E}-10$ & 0.00906 \\
\hline (Service Industry) & Management of companies and enterprises & $1.70 \mathrm{E}-09$ & 0.03381 \\
\hline (Service Industry) & Miscellaneous professional, scientific and technical services & $2.50 \mathrm{E}-09$ & 0.05135 \\
\hline (Service Industry) & Other services, except government & $1.14 \mathrm{E}-09$ & 0.02281 \\
\hline (Service Industry) & Other transportation and support activities & $2.59 \mathrm{E}-09$ & 0.05068 \\
\hline (Service Industry) & Performing arts, spectator sports, museums, and related activities & $1.02 \mathrm{E}-10$ & 0.00200 \\
\hline (Service Industry) & Pipeline transportation & $1.33 \mathrm{E}-10$ & 0.00259 \\
\hline (Service Industry) & Rail transportation & $5.11 \mathrm{E}-10$ & 0.00998 \\
\hline (Service Industry) & Real estate & $1.56 \mathrm{E}-09$ & 0.03382 \\
\hline (Service Industry) & Rental and leasing services and lessors of intangible assets & 1.29E-09 & 0.02546 \\
\hline (Service Industry) & Securities, commodity contracts, and investments & $4.99 \mathrm{E}-10$ & 0.00994 \\
\hline (Service Industry) & Social assistance & $1.38 \mathrm{E}-12$ & 0.00003 \\
\hline (Service Industry) & State and local general government & $1.45 \mathrm{E}-10$ & 0.00306 \\
\hline (Service Industry) & State and local government enterprises & $3.44 \mathrm{E}-10$ & 0.00678 \\
\hline (Service Industry) & Transit and ground passenger transportation & $2.58 \mathrm{E}-11$ & 0.00050 \\
\hline (Service Industry) & Truck transportation & $5.79 \mathrm{E}-08$ & 1.14275 \\
\hline (Service Industry) & Utilities & $5.02 \mathrm{E}-10$ & 0.00999 \\
\hline (Service Industry) & Water transportation & $5.32 \mathrm{E}-11$ & 0.00104 \\
\hline
\end{tabular}


Table B-10. Economic Hindrance by BEA Industry due to Calculated Mobility- and Safety-based Excess User Costs to the Trucking Sector for U.S. 460 and U.S. 29 Study Corridors (page 1 of 2)

\begin{tabular}{|c|c|c|c|c|c|}
\hline \multirow[b]{2}{*}{ BEA Industry Labels (Input-Output Model) } & \multirow{2}{*}{$\begin{array}{c}\text { BEA \$ } \\
\text { loss, } \\
\text { ratio } \\
\end{array}$} & \multicolumn{2}{|c|}{$\begin{array}{c}\text { U.S. } 460 \\
\text { Economic } \\
\text { Hindrance, } \$\end{array}$} & \multicolumn{2}{|c|}{$\begin{array}{c}\text { U.S. } 29 \\
\text { Economic } \\
\text { Hindrance, \$ }\end{array}$} \\
\hline & & Mobility & Safety & Mobility & Safety \\
\hline Truck transportation & 1.1428 & 7423 & 6195 & 307 & 1097 \\
\hline Petroleum and coal products & 0.1169 & 6080 & 5075 & 251 & 899 \\
\hline Oil and gas extraction & 0.0952 & 4951 & 4132 & 205 & 732 \\
\hline Wholesale trade & 0.0661 & 3436 & 2867 & 142 & 508 \\
\hline $\begin{array}{l}\text { Miscellaneous professional, scientific and technical } \\
\text { services }\end{array}$ & 0.0513 & 2670 & 2228 & 110 & 395 \\
\hline Other transportation and support activities & 0.0507 & 2636 & 2200 & 109 & 390 \\
\hline Broadcasting and telecommunications & 0.0376 & 1953 & 1630 & 81 & 289 \\
\hline Motor vehicles, bodies and trailers, and parts & 0.0364 & 1892 & 1579 & 78 & 280 \\
\hline Real estate & 0.0338 & 1758 & 1468 & 73 & 260 \\
\hline Management of companies and enterprises & 0.0338 & 1758 & 1467 & 73 & 260 \\
\hline $\begin{array}{l}\text { Federal Reserve banks, credit intermediation, and related } \\
\text { activities }\end{array}$ & 0.0272 & 1413 & 1179 & 58 & 209 \\
\hline Rental and leasing services and lessors of intangible assets & 0.0255 & 1324 & 1105 & 55 & 196 \\
\hline Warehousing and storage & 0.0240 & 1249 & 1042 & 52 & 185 \\
\hline Chemical products & 0.0237 & 1232 & 1029 & 51 & 182 \\
\hline Other services, except government & 0.0228 & 1186 & 990 & 49 & 175 \\
\hline Administrative and support services & 0.0227 & 1179 & 984 & 49 & 174 \\
\hline Insurance carriers and related activities & 0.0212 & 1101 & 919 & 46 & 163 \\
\hline Fabricated metal products & 0.0184 & 959 & 800 & 40 & 142 \\
\hline Retail trade & 0.0177 & 919 & 767 & 38 & 136 \\
\hline Plastics and rubber products & 0.0172 & 892 & 745 & 37 & 132 \\
\hline Primary metals & 0.0154 & 802 & 670 & 33 & 119 \\
\hline Utilities & 0.0100 & 520 & 434 & 21 & 77 \\
\hline Rail transportation & 0.0100 & 519 & 433 & 21 & 77 \\
\hline Securities, commodity contracts, and investments & 0.0099 & 517 & 431 & 21 & 76 \\
\hline Legal services & 0.0091 & 471 & 393 & 19 & 70 \\
\hline Computer systems design and related services & 0.0090 & 466 & 389 & 19 & 69 \\
\hline Information and data processing services & 0.0089 & 462 & 385 & 19 & 68 \\
\hline Machinery & 0.0070 & 364 & 303 & 15 & 54 \\
\hline State and local government enterprises & 0.0068 & 352 & 294 & 15 & 52 \\
\hline Computer and electronic products & 0.0066 & 346 & 288 & 14 & 51 \\
\hline Electrical equipment, appliances, and components & 0.0064 & 335 & 280 & 14 & 50 \\
\hline Paper products & 0.0063 & 328 & 274 & 14 & 49 \\
\hline Air transportation & 0.0060 & 310 & 259 & 13 & 46 \\
\hline Waste management and remediation services & 0.0058 & 300 & 251 & 12 & 44 \\
\hline Publishing industries (includes software) & 0.0055 & 286 & 238 & 12 & 42 \\
\hline Construction & 0.0052 & 272 & 227 & 11 & 40 \\
\hline
\end{tabular}




\begin{tabular}{|c|c|c|c|c|c|}
\hline \multirow[b]{2}{*}{ BEA Industry Labels (Input-Output Model) } & \multirow{2}{*}{$\begin{array}{c}\text { BEA \$ } \\
\text { loss, } \\
\text { ratio }\end{array}$} & \multicolumn{2}{|c|}{\begin{tabular}{|c|} 
U.S. 460 \\
Economic \\
Hindrance, \$
\end{tabular}} & \multicolumn{2}{|c|}{$\begin{array}{c}\text { U.S. } 29 \\
\text { Economic } \\
\text { Hindrance, \$ } \\
\end{array}$} \\
\hline & & & Safety & Mobility & Safety \\
\hline Printing and related support activities & 0.0040 & 208 & 174 & 9 & 31 \\
\hline Food services and drinking places & $\mid 0.0036$ & 189 & 158 & 8 & 28 \\
\hline Federal government enterprises & 0.0031 & 161 & 135 & 7 & 24 \\
\hline State and local general government & 0.0031 & 159 & 133 & 7 & 24 \\
\hline Nonmetallic mineral products & 0.0028 & 144 & 120 & 6 & 21 \\
\hline Pipeline transportation & 0.0026 & 135 & 112 & 6 & 20 \\
\hline Support activities for mining & 0.0026 & 133 & 111 & 6 & 20 \\
\hline Mining, except oil and gas & 0.0025 & 127 & 106 & 5 & 19 \\
\hline Food and beverage and tobacco products & 0.0023 & 121 & 101 & 5 & 18 \\
\hline Accommodation & 0.0023 & 120 & 100 & 5 & 18 \\
\hline Wood products & 0.0021 & 111 & 92 & 5 & 16 \\
\hline $\begin{array}{l}\text { Performing arts, spectator sports, museums, and related } \\
\text { activities }\end{array}$ & 0.0020 & 104 & 87 & 4 & 15 \\
\hline Motion picture and sound recording industries & 0.0018 & 91 & 76 & 4 & 13 \\
\hline Miscellaneous manufacturing & 0.0016 & 82 & 68 & 3 & 12 \\
\hline Farms & 0.0015 & 80 & 67 & 3 & 12 \\
\hline Textile mills and textile product mills & 0.0015 & 78 & 65 & 3 & 12 \\
\hline Forestry, fishing, and related activities & 0.0012 & 61 & 51 & 3 & 9 \\
\hline Educational services & 0.0012 & 61 & 51 & 3 & 9 \\
\hline Other transportation equipment & 0.0011 & 59 & 49 & 2 & 9 \\
\hline Water transportation & 0.0010 & 54 & 45 & 2 & 8 \\
\hline Ambulatory health care services & 0.0007 & 36 & 30 & 2 & 5 \\
\hline Transit and ground passenger transportation & 0.0005 & 26 & 22 & 1 & 4 \\
\hline Furniture and related products & 0.0005 & 25 & 21 & 1 & 4 \\
\hline Apparel and leather and allied products & 0.0005 & 24 & 20 & 1 & 4 \\
\hline Funds, trusts, and other financial vehicles & 0.0004 & 22 & 19 & 1 & 3 \\
\hline Federal general government & 0.0004 & 21 & 18 & 1 & 3 \\
\hline Amusements, gambling, and recreation industries & 0.0004 & 20 & 17 & 1 & 3 \\
\hline Hospitals and nursing and residential care facilities & 0.0001 & 7 & 6 & 0 & 1 \\
\hline Social assistance & 0.0000 & 1 & 1 & 0 & 0 \\
\hline & Total: & 55125 & 46005 & 2279 & 8149 \\
\hline
\end{tabular}




\section{APPENDIX C - CRASH DATA USED IN CONCEPT DEMONSTRATIONS}

TABLE C-1. U.S. 460 RAW TRUCK CRASH DATA FOR CONCEPT DEMONSTRATION STUDY

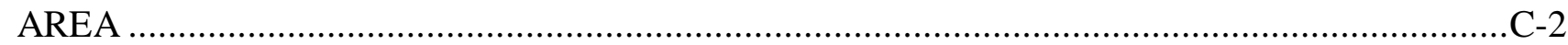

TABLE C-2. U.S. 29 RAW TRUCK CRASH DATA FOR CONCEPT DEMONSTRATION STUDY

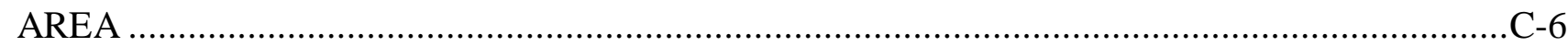

TABLE C-3. U.S. 460 FAF SEGMENTS AND AADTT FOR CONCEPT S DEMONSTRATION

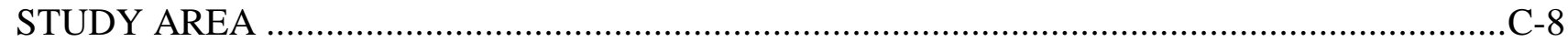


Table C-1. U.S. 460 Raw Truck Crash Data for Concept Demonstration Study Area (page 1 of 4)

\begin{tabular}{|c|c|c|c|c|c|c|}
\hline $\begin{array}{l}\text { CrashDocument } \\
\text { _CRASHDATE }\end{array}$ & $\begin{array}{l}\text { FATAL } \\
\text { COUNT }\end{array}$ & $\begin{array}{l}\text { INJURY } \\
\text { COUNT }\end{array}$ & $\begin{array}{l}\text { ROUTEMILE } \\
\text { POST }\end{array}$ & LATITUDE & LONGITUDE & $\begin{array}{l}\text { VEHICLE } \\
\text { TYPE }\end{array}$ \\
\hline 12-Oct-09 & 0 & 0 & 324.09 & 37.184165 & -77.319056 & 04 \\
\hline 03-Nov-06 & 0 & 0 & 324.12 & 0 & 0 & 04 \\
\hline 05-Jul-06 & 0 & 0 & 324.201 & 0 & 0 & 05 \\
\hline 07-Aug-09 & 0 & 1 & 324.24 & 37.183896 & -77.318637 & 23 \\
\hline $06-$ Oct-09 & 0 & 0 & 324.39 & 37.183715 & -77.318355 & 23 \\
\hline 08-Apr-09 & 0 & 0 & 324.39 & 37.182903 & -77.317094 & 23 \\
\hline 06-Jul-09 & 0 & 0 & 324.39 & 37.174785 & -77.30448 & 23 \\
\hline 01-Nov-10 & 1 & 1 & 324.39 & 37.174785 & -77.30448 & 04 \\
\hline 15-Jul-06 & 0 & 2 & 325.12 & 0 & 0 & 04 \\
\hline 15-Jul-06 & 0 & 2 & 325.12 & 0 & 0 & 04 \\
\hline 27-Mar-07 & 0 & 0 & 325.22 & 0 & 0 & 04 \\
\hline 27-Mar-07 & 0 & 0 & 325.22 & 0 & 0 & 05 \\
\hline 06-Мay-08 & 0 & 0 & 325.9 & 0 & 0 & 04 \\
\hline 02-Jun-05 & 0 & 0 & 326.05 & 0 & 0 & 05 \\
\hline 13-Jun-08 & 0 & 1 & 326.1 & 0 & 0 & 25 \\
\hline 26-Feb-06 & 0 & 0 & 326.3 & 0 & 0 & 05 \\
\hline 18-Мay-06 & 0 & 0 & 326.3 & 0 & 0 & 05 \\
\hline 13-Jul-06 & 0 & 1 & 326.3 & 0 & 0 & 05 \\
\hline 07-Feb-07 & 1 & 0 & 326.3 & 0 & 0 & 05 \\
\hline $06-F e b-07$ & 0 & 0 & 326.3 & 0 & 0 & 05 \\
\hline $06-F e b-07$ & 0 & 0 & 326.3 & 0 & 0 & 05 \\
\hline 01-Dec-10 & 1 & 3 & 326.47 & 37.165306 & -77.289761 & 23 \\
\hline 14-Jan-09 & 0 & 2 & 326.47 & 37.163 & -77.28763 & 23 \\
\hline 09-Sep-08 & 1 & 0 & 326.52 & 0 & 0 & 23 \\
\hline 17-Jun-07 & 0 & 1 & 326.55 & 0 & 0 & 04 \\
\hline 13 -Aug-05 & 0 & 0 & 327.025 & 0 & 0 & 05 \\
\hline 02-Apr-06 & 0 & 0 & 327.12 & 0 & 0 & 05 \\
\hline 13-Aug-08 & 0 & 1 & 327.12 & 0 & 0 & 23 \\
\hline 29-Dec-08 & 0 & 1 & 327.12 & 0 & 0 & 23 \\
\hline 17-Apr-07 & 0 & 1 & 327.129 & 0 & 0 & 05 \\
\hline 17-Apr-07 & 0 & 1 & 327.129 & 0 & 0 & 05 \\
\hline 17-Nov-05 & 0 & 1 & 327.148 & 0 & 0 & 05 \\
\hline 17-Nov-05 & 0 & 1 & 327.148 & 0 & 0 & 05 \\
\hline 10-Sep-10 & 0 & 0 & 327.29 & 37.159 & -77.28001 & 23 \\
\hline 12-Aug-09 & 0 & 0 & 327.29 & 37.156927 & -77.276788 & 23 \\
\hline 21-Dec-09 & 0 & 0 & 327.29 & 37.156023 & -77.275377 & 23 \\
\hline 11-Sep-09 & 0 & 1 & 327.29 & 37.156013 & -77.275361 & 23 \\
\hline 11-Sep-09 & 0 & 1 & 327.29 & 37.156013 & -77.275361 & 23 \\
\hline 11-Sep-09 & 0 & 1 & 327.29 & 37.156013 & -77.275361 & 23 \\
\hline $05-F e b-10$ & 0 & 1 & 327.29 & 37.15601 & -77.275356 & 23 \\
\hline 29-Jul-10 & 0 & 0 & 327.29 & 37.15599 & -77.27532 & 23 \\
\hline 23-Aug-09 & 0 & 1 & 327.29 & 37.151454 & -77.26835 & 23 \\
\hline 14-Jul-10 & 0 & 0 & 327.29 & 37.14236 & -77.25429 & 23 \\
\hline 29-Jan-09 & 0 & 2 & 327.29 & 37.09359 & -77.1652 & 23 \\
\hline 15-Aug-05 & 0 & 0 & 328.62 & 0 & 0 & 05 \\
\hline 03-Маy-06 & 0 & 2 & 329.39 & 0 & 0 & 05 \\
\hline 26-Oct-07 & 0 & 0 & 330.23 & 0 & 0 & 05 \\
\hline $18-F e b-05$ & 0 & 1 & 330.39 & 0 & 0 & 05 \\
\hline 27-Oct-05 & 0 & 0 & 330.39 & 0 & 0 & 05 \\
\hline 17-Feb-05 & 0 & 1 & 330.93 & 0 & 0 & 05 \\
\hline 27-Мay-05 & 0 & 0 & 331.08 & 0 & 0 & 05 \\
\hline 19-Apr-06 & 0 & 0 & 331.39 & 0 & 0 & 05 \\
\hline
\end{tabular}

C-2 


\begin{tabular}{|c|c|c|c|c|c|c|}
\hline $\begin{array}{l}\text { CrashDocument } \\
\text { CRASHDATE }\end{array}$ & $\begin{array}{l}\text { FATAL } \\
\text { COUNT }\end{array}$ & $\begin{array}{l}\text { INJURY } \\
\text { COUNT }\end{array}$ & $\begin{array}{l}\text { ROUTEMILE } \\
\text { POST }\end{array}$ & LATITUDE & LONGITUDE & $\begin{array}{c}\text { VEHICLE } \\
\text { TYPE }\end{array}$ \\
\hline 09-Aug-06 & 0 & 0 & 331.63 & 0 & 0 & 05 \\
\hline 27-Jul-07 & 0 & 2 & 332.58 & 0 & 0 & 05 \\
\hline 15-Мay-09 & 0 & 1 & 332.75 & 37.106641 & -77.198685 & 04 \\
\hline 13-Jun-06 & 1 & 0 & 332.88 & 0 & 0 & 04 \\
\hline 15-Dec-06 & 0 & 0 & 333.45 & 0 & 0 & 05 \\
\hline 24-Sep-09 & 0 & 0 & 333.49 & 37.097136 & -77.184328 & 23 \\
\hline 07-Apr-10 & 0 & 0 & 333.49 & 37.093242 & -77.17692 & 25 \\
\hline 06-Oct-10 & 1 & 1 & 333.49 & 37.093242 & -77.17692 & 23 \\
\hline 14-Sep-09 & 0 & 0 & 333.49 & 37.091828 & -77.173851 & 23 \\
\hline 01-Oct-08 & 0 & 0 & 334.6 & 0 & 0 & 23 \\
\hline 16-Jun-06 & 1 & 2 & 334.85 & 0 & 0 & 05 \\
\hline 22-Feb-07 & 0 & 1 & 335 & 0 & 0 & 05 \\
\hline 28-Jan-06 & 0 & 0 & 335.6 & 0 & 0 & 05 \\
\hline 07-Dec-10 & 0 & 1 & 335.77 & 37.08474 & -77.16252 & 23 \\
\hline 25-Jun-09 & 0 & 0 & 336.55 & 37.07231 & -77.14493 & 23 \\
\hline 13-Mar-07 & 0 & 3 & 336.6 & 0 & 0 & 05 \\
\hline 21-Jul-06 & 1 & 0 & 337.13 & 0 & 0 & 05 \\
\hline 28-Jun-06 & 0 & 1 & 337.3 & 0 & 0 & 05 \\
\hline 15-Apr-08 & 0 & 0 & 338.82 & 0 & 0 & 23 \\
\hline 11-Dec-08 & 0 & 0 & 339.22 & 0 & 0 & 05 \\
\hline 30-Jan-06 & 0 & 2 & 340 & 0 & 0 & 05 \\
\hline 29-Apr-05 & 0 & 0 & 340.07 & 0 & 0 & 05 \\
\hline 03-Dec-06 & 0 & 0 & 340.22 & 0 & 0 & 04 \\
\hline 05-Aug-07 & 0 & 0 & 340.22 & 0 & 0 & 05 \\
\hline $05-$ Oct-07 & 0 & 0 & 340.22 & 0 & 0 & 05 \\
\hline 15-Jun-09 & 0 & 0 & 340.39 & 0 & 0 & 23 \\
\hline 06-Aug-07 & 1 & 0 & 340.47 & 0 & 0 & 05 \\
\hline 25-Apr-05 & 0 & 0 & 340.94 & 0 & 0 & 05 \\
\hline 26-Jul-05 & 0 & 1 & 340.94 & 0 & 0 & 05 \\
\hline 18-Jun-07 & 1 & 1 & 341.44 & 0 & 0 & 05 \\
\hline 05-Jul-08 & 0 & 0 & 341.88 & 0 & 0 & 05 \\
\hline 08-Apr-09 & 0 & 0 & 342.55 & 37.016654 & -77.062665 & 23 \\
\hline 08-Jun-07 & 0 & 0 & 342.55 & 0 & 0 & 05 \\
\hline 08-Jun-07 & 0 & 0 & 342.55 & 0 & 0 & 04 \\
\hline 12-Nov-06 & 0 & 0 & 344.71 & 0 & 0 & 05 \\
\hline 05-Sep-06 & 0 & 0 & 345.91 & 0 & 0 & 05 \\
\hline 10-Aug-07 & 0 & 0 & 345.91 & 0 & 0 & 05 \\
\hline 10-Jun-09 & 0 & 0 & 346.6 & 36.985582 & -77.012274 & 25 \\
\hline 12-Feb-09 & 0 & 0 & 347.129 & 0 & 0 & 04 \\
\hline 27-Jul-05 & 0 & 0 & 347.36 & 0 & 0 & 05 \\
\hline 27-Dec-07 & 0 & 0 & 347.43 & 0 & 0 & 05 \\
\hline $25-$ Oct- 08 & 0 & 1 & 347.43 & 0 & 0 & 05 \\
\hline 29-Nov-07 & 0 & 0 & 347.54 & 0 & 0 & 05 \\
\hline 19-Aug-09 & 0 & 1 & 347.6 & 36.974149 & -76.989027 & 23 \\
\hline 23-Dec-09 & 0 & 0 & 347.71 & 36.973298 & -76.987297 & 25 \\
\hline 10-Mar-09 & 0 & 0 & 347.71 & 0 & 0 & 23 \\
\hline 18-Apr-07 & 0 & 2 & 347.79 & 0 & 0 & 05 \\
\hline 12-May-05 & 0 & 1 & 347.9 & 0 & 0 & 04 \\
\hline 29-Aug-05 & 0 & 0 & 347.9 & 0 & 0 & 05 \\
\hline 18-Nov-07 & 0 & 0 & 347.9 & 0 & 0 & 04 \\
\hline 10-Jun-08 & 0 & 1 & 347.9 & 0 & 0 & 05 \\
\hline 23 -Feb-08 & 0 & 1 & 347.909 & 0 & 0 & 05 \\
\hline 31-Oct-06 & 0 & 0 & 347.92 & 0 & 0 & 05 \\
\hline 19-Mar-07 & 0 & 1 & 347.944 & 0 & 0 & 05 \\
\hline 14-Jan-09 & 0 & 0 & 348.07 & 0 & 0 & 23 \\
\hline
\end{tabular}




\begin{tabular}{|c|c|c|c|c|c|c|}
\hline $\begin{array}{l}\text { CrashDocument } \\
\text { CRASHDATE }\end{array}$ & $\begin{array}{l}\text { FATAL } \\
\text { COUNT }\end{array}$ & $\begin{array}{l}\text { INJURY } \\
\text { COUNT }\end{array}$ & $\begin{array}{l}\text { ROUTEMILE } \\
\text { POST }\end{array}$ & LATITUDE & LONGITUDE & $\begin{array}{c}\text { VEHICLE } \\
\text { TYPE }\end{array}$ \\
\hline 19-Jun-09 & 0 & 0 & 348.07 & 0 & 0 & 23 \\
\hline 04-Nov-05 & 0 & 0 & 348.15 & 0 & 0 & 25 \\
\hline 27-Jan-10 & 0 & 0 & 348.233 & 36.96917 & -76.98142 & 04 \\
\hline 06-Dec-10 & 0 & 0 & 348.99 & 36.95902 & -76.9704 & 23 \\
\hline 04-Dec-06 & 0 & 0 & 349.32 & 0 & 0 & 05 \\
\hline 15-May-06 & 0 & 0 & 350.12 & 0 & 0 & 05 \\
\hline 12-Feb-10 & 0 & 1 & 350.25 & 36.948877 & -76.958006 & 23 \\
\hline 05-Jul-06 & 0 & 0 & 351.29 & 0 & 0 & 05 \\
\hline 09-Jul-08 & 0 & 0 & 351.29 & 0 & 0 & 05 \\
\hline 20-Aug-09 & 0 & 0 & 352.46 & 36.927125 & -76.924385 & 23 \\
\hline 22-Feb-06 & 0 & 1 & 352.87 & 0 & 0 & 05 \\
\hline 27-Jun-06 & 0 & 1 & 352.87 & 0 & 0 & 05 \\
\hline 27-Jun-06 & 0 & 1 & 352.87 & 0 & 0 & 05 \\
\hline 10-Sep-06 & 0 & 0 & 353.36 & 0 & 0 & 05 \\
\hline 16-Jul-07 & 0 & 0 & 353.61 & 0 & 0 & 05 \\
\hline 25-Sep-09 & 0 & 0 & 353.73 & 36.54867 & -76.54337 & 23 \\
\hline 11-Jan-09 & 0 & 1 & 354.03 & 36.5536 & -76.55058 & 23 \\
\hline 16-Мay-05 & 0 & 2 & 354.36 & 0 & 0 & 05 \\
\hline 06-Feb-07 & 0 & 0 & 354.6 & 0 & 0 & 06 \\
\hline 01-Dec-09 & 0 & 0 & 354.67 & 36.905544 & -76.891616 & 23 \\
\hline 04-Oct-06 & 0 & 1 & 355.45 & 0 & 0 & 05 \\
\hline 06-Nov-07 & 0 & 0 & 356.91 & 0 & 0 & 05 \\
\hline 25 -Oct-10 & 0 & 0 & 357.08 & 36.8858 & -76.8615 & 25 \\
\hline 20-Oct-09 & 0 & 0 & 357.08 & 36.884097 & -76.858889 & 23 \\
\hline 19-Nov-07 & 0 & 0 & 358.72 & 0 & 0 & 05 \\
\hline 15-Dec-10 & 0 & 0 & 358.85 & 36.86813 & -76.83453 & 04 \\
\hline 15-Dec-10 & 0 & 0 & 358.85 & 36.86813 & -76.83453 & 13 \\
\hline 16-Sep-05 & 0 & 1 & 358.85 & 0 & 0 & 05 \\
\hline 26-Sep-06 & 0 & 0 & 358.85 & 0 & 0 & 05 \\
\hline $25-F e b-09$ & 0 & 0 & 359.02 & 0 & 0 & 23 \\
\hline 22-Jun-05 & 0 & 1 & 359.258 & 0 & 0 & 05 \\
\hline 19-Мay-10 & 0 & 0 & 359.39 & 36.865539 & -76.827224 & 23 \\
\hline $05-$ Oct-07 & 0 & 0 & 359.97 & 0 & 0 & 04 \\
\hline 24-Jan-06 & 0 & 0 & 360.3 & 0 & 0 & 04 \\
\hline 13-May-08 & 0 & 0 & 360.3 & 0 & 0 & 05 \\
\hline 01-Mar-05 & 0 & 0 & 360.4 & 0 & 0 & 05 \\
\hline 13-Nov-06 & 0 & 0 & 360.4 & 0 & 0 & 05 \\
\hline 13-Nov-06 & 0 & 0 & 360.4 & 0 & 0 & 05 \\
\hline 25 -Oct-10 & 0 & 0 & 360.57 & 36.854332 & -76.813538 & 25 \\
\hline 21-Aug-08 & 1 & 2 & 361.3 & 0 & 0 & 05 \\
\hline 17-Feb-08 & 0 & 1 & 361.6 & 0 & 0 & 05 \\
\hline 22-Jul-10 & 0 & 0 & 361.92 & 36.839894 & -76.792237 & 04 \\
\hline 10-Mar-06 & 0 & 0 & 362.78 & 0 & 0 & 04 \\
\hline 06-Dec-07 & 0 & 2 & 363.86 & 0 & 0 & 05 \\
\hline 04-Sep-07 & 0 & 0 & 363.96 & 0 & 0 & 05 \\
\hline 06-Apr-10 & 0 & 0 & 364.13 & 36.820677 & -76.762968 & 23 \\
\hline 24-Jan-05 & 0 & 0 & 364.35 & 0 & 0 & 04 \\
\hline 18-Jan-06 & 0 & 0 & 364.83 & 0 & 0 & 05 \\
\hline 26-Aug-06 & 0 & 0 & 364.83 & 0 & 0 & 05 \\
\hline 26-Aug-06 & 0 & 0 & 364.83 & 0 & 0 & 05 \\
\hline 12-Aug-05 & 0 & 0 & 364.85 & 0 & 0 & 05 \\
\hline $15-$ Nov-05 & 0 & 1 & 364.85 & 0 & 0 & 23 \\
\hline 27-Apr-05 & 0 & 0 & 364.97 & 0 & 0 & 04 \\
\hline $18-$ Sep-10 & 0 & 0 & 365.02 & 36.81259 & -76.7507 & 23 \\
\hline 13-Jan-06 & 0 & 2 & 365.05 & 0 & 0 & 05 \\
\hline
\end{tabular}




\begin{tabular}{|c|c|c|c|c|c|c|}
\hline $\begin{array}{l}\text { CrashDocument } \\
\text { CRASHDATE }\end{array}$ & $\begin{array}{l}\text { FATAL } \\
\text { COUNT }\end{array}$ & $\begin{array}{l}\text { INJURY } \\
\text { COUNT }\end{array}$ & $\begin{array}{l}\text { ROUTEMILE } \\
\text { POST }\end{array}$ & LATITUDE & LONGITUDE & $\begin{array}{l}\text { VEHICLE } \\
\text { TYPE }\end{array}$ \\
\hline 08-Nov-06 & 0 & $\overline{0}$ & 365.3 & 0 & 0 & 05 \\
\hline 01-Feb-08 & 0 & 1 & 366.86 & 0 & 0 & 25 \\
\hline 15-Feb-08 & 0 & 1 & 366.86 & 0 & 0 & 05 \\
\hline 19-Dec-05 & 0 & 1 & 367.55 & 0 & 0 & 05 \\
\hline 16-Aug-07 & 1 & 0 & 367.55 & 0 & 0 & 05 \\
\hline 07-Feb-06 & 0 & 0 & 367.65 & 0 & 0 & 04 \\
\hline 01-Apr-09 & 0 & 0 & 367.72 & 0 & 0 & 25 \\
\hline 12-Aug-05 & 0 & 1 & 367.75 & 0 & 0 & 04 \\
\hline 09-Dec-09 & 0 & 0 & 367.82 & 36.799383 & -76.705698 & 23 \\
\hline 11-Jan-07 & 0 & 0 & 367.86 & 0 & 0 & 13 \\
\hline 11-Aug-09 & 0 & 0 & 368.02 & 36.47801 & -76.41558 & 23 \\
\hline 16-Feb-09 & 0 & 1 & 368.49 & 0 & 0 & 04 \\
\hline 19-Маy-08 & 1 & 0 & 368.52 & 0 & 0 & 04 \\
\hline $30-$ Oct-06 & 0 & 1 & 368.63 & 0 & 0 & 04 \\
\hline 05-Jan-09 & 0 & 1 & 368.69 & 36.79588 & -76.68885 & 25 \\
\hline 30-Sep-09 & 0 & 0 & 368.79 & 36.47724 & -76.41228 & 25 \\
\hline 30-Sep-09 & 0 & 0 & 368.79 & 36.47724 & -76.41228 & 25 \\
\hline 06-Dec-05 & 0 & 0 & 369.05 & 0 & 0 & 23 \\
\hline 21-Мay-05 & 3 & 3 & 369.55 & 0 & 0 & 05 \\
\hline 12-May-06 & 0 & 0 & 369.65 & 0 & 0 & 04 \\
\hline 12-May-06 & 0 & 0 & 369.65 & 0 & 0 & 05 \\
\hline 06-Nov-09 & 0 & 0 & 369.82 & 36.791015 & -76.667177 & 23 \\
\hline 16-Apr-07 & 0 & 0 & 369.85 & 0 & 0 & 23 \\
\hline 05-Nov-09 & 0 & 1 & 370.37 & 36.789385 & -76.659658 & 25 \\
\hline 13-Feb-08 & 0 & 0 & 370.45 & 0 & 0 & 05 \\
\hline 27-Jan-05 & 0 & 0 & 370.71 & 0 & 0 & 05 \\
\hline 13-Mar-06 & 0 & 0 & 370.96 & 0 & 0 & 05 \\
\hline 30-Mar-07 & 0 & 4 & 371.14 & 0 & 0 & 13 \\
\hline 15-Feb-06 & 0 & 0 & 371.4 & 0 & 0 & 25 \\
\hline 10-Mar-08 & 0 & 0 & 371.66 & 0 & 0 & 25 \\
\hline 18 -Oct-06 & 0 & 0 & 371.71 & 0 & 0 & 05 \\
\hline 27-Feb-08 & 1 & 0 & 371.71 & 0 & 0 & 23 \\
\hline 16-Маy-05 & 0 & 0 & 371.805 & 0 & 0 & 05 \\
\hline 15-Jul-09 & 0 & 0 & 371.88 & 36.78375 & -76.63319 & 23 \\
\hline 01-Aug-07 & 0 & 0 & 372.25 & 0 & 0 & 05 \\
\hline $17-$ Dec-07 & 0 & 1 & 372.25 & 0 & 0 & 05 \\
\hline 28-Feb-07 & 0 & 0 & 372.93 & 0 & 0 & 05 \\
\hline 18-Jul-05 & 0 & 0 & 372.94 & 0 & 0 & 06 \\
\hline 10-Nov-06 & 0 & 0 & 372.94 & 0 & 0 & 05 \\
\hline 11-Feb-08 & 0 & 0 & 372.98 & 0 & 0 & 23 \\
\hline $11-F e b-08$ & 0 & 0 & 372.98 & 0 & 0 & 23 \\
\hline 22-Nov-06 & 0 & 2 & 373.14 & 0 & 0 & 23 \\
\hline 14-Jul-06 & 0 & 1 & 373.38 & 0 & 0 & 05 \\
\hline 10-May-05 & 0 & 0 & 373.55 & 0 & 0 & 25 \\
\hline 19-Jan-06 & 0 & 0 & 373.62 & 0 & 0 & 05 \\
\hline 26-Jul-05 & 0 & 0 & 373.66 & 0 & 0 & 04 \\
\hline 15-Nov-06 & 1 & 0 & 373.66 & 0 & 0 & 05 \\
\hline 06-Aug-09 & 0 & 0 & 373.871 & 36.513084 & -76.171431 & 14 \\
\hline 05-Jun-09 & 0 & 0 & 373.881 & 0 & 0 & 14 \\
\hline 30-Jun-09 & 0 & 0 & 373.89 & 36.767225 & -76.603681 & 13 \\
\hline
\end{tabular}


Table C-2. U.S. 29 Raw Truck Crash Data for Concept Demonstration Study Area (page 1 of 2)

\begin{tabular}{|c|c|c|c|c|c|c|}
\hline $\begin{array}{l}\text { CrashDocument } \\
\text { _CRASHDATE }\end{array}$ & $\begin{array}{l}\text { FATAL } \\
\text { COUNT }\end{array}$ & $\begin{array}{l}\text { INJURY } \\
\text { COUNT }\end{array}$ & $\begin{array}{l}\text { ROUTEMILE } \\
\text { POST }\end{array}$ & LATITUDE & LONGITUDE & $\begin{array}{c}\text { VEHICLE } \\
\text { TYPE }\end{array}$ \\
\hline 17-Apr-09 & 0 & 0 & 139.404 & 38.058546 & -78.494523 & 23 \\
\hline 11-Sep-10 & 0 & 0 & 139.412 & 38.058651 & -78.494441 & 23 \\
\hline 06-Jul-10 & 0 & 3 & 139.42 & 38.05875 & -78.49436 & 23 \\
\hline 15-Nov-05 & 0 & 0 & 139.46 & 0 & 0 & 05 \\
\hline 15-Nov- 05 & 0 & 0 & 139.46 & 0 & 0 & 05 \\
\hline 18-Sep-06 & 0 & 0 & 139.46 & 0 & 0 & 05 \\
\hline 27-Nov-06 & 0 & 0 & 139.46 & 0 & 0 & 05 \\
\hline 16-Dec-08 & 0 & 1 & 139.474 & 0 & 0 & 04 \\
\hline 28-Sep-10 & 0 & 0 & 139.522 & 38.05993 & -78.493448 & 23 \\
\hline 19-Aug-10 & 0 & 0 & 139.551 & 38.0601 & -78.492972 & 23 \\
\hline 20-May-10 & 0 & 0 & 139.609 & 38.06075 & -78.492472 & 23 \\
\hline 05-Oct-07 & 0 & 0 & 139.676 & 0 & 0 & 04 \\
\hline 05-Mar-05 & 0 & 1 & 139.68 & 0 & 0 & 06 \\
\hline 02-Nov-06 & 0 & 0 & 139.68 & 0 & 0 & 04 \\
\hline 17-Jul-08 & 0 & 0 & 139.68 & 0 & 0 & 05 \\
\hline 18-Мау-10 & 0 & 1 & 139.69 & 38.061656 & -78.491775 & 04 \\
\hline 10-Nov-09 & 0 & 0 & 139.71 & 38.06216 & -78.491685 & 04 \\
\hline 04-Jun-09 & 0 & 0 & 139.711 & 38.061891 & -78.491578 & 23 \\
\hline 22-Dec-10 & 0 & 0 & 139.711 & 38.062173 & -78.491673 & 25 \\
\hline 27-Jul-10 & 0 & 0 & 139.723 & 38.0623 & -78.49154 & 23 \\
\hline 10-Jul-09 & 0 & 3 & 139.778 & 38.062935 & -78.49096 & 04 \\
\hline 26-Sep-09 & 0 & 0 & 139.814 & 38.063129 & -78.490464 & 04 \\
\hline 26-Mar-10 & 0 & 0 & 139.886 & 38.064014 & -78.489677 & 14 \\
\hline $22-$ Nov-10 & 0 & 0 & 139.932 & 38.064722 & -78.489336 & 04 \\
\hline 19-Aug-09 & 0 & 0 & 140.012 & 38.065526 & -78.488322 & 23 \\
\hline 22-Mar-06 & 0 & 0 & 140.05 & 0 & 0 & 04 \\
\hline 17-Jan-08 & 0 & 0 & 140.05 & 0 & 0 & 05 \\
\hline 25-Jun-08 & 0 & 0 & 140.088 & 0 & 0 & 23 \\
\hline 19-Dec-05 & 0 & 0 & 140.25 & 0 & 0 & 04 \\
\hline 20-Jun-05 & 0 & 1 & 140.38 & 0 & 0 & 04 \\
\hline 16-Jul-05 & 0 & 0 & 140.38 & 0 & 0 & 05 \\
\hline 16-Jul-05 & 0 & 0 & 140.38 & 0 & 0 & 04 \\
\hline 09-Jul-07 & 0 & 0 & 140.399 & 0 & 0 & 05 \\
\hline 01-Jul-10 & 0 & 0 & 140.4 & 38.070006 & -78.48429 & 04 \\
\hline $05-O c t-10$ & 0 & 0 & 140.4 & 38.0701 & -78.48451 & 23 \\
\hline 31-Mar-10 & 0 & 0 & 140.401 & 38.070018 & -78.484298 & 04 \\
\hline 01-Nov-10 & 0 & 0 & 140.401 & 38.07002 & -78.48429 & 25 \\
\hline 01-Dec-10 & 0 & 0 & 140.523 & 38.071479 & -78.483289 & 04 \\
\hline 23-Мау-07 & 0 & 0 & 140.62 & 0 & 0 & 04 \\
\hline 15-Jan-08 & 0 & 2 & 140.62 & 0 & 0 & 04 \\
\hline 13-Jul-07 & 0 & 0 & 140.64 & 0 & 0 & 23 \\
\hline 23-Nov-09 & 0 & 0 & 140.729 & 38.073934 & -78.480789 & 04 \\
\hline 18-Aug-05 & 0 & 0 & 140.86 & 0 & 0 & 05 \\
\hline 10-Aug-06 & 0 & 0 & 140.86 & 0 & 0 & 04 \\
\hline 12-Маy-07 & 0 & 0 & 140.86 & 0 & 0 & 05 \\
\hline 20-Jun-07 & 0 & 0 & 140.86 & 0 & 0 & 05 \\
\hline 18-Jan-08 & 0 & 0 & 140.861 & 0 & 0 & 04 \\
\hline 09-Nov-09 & 0 & 0 & 140.931 & 38.076174 & -78.478782 & 23 \\
\hline 05-Mar-10 & 0 & 0 & 140.961 & 38.076525 & -78.478458 & 04 \\
\hline 23-Oct-09 & 0 & 0 & 141.018 & 38.077228 & -78.477838 & 04 \\
\hline 10-Jun-06 & 0 & 0 & 141.031 & 0 & 0 & 05 \\
\hline 16-Jun-05 & 0 & 0 & 141.05 & 0 & 0 & 04 \\
\hline 30-Mar-06 & 0 & 1 & 141.05 & 0 & 0 & 05 \\
\hline 16-Aug-06 & 0 & 1 & 141.05 & 0 & 0 & 05 \\
\hline
\end{tabular}




\begin{tabular}{|c|c|c|c|c|c|c|}
\hline $\begin{array}{l}\text { CrashDocument } \\
\text { _CRASHDATE }\end{array}$ & $\begin{array}{l}\text { FATAL } \\
\text { COUNT }\end{array}$ & $\begin{array}{l}\text { INJURY } \\
\text { COUNT }\end{array}$ & $\begin{array}{l}\text { ROUTEMILE } \\
\text { POST }\end{array}$ & LATITUDE & LONGITUDE & $\begin{array}{l}\text { VEHICLE } \\
\text { TYPE }\end{array}$ \\
\hline 09-Feb-08 & 0 & 0 & 141.05 & 0 & 0 & 05 \\
\hline 01-Apr-05 & 0 & 1 & 141.14 & 0 & 0 & 05 \\
\hline 27-Aug-07 & 0 & 0 & 141.2 & 0 & 0 & 04 \\
\hline 04-Jan-06 & 0 & 0 & 141.206 & 0 & 0 & 05 \\
\hline 11-Dec-06 & 0 & 1 & 141.335 & 0 & 0 & 04 \\
\hline 11-Dec-06 & 0 & 1 & 141.335 & 0 & 0 & 05 \\
\hline 17-Aug-09 & 0 & 1 & 141.4 & 38.081923 & -78.473947 & 23 \\
\hline 29-Oct-10 & 0 & 0 & 141.404 & 38.08198 & -78.473932 & 13 \\
\hline 04-Oct-09 & 0 & 0 & 141.405 & 38.081745 & -78.473785 & 04 \\
\hline 24-Apr-07 & 0 & 0 & 141.406 & 0 & 0 & 04 \\
\hline 05-Nov-10 & 0 & 0 & 141.406 & 38.081781 & -78.473815 & 04 \\
\hline 26-Jan-10 & 0 & 0 & 141.406 & 38.082001 & -78.473917 & 23 \\
\hline $02-F e b-06$ & 0 & 0 & 141.425 & 0 & 0 & 05 \\
\hline 23-Jan-10 & 0 & 0 & 141.473 & 38.082791 & -78.473398 & 13 \\
\hline 03-May-05 & 0 & 0 & 141.52 & 0 & 0 & 05 \\
\hline 16-Jun-05 & 0 & 0 & 141.52 & 0 & 0 & 04 \\
\hline 01-Jul-05 & 0 & 0 & 141.52 & 0 & 0 & 05 \\
\hline 13-Jul-05 & 0 & 4 & 141.52 & 0 & 0 & 04 \\
\hline 17-Jan-07 & 0 & 2 & 141.52 & 0 & 0 & 23 \\
\hline 11-Mar-10 & 0 & 0 & 141.548 & 38.08371 & -78.472872 & 25 \\
\hline 04-Dec-10 & 0 & 1 & 141.596 & 38.08434 & -78.472512 & 04 \\
\hline 04-May-09 & 0 & 0 & 141.658 & 38.085144 & -78.472052 & 23 \\
\hline 14-May-07 & 0 & 0 & 141.7 & 0 & 0 & 23 \\
\hline 15-Sep-05 & 0 & 1 & 141.72 & 0 & 0 & 05 \\
\hline 25-Nov-08 & 0 & 0 & 141.85 & 0 & 0 & 05 \\
\hline 29-Jul-09 & 0 & 0 & 141.87 & 38.087915 & -78.470466 & 08 \\
\hline 10-Jun-09 & 0 & 0 & 141.889 & 0 & 0 & 23 \\
\hline 06-Маy-05 & 0 & 1 & 142.22 & 0 & $\overline{0}$ & 05 \\
\hline 19-Dec-05 & 0 & 0 & 142.22 & 0 & 0 & 05 \\
\hline 09-Dec-05 & 0 & 3 & 142.239 & 0 & 0 & 04 \\
\hline 05-Nov-09 & 0 & 1 & 142.57 & 38.097106 & -78.464623 & 04 \\
\hline 21 -Oct-10 & 0 & 0 & 142.64 & 38.0979 & -78.46399 & 25 \\
\hline 21 -Oct-10 & 0 & 0 & 142.64 & 38.0979 & -78.46399 & 25 \\
\hline 02-Oct-08 & 0 & 0 & 142.691 & 0 & 0 & 04 \\
\hline $14-$ Oct-05 & 0 & 2 & 142.7 & 0 & $\overline{0}$ & 05 \\
\hline 15-Apr-07 & 0 & 0 & 142.7 & 0 & $\overline{0}$ & 04 \\
\hline 17-Sep-07 & 0 & 0 & 142.7 & 0 & 0 & 04 \\
\hline 31-Mar-08 & 0 & 0 & 142.7 & 0 & 0 & 05 \\
\hline 31-Mar-08 & 0 & 0 & 142.7 & 0 & 0 & 04 \\
\hline 31-Mar-08 & 0 & 0 & 142.7 & 0 & 0 & 04 \\
\hline 07-Nov-08 & 0 & 0 & 142.7 & 0 & 0 & 04 \\
\hline 24-Feb-06 & 0 & 0 & 142.9 & 0 & 0 & 04 \\
\hline 25-Apr-08 & 0 & 1 & 142.9 & 0 & 0 & 06 \\
\hline 14-Oct-06 & 0 & 1 & 143.28 & 0 & 0 & 25 \\
\hline 17-Nov-10 & 0 & 0 & 143.417 & 38.107195 & -78.45686 & 04 \\
\hline 19-Dec-08 & 0 & 0 & & 38.06057 & -78.49294 & 14 \\
\hline 12-Aug-08 & 0 & 0 & & 38.06544 & -78.48835 & 23 \\
\hline 12-Aug-08 & 0 & 0 & & 38.06544 & -78.48835 & 23 \\
\hline 15-Nov-08 & 0 & 0 & & 38.07832 & -78.47682 & 04 \\
\hline 01-Aug-08 & 0 & 0 & & 38.08698 & -78.47106 & 04 \\
\hline
\end{tabular}


Table C-3. U.S. 460 FAF Segments and AADTT for Concept Demonstration Study Area

\begin{tabular}{|c|c|c|c|c|c|}
\hline \multicolumn{2}{|c|}{ Raw FAF Data } & \multirow{2}{*}{$\begin{array}{c}\text { Segment } \\
\text { Truck } \\
\text { DVMT }\end{array}$} & \multicolumn{3}{|c|}{$\begin{array}{c}\text { Consolidated Segments by } \\
\text { AADTT }\end{array}$} \\
\hline $\begin{array}{l}\text { Segment } \\
\text { Mileage }\end{array}$ & $\begin{array}{c}2007 \\
\text { AADTT }\end{array}$ & & Mileage & $\begin{array}{c}2007 \\
\text { AADTT }\end{array}$ & $\begin{array}{c}\text { Truck } \\
\text { DVMT }\end{array}$ \\
\hline 3.1 & 1918 & 5974 & \multirow{2}{*}{3.6} & \multirow{2}{*}{1918} & \multirow{2}{*}{6930} \\
\hline 0.5 & 1918 & 956 & & & \\
\hline 9.9 & 2012 & 19947 & \multirow{4}{*}{24.6} & \multirow{4}{*}{2012} & \multirow{4}{*}{49496} \\
\hline 6.2 & 2012 & 12407 & & & \\
\hline 8.4 & 2012 & 16858 & & & \\
\hline 0.1 & 2012 & 284 & & & \\
\hline 6.3 & 2271 & 14217 & \multirow{2}{*}{13.0} & \multirow{2}{*}{2271} & \multirow{2}{*}{29630} \\
\hline 6.8 & 2271 & 15413 & & & \\
\hline 3.8 & 3744 & 14130 & \multirow{4}{*}{8.8} & \multirow{4}{*}{3744} & \multirow{4}{*}{32964} \\
\hline 3.4 & 3744 & 12916 & & & \\
\hline 1.4 & 3744 & 5172 & & & \\
\hline 0.2 & 3744 & 745 & & & \\
\hline Total: & - & 119020 & 50.1 & - & 119020 \\
\hline Wtd. Average: & 2377 & - & - & 2377 & - \\
\hline
\end{tabular}

